|

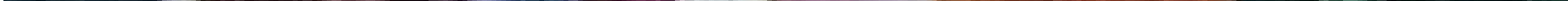




\section{O espaço de doméstico na cidade de São Paulo:} um projeto arquitetônico

\section{Dissertação de mestrado}

Faculdade de Arquitetura e Urbanismo da Universidade de São Paulo

Área de concentração: História e Fundamentos da Arquitetura e Urbanismo

Paulo V. Bruna

Orientador

São Paulo

março de 2009 
Dedico este trabalho aos que me ensinaram a paixão pela arquitetura, mas que já se foram: Meu pai, Nicola Viola e meu professor, Joaquim Guedes.

E ainda o dedico ao arquiteto Massimiliano Fuksas, que me deu a oportunidade de iniciar-me profissionalmente, quando colaborei com seu trabalho por três anos. 
Agradeço a todos os que me deram a oportunidade de aprender e exercer minha profissão; em especial a Ivone Viola, minha mãe; a minhas irmãs, Ana, Angela e Alessandra, pela enorme paciência e ao meu irmão Arturo, pela paciência e também pelas traduções; aos colegas diversos por todos os lugares em que estive; e, na CDHU, especialmente a Lucila Soares, a Marilisa Targas e a Renato Daud.

Agradeço ao Professor Paulo Bruna, pela paciência, confiança e por me orientar dentro de um tema tão complexo, atual e inacabado quanto o é a habitação.

Agradeço especialmente a Alexandre Pereira Cruce, pelo companheirismo, pelos longos diálogos, incluídos ao longo de todo o trabalho e pela cuidadosa revisão. 
Embora em aparência São Paulo seja como quase todas as metrópoles mundiais de hoje fragmentada, segregada, contraditória e rica, sua conformação se deve a fatores muito particulares. O rápido crescimento (tanto econômico como demográfico) sobre um território específico levou-a hoje a uma conformação que deve ser compreendida para que futuras intervenções possam ser eficazes e proporcionar melhor qualidade de vida a seus moradores.

A leitura empreendida na presente dissertação se faz a partir da análise das questões habitacionais na cidade, considerando as diversas formas de produção e oferta habitacional, seja pelo Estado ou pela iniciativa privada, e seus reflexos nas principais características arquitetônicas e urbanísticas.

A pesquisa iniciou-se como reflexão da prática profissional em projeto de arquitetura e urbanismo na área de projetos na CDHU (Companhia de Desenvolvimento Habitacional e Urbano do Estado de São Paulo).

O objetivo da pesquisa num primeiro momento era ter conhecimento histórico da evolução das questões habitacionais de massas na cidade de São Paulo a partir de seu ingresso na era industrial.

No primeiro capítulo é elaborado um histórico da forma de morar do paulistano, desde as primeiras povoações até a chegada ao século XX. As posturas das administrações municipais frente aos rumos dados ao crescimento urbano pelas atividades agroexportadoras cafeeiras são analisados tendo como foco as questões habitacionais. As influências externas e a intervenção da iniciativa 
privada na produção de moradias urbanas, somadas à omissão do Estado, geraram vetores que influenciaram o desenho urbano, base para uma modernização posterior.

No segundo capítulo se analisa o desenvolvimento e a modernização da malha urbana produzida nos séculos anteriores, para o novo papel que a cidade vem a assumir no cenário econômico nacional, vista sempre a partir da ótica da habitação das massas citadinas, mostrando a consolidação de uma estrutura que se reproduziu de forma espraiada por todo o município de São Paulo, servindo de modelo aos municípios vizinhos na região metropolitana e constituindo-se em padrão para as demais regiões metropolitanas do estado de São Paulo.

Devido a especificidade dos projetos desenvolvidos na CDHU na área de urbanização de favelas, a partir do terceiro capítulo os objetivos foram entender os fenômenos:

1) de favelização;

2) de intervenções públicas nas favelas, quais seja erradicação total ou urbanização;

3) uma vez feita a opção pela urbanização, dos processos de projeto de urbanização de favelas que têm norteado essas intervenções no Brasil.

No terceiro capítulo, inicia-se um levantamento de algumas metodologias de projeto de urbanização assentamentos invadidos (entre eles as favelas) através da leitura de experiências analisadas por diversos pesquisadores nas últimas 5 décadas no Brasil e em experiências em outras cidades em países periféricos. Procura-se identificar o atual estágio do desenvolvimento do processo 
de projeto de urbanização de favelas, e elencar os principais elementos de projeto que podem - ou poderiam - ser utilizados como parâmetros para futuros projetos.

No quarto capítulo toma-se uma favela metropolitana paulista (visto que as dinâmicas urbanas são semelhantes nas regiões metropolitanas paulistas) - a Favela México 70 - como ponto de partida para reflexões dessas práticas de projeto, procurando colaborar no desenvolvimento dos atuais estágios de desenvolvimento dos processos de projeto de urbanização de favelas, inaugurando indagações para reflexões futuras. 
Though it resembles many of metropolitan cities in the world today - fractured, segregated, contradictory, and rich - São Paulo inherits its configuration from a number of unique factors. Its rapid growth, both economic and demographic, on a specific territory has led to such a configuration that it must be properly understood so that future interventions, intended to improve the city's efficiency and to provide better quality of life to its inhabitants are to achieve success.

The perusal applied to the present study is founded on the analysis of habitation issues in the city, taking into account the diversity in forms of housing production and supply, either Statesponsored or driven by private ventures and their reflection on the principal local architectural and urban features.

This research was initiated due to the professional practice and development of projects at the Department of Projects at CDHU (Company for the Development of Habitation and Urbanism of São Paulo).

At first the aim of this research was to gain historical knowledge of the evolution of those issues in the mesh of the city of São Paulo since its entrance into the industrial era.

The first chapter traces the history of the manner of living of the paulistano ${ }^{1}$ from the earliest settlements to the dawn of the 20th century. The position of successive municipal administrations in the face of the course of urban growth due to the activities in coffee exports is analyzed with a focus on habitation issues. External influences and the intervention of private ventures in the production 
of urban housing, plus the omission of the State, generated vectors that influenced the urban layout, serving as a basis for later modernization.

The second chapter analyzes the development and modernization that took place on the existing grid produced over the previous centuries and configured a new urban structure for the new role the city came to play in the Brazilian economic stage, always pondered through the eyes of housing solutions to the urban masses, revealing then the consolidation of a structure that reproduced itself in the swollen, outstretched pattern that typifies São Paulo - to the point of serving as a model not only to neighboring cities within the metropolitan region, but also to other metropolitan regions in the state of São Paulo.

Due to the specificity of the projects developed at CDHU in the favela urbanization field, from the third chapter the purpose was to understand the phenomena:

1) the outbreak and development of the favelas;

2) the public interventions there, being either total erradication total ou urbanization;

3) the process of urbanization projects that have been guiding those interventions in Brazil, once the option for the urbanization was taken.

Through the analysis of these experiences from a diversity of researches from the last five decades in Brasil and also experiences from surrounding cities and countries, the third chapter 
brings a survey on some project methodologies for urbanization of invaded ground plots (the favelas amongst them). The aim is to identify the present development of the urbanization project process of the favelas, and address the main elements of this project that can - or could - be used as parameters to future projects.

The fourth chapter presents The 'Favela México 70' - one of the favelas ${ }^{2}$ of the metropolitan region - taken as the starting point to some considerations of the projects development, with the aim to collaborate to the further evolution of the stages of fruition of the processes that go into the projects of the urban intervention at the favelas, opening question to future considerations.

2 The particular development, in Latin American areas - and especially in Brazil - of usually extensive areas of land encroachment and dwellings built without compliance to building regulations. Many translate this term to slums but the terms is not accurate enough to the phenomenon described in this work. 
RESUMO

SUMÁRIO

CAPÍtUlo I - A EVOLUÇÃo dA HABITAÇÃo NA CIDADE DE SÃo PAULO. A forma de morar do paulistano na chegada ao século $X X$

1.1 INTRODUÇÃO

1.2 SÃO PAULO E A HABITAÇÃO

1.2.1 A casa no centro urbano de são Paulo

1.3 AS MUDANÇAS NAS CASAS URBANAS

1.3.1 A casa paulistana na economia do café - o que o trem traz

1.4 CONCLUSÃO 


\section{CAPÍTULO II - A MODERNIZAÇÃo NA CIDADE DE SÃO PAULO}

2.1 INTRODUÇÃO

2.2 A CONSTRUÇÃO DOS ESPAÇOS INTRA-URBANOS

2.3 A ARQUITETURA BRASILEIRA NAS NOVAS CIDADES

2.4 A VIDA URBANA CONSOLIDADA

2.5 HABITAÇÃO COLETIVA EM SÃO PAULO E A VERTICALIZAÇÃO

2.6 CONCLUSÃO 


\section{CAPÍtUlO III - RECUPERAÇÃo DE ÁREAS DEGRADADAS DESTINADAS AO USO} HABITACIONAL

3.1 INTRODUÇÃO

3.2 A FAVELA COMO REALIDADE URBANA

3.3 O PROCESSO DE URBANIZAÇÃO DE FAVELAS: UM VASTO PANORAMA

3.4 A RECUPERAÇÃO URBANA COMO POLÍTICA PÚBLICA

3.5 URBANIZAÇÃO DE FAVELA E RECUPERAÇÃO URBANA: REFLEXÕES SOBRE O PROCESSO DE PROJETO

3.6 ALGUMAS EXPERIÊNCIAS DE PROJETOS DE URBANIZAÇÃO DE FAVELA

3.7 CONCLUSÃO 


\section{CAPÍTULO IV - URBANIZAÇÃO DE FAVELAS: POLÍtICAS PÚBLICAS E SEUS PROJETOS}

4.1 INTRODUÇÃO

4.2 A FORMAÇÃO DAS POLÍTICAS PÚBLICAS PARA A URBANIZAÇÃO DE FAVELAS

4.3 OS PROJETOS DE URBANIZAÇÃO DE FAVELAS

4.3.1 Os programas habitacionais da CDHU e a urbanização de favelas

4.4 O PROJETO DE URBANIZAÇÃO NA FAVELA MÉXICO 70

4.5 CONSTRUIR CIDADE NA PERIFERIA

4.6 CONCLUSÃO

CONCLUSÕES FINAIS

Bibliografia 
Capítulo I

A evolução da habitação na cidade de São Paulo A forma de morar do Paulistano e a chegado ao século $X X$ 
O tema da atual pesquisa - 0 espaço doméstico na cidade de São Paulo: um projeto arquitetônico - tem caráter eminentemente contemporâneo, ao tentar traçar o quadro da habitação na cidade nesta primeira década do século XXI.

Como analisa Ferreira (2007), por ser São Paulo hoje uma grande cidade, destacando-se sob vários aspectos no cenário global, aglutinando cerca de 10 milhões de pessoas e sendo uma das maiores geradoras de renda no país, tende-se a defini-la como uma cidade global. Com isso, o desejo de ser um entro de modernização a leva a comparar-se com cidades globais, que se inserem no mundo diferentemente de São Paulo e cujas dinâmicas internas diferem daquelas desta cidade, correndo-se o risco de menosprezar as particularidades internas e suas dinâmicas, que são o que realmente define os espaços intra-urbanos.

Não sendo a cidade global o tema da pesquisa, nem tampouco o homem contemporâneo dos grandes centros urbanos globais, cabe aqui destacar os vetores de expansão e readequação internos que operam em uma realidade de profundos contrastes sociais e espaciais, que evidenciam uma questão de grande atualidade, que é a habitação dos paulistanos. 
Esses contrastes fazem com que realidades diversas convivam num mesmo espaço geográfico e criem um paulistano que, embora cidadão urbano, mora de formas diferentes.

O fato de não haver uma forma única de morar do paulistano torna complexo o desenvolvimento de projetos urbanos, uma vez que são muitas as formas de morar e muitos são os paulistanos, herdeiros de uma história urbana povoada de privilégios para uns e de carência para outros - uma cidade que se construiu à custa de interesses de poucas camadas da população, tendo sido o planejamento e o desenho urbano muitas vezes usados apenas para ratificar situações já configuradas e assegurar os privilégios urbanos que alguns já possuíam, de acordo com Vilariño (2006).

Nesse cenário, para quem se disponha a trabalhar também com a porção do espaço da cidade deficitária de serviços urbanos os mais diversos, torna-se difícil estabelecer parâmetros urbanísticos e arquitetônicos voltados a manter um bom nível de qualidade urbana em prol de uma cidade que vise o bem comum, em que tanto a arquitetura quanto o urbanismo possam contribuir. Frente aos contrastes marcantes e à pronunciada segregação social, pode parecer quase quixotesco ingressar em tão árido território.

Assim, procurou-se traçar um percurso histórico da evolução da habitação em São Paulo, tentando-se, com esse conhecimento, evitar a mera importação de modelos distantes dos contextos espaciais das cidades brasileiras. Essa rica história, fonte de grande material programático e projetual, não pode passar despercebida. 
Para tanto, inicia-se mostrando o caminho da evolução das habitações no Brasil, de forma mais ampla, passando por correntes de pensamento urbanístico e arquitetônico que influenciaram a dinâmica urbana interna até as primeiras décadas do século $X X$, são tecidos breves comentários sobre a legislação urbanística que diretamente influenciava os projetos de áreas residenciais.

Analisa-se o início da urbanização na cidade até a entrada no século $X X$, momento em que esta passou por grandes transformações físicas sob um legado construído deixado pelo período anterior.

No período colonial, a vida urbana em São Paulo em nada se assemelhava à das principais cidades que lhe eram contemporâneas - Belém, Olinda, Recife, Salvador, Alcântara - , em que as construções destinadas à habitação (os sobrados urbanos) apresentavam uma sofisticação não encontrada no núcleo urbano paulistano durante os primeiros 300 anos, até a fase da exportação do café.

A cidade não tinha grande expressão na vida econômica da colônia, e sua importância resumia-se à estratégia de conquistas no interior do território, empreendidas por meio de bandeiras. As escarpas da Serra do Mar dificultavam o acesso de colonizadores, isolando o núcleo urbano dos processos que se davam nas cidades litorâneas, fortemente ligadas às metrópoles européias.

O isolamento da São Paulo do século XVII tornava possível o desenvolvimento de uma arquitetura local, expressa na casa bandeirista, sem influências constantes do modo de vida urbano 
europeu. Segundo vários estudiosos, a casa bandeirista seria uma das mais autênticas expressões da arquitetura autóctone, de caráter fortemente rural, conforme Lemos (1979).

O centro urbano constituía-se em apoio às atividades tropeiras que se cruzavam em São Paulo, importante ponto na ligação entre o interior e o litoral, com algum comércio e serviços de alojamento. As moradias urbanas serviam de hospedagem aos proprietários rurais em ocasiões especiais que tinham lugar no centro urbano, estagnado na maior parte do ano. As demais moradias localizavam-se sempre muito próximas às residências senhoriais, erigidas com o mesmo processo construtivo (taipa de pilão), com os mesmos materiais, diferindo apenas em sua composição interna e externa, dimensionamento e relação com a rua, mas sem alcançar grande importância na vida citadina.

A partir da economia do café, São Paulo vivenciou várias transformações, e o centro urbano passou a exigir uma estrutura maior e mais bem equipada. As atividades da cidade tornavam-se mais complexas, ligadas à economia do café e a todo o aparato necessário ao desenvolvimento das atividades agroexportadoras, da fonte produtora ao porto exportador e importador de bens de consumo.

Mais tarde, a industrialização veio acentuar as características marcadamente urbanas, introduzindo um novo elemento humano - os operários industriais e toda sua dinâmica na vida urbana. 
São Paulo passava assim a se especializar em setores econômicos industriais, comerciais e de serviços, o que a levava a setorizar também as áreas residenciais em função das atividades da população ligada a elas:

"A estruturação das cidades - conforme revelou o famoso estudo da aglomeração paulistana feito pela equipe do padre Lebret - seguia a lógica da segregação social, a qual se baseava, por sua vez, na localização residencial em função dos empregos e dos serviços urbanos. Assim, as classes altas e médias altas moravam perto do centro onde estavam seus empregos e seus serviços, os operários ficaram próximos das fábricas e os excluídos ficavam longe de tudo." (QUINTO JR., 2003, apud VILARIÑO, 2006) [grifo nosso] 


\subsection{Săo Paulo e a habitação}

Todas essas mudanças contribuíram para criar uma demanda habitacional que ia se

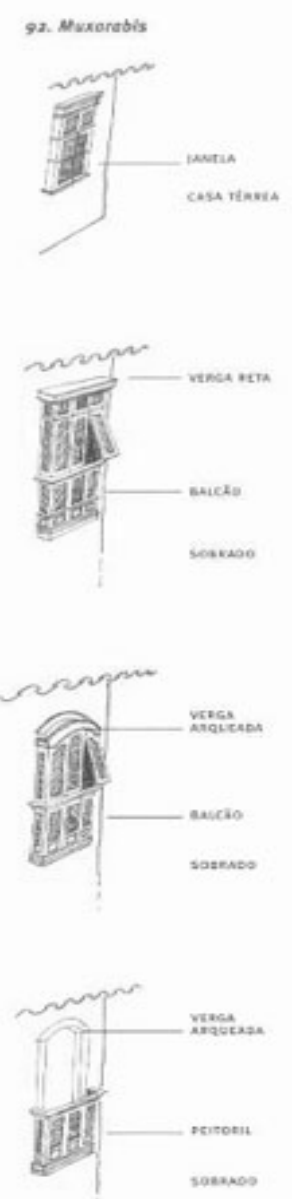
ajustando à medida do possível e da necessidade, sem que em momento algum houvesse qualquer tipo de planejamento urbano com diretrizes nítidas ligadas às questões de moradia na crescente escala da cidade em expansão que foi São Paulo nessa fase.

O sobrado foi uma das mais sofisticadas formas da morada urbana do Brasil Colônia, que se repetiu em várias cidades por todo o país, por longos períodos. Uma forma mais simples era a casa térrea, que diferia do sobrado, sobretudo na quantidade de itens do programa, na maior sobreposição das funções domésticas e no revestimento do piso: no sobrado, o assoalho; na térrea, a terra batida, com claras diferenças sociais agregadas, conforme Lemos (1979).

\subsubsection{A casa no centro urbano de São Paulo}

O sobrado urbano brasileiro permanecera o mesmo em sua conformação espacial até o fim da era colonial, com a entrada do ciclo do café e a proclamação da república, que trazia consigo a nova visão positivista, em desenvolvimento nos grandes centros europeus.

Os melhores expoentes dessa tipologia não se encontravam em São Paulo, mas sim nas cidades importantes do período, no Nordeste Brasileiro (Recife, Salvador) e no Rio de Janeiro, cidades litorâneas. 


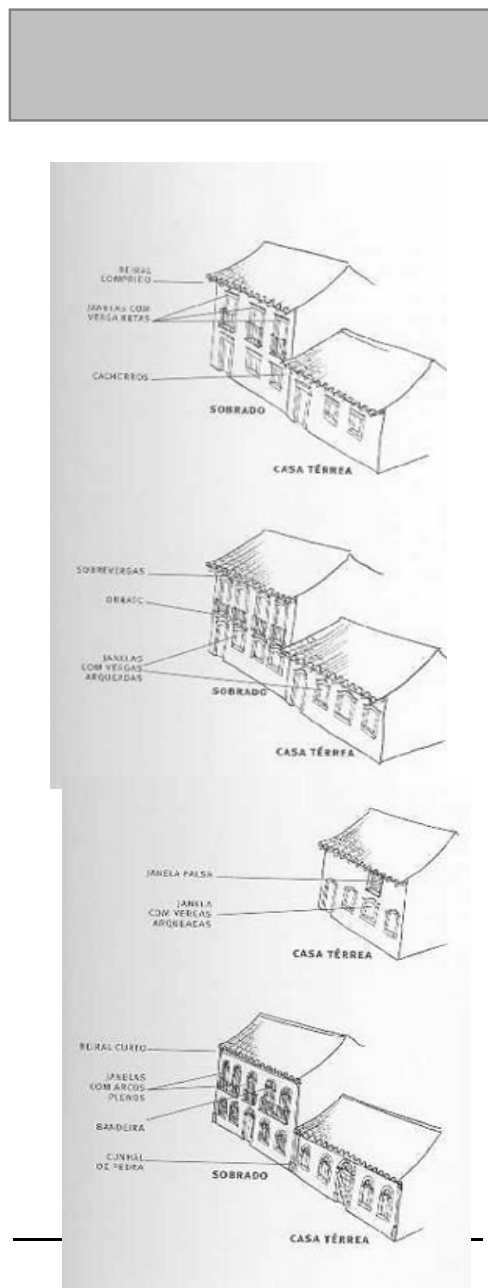

Fig. 1 - Esquema das moradias no centro urbano de São Paulo (Reis, 2004)
Numa estrutura social e vida urbana muito mais simples, as moradias em São Paulo não apresentavam nenhuma sofisticação construtiva nem de agenciamento interno. Geralmente eram casas térreas, em sua maioria ao rés do chão, com piso de terra batida. O espaço interno (privado) e o espaço externo (público) eram separados pela fachada frontal, tendo a porta e a janela a função de contato exterior-interior. As funções domésticas eram desenvolvidas por serviçais negros, elo entre o mundo interno e externo, além de atuarem como a máquina da casa - realizando desde o abastecimento de água até o transporte do esgoto, de acordo com Lemos (1979).

Interna à vida doméstica, a cozinha permanecia em zona-limite entre o interior e o exterior, e junto a ela se localizava um telheiro isolado, que servia a serviços de limpeza e onde mais tarde se instalaria o tanque. A lavagem de roupas era feita às margens dos rios ou em tanques públicos. Também de rios e chafarizes públicos era feito o abastecimento da água utilizada na moradia. Os quartos localizavam-se no meio da edificação - as alcovas - e não dispunham de iluminação direta. A sala de estar situava-se junto à entrada da moradia e o convívio íntimo familiar se dava na varanda alpendrada aos fundos, onde se comia, se conversava e se faziam pequenos serviços.

O período da cana-de-açúcar no interior do estado, atividade econômica de destaque, ${ }^{3}$ levou novamente a mudanças nas características das moradias e, conseqüentemente, das cidades.

3 "As características econômicas paulistas começaram a se modificar a partir do "renascimento agrícola", que se iniciou na segunda metade do século XVIII, com uma agricultura voltada para o mercado externo. O comércio interno continuou a ser importante para a economia de São Paulo até o início do século seguinte; mas a lavoura da cana foi crescendo e ganhando espaço na geração de riqueza.

O açúcar só surgiu como um produto de exportação importante para a Capitania quando o interior paulista começou a produzir quantidade suficiente para atingir o comércio externo. A partir de 1765, a atividade passou a ser um empreendimento voltado ao mercado mundial, permanecendo como fonte principal da economia paulista por mais três quartos de século. 
A casa paulista sofreu, com o declínio da extração de minérios na região das Minas Gerais, grandes influências trazidas de cidades com centros urbanos mais desenvolvidos, como Ouro Preto, Mariana e Tiradentes, quando da volta dos paulistas que para lá haviam se dirigido.

Se a casa bandeirista se implantava sobre plataformas planas, as casas dos mineiros se erguiam do chão, respeitando a topografia. Assim, o porão - que não existia na casa bandeirista passa a ser usado como depósito, com o nível térreo, o maior da casa, abrigando atividades de estar, serviço e repouso noturno. A dispersão das construções de apoio às atividades produtivas tão comum no agenciamento da casa bandeirista - deu lugar à aglutinação das atividades domésticas e produtivas, se possível num espaço só.

O alpendre frontal da casa bandeirista passou, dentro do novo agenciamento, a localizar-se nos fundos da casa, voltado à área externa. Dessa forma, seu uso passou de "público e social" a "privado e doméstico". Ao localizar-se próximo à cozinha, ganhou a denominação de varanda, aglutinando as mais diversas atividades domésticas, e introduzindo um tratamento da fachada posterior aberta ao exterior, com aberturas maiores que na fachada frontal, modificando a relação entre o interior e o exterior da moradia, no âmbito da vida privada.

No ciclo seguinte, o do café, a varanda foi se adaptando. A aproximação dos serviços à zona de estar social da família se justifica, segundo Lemos (1978) pela condição feminina nos afazeres domésticos. Ao mesmo tempo em que podia ser a baronesa, a mulher era também a

Para o escoamento da crescente produção açucareira do interior era fundamental a existência de caminhos entre o planalto e o litoral. Após a restauração da Capitania, a conservação das estradas passou a ter um significado maior, isto é, de atendimento aos interesses expansionistas de Portugal em relação ao sul do continente." (MENDES, D. IN http://www.historianet.com.br/conteudo/default.aspx?codigo=606). Acesso em 09/02/2009 
administradora do agenciamento dos afazeres domésticos. O esquema geral não havia se alterado, não se contando ainda com nenhuma infra-estrutura urbana de abastecimento de água e esgotamento sanitário.

À medida que a cidade crescia, a concentração populacional criava problemas urbanos que demandavam decisões mais elaboradas. Não apenas a concentração populacional exigia novas soluções, mas também as atividades e serviços urbanos, até então inexistentes, requeriam um novo espaço urbano, com novas relações urbanas e um novo urbanismo.

Na cidade de São Paulo, a partir do final do século XVIII, algumas melhorias urbanas começavam a surgir - arruamentos, iluminação, calçamentos, chafarizes, oferecendo mais comodidade aos moradores - , mas as casas e sobrados, a forma de morar e de construir, a vida cotidiana, essas não se alteraram significativamente.

Até 1820 as casas eram feitas de taipa de pilão, com corredores centrais ou laterais, alinhadas e geminadas, com a água de telhado voltada para a rua e habitadas por famílias modestas, com exceção daquelas feitas para o senhorio, que eram geralmente assobradadas, com comércio embaixo e residência em cima.

Uma das primeiras casas urbanas na cidade talvez tenha sido a da Marquesa de Santos. O sobrado urbano pontuava a paisagem com uma sofisticação que a cidade ainda desconhecia. 
1.3. As mudanças nas casas urbanas

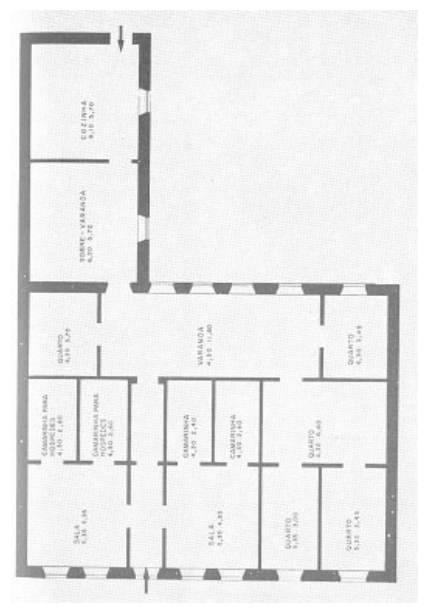

Fig. 2 - Casa urbana campineira, em taipa de pilão. $2 .^{\circ}$ quartel do século XIX (Lemos, 1978)

\subsubsection{A casa paulistana na economia do café - 0 que traz o trem}

Até a implantação da estrada de ferro, qualquer alteração que tenha havido nas moradias não alterava o uso da principal força motriz: o escravo. Nas palavras de Lúcio Costa:

"A máquina brasileira de morar, ao tempo da colônia e do império [...] [dependia] dessa mistura de coisa, de bicho e de gente, que era o escravo [...]. Era ele que fazia a casa funcionar: havia negro para tudo - desde negrinhos sempre à mão para recados, até negra velha, babá. O negro era esgoto, era água corrente no quarto, quente e fria; era interruptor de luz e botão de campainha; o negro tapava goteira e subia vidraça pesada; era lavador automático, abanava que nem ventilador." (COSTA, apud LEMOS, 1978)

O desenvolvimento propiciado pela economia do café trazia a São Paulo hábitos inéditos, e a estrada de ferro marcava seu ingresso na era dos progressos sociais e materiais. Em 1867 era inaugurada a estrada de ferro Santos-Jundiaí. Em 1872, a via férrea chegava até Campinas e em 1875 ligava São Paulo ao Rio de Janeiro.

Em 1888, a abolição da escravatura trazia a exigência de grandes modificações nas casas, uma vez que não haveria mais força humana para fazê-la funcionar nas mesmas condições. Esse progresso encontrava uma cidade organizada, segundo Reis Filho:

"[...] em um tipo de lote com características bastante definidas. [...] nossas vilas e cidades apresentavam ruas de aspecto uniforme, com residências construídas sobre o alinhamento das vias públicas e paredes laterais sobre os limites dos terrenos. Não havia meio termo; as casas eram urbanas ou rurais, não se concebendo casas urbanas recuadas e com jardins." (REIS FILHO, 2004, p. 23) 


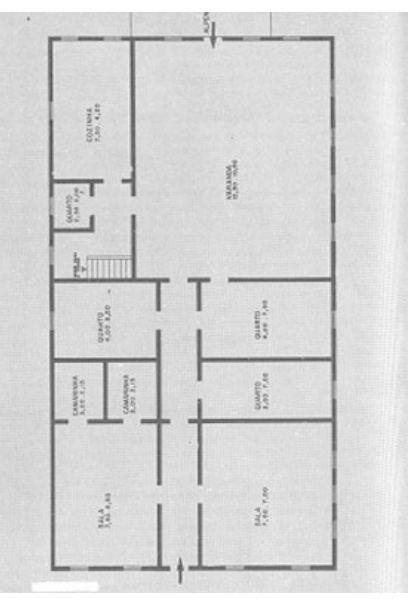

Fig. 3 - Casa urbana campineira construída em taipa de pilão (Lemos, 1978)
O grande acúmulo de riquezas propiciado pela economia do café e a nova dinâmica urbana de São Paulo tinham o efeito de estimular na elite cafeeira a aquisição de hábitos predominantemente europeus, de preferência dos centros urbanos mais desenvolvidos, como Paris e Viena. Os hábitos sociais e domésticos se alteravam, num contraste entre os barões analfabetos e seus descendentes que introduziam hábitos europeus, o francês como língua para uso em família, governantas estrangeiras, dentre outros hábitos.

Os hábitos europeus chegavam também com a imigração, atingindo outra camada social. Trabalhadores, gente comum, pequenos prestadores de serviço especializados iam fazendo parte desse contingente. Novas técnicas construtivas eram introduzidas, com decorrente surgimento de pequenos estabelecimentos produtivos, oficinas mecânicas, fundições, olarias, fabricação de tubos para encanamentos e saneamento etc.

O automóvel passava a circular pelas ruas da cidade, o que contribuía para a expansão urbana, favorecendo o espraiamento da cidade. As primeiras fases da expansão urbana foram marcadas pela abertura de loteamentos no rumo oeste do centro histórico, inaugurando uma dinâmica de crescimento urbano radiocêntrico, induzido pela abertura de loteamentos residenciais.

Por outro lado, pequenos construtores europeus, a leste do centro, próximo às áreas industriais, contribuíam para a construção de moradias populares, enquanto a elite cafeeira trazia arquitetos estrangeiros para projetarem suas casas em bairros modernos que se implantavam a oeste do centro original. A mão-de-obra da construção passava a se especializar, trazendo novas 
técnicas. No entanto, a taipa de pilão ainda era uma técnica amplamente utilizada nos casarios da época.

Essas novidades, no entanto, não eram capazes de alterar estruturalmente as moradias:

" [...] [n]aquelas casas do café esquemas de circulação em que está implícita a varanda como o centro de interesse do lar. A varanda comprida, atravessada na casa. Da rua, ou do jardim da fazenda, pela única porta central, vai-se, por corredor largo, à varanda. Na frente, dos dois lados desse corredor, as salas. No meio, as alcovas. E, da varanda, nos fundos, chega-se à cozinha e dependências. [...] Nos sobrados, quase sempre com comércio embaixo, a escada substitui o corredor: em cima, o patamar distribui os passos: salas na frente e a varanda atrás. [...] As cozinhas, com despensas anexas, quartinhos para guardados, tinham portas para os quintais, onde se lavava a roupa [...]. E nos quintais ficava a casinha - nas cidades sempre construída sobre uma fossa negra. A criadagem dormia aqui e ali [...]. As casas elevadas, em princípio, prescindiam das dependências clássicas nos quintais." (LEMOS, 1972, p. 119-120)

O que passou a haver foi uma maior sobreposição das funções domésticas ${ }^{4}$.

Somente a partir da década de 1880 foi que se veriam em São Paulo edificações de importância, em novos bairros construídos com melhoramentos públicos. A ocorrência mais importante, porém, provavelmente foi a chegada da ferrovia, de 1867 a 1875.

Segundo VILARIÑO (2006):

4 Para Lemos (1972), a sobreposição de funções domésticas no agenciamento da moradia expressa o nível que a família ocupa na escala social. O que distingue uma residência rica de uma modesta é o grau em que as funções domésticas se sobrepõem no uso dos espaços físicos da moradia. 
"Até 1930 o setor dinâmico da economia foi a atividade do complexo agroexportador, portanto a demanda não era a cidade entendida como o lócus da produção, mas o transporte e a circulação de mercadorias para atender às necessidades da atividade agrícola. As administrações públicas priorizavam as infraestruturas de circulação, o saneamento e a reforma das cidades portuárias, evitando a interrupção do funcionamento dos portos brasileiros [...].

A chegada da ferrovia [...], que confere à cidade um importante papel de ligação entre as áreas agrícolas do interior e o Porto de Santos, dando início ao processo de acelerada expansão urbana. [...] por outro lado, uma epidemia de febre amarela que acomete [...] Santos e Campinas [....] inviabiliza essas cidades como centro de moradia das classes dominantes. Livre de epidemias, São Paulo passa a sediar as moradias urbanas dos principais fazendeiros de café e toda a estrutura administrativa e econômica ligada ao comércio de importação e exportação."

Essa dinâmica de crescimento da cidade atraía o interesse de investidores estrangeiros e "portanto, eram três os principais agentes que atuavam na configuração da cidade de São Paulo: a municipalidade, no atendimento dos interesses da economia cafeeira e da classe oligárquica; as empresas de infra-estrutura urbana e as empresas imobiliárias privadas" (VILARIÑO, 2006, p. 17).

A questão habitacional, entretanto, em termos de atendimento habitacional digno, não era vista pela municipalidade como prioritária.

A abertura de loteamentos sem continuidade com o núcleo urbano passava ser a característica principal que orientava a expansão urbana da cidade.

A sociedade, no entanto, ia se sofisticando. Os moradores notáveis da cidade mantinham estreito contato com suas regiões produtoras, as fazendas de café, através da ferrovia, e aos 
poucos se inseriam na vida urbana em novas profissões, com instrução de nível superior, ocupando postos de diretores de estradas de ferro, pioneiros da indústria, banqueiros.

As classes médias se constituíam principalmente de imigrantes: "As oportunidades criadas pelas tendências de desenvolvimento urbano da economia paulista vão beneficiar os imigrantes europeus e muito pouco os mulatos e negros libertos" (BASTIDE; FERNANDES, apud LEMOS, 1978, p. ...). Os mulatos e negros sem qualificação eram os mais prejudicados.

As empresas imobiliárias colocavam no mercado diversas opções para as parcelas mais abastadas: Vila Buarque (1890), Avenida Paulista (1891), Higienópolis (1898), Mirandópolis (1919), Vila das Jabuticabeiras, (1925), Vila Monumento, Ipiranga (1925), Jardim Japão, Alto da Bela Vista (1925), Vila Conceição (1926) e, entre outros empreendimentos de 1928 da Cia. City, Jardim América, Pacaembu, Alto da Lapa e Perdizes.

Em 1879 era feito o primeiro loteamento em chácara no bairro dos Campos Elíseos. Ingleses construíam o sistema de captação e distribuição de água da Cantareira. Dez anos depois, cinco mil edifícios eram servidos por água. Nessas últimas décadas do século XIX, São Paulo se equipava com bondes e iluminação pública, as casas passavam a ter equipamentos sanitários, luz elétrica e outros novos recursos. À medida que se sofisticavam as moradias centrais, as mesmas demandas se estendiam para as moradias periféricas. A instalação de infraestrutura e equipamentos nas zonas centrais e a demanda das moradias periféricas alimentavam uma necessidade crescente de expansão das redes então instaladas. 
Na última década do século XIX, arquitetos alemães construíam várias casas e vilas para as principais famílias da cidade. Nos últimos anos da década, mestres, arquitetos e engenheiros italianos eram os responsáveis pela maioria das obras.

A cidade operária e popular se construía em outra direção. Lemos (1978), em pesquisa no Arquivo Histórico Washington Luís, da Prefeitura de São Paulo, encontrou projetos dos "representantes verdadeiros do povo, desde os imigrantes humildes até aos elementos da classe média" datados de 1870 até o início do século XX, de onde se puderam obter informações valiosas sobre essas moradias.

Por volta de 1916, na gestão de Washington Luís na Prefeitura de São Paulo, já havia se estabelecido na cidade uma grave crise habitacional, havendo para a classe operária duas alternativas: ou as casas arrendadas, que subiam de preço sistematicamente, ou os cortiços. Nesse ano, a municipalidade, na administração de Washington Luís, abria concorrência pública para apresentação de projetos de casas operárias, a fim de alimentar um estoque de projetos. Ainda no começo do século XX, segundo Segawa (2004, p. 160-161):

"O termo 'casas operárias' participava do corpo de definições do código de obras da cidade de São Paulo até os anos 1960, enquanto vigoravam as atualizações do Código de Obras Arthur Saboya, de 1929. Nele, definia-se 'casa operária' como a edificação 'que contiver, no máximo, três peças, entre aposentos e salas, além da cozinha e privada'. Enquadrava-se na categoria de habitações populares, caracterizada como 'toda aquela que dispõe, no mínimo, de um aposento, de uma cozinha e de compartimento para latrina e banheiro e, no máximo, de duas salas, três aposentos, cozinha, copa, despensa e de compartimento para latrina e banheiro, sem contar a garagem e o quarto de criada', 


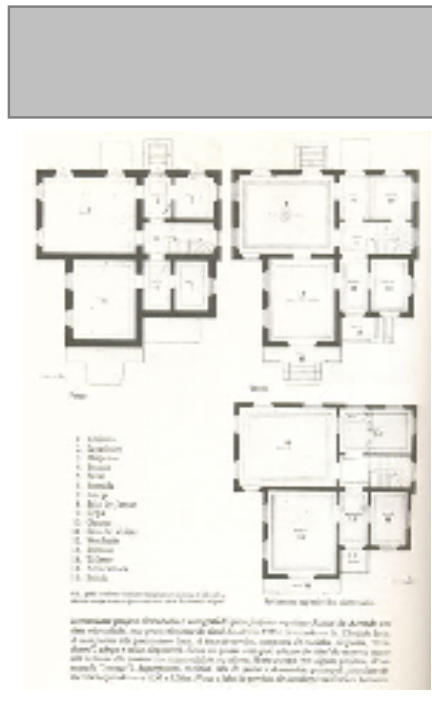

Fig. 4 - As novas plantas sugeriam novos agenciamentos da moradia (Lemos, 1985)

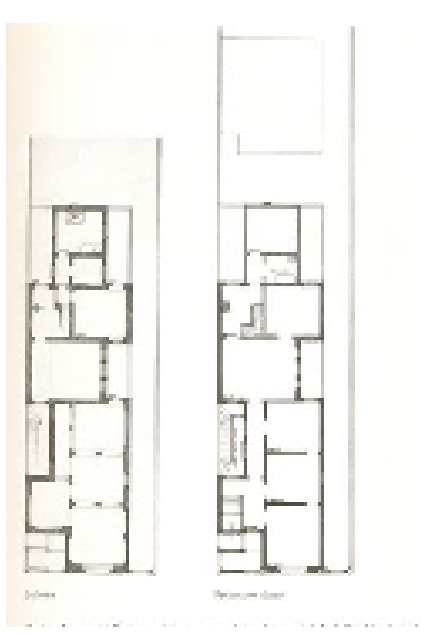

Fig. 5 - Iluminação de todos os cômodos, alcançada com uso de corredor externo lateral (Lemos, 1985) em oposição à 'habitação residencial', definida como 'toda aquela que, dispondo de qualquer número de peças, as dimensões excedam aos limites máximos impostos para os das habitações 'populares'. A caracterização de um tipo 'operário' para habitação devia-se, na óptica do código, à dispensa de 'alvará de construção' na zona rural, obrigatório a quaisquer construções novas na zona urbana de São Paulo, além da isenção de taxas municipais'."

E continua Segawa (2004, p. 160-161):

"Esta configuração do Código Saboya é reminiscência da lei 498 de 1900, que 'estabelece prescrições para construção de casas de habitação operária'. Nessa norma, determinava-se o mínimo de três compartimentos, incluindo-se a cozinha, e rezava expressamente que tais construções eram somente admitidas fora do perímetro marcado na lei. Uma periferização compulsória [grifo nosso] cuja segregação espacial já se fazia presente no Código Sanitário do Estado de São Paulo de 1894 ('as vilas operárias deverão ser estabelecidas fora da aglomeração urbana'), e bem antes, no Padrão Municipal de 11 de agosto de 1886, dedicava-se em um mesmo capítulo prescrições comuns a 'cortiços, casas de operários e cubículos', todos 'proibidos no perímetro do Comércio'."

Aos mulatos e negros quase nada restou, porque não tinham como se inserir na economia em expansão. No entanto continuavam a alimentar as massas trabalhadoras, sem qualificação, mas que demandavam habitação.

A vida urbana consolidava-se cada vez mais em atividades ligadas ao comércio, indústria, serviços, educação e lazer e delas se beneficiavam, ainda que em graus diferentes, os "incluídos" e os "excluídos". A vida urbana continuava a ser atraente, pois lançava uma esperança de qualidade e progresso. 


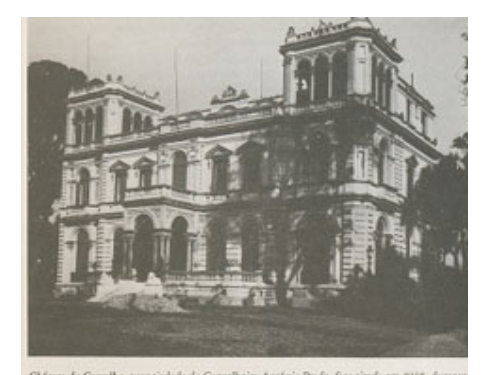

Fig. 6 - Chácara do

Carvalho, morada burguesa (Lemos, 1985)

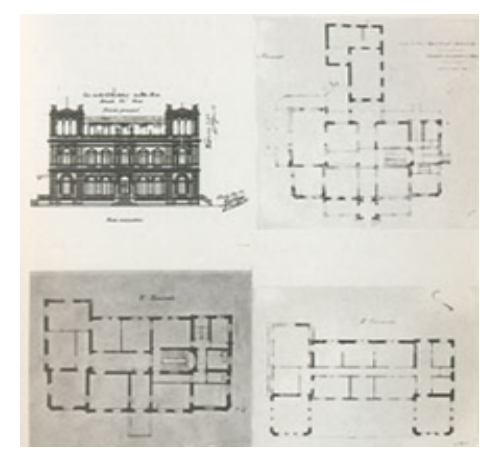

Fig. 7 - Chácara do Carvalho, morada burguesa (Lemos, 1985)
A composição tão heterogênea da população, as demandas que cada uma das camadas sociais criava, a relação de dependência entre elas e a exclusão espacial tão marcante na paisagem urbana paulistana eram características que, a cada momento, tornavam a questão habitacional mais complexa e difícil de ser enfrentada pelo poder público. Qualquer intervenção, ainda no começo do século XX, já demandava grandes investimentos e os projetos de concurso se apresentavam muito dispendiosos para o nível de renda dos operários e populares. Em nenhum momento, porém, cogitou-se em subsidiar essas moradias para a compra ou utilizar locações sociais (imóvel habitacional de propriedade do poder público com aluguéis simbólicos e prazos longos de contrato de locação para a população de menor poder aquisitivo).

Os bairros se expandiam, estendendo a periferia de maneira descontínua, com características físicas diversas e desconectadas. Bairros operários a leste e sul, bairros modernos a oeste, bairros populares a sul e norte, e o centro se sofisticando e se urbanizando com infraestruturas, serviços, comércios, equipamentos de lazer e cultura, criando um forte pólo de atração. Tal cenário era bastante propício à especulação imobiliária, que, nos vazios urbanos criados entre um loteamento e outro, se beneficiavam com a instalação da infra-estrutura pelo poder público e, conseqüentemente, com a valorização do solo urbano.

Até 1925-30, nas casas de classe média era freqüente o uso da varanda, que constituía o centro das atenções, o estar da família. A disposição dos demais cômodos era confusa, com a introdução de uma passagem externa lateral, ao invés do corredor central das antigas casas. A evolução das técnicas construtivas, com a utilização de calhas e dutos, possibilitou a construção de 
telhados elaborados, de quatro águas ou mais, facilitando o afastamento da casa às divisas laterais do lote, já que por lei, naquela ocasião, era necessário que todos os cômodos tivessem janelas para o exterior. Essa mudança causava certa confusão espacial e a circulação interna por vezes se dava através dos cômodos.

Os contrastes entre as áreas urbanizadas e aquelas por urbanizar começavam a tornar-se pronunciados. As habitações populares, construídas por pequenos construtores para aluguel, passavam a se tornar homogêneas, enquanto o ecletismo e a busca constante por novidade e diferença imperavam nas casas das famílias abastadas, que contratavam arquitetos. Não apenas a sobreposição das funções domésticas distinguia as moradias das diferentes classes na cidade. À medida que as habitações das classes abastadas se equipavam com itens importados e se modernizavam, prescindindo de todo trabalho braçal, aumentava o abismo entre essas construções e as destinadas a classes menos abastadas. A vida doméstica - e portanto o espaço doméstico passava por profundas mudanças, que, porém não atingiam a todas as famílias paulistanas. A modernização da cidade e da vida doméstica, como tudo, continuava privilégio de alguns.

A habitação das massas urbanas não era foco de preocupação dos arquitetos - e ainda que o fosse pessoalmente, não havia meios de intervir na questão, devido à estruturação legal e administrativa do município, que responsabilizava o cidadão por sua própria moradia.

A libertação dos escravos e a introdução de mão-de-obra estrangeira, a sofisticação dos hábitos domésticos e a modernização dos equipamentos e atividades caseiras criavam aos poucos hábitos distintos entre si. Os hábitos domésticos paulistanos não se homogeneizavam. 
Um exemplo: nas casas burguesas as zonas de serviço internas seguiam duas direções: de um lado, onde havia influência européia, tais áreas se localizavam junto à moradia principal, sem grande preocupação de distância à zona social; já as que tinham origem local, em que os serviços domésticos estavam ligados à idéia de trabalho escravo, encontravam-se distantes da zona social, como ocorrera com as senzalas. Em alguns casos, mesmo que a dona-de-casa realizasse todos os serviços domésticos, a zona de serviço se encontrava separada da zona social, com entradas, quando possível, separadas.

O agenciamento das casas alterava-se no decorrer do tempo. As zonas de estar, que antes eram locais de estar cotidiano, passavam a se isolar do resto da moradia, apresentando-se em salas individualizadas e nem sempre freqüentadas no dia-a-dia pelos moradores. A copa tornava-se o centro de interesse, nova dependência da morada burguesa, que passava a ser o "diafragma" que separava e unia a área social e de repouso e a área de serviço, onde a cozinha estava localizada, e onde se situavam as principais atividades de lazer - o rádio, o jornal, as conversas.

A morada paulistana não possuía um programa único e uma tipologia única. A herança colonial influenciava profundamente o agenciamento das casas urbanas, com exceção daquelas projetadas por arquitetos europeus. Nas classes médias e populares, a moradia seguia influências coloniais e hábitos trazidos por operários e trabalhadores europeus, além das influências sempre exercidas pelos modelos dos senhores da sociedade, criando misturas contraditórias em sua lógica de agenciamento, com pouco ou nada a ver com a vida doméstica que ali se desenvolvia. 
A influência dos pequenos construtores italianos, espanhóis e portugueses era grande na construção de moradias em bairros populares, sendo capaz de criar uma cultura construtiva homogênea, de grande força e expressão na composição urbana.

São Paulo era a terra das oportunidades trazidas pela riqueza do café, tornando-se uma cidade capitalista e fazendo do solo urbano uma mercadoria:

"Uma das evidências mais imediatas dessas transformações que resultaram na emergência da cidade capitalista foi a apropriação rápida e definitiva que o capital fez do solo urbano. [...] A configuração urbana das cidades modernas é produto, principalmente dos interesses e da lógica da reprodução do capital" (CURY, 2003 apud VILARIÑO, 2006, p. 17).

Essa lógica de construção do espaço urbano levava a um cenário caracterizado por uma malha urbana física e socialmente descontínua.

Os espaços públicos não faziam parte da lógica da construção urbana, em que o solo urbano era visto apenas como capital. A modernização do espaço doméstico, que poderia levar a uma diminuição do espaço privado pela socialização das atividades de lazer, de cultura, de esporte e sociais, não se verificou. O que se constatou foi a diminuição do espaço doméstico privado por uma questão do custo da terra e do adensamento especulativo. Quanto mais popular o loteamento ou empreendimento, mais marcante se tornava a ausência de equipamentos e espaços públicos.

A mudança dos hábitos domésticos e também urbanos não era acompanhada por uma real mudança na estrutura da cidade e nem na forma como esta se expandia, permanecendo determinante a herança de segregação espacial e do uso do solo como reprodução do capital, uso esse que se originara em décadas anteriores, desde o século XIX. 
De origem portuguesa, as cidades coloniais em que houvera intensa atividade comercial ou administrativa e forte atividade econômica, como Recife, Salvador e Belém, possuíam uma tradição urbana infinitamente maior que São Paulo.

Em cerca de 60 anos, a cidade passara de uma vila rural a uma cidade de intensa atividade econômica, moderna e em expansão, sobre uma base urbana colonial. Mais que adaptações à malha existente, houve expansões que exigiam um novo arsenal de conhecimento teórico.

As alterações tanto no espaço doméstico quanto na estrutura urbana ocorriam paulatinamente. O espaço público e o privado iam sofrendo constantes alterações e adaptações. Uma das principais adaptações da malha urbana incidiu sobre os lotes urbanos, que, segundo Goulart (1969), seguia padrões do século XVIII até a metade do XIX. A implantação de residências ao rés do chão deu lugar à construção de porões sobre os quais as casas se desenvolviam em um único piso, com uma resultante elevação em relação à rua que dotava a moradia de uma privacidade então possível apenas nos sobrados. Essa implantação ia passando por variações, assobradando-se, liberando o térreo para as atividades mais nobres da vida doméstica.

Algumas preocupações com salubridade (iluminação e ventilação) começavam a surgir, e a implantação no lote urbano passava por alterações, afastando-se de suas divisas. Ainda com alinhamento à divisa frontal, a moradia ganhou um recuo lateral que mais tarde passaria a constituir-se em um jardim, nas residências mais sofisticadas. O agenciamento interno passava por algumas mudanças:

"A parte fronteira, abrindo para a rua, era reservada para as salas de visitas. Dispunham-se os quartos em torno de um corredor ou sala de almoço [a varanda, que já foi descrita], na parte central, 
ficando cozinha e banheiro ao fundo. Em inúmeros casos, o alpendre de ferro [elemento introduzido na residência quando o acesso se dava pelo jardim lateral] iria funcionar, até certo ponto, como corredor externo. Para eles abririam as portas das salas de visitas e almoço, janelas ou portas de alguns dos quartos, e por vezes, mesmo a porta da cozinha." (GOULART, 1969, p. 46)

Nas moradias mais simples, que não podiam contar com disponibilidade de terreno, as residências apresentam:

"[...] pequenas entradas descobertas, com portões e escadas de ferro. Internamente, lançavam mão de poços de iluminação, aproveitando as facilidades de obtenção de calhas, condutores e manilhas, para controle das águas pluviais e para resolver os problemas dos telhados complicados, decorrentes das novas soluções de plantas. Em todos os tipos, porém, suprimiam-se as alcovas, com evidentes vantagens higiênicas" (GOULART, 1969, p.48).

As chácaras residenciais, afastadas dos centros urbanos, assumiam características cada vez mais urbanas, aproximando-se das residências da aristocracia européia. São Paulo definitivamente transformava-se em cidade, com vida urbana intensa, deixando para trás seu passado rural. A cidade crescia ininterruptamente, porém de forma desequilibrada.

"Foi somente após a supressão do tráfico de escravos, o início da imigração européia, o desenvolvimento do trabalho remunerado e o sistema ferroviário, que apareceram as primeiras residências urbanas com nova implantação, com o que se poderia chamar de 'deslocamento' da construção dos limites do lote e um esforço na conquista e incorporação do espaço externo à arquitetura das residências." (GOULART, 1969, p. 48)

As mudanças no desenvolvimento das habitações, diagnosticadas com grande esforço de pesquisadores, ilustravam a morosidade da transformação nas questões da moradia urbana. A 
velocidade de construção na cidade reforçava o caráter conservador das habitações. Seria possível, com algum otimismo, concluir que não houve o devido tempo para que fosse planejado esse crescimento.

Pretende-se, neste estudo, clarificar a dinâmica com que a questão habitacional foi enfrentada em São Paulo desde o início de sua explosão urbana. O intuito de nos afastarmos das questões sociológicas da habitação é o de aprofundar o olhar na análise arquitetônica e urbana das moradias.

Os profissionais que se ocupam em organizar a cidade, em planejar seu futuro físico, em construir cada uma de suas edificações, em organizar o espaço urbano em que as dinâmicas sociais se desenvolvem ao longo do tempo, devem debruçar-se com grande atenção sobre tais aspectos. Do contrário, continuarão a reproduzir uma realidade que repudiam, mas que não conseguem alterar.

Em uma cidade viciada em passivamente receber influências e modas externas, sem que estas penetrem e se enraízem como cultura urbana em seus moradores, essa atenção deve ser redobrada. 
Identificar os hábitos domésticos herdados dos primeiros tempos da urbanização de São Paulo e verificar se foram ou não preservados, se foram transformados ou não em cultura urbana, configuram o principal objetivo deste capítulo. Entender a dinâmica interna da formação das áreas residenciais e a conformação de suas habitações, procurando afastar-se do efeito segregador que os projetos habitacionais acabaram por exercer ao longo da história, constitui-se inclusive em instrumental para grandes intervenções urbanas.

A conclusão a que se chega é que, mais que transformar hábitos em cultura, iniciou-se a prática de constantes mudanças de hábitos, com assimilação rápida de influências externas que se refletiram nas moradias, na "autoconstrução" enquanto solução individual das questões da habitação, na falta de planejamento do crescimento habitacional, na unidade residencial completamente desconectada de seu contexto urbano e em um programa ou agenciamento interno das moradias que muito pouco tem a ver com a vida que realmente ali ocorre.

A sobreposição de influências, a modernização pontual e lenta e a incapacidade do Estado de orquestrar o crescimento urbano aliado ao econômico criaram um ambiente em que os contrastes e contradições dentro da cidade se tomaram inexoráveis.

O crescimento das atividades econômicas desvinculado da questão da habitação para a massa dos habitantes urbanos teve início no final do século XIX e se tornou uma das grandes características do planejamento urbano paulistano.

As claras diferenças na configuração urbana dos diversos bairros foram cada vez mais se reforçando, tendo como conseqüência perversa o entendimento errôneo de que o crescimento da 
cidade se fez de forma espontânea, sem um controle de fato do Estado. Naquele momento, o Estado se ausentou da dinâmica com que a cidade se construía por meio da habitação.

A grande mudança advinda do sucesso da agroexportação, tendo o café como principal produto, deixou marcas na cidade que ainda hoje se verificam.

Como se verá mais adiante, a dinâmica de crescimento econômico desvinculada de qualquer política habitacional para abrigar as populações trabalhadoras que aportam à cidade tem sido uma constante na cidade de São Paulo há mais de um século. A segregação espacial se reforça a cada período em que, de forma cíclica, São Paulo cresce, se moderniza, corre para o futuro e vai deixando rastros deteriorados por onde passou. Nesse processo não tem havido soma, mas reiteradas exclusões.

O desejo de Modernidade na cidade tem persistido em sucessivos períodos, com conseqüências diversas, ainda que qualquer mecanismo urbano que se tenha tentado utilizar para a organização espacial da cidade tenha na prática apenas protegido o território dos privilegiados e afastado o que poderia ser socialmente incômodo, definindo com precisão os limites de uns e de outros.

Alguns termos têm sido usados incorretamente, como é o caso de "crescimento espontâneo". Como se viu, em nada foi espontâneo esse crescimento. Ele foi direcionado para chegar aonde chegou, proporcionando um pano de fundo para a terceira e quarta décadas do século $\mathrm{XX}$, que trariam ainda mais mudanças. 
A evolução da habitação seguia quantitativamente os passos do crescimento econômico. Crescia em número, mas carecia de um crescimento qualitativo.

Cabe aqui definir alguns termos para darmos continuidade à pesquisa:

Segundo Somekh (1997), a palavra moderno teve origem no final do século $V$, quando o presente se tornava oficialmente cristão, em detrimento do passado romano-pagão.O moderno procura negar o passado, estabelecendo um limite onde começa o presente e se interrompe o passado. A idéia de quebra, de ruptura, de destruição está intrinsecamente presente no conceito de Moderno.

E é moderna que São Paulo se pretendia - e ainda se pretende. O desenho urbano, talvez mais do que o zoneamento, se faz mais do que nunca necessário. A cidade capitalista em que São Paulo se tornou nos primeiros anos do século XX não se importava, no entanto, com a forma que a cidade ia tomando, nem com as relações físicas que iam se estabelecendo.

O baixo nível de renda da população não criava interesse nos empresários imobiliários para que investissem na construção de moradias populares. Nem o Estado procurou aliar-se a eles para produções habitacionais subsidiadas A moradia popular não era uma mercadoria lucrativa para que a indústria da construção civil pudesse ter sido amparada pela Municipalidade (ou pelo Estado, seja em que nível fosse) para que se desenvolvesse - como o foram tantas outras atividades de intervenção urbana, tais como a infra-estrutura. Tampouco o Estado, de forma geral no Brasil, dispunha de recursos para investimento tão grande como o é a habitação para os trabalhadores. 
Esse foi o início de uma dinâmica interna que se manteve inalterada nos períodos seguintes, como se verificará no desenvolvimento da pesquisa. 
Capítulo II

A Modernização da cidade de São Paulo

Assunta Viola 
Este capítulo procura mostrar a forma contraditória como se deu a modernização da cidade de São Paulo, processo esse que apresentou avanços e retrocessos - ou, ainda, avanços em dado momento seguidos, por diversas razões, por forte estagnação, com perda de oportunidades de melhoria geral da qualidade urbana para o conjunto da cidade.

A estrutura urbana herdada dos tempos coloniais e imperiais não comportava a nova dinâmica que se instalava na cidade no fim do século XIX. A expansão da mancha urbana não apenas era necessária, mas em si representava os novos tempos.

"Transformar a cidade não era apenas substituir a vetusta taipa pelo tijolo, trocar beiral aparente pela platibanda ornada. A metamorfose pressupunha romper os limites do sítio de fundação da urbe, transpor as várzeas que cercavam o Triângulo e irradiar a cidade sulcando as periferias com ruas, avenidas e construções, multiplicando a riqueza que circulava com a pujança proporcionada pela preciosa rubiácea." (SEGAWA, 2000, p. 15)

Vários fatores levaram São Paulo a adquirir, dentro da economia cafeeira, uma importância como sede dos barões de café e de toda a economia que girava em torno da atividade agroexportadora, como exposto no Capítulo I. Isso, aliado a acontecimentos externos como a Primeira Guerra Mundial, propiciou condições para a instalação de uma modesta indústria interna.

Melhorias eram necessárias na porção em que se instalavam atividades comerciais e de serviços. Somavam-se a estas as instalações industriais, a habitação da elite que se estabelecia na cidade e, entre os elementos urbanos prioritários. o suporte viário e infra-estrutura para 1998 p. 284) Por isso sua compreensão com os habituais instrumentos de observação não são eficazes. 
"Entre 1800 e 1860, os bairros que começavam a se formar ao redor do velho Centro dispunham-se ao longo dos eixos de saída da cidade: Liberdade, Consolação, Cidade Nova, Luz, Brás, Mooca e Lavapés. Entre esses eixos situavam-se áreas extensas, ocupadas com chácaras, pouco acessíveis para residências permanentes. ${ }^{\prime \prime}$ (REIS, 2004, p. 128)

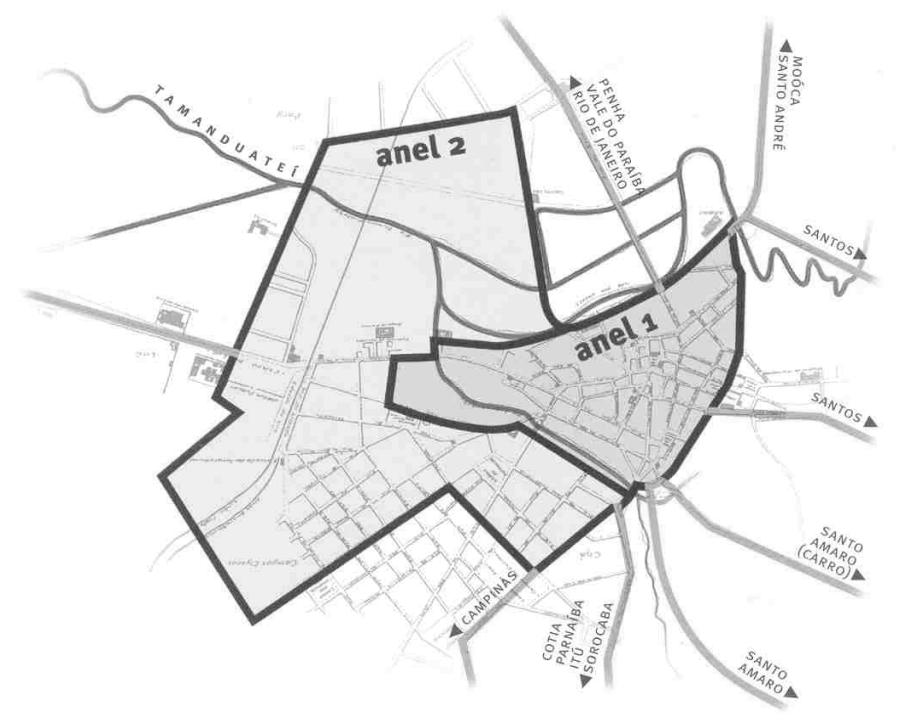

Fig. 8 - Traçados das novas ruas entre 1880 e 1860, formando dois anéis ao redor do centro urbanizado, já indicando eixos de crescimento rumo às periferias (REIS, 2004). 


\subsection{A construçăo dos espaços intraurbanos}

A segregação espacial e social, iniciada já nas primeiras fases da expansão urbana, tornava-se uma dinâmica caracterizadora do desenvolvimento na cidade.

A partir das últimas décadas do século XIX, São Paulo passava por grandes modificações, procurando inserir-se em padrões urbanos mais modernos que simbolizassem seu crescimento econômico. Isso ocorria nas áreas centrais da cidade, que já se localizavam serviços e comércio e para onde novos desses estabelecimentos era atraídos através de intervenções pontuais, como por exemplo, a construção do primeiro Viaduto do Chá, em 1892, e, na primeira década do século XX, do Viaduto Santa Ifigênia (1906), ambos projetos suntuosos que visavam espelhar o fim do provincianismo local ${ }^{5}$

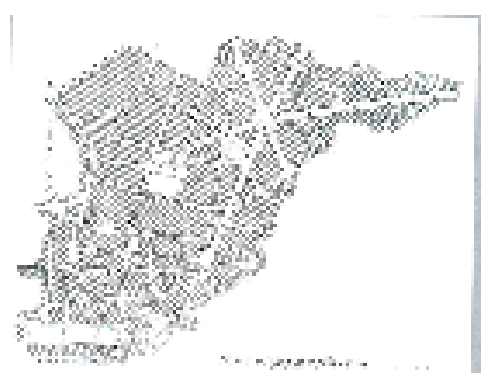

Fig. 9 - Planta do Projeto Alexandre de Albuquerque, 1910 (SEGAWA, 2004)

A partir de 1890, várias sociedades anônimas ligadas à construção e loteamentos proliferavam, com a instalação de infraestrutura, escolas, hospitais, e equipamentos de lazer (SEGAWA, 2004, p. 27).

"A modernização da cidade tinha além de seu aspecto prático e funcional uma forte carga simbólica: 'O império havia se caracterizado pela valorização do mundo agrário e pelo apoio ao sistema de trabalho escravo. [...] Para acentuar o atraso da monarquia, os republicanos empenharam-se na valorização do urbano, em uma ampla modernização técnica e social. Na época isso correspondia a copiar as reformas urbanísticas das cidades européias, em especial de Paris." (REIS, 2004, p. 139)

Os conceitos na área de planejamento urbano referentes aos espaços intraurbanos são necessários para se estabelecer o cenário em que os projetos habitacionais foram construídos. Sem

\footnotetext{
5 Sobre os projetos e planos urbanos mais importantes do final do séc. XIX e início do XX, ver Prelúdio da metrópole: arquitetura e urbanismo em São Paulo na passagem do século XIX ao XX, de H. Segawa (2. ed. São Paulo: Ateliê, 2004).
} 
esse entendimento, o estigma da arquitetura produzida para conjuntos habitacionais e áreas periféricas não pode ser demolido. A idéia de que "o trabalho útil concreto produz valores de uso em determinados lugares" (HARVEY, 1932, apud VILLAÇA, 2001, p. 22) e de que portanto há dois tipos de espaços, "o dos objetos em si (produzidos ou não pelo trabalho humano) e aquele determinado pelos locais onde estes são produzidos e consumidos" (VILLAÇA, 2001, p. 23), é fundamental para se compreender a diferença arquitetônica entre os diversos bairros da cidade.

Esses conceitos à "periferização" do crescimento na cidade, já descrita. Se "localização urbana é [...] aquela na qual as relações não podem existir sem um tipo particular de contato: aquele que envolve deslocamentos dos produtores e dos consumidores entre os locais de moradia e os de produção e consumo" (VILLAÇA, 2001, p. 23), tais localizações indicam os caminhos que o crescimento urbano tomava em São Paulo e a conseqüente segregação oriunda do sistema colonial da estruturação da sociedade brasileira, fortemente influenciada pela escravidão. Vale lembrar que 
Em São Paulo o cenário de pobreza se misturava com o da miséria urbana, embora o acúmulo de capital, demanda de serviços e atividades geradas na cidade fosse o maior do país. ${ }^{6}$

São Paulo ia adquirindo importância à medida que sua economia ia se desenvolvendo. A chegada da ferrovia, de 1867 a 1875, fazia a cidade um importante centro ao unir o interior agrícola ao porto de Santos, promovendo maior expansão urbana. São Paulo era a cidade aleita para sediar as casas dos fazendeiros de café e toda a estrutura administrativa ligada ao comércio de importação e exportação. A imigração européia e a Primeira Guerra Mundial criavam condições para a instalação de uma indústria local.

Alguns fatores levaram a que:

"[...] três agentes municipais atuassem na configuração urbana: a municipalidade, no atendimento dos interesses da economia cafeeira e da classe oligárquica; as empresas de infraestrutura e as empresas imobiliárias privadas. A legislação urbanística desse período tentará acomodar os vários interesses. [...]

Fig. 10 - [cancelada]

${ }^{6}$ Para maior aprofundamento sobre o conceito de espaço intraurbano, consultar VILLAÇA, F. - Espaço intraurbano no Brasil São Paulo: Studio Nobel/FAPESP/Lincoln Institute, 2001 p.17-48 


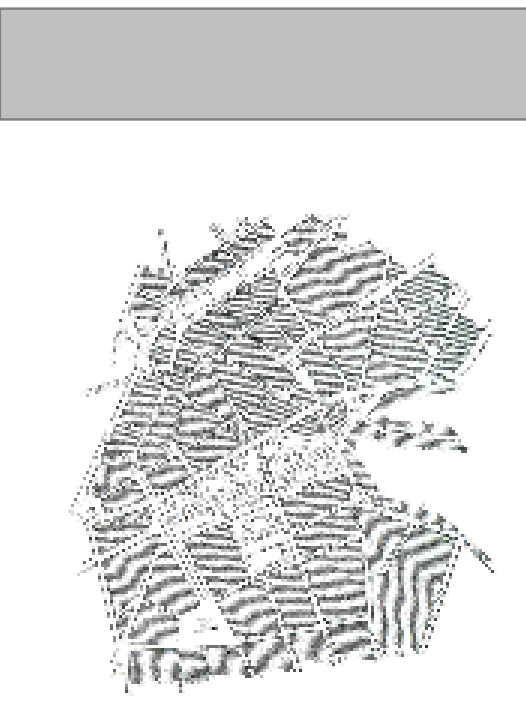

Fig. 11 - Planta do projeto FreireGuilhem, 1911 (SEGAWA, 2004)

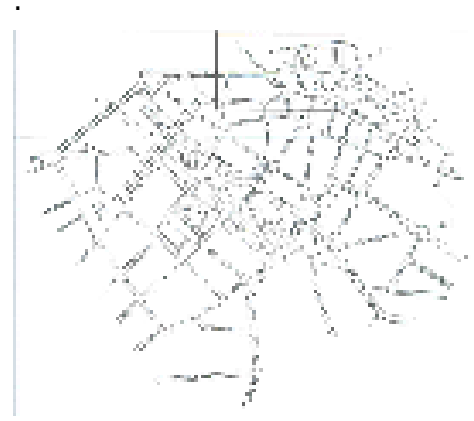

Fig. 12 - Planta do projeto FreireGuilhem - detalhe, 1911(SEGAWA, 2004)
Leis urbanas eram criadas para proibir usos e habitantes indesejáveis na área central [...] e leis municipais prescrevem padrões mínimos de habitabilidade para casas operárias e isentam de impostos quando construídas fora do perímetro urbano central.

A legislação que proíbe certos usos em determinados locais configura o rudimento de um zoneamento, que irá evoluir ao longo do tempo [...] configura-se como solução aos problemas específicos e localizados da elite paulistana." (VILARIÑO, 2006, p. 15-16, 19)

A cidade no final do século XIX é assim descrita por Vilariño:

"[...] núcleo central - colina histórica - abrigando as funções comerciais e administrativas da cidade; loteamentos de elite e de padrão médio nas direções oeste e sudoeste; bairros populares e unidades fabris junto às ferrovias e várzeas inundáveis na direção norte e leste; mais ao longe, loteamentos e núcleos periféricos que iriam prosperar a partir de 1890." (CAMPOS, 2004, apud VILARIÑO, 2006, p. ...)

Enquanto isso, nas áreas mais centrais, entre 1910 e 1919 três projetos de melhoramentos eram expostos em São Paulo, criando polêmica a ponto de se recorrer ao arquiteto francês Joseph Antoine Bouvard para um parecer final.

O Projeto Alexandre de Albuquerque reforçava a centralidade ao propor três avenidas convergentes sobre malha urbana existente, que se encontrariam na Praça Antônio Prado, garantido aos investidores exploração imobiliária ao longo das novas avenidas, sendo a municipalidade responsável pelo prolongamento das redes de água e esgoto e da iluminação de 
Embora de caráter "haussmanniano", o plano de Albuquerque propunha o abandono do Triângulo tradicional, procurando um novo espaço de articulação com as antigas e novas referências urbanas, com forte ênfase na transposição do vale do Anhangabaú.

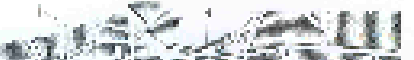

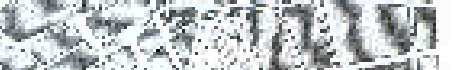

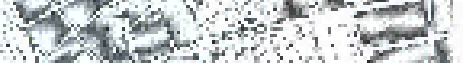

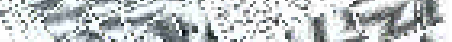

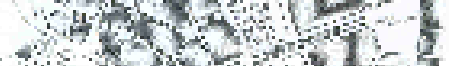

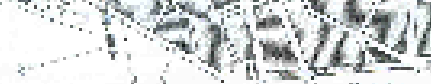

Fig. 14 - Planta do projeto Samuel das Neves, 1911 (SEGAWA, 2004).
O Projeto Freire-Guilhem procurava articular a estrutura urbana paulistana, de caráter colonial, à nova dinâmica urbana imposta pelo crescimento explosivo da cidade, dentro de um espírito cosmopolita. A principal característica do projeto era que procurava organizar a cidade no espírito do "circuito exterior", com a criação de um anel de circulação em torno ao núcleo significativo da cidade: o centro (dentro do anel) e a periferia (fora deste).

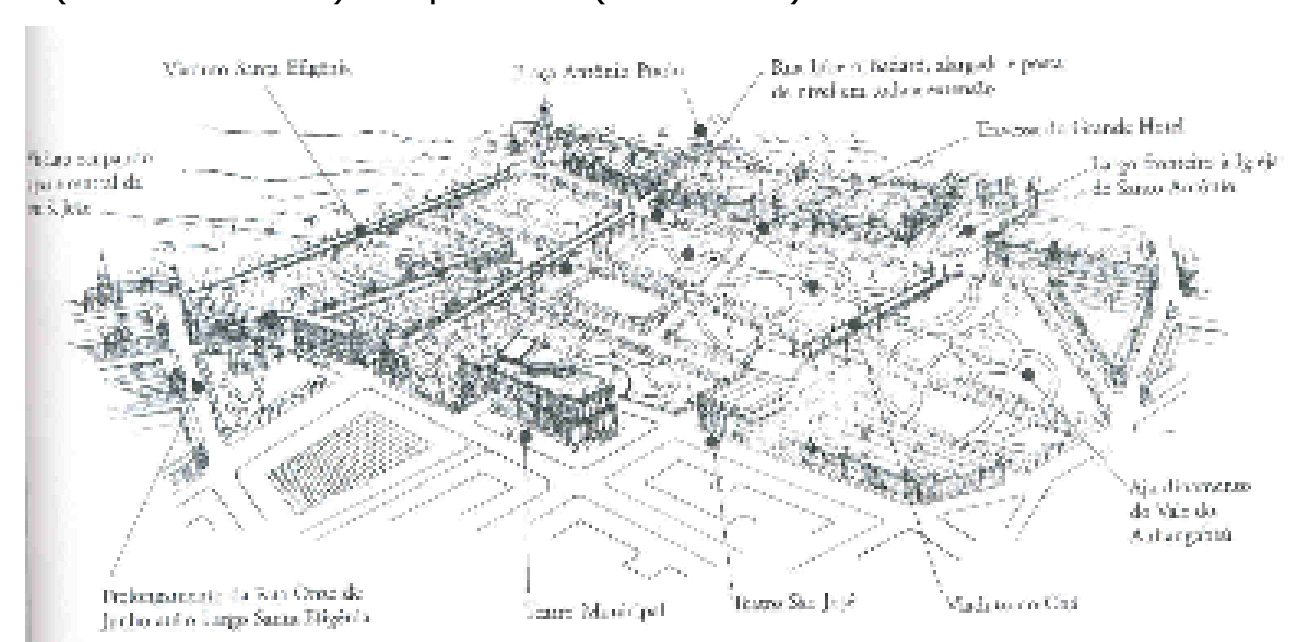

Fig. 13 - Perspectiva do projeto Freire-Guilhem, 1911 (SEGAWA, 2004) 


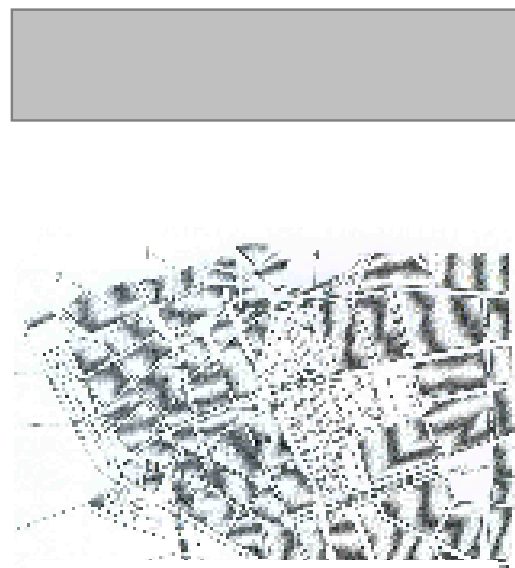

Fig. 15 - Planta do projeto Samuel das Neves, 1911 (SEGAWA, 2004).

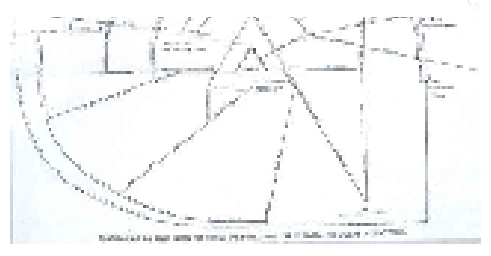

Fig. 16 - Esquema de circulação, conforme recomendações de Bouvard, 1911 (SEGAWA, 2004)

\section{O Projeto Samuel das Neves}

Os principais pontos do plano eram a construção de pontes que venciam o vale do Anhangabaú na direção oeste; o alargamento de vias internas junto ao Triângulo ${ }^{7}$; a abertura de vias largas que ligavam o centro ao norte, até o rio Tietê; o adensamento construtivo junto à rua Libero Badaró e à avenida Anhangabaú, propostas; a abertura de praça junto à igreja de Santo Antônio; alargamento da rua do Grande Hotel; abertura de via ligando o largo São Francisco à rua da Quitanda com rua do Comércio; construção da ponte da rua Boa Vista, ligando o largo São Bento ao pátio do Colégio.

\section{O Plano Bouvard}

Em seu plano, Bouvard empreendia uma leitura mais ampla da cidade, entendendo-a como área urbanizada e área em expansão, considerando sua topografia e as características das implantações urbanas (conjuntos construídos já implantados e as relações físicas e hierárquicas entre eles) e de parcelamento (a divisão do território em quadras, ruas e lotes). Seu plano não

7 O Triângulo consistia no primeiro núcleo urbano na cidade de São Paulo, que era delimitado pelas Igrejas de São Bento, de São Francisco e do Carmo. 


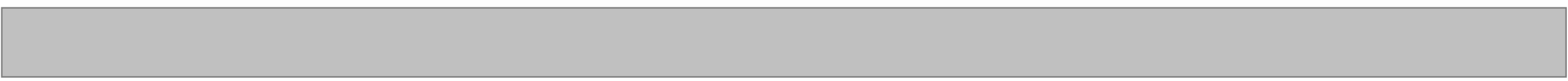

apenas organizava a malha existente, mas a integrava à malha em ampliação, propondo recomendações de acordo com estudos feitos sobre a realidade física e social observada.

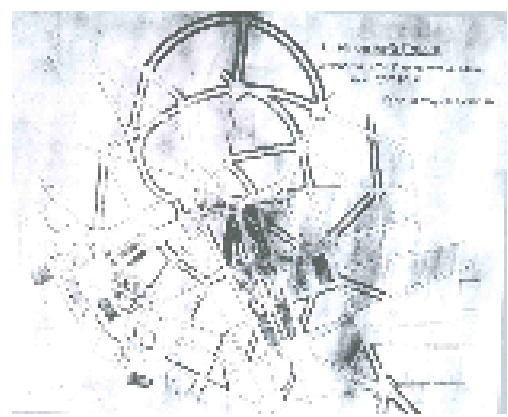

Fig. 17 - Modificações previstas para o centro, conforme recomendações de Bouvard, 1911 (SEGAWA, 2004).

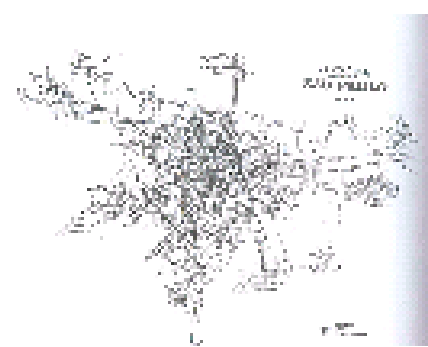

Fig. 18 - A mancha urbana de São Paulo em 1909 (SEGAWA, 2004).
"Sucede que, como conseqüência do solo, naturalmente, por assim dizer, a cidade alastra-se exageradamente, com grande prejuízo das finanças municipais, pelos espigões das colinas fáceis de alcançar, sem que as construções se estendam pelos vales, mais dificilmente acessíveis. [...]

É necessário [...] enveredar pelas linhas convergentes ou envolventes, conforme os casos. Uma vez posto em prática [...] as ruas de parcelamento podem, sem inconveniente, tomar qualquer direção que Ihes seja indicada pelo interesse dos proprietários.

Temos como conseqüência: para o centro, para o Triângulo, para a Urbs, respeito do passado, inutilidade de rasgos e de alargamentos exagerados. [...] Considero efetivamente possível descongestionar o centro comercial, de lhe melhorar certos aspectos, dali regularizar o movimento e a circulação, por meio de processos de derivação das correntes para as vias envolventes de fácil comunicação.

Para a periferia adota-se a circulação por meio de novas distribuições em anfiteatro [...]. Estabelecida esta preliminar, a solução do problema acha-se subordinada aos dados seguintes: Obter desafogo do centro, pelo retoque de algumas partes internas e pelo estabelecimento de comunicações, largas, fáceis e diretas, segundo seu contorno;

Pôr em evidência e observar [...] pontos de vista mais notáveis, interiores e exteriores;

Criar aos edifícios públicos [...] uma vizinhança que os faça pôr em relevo e corresponda ao custo da sua construção;

Assegurar o desenvolvimento da cidade em condições normais e racionais. [...] 
Mais a população aumentará, maior será a densidade de aglomeração, mais crescerá o número de construções, mais alto subirão os edifícios, maior se imporá à urgência de espaços livres, de praças públicas, de squares de jardins, de parques, se impõe." (BOUVARD, 1911, apud SEGAWA, 2004, p. 9697)

"O plano de Bouvard tinha como característica principal a capacidade de conciliar a evidente qualidade de seu trabalho paisagístico com igualmente evidentes interesses imobiliários de várias famílias." (REIS, 2004, p. 183)

Delineava-se a partir daí uma característica que se tornaria permanente na administração e construção urbanas em São Paulo.

"Mesmo que houvesse um desejo potencial por parte do poder público para assumir obras de embelezamento urbano, somente a iniciativa privada arriscava recursos financeiros para tais empreendimentos, oferecendo propostas articuladas segundo os seus interesses. Essa situação tornarse-ia o paradigma das limitações do poder público e da atuação do empreendimento privado na evolução da cidade de São Paulo até hoje." (SEGAWA, 2004, p. 58)

"No início de 1890, São Paulo teria 65.000 habitantes. Era o centro de um sistema regional de cidades, mais ou menos limitado no sentido oeste. [...] Nos 40 anos seguintes, seriam amplas as mudanças. Em 1930, a cidade de São Paulo alcançava 900.000 habitantes. [...] A base da economia já não era apenas a comercialização da produção agrícola do estado, mas também a de sua produção industrial. [...] A cidade impunha-se como um pólo de produção, de distribuição industrial e de comércio." (REIS, 2004, p. 141)

O grande e rápido crescimento populacional da cidade era um dos maiores desafios que 0 município tinha a enfrentar. A questão habitacional, em termos de projeto arquitetônico e construção de ofertas habitacionais, era ignorada, embora a cidade, expandindo-se em pontos 
comerciais, em serviços, em avenidas, em monumentos, em pontes, crescia fundamentalmente em pessoas, distribuídas em atividades, raças, camadas sociais, níveis educacionais e culturais os mais diversos.

Seguindo padrões europeus de urbanização - fossem eles mais conservadores ou mais inovadores - , a questão de habitação das camadas urbanas que se avolumavam passava ao largo das preocupações da administração pública. Essa característica foi se enraizando a ponto de a carência habitacional parecer inerente ao subdesenvolvimento.

Por estar diretamente ligado aos movimentos de industrialização das cidades européias, o Movimento Moderno, ou Modernismo - movimento artístico (e social) das últimas décadas do século XIX - procurava entender as mudanças advindas da sociedade industrial e, de forma absolutamente revolucionária, construir uma arte, uma arquitetura e um urbanismo que expressassem essa nova sociedade.

Como um conjunto de idéias de alcance social, o Modernismo, caracterizado principalmente por propor (1) o progresso linear, (2) as verdades absolutas, (3) o planejamento racional das ordens sociais ideais e (4) a padronização e estandardização da produção (SOMEKH, 1997), foi um dos mais importantes movimentos culturais com reflexos intensos na estrutura urbana das grandes cidades mundiais. Teve uma produção expressiva de habitações nas cidades industriais européias até a década de 1950, atendendo a demanda criada pela industrialização e a demanda criada pelas duas grandes guerras mundiais. Incluía-se entre seus princípios o atendimento habitacional das massas urbanas, dentro de critérios rigorosos de urbanismo e arquitetura - prática que no Brasil 


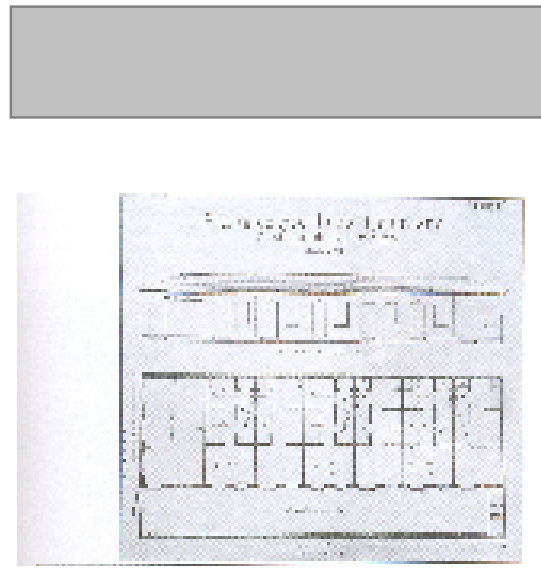

Fig. 19 - Planta de cortiço, 1893 (BONDUKI, 1998). nunca se concretizou de modo efetivo, já que necessariamente se deveria contar com intervenção decisiva do Estado, que, como se viu, em São Paulo não tinha essa preocupação.

Essas idéias chegariam ao país por outro viés, alguns anos mais tarde.

As intervenções efetivadas e aquelas pretendidas pelo conjunto dos políticos e técnicos municipais tinham por objetivo intervir apenas nas áreas destinadas aos capitalistas paulistanos, concluindo-se daí que:

1. as melhorias no centro antigo não levavam em conta a questão habitacional na escala em que o crescimento populacional avançava;

2. mesmo a expansão dos bairros de famílias de renda mais alta não era planejada no conjunto da cidade, sendo os loteamentos formulados com bases mais especulativas que urbanísticas;

3. mesmo os planos que levavam em conta a questão da periferia, como o Plano Bouvard, não aprofundavam a forma de ocupação dessas áreas, limitando-se a descrever a inserção das periferias por meio de esquemas de circulação no plano geral - sem dúvida, porém, um passo à frente dos demais planos, em que os instrumentos de desenho urbano davam forma à cidade apenas nas áreas centrais.

Os primeiros loteamentos implantados na periferia, segundo Segawa (2004), datam do século XIX e se eram localizados de forma a se separarem da malha consolidada, exigindo um prolongamento da infra-estrutura, criando vazios urbanos que se prestavam à especulação imobiliária. 
A expansão periférica era impelida pela moradia: os loteamentos para as classes mais altas situavam-se num anel periférico ao redor do centro, enquanto os destinados às classes mais baixas situavam-se em locais distantes e desprovidos de infra-estrutura, estabelecendo-se assim grandes vazios urbanos entre os dois âmbitos, demandando uma constante expansão da infraestrutura e de equipamentos urbanos. Essas terras vazias entre os dois âmbitos, atendidas pela infraestrutura que abasteceria os bairros periféricos, seriam valorizadas, criando especulação imobiliária, aumentando o preço da terra como mercadoria e mantendo afastadas as camadas que não tinham condições de pagar.

Segawa (2004) considera terem sido duas as periferias que surgiam no fim do século XIX e início do século XX: a Periferia Saudável e a Periferia Remediada. 


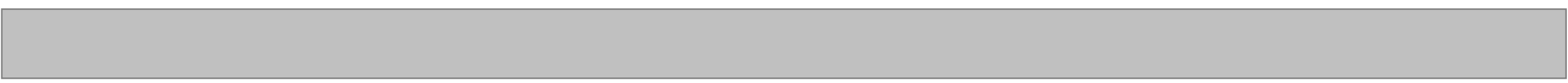

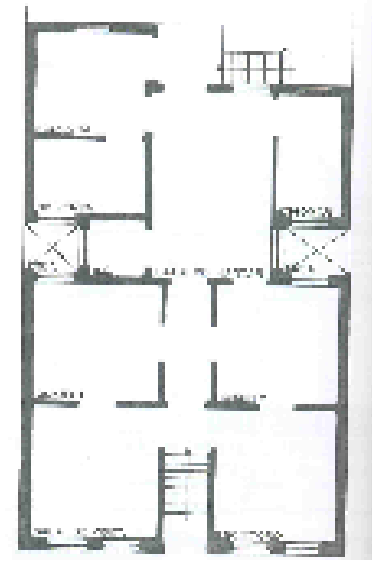

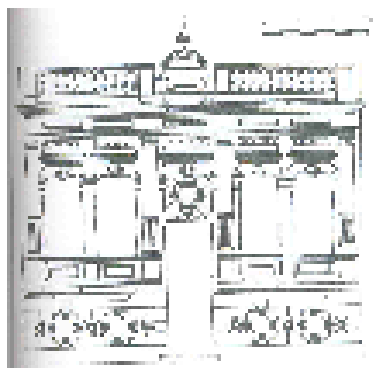

Fig. 20 - Residência construída em 1896. O projeto tentava obedecer às exigências legais de iluminação natural dos cômodos (LEMOS, 1999).
As periferias abrigavam habitações em loteamentos promovidos por capitalistas imobiliários. A habitação era periférica ao centro comercial, no qual se concentravam os serviços e comércio, além da administração pública, havendo assim um fluxo radial de pessoas, serviços e mercadorias. Dentro do esquema funcional, a cidade se setorizava em áreas especializadas de serviços, comércio, indústria, habitação de famílias de renda mais alta e habitações populares.

Carlos Lemos descreve a São Paulo do período:

"Cidade encortiçada, suja e malcheirosa. Cidade que, de repente, passou a conhecer o programa habitacional inusitado, ou melhor, até então desconhecido: famílias diversas morando em promiscuidade, usando as mesmas instalações sanitárias e lavando roupa suja nos mesmos tanques. [...] a palavra cortiço significa a casa das abelhas, com seus alvéolos repetidos à exaustão; e as primeiras construções aproveitando os fundos dos grandes quintais, onde havia a repetição monótona de cubículos, passaram a receber, também, aquela denominação. A expressão logo se estendeu a todo tipo de habitação coletiva que possuísse áreas de uso comunitário." (LEMOS, 1999, p56)

Esses cortiços implantavam-se como minúsculos cômodos (ou por vezes com agregados de dois ou três cômodos) enfileirados ao longo de corredores estreitos e descobertos, laterais ou centrais, tendo ao fundo latrinas e tanques (LEMOS, 1999). 8

${ }^{8}$ Para informações mais detalhadas sobre o modo de vida popular em São Paulo no final do séc. XIX e início do séc. XX, ver o capítulo "A habitação popular, ou melhor, a casa operária", em Cozinhas, etc., de Carlos Lemos (São Paulo: Perspectiva, 1978). 
Simultaneamente, o cenário que se apresentava nos investimentos públicos era o de grandes obras na área central, com modernizações urbanas, diversificação das atividades econômicas trazidas pela economia agroexportadora - e portanto diversificação nos equipamentos comerciais e de serviços, com a construção de edifícios destinados a esse fim - , aumento drástico da população em número e em diversidade cultural, introdução de hábitos urbanos de cunho mais popular - em contraste com as pretensões européias das classes mais abastadas - , ausência de políticas públicas habitacionais para o contingente populacional em crescimento e, além disso, população que apresentava cada vez mais características da sociedade industrial, ainda que as comodidades da vida urbana não se distribuíssem a todos.

As habitações iam sendo construídas sob regulamentação de leis urbanas que visavam mais propriamente distanciar o que não interessava às classes dominantes do que estabelecer uma política urbana capaz de organizar o crescimento.

"O Código de Posturas de 1886 proibia cortiços e estabelecia novos padrões edilícios que foram sendo posteriormente alterados por novas legislações (Código de Obras de 1920, 1929 e 1934); o Código Sanitário de 1894 e leis municipais prescrevem padrões mínimos de habitabilidade para casas operárias e isentam de impostos quando construídas fora do perímetro urbano central." (VILARIÑO, 2006, p. 19)

Os imigrantes eram personagens fundamentais na arquitetura das habitações localizadas nas áreas centrais. Nas últimas décadas do século XIX os alemães exerceram intensa atividade 

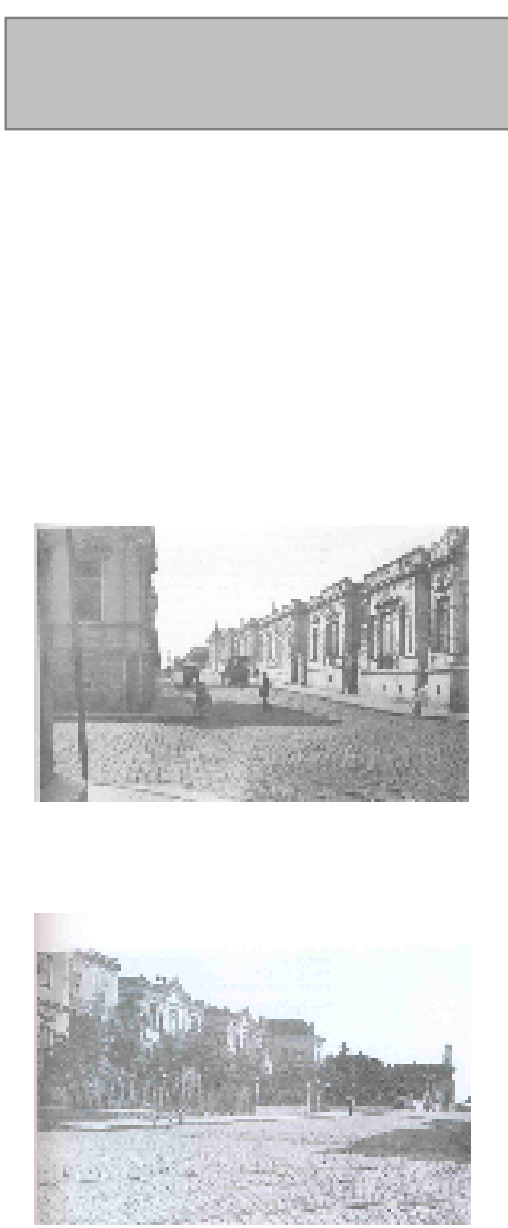

Fig. 21 e 22 - Casas de aluguel, 1900. Fonte: Fundação Patrimônio Histórico da Energia de São Paulo (LEMOS, 1999). imobiliária, abrindo loteamentos, como por exemplo os Campos Elíseos. Obras residenciais importantes eram construídas por alemães, como a casa do Conde Eduardo Prates, a casa da família Paes de Barros, a da família Nothmann e a da família Elias Chaves, que depois se tornaria sede de governo (LEMOS, 1978, p. 127-128), mas todas atendiam às camadas mais ricas da população.

Os italianos também eram construtores importantes naquele final do século, como exemplificam a Chácara do Carvalho, de propriedade do Conselheiro Antônio Prado, construída por Luigi Pucci, e a casa dos Matarazzo, obra de Giulio Santini e Luigi Marconi.

As habitações das classes médias guardavam ainda forte ligação com o passado colonial, com uma mistura deste com a influência que as classes mais abastadas exerciam sobre os hábitos dessa população.

Quanto às classes menos favorecidas, alojavam-se da maneira mais precária, em habitações A alta do preço da terra levava a soluções mais adensadas, embora estas não fossem bem aceitas no início.

"A diminuição do poder aquisitivo, os aumentos de população e a saturação das zonas centrais fizeram surgir os dois caminhos a seguir: ou o indivíduo da classe média optava pelo pequeno chalet, ou bungalow, ou sobradinho geminado nos bairros afastados, longe do local de trabalho, ou aceitava o apartamento bem situado, aceitava o prédio de habitação coletiva... [...] assim, nas zonas centrais das cidades boas ficaram, lado a lado, os estabelecimentos comerciais, os escritórios, as repartições públicas, os velhos casarões transformados em cortiços, em pensões ou em hotéis e a última aquisição urbana brasileira, o prédio de apartamentos, inicialmente planejado e construído sem critério normalizador [...] 


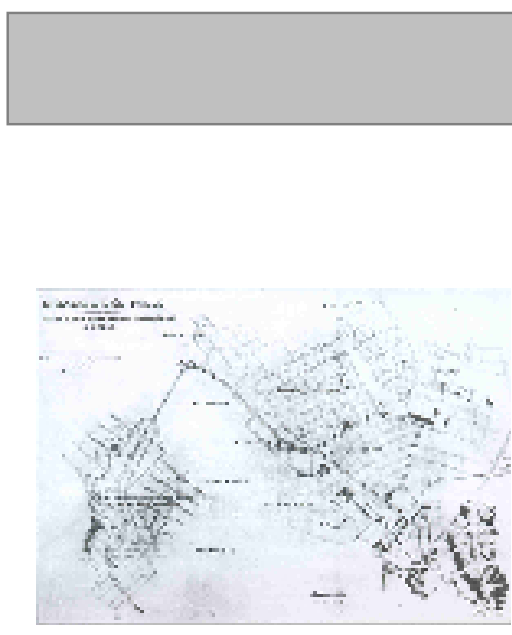

Fig. 23 - Parte do Plano Bouvard. Note-se a extensão da cidade a oeste, em direção ao Jardim América (SEGAWA, 2004).

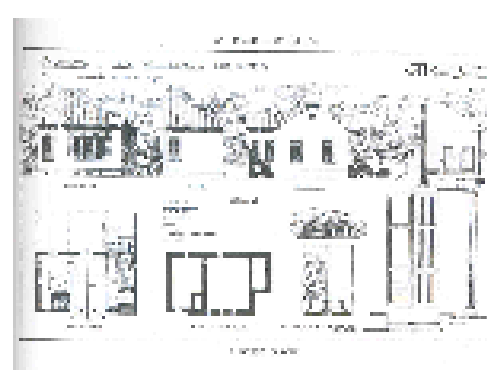

Fig. 24 - Projetos de casas proletárias econômicas, concurso de 1916 (SEGAWA, 2004).
No começo, apartamentos alugados; depois, por volta de 1948, apareceu a febre do condomínio." (LEMOS, 1978, p. 154-155)

Ao se ausentar da responsabilidade de prover moradia à população com a formulação de uma eficiente política habitacional, ao poder público restava o papel de alinhavar essas realidades sociais e espaciais diversas implantando infraestrutura e equipamentos institucionais. No entanto, a concentração dessas intervenções decrescia do centro à periferia.

A célula residencial passava por revisões periódicas junto às famílias de renda alta. Os conceitos mais modernos da época eram aplicados sempre junto a essas famílias, mesmo que em sua origem tais conceitos não tivessem uma conotação sofisticada e elitista, fazendo parte, em vez disso, de conceitos urbanos ligados à cidade industrial que se desenvolviam na Europa desde o século XIX.

Esse conjunto de fatores, com características distintas e qualificações diversas, resultava no entanto em um aumento do bem-estar, gerado pela industrialização, que trazia notáveis modificações urbanas: "o novo urbanismo se caracterizou pela modernização da infraestrutura dos serviços, pela europeização da aparência de alguns bairros e a completa reconstrução do novo centro. A modernização técnica foi estendida em parte aos bairros operários, com as linhas de eletricidade, com a instalação de grupos escolares e alguns serviços de saúde pública" (REIS, 2004, p. 144).

A paisagem urbana ia tomando aspectos inéditos. Mesmo a região central apresentava diversas configurações: o Triângulo primeiramente; o vale do Anhangabaú; os bairros equipados para as 
classes mais altas, a oeste; as freguesias que se localizavam em todas as direções, deixando grandes vazios urbanos até o centro. Áreas afastadas, como o loteamento popular Gomes Cardim, de 1897, situado na zona leste, atual distrito do Tatuapé (PONCIANO, 2001), já começavam a povoar as periferias então distantes.

A aplicação de teorias urbanísticas, oriundas das grandes cidades européias, na expansão da malha urbana tinha mais propriamente sentido mercadológico, com loteamentos para as classes mais altas - e não de desenho urbano integrado - , de iniciativa predominantemente privada.

A cidade-jardim 9 foi trazida pela City of San Paulo Improvements and Freehold Land. Co., Ltd., organizada em Londres com um corpo de 14 diretores, que incluíam Bouvard, Cincinato Braga,

Extensos terrenos eram adquiridos na zona oeste da cidade, originando a City Pacaembu e a City Lapa. O Jardim América era o primeiro bairro construído pela Cia. City, projetado por Barry Parker e Raymond Unwin, arquitetos realizadores da primeira cidade-jardim em Letchworth, Inglaterra.

Na época, o automóvel possibilitava, por fim, o acesso a lotes situados fora do centro, permitindo a rápida multiplicação de loteamentos City pela cidade, contribuindo para sua expansão periférica, fazendo de São Paulo uma "concha de retalhos" das mais diversas tipologias e morfologias urbanas.

9 "Ebenezer Howard e Frederick Law Olmstead foram os grandes pensadores da concepção urbanística Cidade-Jardim [...]. Contudo, é na obra de Raymond Unwin e Barry Parker que encontraremos os princípios do tipo cidade-jardim aplicados exemplarmente. [...] Letchworth (1903), a primeira cidade-jardim inglesa." (TREVISAN, 2001). 


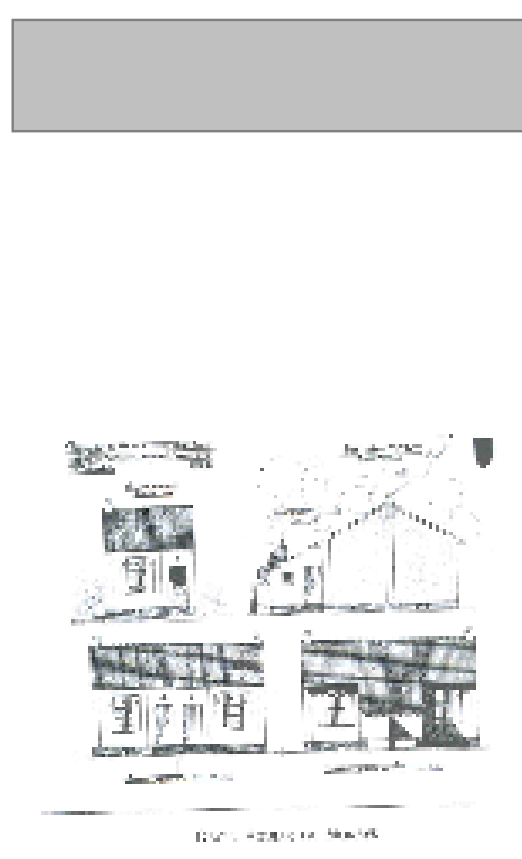

Fig. 25 - Projetos de casas proletárias econômicas, concurso de 1916 (SEGAWA, 2004).
A fim de manter condições mínimas de habitabilidade nas residências populares e operárias, a municipalidade, em 1916, promovia uma concorrência pública de projetos de casas proletárias econômicas para uma só família. Os projetos deveriam satisfazer as seguintes condições: higiene, comodidade, estética e economia. Eram quatro as tipologias solicitadas:

1. edificações formando blocos de quatro moradias, contíguas entre si por duas faces normais;

2. edificações formado "série", contíguas umas às outras por faces paralelas;

3. edificações geminadas, em que cada moradia oferecia uma só parede comum com uma das vizinhanças;

4. edificações completamente isoladas.

Essa iniciativa pretendia fazer um estoque de projetos-padrão que estavam em conformidade com as posturas legais (código sanitário, leis e atos municipais), tendo como principal preocupação o aspecto higiênico da habitação.

As iniciativas municipais reforçavam o caráter segregador de localização das habitações populares. Num primeiro momento, as técnicas construtivas e materiais não variavam muito em relação àqueles utilizados nos bairros "nobres". Apenas se diferenciavam pelas dimensões e ,principalmente.

O acanhamento com que a questão habitacional era tratada resultou em medidas frágeis para evitar a explosão dos problemas habitacionais que ocorreriam na década de 1920.

O Código Arthur Saboya, de 1929, definia casa operária (que dispensava alvará de construção), habitação popular e habitação residencial, que se diferenciavam pelo número de cômodos. 
A segregação espacial das áreas operárias e populares já se podia verificar a partir do banimento imposto a essas habitações no "Código Sanitário do Estado de São Paulo de 1894 ('as vilas operárias deverão ser estabelecidas fora da aglomeração urbana'), e bem antes, no Padrão Municipal de 11 de agosto de 1886, dedicava-se em um mesmo capítulo prescrições comuns a 'cortiços, casas de operários e cubículos', todos 'proibidos no perímetro do Comércio'"' (SEGAWA, 2004 , p. 161 ${ }^{10}$, afastando essa população não só da mancha urbana equipada, mas da vida urbana.

A questão do custo da terra, uma das fortes justificativas para a periferização das moradias das classes operárias não figurava como determinante de mercado. O poder público não era capaz de uma visão urbana abrangente, do funcionamento urbano como um todo, visão desenvolvida pelos precursores do Movimento Moderno, o qual, apesar de propor uma criticável setorização urbana por usos, preconizava para o sistema urbano um funcionamento global a fim de viabilizar as atividades industriais e a cidade industrial. Os conflitos sociais se apaziguavam (ao menos aparentemente) a medida que as classes eram segregadas espacialmente. A já conhecida dicotomia da vida urbana e da vida rural ganhava um novo personagem: o homem urbano remediado, que não tinha a autosuficiência da vida rural, nem as facilidades da vida urbana. Vivia entre uma e outra, de certo modo alijado de ambas, em uma vida urbana pela Algumas tentativas isoladas eram empreendidas para a moradia da classe operária, insuficientemente fortes, porém, para alterar a realidade urbana que se

${ }^{10}$ Em Prelúdio da metrópole (2. a edição, São Paulo: Ateliê, 2004), Hugo Segawa analisa mais detalhadamente questões da legislação e da segregação espacial em São Paulo nessa época. 
configurava e consolidava nessas primeiras décadas do século XX. A experiência de Jorge Street, na Vila Maria Zélia, que criava uma vila operária junto ao complexo industrial de que era proprietário, equipada com hospital, escola, igreja - um dos exemplos das iniciativas pontuais promovidas pela

\section{iniciativa privada.}

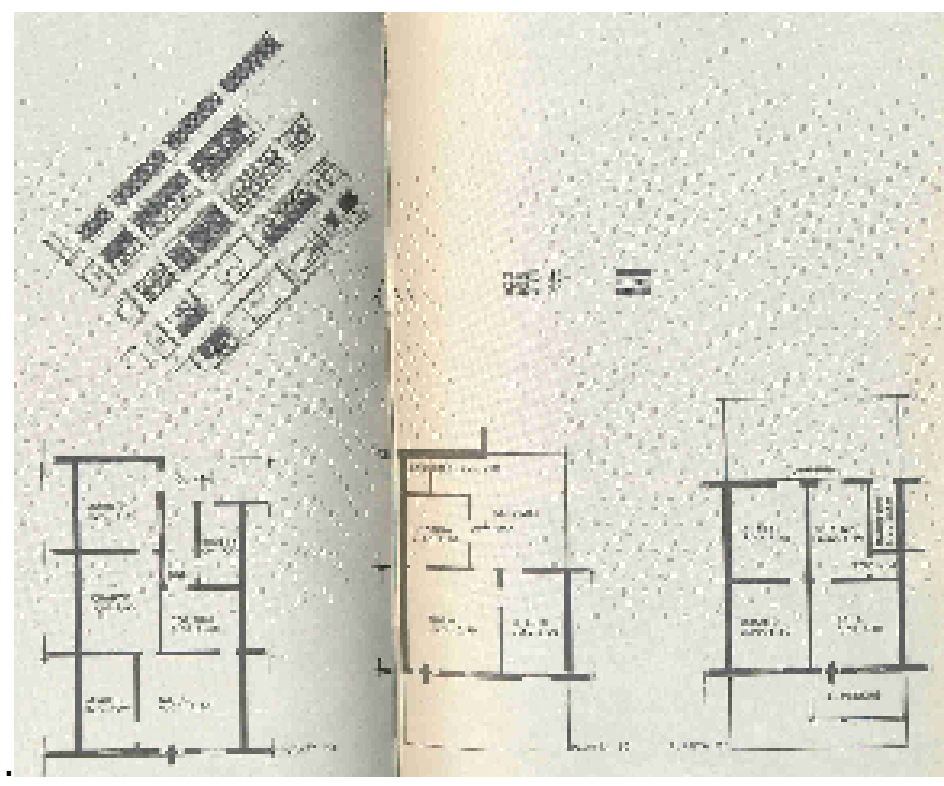

Fig. 26 - Vila Zélia, conjunto de casas operárias (LEMOS, 1978). 


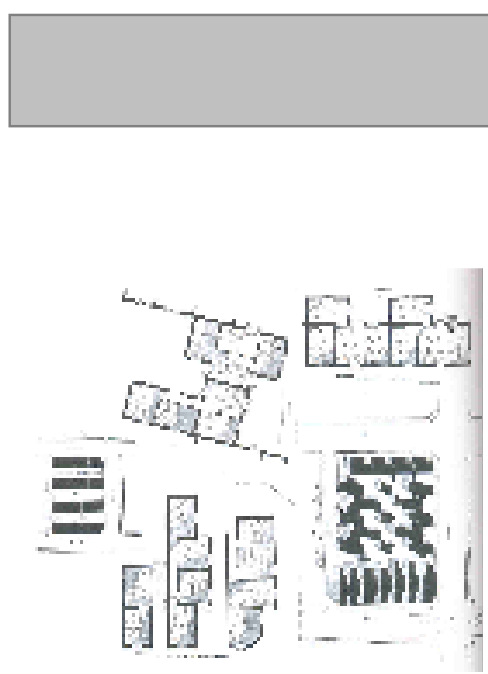

Fig. 27 - Projeto de Alexandre de Albuquerque para casas proletárias econômicas, em que há preocupação com insolação e implantação (concurso de 1916) (SEGAWA, 2004).
A urbanidade era aspecto inédito tanto na vida da cidade quanto na de seus habitantes. Vários aparentes contra-sensos ainda se verificavam, como os elementos de auto-suficiência propostos em concurso de 1916 para casarões da avenida Paulista, em que figuravam horta, galinheiro e pomar. O urbano e o rural ainda se encontravam muitas vezes, até nas mais sofisticadas residências.

A economia do café trazia para a cidade grande desenvolvimento socioeconômico, com conseqüentes alterações urbanas. A atração de um enorme contingente populacional para a produção cafeeira, que chegava pelo porto de Santos, trazia novos hábitos. Esse contingente de novos moradores constituía-se, sobretudo, de imigrantes europeus. A ele se somavam aqueles que, somente 30 anos antes, haviam sido libertados da escravatura e deixados à disposição do mercado de trabalho. Mesmo que fossem uma mão-de-obra desqualificada e sem poder de compra, tal grupo ajudava a compor a forte demanda habitacional.

A industrialização contribuía para o crescimento da cidade, atraindo um contingente cada vez maior de pessoas ávidas pelo bem-estar proporcionado pelo desenvolvimento.

O ritmo da construção decaía enormemente nas proximidades da Primeira Guerra Mundial, criando condições para a especulação de arrendamento. Sem outro recurso, as famílias procuravam os cortiços - construções feitas para locação, com unidades habitacionais mínimas, localizadas em áreas centrais, de uso coletivo, mas que contavam com energia, água potável, esgoto - ou repartiam a despesa do aluguel dividindo com outras famílias uma mesma casa. 


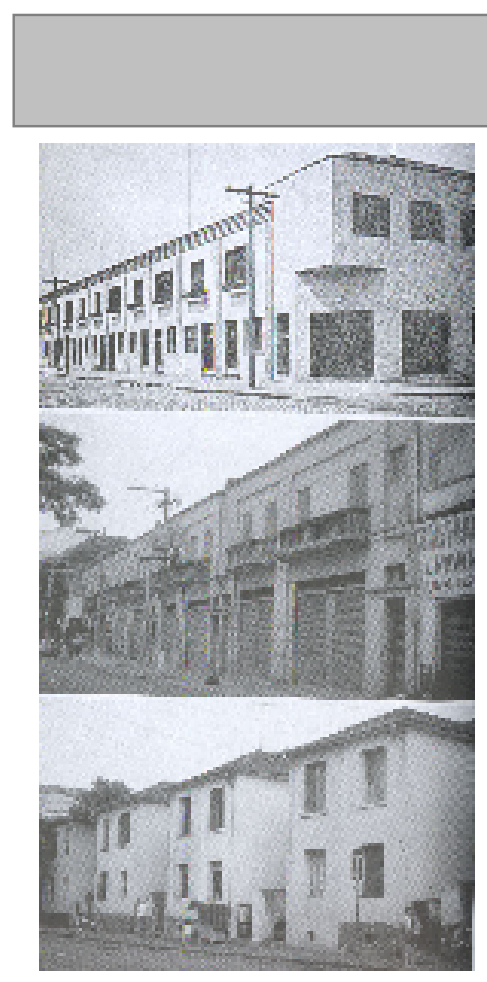

Fig. 28 - Casas populares de aluguel (BONDUKI, 1998).
A modernização da cidade na terceira década do século $X X$ começava a evidenciar seus profundos conflitos; "a guerra, o crescimento do proletariado, as primeiras greves operárias, a falta de habitação vêm marcar profundamente" a década de 1920 em São Paulo (SEGAWA, 2004, p. 128).

Com a quebra da bolsa em Nova York em 1929 e a Revolução de 1930 no Brasil, a oligarquia agroexportadora ia dividindo influência com tecnocratas, militares e empresários ligados à área industrial. Em 1939 a agricultura respondia por 57\% da economia brasileira, contra 43\% da atividade industrial.

Na Era Vargas (1930-1945), a economia migrava da agroexportação para o eixo urbanoindustrial, trazendo conseqüências modernizadoras para as cidades, que tiveram como características principais "o planejamento das cidades, a funcionalização dos espaços, a organização de uma hierarquia viária eficiente e a definição de políticas de construção mediante códigos edificatórios vinculados a padrões urbanos" (SEGAWA, 1998 p.35).

Do ponto de vista urbano, os aspectos teóricos do Modernismo iam de encontro aos novos rumos que tomava a sociedade brasileira, mais precisamente em São Paulo.

No entanto, em sua origem na Europa, o Movimento Moderno tivera grandes vínculos sociais, ligados a uma sociedade já organizada em que as classes sociais tinham seus papéis - e seus direitos. A questão da habitação operária era uma questão central da teoria modernista. 


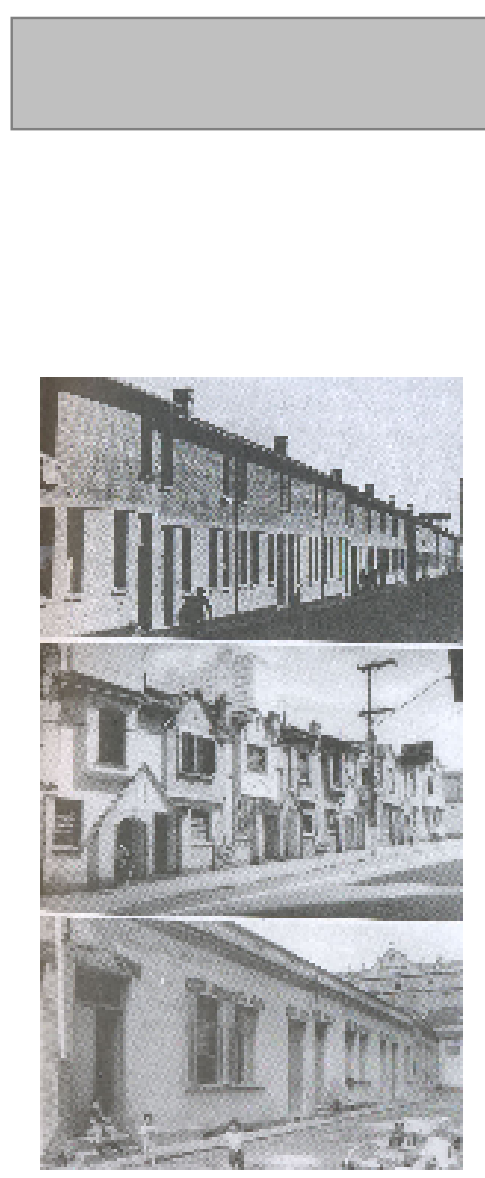

Fig. 29 - Casas populares de aluguel (BONDUKI, 1998).
No Brasil, as primeiras manifestações modernistas nas artes se deram na literatura e nas artes plásticas. Na arquitetura, Gregori Warchavchik era um dos pioneiros a introduzir as idéias que se desenvolviam na Europa nessa área.

A elite industrial criava condições para que "funcionalismo, utilitarismo, estandardização", que se apresentavam como "palavras de ordem numa formulação de modernidade engajada" (SEGAWA, 1998, p. 54), tivessem alguma repercussão entre os produtores de habitação

Tal ambiente, no entanto, não foi suficiente para que a produção na construção civil chegasse a um nível industrial, condição fundamental para o sucesso da empreitada moderna. No campo da habitação, o Estado - personagem fundamental para a implantação orquestrada na escala industrial - não foi capaz de reger tais mudanças.

No entanto houve experiências na implantação de conjuntos habitacionais durante o período Vargas - talvez as mais bem-sucedidas dentre as diversas tentativas - , encabeçadas pelos Institutos de Aposentadoria e Pensão, mostrando a "cooptação da linguagem moderna pelo Estado na década de 1930" (SEGAWA, 1998, p. 49).

Quanto à localização, os projetos de habitação da época poderiam ser entendidos segundo duas experiências: como a habitação coletiva "Siedlung", conjuntos habitacionais alemães distanciados do centro urbano, modernos em seus aspectos filosóficos e tecnológicos, e como o "Hof" vienense, próximo ao centro urbano, que no período entre guerras alcançou o número de 63.071 unidades 


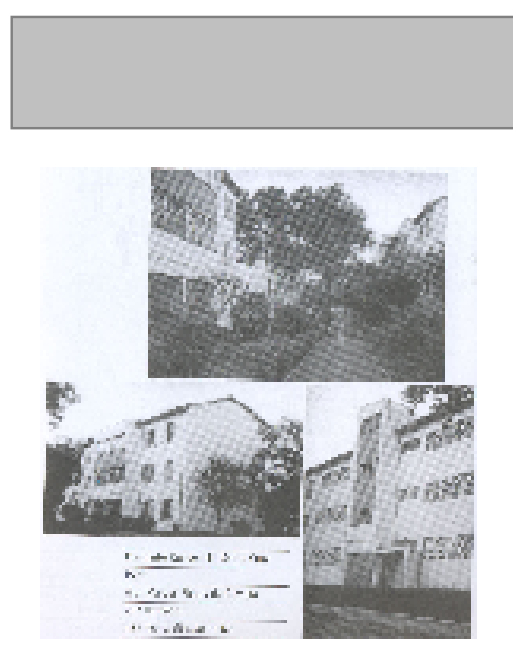

Fig. 30 - "IAPIs" - Santa Cruz (BONDUKI, 1998).

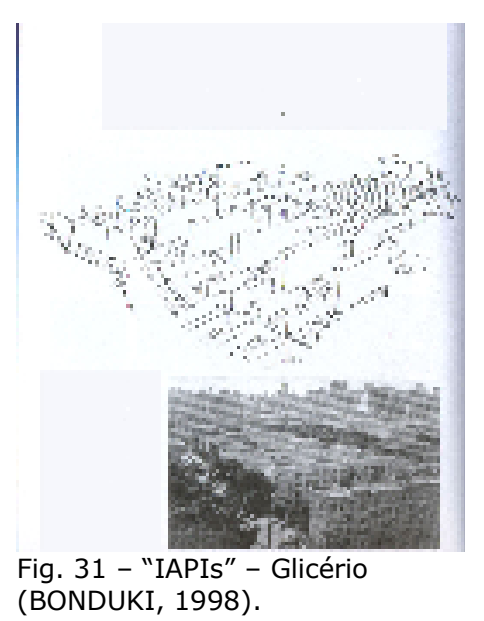

habitacionais construídas ${ }^{11}$. Como várias outras experiências desse tipo, uma das principais questões a serem enfrentadas era a produção das unidades habitacionais, em plena era da ascensão da cidade industrial.

A cidade industrial era o cenário onde se desenvolviam as idéias do urbanismo e arquitetura modernos. E, como instrumental de produção, o binômio fordismo-taylorismo servia de apoio teórico.

São três os elementos importantes para o bom funcionamento de um sistema produtivo "fordista", no qual a produção em massa, obtida pela multiplicação geométrica da produção industrial, era alcançada com recurso ao taylorismo, organização do trabalho assim caracterizada:

"produção em massa, com polarização crescente entre idealizadores qualificados e executantes sem qualificação, com mecanização crescente, que acarretava uma forte alta de produtividade [....] e alto volume de equipamento [...] utilizados pelo trabalhador; repartição regular do valor agregado, isto é, um crescimento do poder aquisitivo dos assalariados, paralelo ao crescimento de sua produtividade; a taxa de lucro das firmas permanece estável, com plena utilização das máquinas e com pleno emprego aos trabalhadores." (AMARAL, 2005, p. 64-65)

$\mathrm{Na}$ Europa, eram vários os exemplos de empreendimentos que usavam tais conceitos e resultaram na construção de milhares de unidades habitacionais.

${ }^{11}$ Sobre essas duas experiências, ver Perfil de necessidades e projeto de habitação: um estudo de métodos, tese de doutorado de P.J.A. Amaral (São Paulo: FAUUSP, 2005, p. 1-56). 


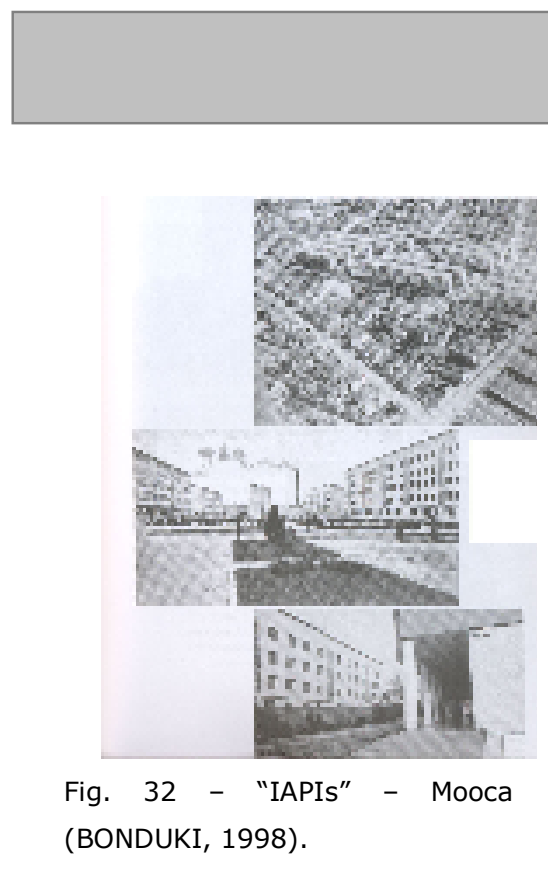

No Brasil a demanda por habitação crescia em proporções gigantescas. Em 1900 a cidade de São Paulo abrigava 240.000 habitantes. Em 1933 passava a abrigar um milhão.

Técnicos empenhavam-se em discutir os problemas e vislumbrar soluções no conjunto da sociedade. O primeiro Congresso de Habitação de São Paulo foi realizado em 1931.

"O objetivo do Primeiro Congresso foi procurar soluções para os problemas urbanos de São Paulo, destacando principalmente o problema da habitação para a população de baixa renda. Durante o congresso aconteceu uma exposição de material de construção, uma vez que foram inúmeros os trabalhos apresentados que tratavam de equacionar tecnicamente os diversos fatores necessários para construir habitações baratas, econômicas, dentro de uma concepção de espaço mínimo, e, ao mesmo tempo, respeitando o receituário prescrito pela técnica sanitária. Além do aspecto técnico, os participantes do congresso enfatizaram também o aspecto moral e higiênico da habitação econômica." (SAMPAIO, 2002, apud AMARAL, 2005, p. 70).

A partir de 1938, sob Getúlio Vargas, as preocupações quanto à provisão de moradias às classes operárias passou a fazer parte das agendas governamentais. Vários empresários ligados à organização industrial, a começar nos anos 1940, fundaram organizações como o Instituto de Organização Racional do Trabalho (IDORT) (AMARAL, 2005, p. 71).

Era grande o movimento para a produção de materiais de construção que reduzissem seu custo e incrementassem a produção de imóveis habitacionais (para venda ou locação).

As diversas tentativas de discutir os problemas habitacionais e os rumos da arquitetura brasileira frente ao crescimento industrial em São Paulo não conseguiam consolidar um conjunto 
teórico que embasasse alguma intervenção - ou a teoria não foi suficiente para que a realidade pudesse se alterada. Para tanto, seriam necessárias também condições concretas, como disponibilidade de recursos e uma economia dinâmica que garantisse produção e consumo.

Luiz Schreider (1838-1892), engenheiro e arquiteto da Real Academia de Belas-Artes de Berlim, que atuava no Rio de Janeiro, admitia: "é também indiscutível que a arquitetura ainda é pouco cultivada entre nós, achando-se a arte de construir ainda hoje mantida na camisa de força da 'chamada rotina, e tudo isso pelo fato de se entender que um arquiteto pode formar-se na Academia das Belas-Artes." (SEGAWA, 1998, p. 30).

Industrializar a construção era passo necessário para se implantarem políticas públicas de produção em massa de moradias.

Mesmo assim, sem atingir uma real industrialização da construção, de 1937 a 1964 foram produzidas no Brasil cerca de 143.000 unidades habitacionais pelos Institutos de Aposentadoria e Pensões (IAPs) e pela Fundação da Casa Popular (FCP) (BONDUKI, 1998, apud AMARAL, 2005, p. 74) 


\subsection{A arquitetura brasileira nas novas cidades}

O início do século XX trazia modernização à cidade de São Paulo. No entanto, em uma análise mais aprofundada dos rumos que tomava a arquitetura, verificava-se um grande descompasso,

fruto da posição desta não apenas como disciplina acadêmica, mas como prática nas cidades brasileiras de então.

A contratação de um arquiteto europeu em 1889 fora assim justificada pelo ministro Antonio Ferreira Vianna, do Império:

"A elevação do nosso nível intelectual torna cada dia menos suportável a falta de graça e estilo em nossas construções, ainda as destinadas a serviços públicos da maior importância, como se a beleza não fosse condição essencial ou dela se pudesse prescindir a troco da solidez, nem sempre conseguida [...]. $\dot{E}$ preciso que à primitiva arte de construir se juntem a concepção e a dignidade da arquitetura, cujos exemplares são tão raros entre nós, e, o que é mais inquietante, em geral vieram do período colonial." (VIANNA, 1890, apud SEGAWA, 1998. p.31)

Os ventos progressistas, porém, não eram estranhos ao âmbito da construção, como avaliava o engenheiro Bernardo Ribeiro de Freitas em 1888:

"O século 19 instigado pelas grandes conquistas das ciências e das indústrias, forte pelo ferro que tornou-se a sua matéria-prima por excelência, revoltou-se contra o passado e de ousadia em ousadia apresentou formas inteiramente novas que acharam sua razão de ser nas leis da estatística, mas que se afastaram da estética até agora conhecida. Estamos em pleno domínio da revolução.". (SEGAWA, 1998, p.31) 


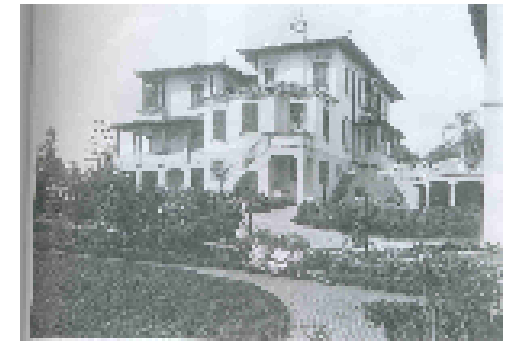

Fig. 33 Projeto neocolonial Ricardo Severo, 1918 (LEMOS, 1999).
O cenário não só estava pronto para a modernidade, mas, sobretudo se preparava para alcançá-la. Ricardo Severo (1869-1940), engenheiro civil formado na Academia Politécnica do Porto, em 1891, associado em 1909 ao escritório de Ramos de Azevedo, em São Paulo, discursa:

"Não procurem ver, meus senhores, nesta veneração tradicionalista, diluída em nostálgica poesia do passado, uma manifestação de 'saudosismo' romântico e retrógrado. Com efeito, para criar uma arte que seja nossa e do nosso tempo, cumprirá, qualquer que seja a orientação, que não se pesquisem motivos, origem, fontes de inspiração, para muito longe de nós próprios, do meio em que decorreu o nosso passado e no qual terá que prosseguir o nosso futuro. Ficará bem explícito que não se intima ao artista de hoje a postura inerte da esfinge, voltada em adoração estática para os mitos do passado, mas sim a atitude viva do caminhante que, olhando o futuro, tem de seguir um caminho demarcado pela experiência e pelo estudo do passado, e cuja única diretriz é o progresso e a glória das artes nacionais." (SEVERO, 1916, apud SEGAWA, 1998, p. 35).

Uma das principais características da arquitetura no período é analisada por Segawa:

"A busca de uma arte moderna no contexto brasileiro foi alimentada por um intenso debate da questão da nacionalidade e da autonomia nacional - do tosco ufanismo da virada do século, atravessando as instituições eugenísticas ${ }^{12}$ e redundando no patriotismo mistificado das comemorações do centenário da

${ }^{12}$ Eugenia, segundo definição de Francis Galton (1883), é a "ciência que lida com todas as influências que melhoram as qualidades natas de uma raça; também aquelas que as desenvolvem à máxima vantagem" (GALTON, F. Essays on eugenics. London: The Eugenics Education Society, 1909. p. 35). No Brasil, Segundo Rita Cristina Carvalho de Medeiros Couto: "A Eugenia se tornou um amálgama ideológico num espaço de conflito, contextualizado pelo fracionamento dos interesses econômicos entre setores agrários alijados do poder 
independência. A versão arquitetônica desses episódios da história brasileira das primeiras décadas do século consubstancia-se na mirabolante campanha neocolonialista, que, em sua essência, trazia algumas raízes da vertente de arquitetura moderna que vai irromper no Rio de Janeiro, na década de 1930, protagonizada por um ex-discípulo do neocolonial: o arquiteto Lúcio Costa (1902-1998)." (SEGAWA, 1998, p. 39)

Em meio às discussões e a mudanças nas práticas projetuais e construtivas, a cidade de São Paulo ia vivendo seu espantoso crescimento, durante o qual, sem saber-se bem como, novas moradias deveriam ser construídas em meio a uma realidade desconhecida - quer ou não estivessem o poder público e a iniciativa privada conscientes dessa necessidade - para as massas urbanas que aumentavam na cidade, com seus novos hábitos urbanos.

Para a arquitetura nacional poderia ter sido este um período bastante fértil de produção. Não foi, porém, o que ocorreu.

A aversão da elite intelectual ao pragmatismo impedia um verdadeiro desenvolvimento do pensamento arquitetônico autêntico, que poderia ter aí alcançado linguagem própria, se o período tivesse contado com coragem para voltar-se aos próprios problemas ao invés de procurar por heróis universais e importá-los para o terreno nacional. Macunaíma, o "herói sem nenhum caráter" de Mário de Andrade, espontaneamente criativo, permanecia personagem literário.

pela burguesia cafeeira e de recém-surgidos industriais, além de uma classe média multifacetada e de reivindicações operárias constantes" (COUTO, 1994. p. 18-19). 
A entrada do Movimento Moderno na arquitetura em São Paulo se dava pelas portas das artes, principalmente literárias, mas também das artes plásticas, no espírito da Semana de Arte Moderna de 1922. 


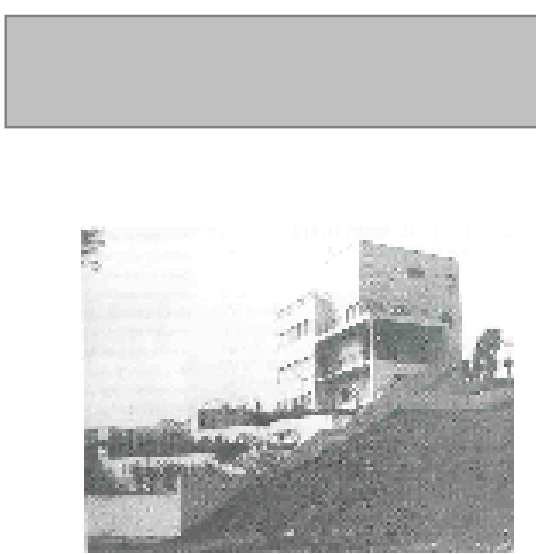

Fig. 34 - Casa da Rua Bahia Gregori Warchavchik, 1930 (SEGAWA, 1998).

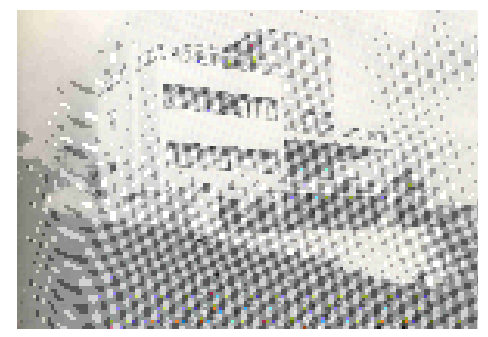

Fig. 35 - Casa da Rua Bahia Gregori Warchavchik, 1930 (SEGAWA, 1998).

\section{Nesse evento:}

"a arquitetura não acompanhava o mesmo vigor do debate literário ou pictórico: a mostra em particular dos arquitetos na Semana de Arte Moderna não registrou nenhuma celeuma. Apresentaram-se apenas desenhos; a ausência de obras construídas reforçou a indiferença do meio profissional. [...] Os arquitetos da Semana de Arte Moderna não ostentavam uma consistência programática como os seus colegas literatos ou artistas plásticos. [...] O debate na arquitetura estava virtualmente monopolizado pelo proselitismo e pelas obras executadas sob a inspiração de José Mariano Filho e Ricardo Severo na cruzada neocolonial - postura que sombreava a preocupação da nacionalidade dos modernistas e arremessava a questão do nacionalismo ao rol da discussão estilística, nos moldes acadêmicos." (SEGAWA, 1998, p. 43)

Aproximando-se mais da materialidade da arquitetura enquanto arte da construção, o arquiteto Rino Levi (1901-1965), que estudara na Real Escola Superior de Arquitetura, em Roma, enviava do exterior em 1925 um artigo ao jornal O Estado de São Paulo em que já expunha algumas idéias que floresceriam em seu futuro trabalho projetual no Brasil:

"[...] praticidade e economia, arquitetura de volumes, linhas simples, poucos elementos decorativos, mas sinceros e bem em destaque [...]. É preciso estudar o que se fez e o que se está fazendo no exterior e resolver os nossos casos sobre estética da cidade com alma brasileira. Pelo nosso clima, pela nossa natureza e costumes, as nossas cidades devem ter um caráter diferente das da Europa. Creio que a nossa florescente vegetação e todas as nossas inigualáveis belezas naturais podem e devem sugerir aos nossos artistas alguma coisa de original dando às nossas cidades uma graça de vivacidade e de cores, única no mundo." (LEVI 1987, apud SEGAWA, 1998, p. 44) 


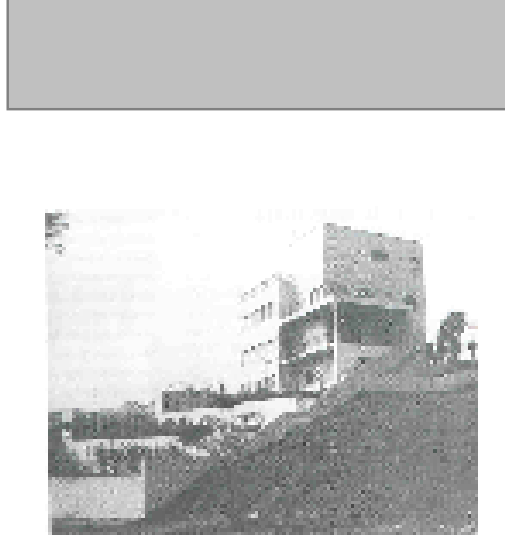

Fig. 36 - Casa da Rua Bahia Gregori Warchavchik, 1930 (SEGAWA, 1998).

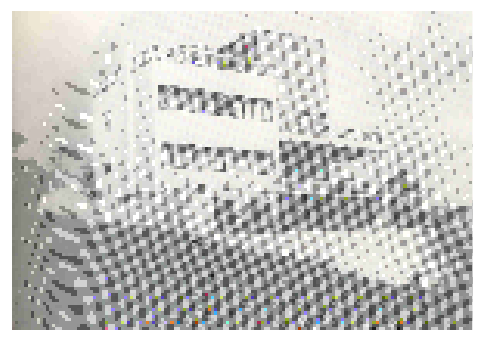

Fig. 37 - Casa da Rua Bahia Gregori Warchavchik, 1930 (SEGAWA, 1998).
Outro artigo do mesmo ano, de Gregori Warchavchik (1896-1972), publicado no Correio da Manhã, do Rio de Janeiro, assim descrevia a construção no futuro:

"Construir uma casa a mais cômoda e barata possível, eis o que deve preocupar o arquiteto construtor da nossa época de pequeno capitalismo onde a questão da economia predomina todas as demais. A beleza da fachada tem que resultar da racionalidade do plano da disposição interior, como a forma da máquina é determinada pelo mecanismo que é a sua alma." (FERRAZ, 1965, apud SEGAWA, 1998, p. 46)

Até 1945, São Paulo consolidava-se como pólo industrial e acelerava sua urbanização. A partir daí, a cidade iniciava um forte processo de verticalização, num período de fértil criação arquitetônica nacional, ainda que sem relação direta com o déficit habitacional dentro de alguma política pública. Os interesses imobiliários, sim, eram os grande promotores desse processo.

Levi e Warchavchik eram os pioneiros na introdução de novos conceitos arquitetônicos. Levi teve grande atuação na área de projeto de edifícios altos na região central da cidade. 


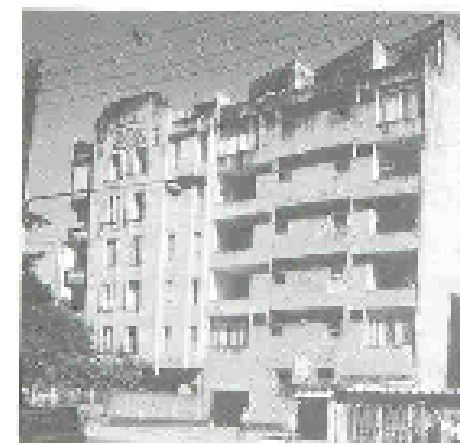

Fig. 38 - Edifício residencial, avenida Angélica, 172. As plantas dos apartamentos não repetem as soluções de agenciamento das plantas das casas tradicionalmente usadas na cidade (SEGAWA, 1998).
A instalação de indústrias multinacionais em São Paulo e nas cidades vizinhas, a partir dos anos 1950, criava um grande pólo de atração de correntes migratórias. A população da cidade em 1950 atingia 2198096 habitantes, em 1960 era de 3825351 e em 1970 chegava a $5978977^{13}$. A expansão da cidade alcançava grandes proporções.

"[...] a municipalidade optou por acomodar o contínuo crescimento populacional através da ocupação periférica da cidade e priorizar a utilização do automóvel e do ônibus, permitindo à população de baixa renda um maior deslocamento em relação ao centro. Como a população pobre não podia contar mais com a moradia de aluguel em áreas mais centrais - que até os anos 40 foi a principal solução para a habitação popular - a casa própria passou a ser o grande objetivo da população, consumindo os loteamentos periféricos e autoconstruindo sua moradia." (VILARIÑO, 2006, p. 35)

A classe média ocupava o centro, que se adensava com edifícios residenciais de grande altura. Grande parte desses edifícios se compunha de quitinetes e a Lei Municipal 5261/57 restabelecia cota mínima por apartamento (SOMEKH, 1987, apud VILARIÑO, 2006 pg. 35) Isso levava a que bairros vizinhos fossem sendo ocupados pela verticalização.

A mudança de hábitos e o acesso a bens de consumo pelas classes média e alta fazia com que a localização central histórica passasse a ser vista como obsoleta, sendo substituída em importância pelo "Novo Centro" nos anos 1950, com profundas conseqüências para a estruturação da cidade (VILLAÇA, 2001, p. 117).

13 Fonte: IBGE (2000). 
De 1945 a 1954, o crescimento incontrolado tomava conta de São Paulo, que se consolidava como importante centro socioeconômico brasileiro, sendo desse período o início do processo de incorporação imobiliária ${ }^{14}$.

Até 1964 a expansão rumo à periferia não foi acompanhada pela dotação dessas áreas com equipamentos e serviços públicos. A intensa migração nacional acelerava periferização, que até 1982 se intensificou, sendo acompanhada pela verticalização e modernização dos espaços urbanos já ocupados, dada a atuação do Banco Nacional da Habitação (BNH), com implantação de infraestrutura (água, esgoto, metrô), além de atualizações na legislação urbana e iniciativas de planejamento para uma parte da cidade, ampliando-se a intervenção do Estado no espaço urbano (SOUZA, 1994), ainda que de forma a preservar privilégios já adquiridos.

Segundo Vilariño (2006, p. 38), a Lei de Zoneamento implantada em 1972:

"[...] teve como objetivo proteger os bairros residenciais da elite e refrear o uso excessivo do solo em áreas centrais evitando o congestionamento [de veículos]. [...] As estratégias para alcançar tais objetivos foram: diminuir os coeficientes de aproveitamento dos terrenos, ampliar a oferta de infraestrutura viária e de transporte público baseado no ônibus para possibilitar novas frentes de expansão urbana e de loteamentos populares."

${ }^{14}$ Atividade exercida com o intuito de promover e realizar a construção, para alienação total ou parcial, de edificações ou conjunto de edificações compostas de unidades autônomas, regulamentado pela Lei 4.591, de 16 de dezembro de 1964 


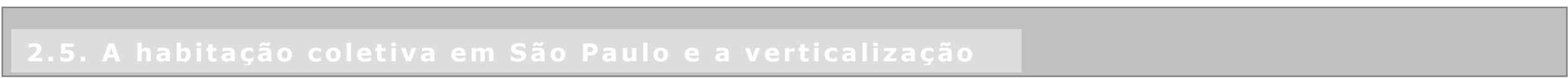

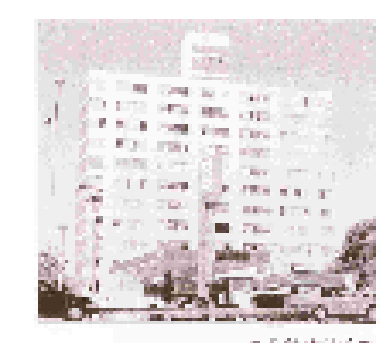
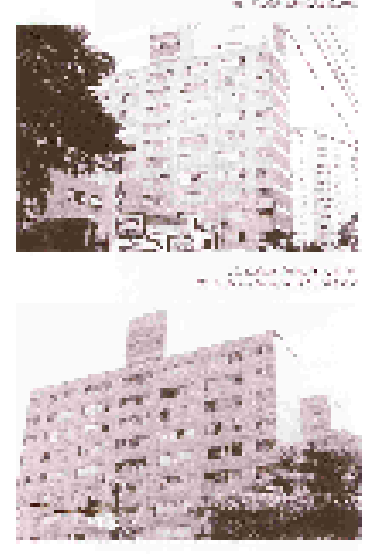

Fig. 39 - Edifícios de apartamentos Modular Gama, Modular Epson, Modulares Delta 1 e 2 (1970) - Abraão Sanovics (IMBROLITO, 2004).
O ambiente urbano que se desenhava na entrada dos anos 1920 em São Paulo demonstrava a complexidade dos problemas enfrentados.

"[...] a realidade [...] de exclusão: a das massas urbanas que lutavam para se adaptar à vida da metrópole, a novas formas, novas tecnologias, novos padrões de vida impostos, por pressão internacional. O ambiente refletia muito mais o caos do que efetivamente uma nova ordem urbana, fazendo a capital paulista expressar de qualquer forma um novo ritmo e estilo de desenvolvimento na entrada dos anos 20." (SOMEKH, 1997, p. 150)

O apartamento se apresentava como uma alternativa à moradia. "[...] a diminuição do poder aquisitivo, os aumentos de população e a saturação das zonas centrais fizeram surgir os dois caminhos a seguir: ou o indivíduo da classe média optava pelo pequeno chalet ou bungalow, ou o sobradinho geminado nos bairros afastados, longe do local de trabalho, ou aceitava o apartamento bem situado, aceitava o prédio de habitação coletiva" (LEMOS, 1978, p. 154).

A verticalização passava a ser a forma de aumentar a oferta de terreno urbano; o edifício de apartamentos, por sua vez, tornava-se a forma de aumentar a oferta de unidades habitacionais para uma classe média em expansão.

"A verticalização de São Paulo, que poderia se constituir numa solução para o barateamento das condições de moradia, no entanto, não era barata, fato que não é explicado nem pelas dimensões dos apartamentos nem pela localização exclusiva dos terrenos mais caros da cidade. É incorreta também a afirmação de que a verticalização ocorre em áreas já servidas pela infraestrutura." (SOMEKH, 1997, p. 160) 


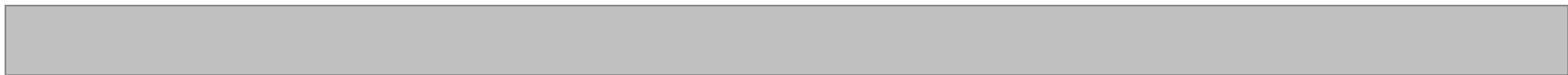

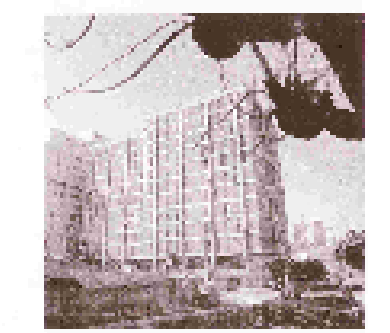
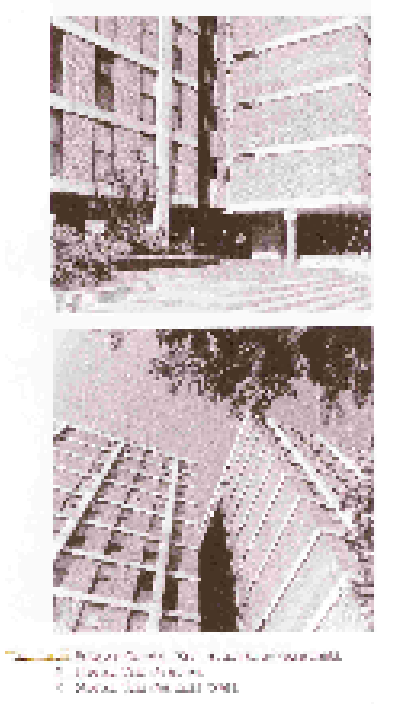

Fig. 40 - Edifício de apartamentos Gemini (1969) - Eduardo de Almeida (IMBROLITO, 2004).
O fenômeno tinha principalmente o propósito de aumentar a concentração, garantindo assim maiores lucros com a expansão urbana.

O edifício de apartamentos adaptava-se à vida familiar brasileira. O programa básico da casa brasileira não sofria drásticas alterações. A industrialização não chegava a mudar radicalmente os hábitos das classes médias.

"É que na Europa, desde os tempos antigos, o apartamento constituiu uma solução para as classes baixas, de pequeno valor aquisitivo, enquanto, no Brasil, ele surgiu de encomenda para uma classe situada na média dos escalões. Lá, o apartamento seguiu penosamente um caminho ascendente para servir às camadas superiores da sociedade. Aqui, a difusão do apartamento foi diferente - depois de muito tempo é que ele foi servir de moradia para o ex-favelado e que foi aceito como residência categorizada pelo rico! (LEMOS, 1978, p. 162)

Uma solução utilizada em várias partes do mundo voltada a enfrentar os problemas de moradia das classes mais baixas, diminuindo o custo da obra e maximizando o uso da infra-estrutura urbana, os edifícios de apartamentos em São Paulo eram construídos para especulação, como objetos de propaganda destinados à classes média. (O problema permanece, como veremos adiante.)

Identificar um modo de vida comum à maioria dos moradores de São Paulo, sem medições estatísticas, foi-se tornando cada vez mais impossível:

"A fisionomia e as características da cidade mostravam que São Paulo não era uma cidade nem de negros, nem de brancos e nem de mestiços; tampouco de estrangeiros ou de brasileiros, nem americana nem européia ou nativa, nem era industrial, apesar do volume crescente de fábricas, nem entreposto 


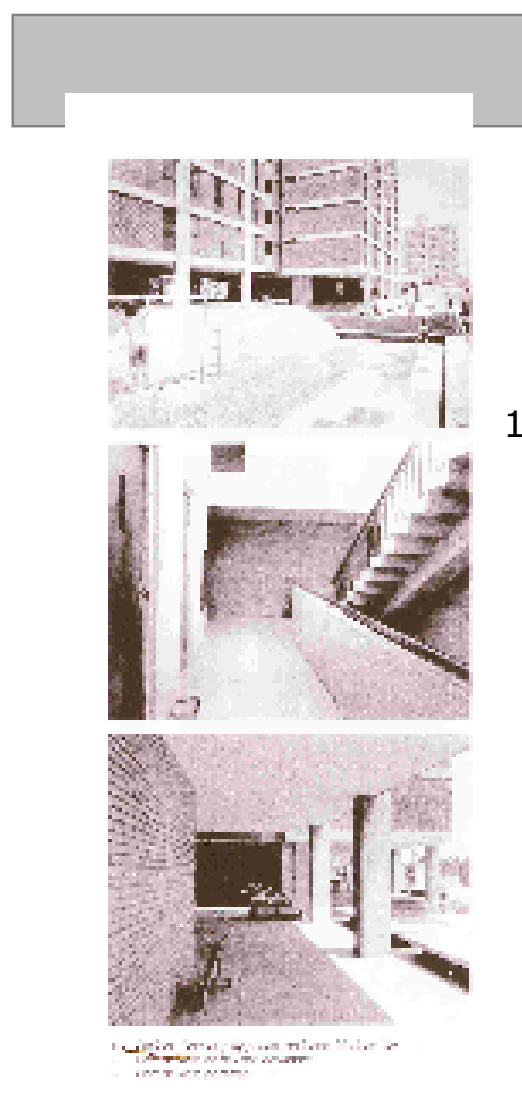

Fig. 41 - Edifício de apartamentos Gemini (1969) (IMBROLITO,

agrícola, apesar da importância crucial do café; não era tropical, nem subtropical, não era ainda moderna, mas já não tinha mais passado." (SEVCENKO, 1993, apud SOMEKH, 1997)

Nesse cenário social, a construção civil, base instrumental para o atendimento habitacional, passava pelas seguintes etapas, segundo Souza (1994):

1. 1850-1930 - Expansão cafeeira e construção civil. Nessa época, passa-se de uma grande dependência da técnica estrangeira, do trabalho escravo, dos mestres-de-obras e dos oficiaisartesãos para o domínio do cálculo do concreto armado. As décadas iniciais do século XX testemunham um grande surto de construções, do qual advêm as primeiras firmas especializadas no setor de construção civil.

1930-1955 - Industrialização substitutiva e construção civil. Em 1926 tem início a produção de cimento no país. O mesmo impulso seria dado à produção de materiais de construção em geral, com a fase de substituição de importações no período da Segunda Guerra Mundial. O primeiro grande boom imobiliário em São Paulo ocorreria com o fim da Segunda Guerra Mundial. Antes disso, nas décadas de 1930 e 1940, as empresas atuantes no setor de construção civil passam a agenciar seus próprios empreendimentos, e nesse período o Estado passa a assumir importante papel como responsável pela infraestrutura e também no subsetor de edificações, mediante legislação urbana e criação de caixas econômicas e fundos de financiamento.

2. 1956-1964 - Nova industrialização substitutiva e construção civil. Apesar de controlada por empresas estrangeiras, a industrialização passa por nova etapa de expansão e diversificação. A construção civil também conheceria um período de crescimento e modernização tecnológica.

Fig. 42 - Cidade Tiradentes (PMSP, 1999) 
3. 1964-1976 - Expansão recente e construção civil. A partir da década de 1960, o Estado assume definitivamente a tutela da construção civil no Brasil em quase todos os subsetores, desde a construção pesada para o provimento da infraestrutura necessária à reprodução do capital, numa época de forte crescimento econômico, até o amparo a edificações, que recebeu grande impulso com o Plano Nacional de Habitação (PNH), dinamizado somente a partir da instituição do Fundo de Garantia por Tempo de Serviço (FGTS) e do Sistema Brasileiro de Poupança e Empréstimo (SBPE).

4. A partir de 1976 - Crise e construção civil.

Um parêntese: tendo-se em vista que o foco desta pesquisa são as habitações das massas, cabe salientar que o termo habitação de interesse social é inapropriado para a avaliação de questões da arquitetura habitacional coletiva.

Em São Paulo, o termo interesse social (ou interesse proletário, ou operário), aplicado a projetos arquitetônicos, tem hoje tão grande conotação discriminativa, e até mesmo segregatória, que empregá-lo limitaria a leitura da pesquisa e o alcance que se pretende.

O encadeamento das idéias até aqui expostas revela que a lógica de localização e construção da habitação "de interesse social" em São Paulo atendeu a interesses das classes dominantes, petrificando-se reiteradamente na legislação e na forma de ocupação. Ater-se a seu significado corrente traria o risco de se considerar tal fato, erroneamente, como elemento imutável de realidade. O modus operandi que ainda hoje determina as propostas de políticas públicas de habitação no país as leva a conservar traços desse passado, fazendo a habitação popular ser encarada como historicamente o foi. Sendo esse modus operandi criação histórica, e não inerente 


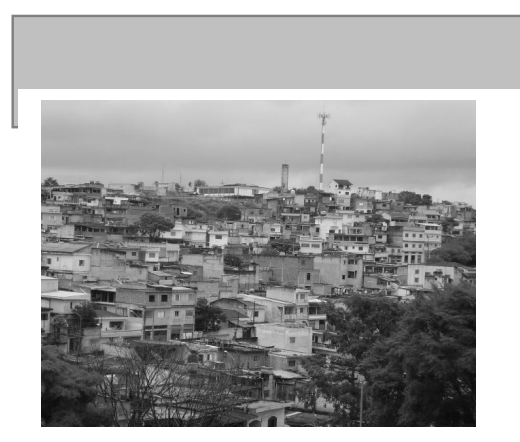

Fig. 45 - Autoconstrução (CDHU, 2006).

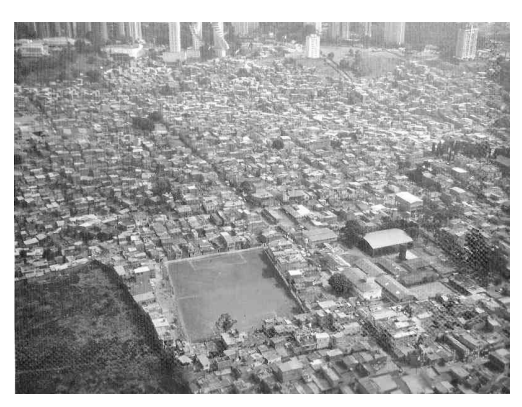

Fig. 46 - Favela Paraisópolis (MEYER, 2004). aos processos de urbanização, pode, assim como foi montado, também ser desmontado. Colaborar com elementos que levem a concretizar essa possibilidade é um dos objetivos deste trabalho.

O Movimento Moderno nas cidades industriais européias tinha o mérito de propor construir a cidade para todas as classes sociais, vendo-as como necessárias não apenas para o funcionamento do sistema capitalista de acumulação, mas também para o funcionamento da cidade industrial, ela própria instrumento de acumulação.

A arquitetura moderna referendada pela vanguarda européia tinha maior eco nos meios intelectuais do que nos propriamente arquitetônicos, sendo Le Corbusier uma de suas principais referências. Os arquitetos Rino Levi e Gregori Warchavchik, ambos com estadia em Roma, trouxeram em 1925 suas experiências com as principais idéias da arquitetura ligada à estandardização, à produção em série e outros aspectos relativos à escala industrial.

Os princípios ideológicos do Movimento Moderno e sua faceta social, no entanto, não tiveram em São Paulo repercussão nem imediata nem geral. Em 1932, Carlos da Silva Prado, engenheiroarquiteto formado pela Escola Politécnica de São Paulo, defendia o aspecto econômico da construção, e não apenas a modernidade construtiva e plástica, vendo a repetição, a padronização e a produção em série como elementos que privilegiavam o coletivo. 


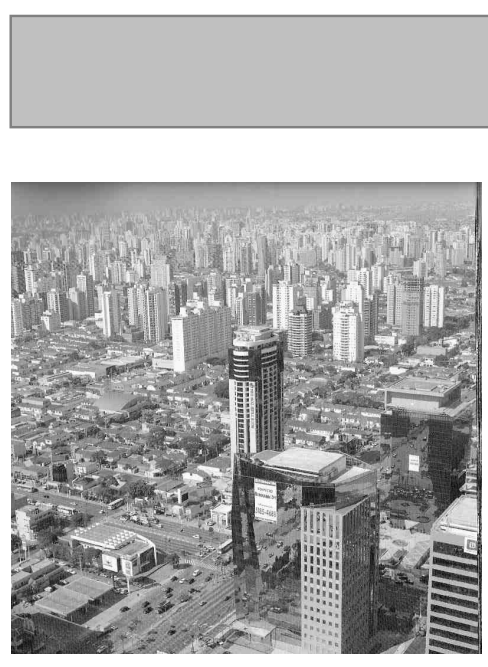

Fig. 47 - Região da avenida Berrini - processo atual de verticalização e expansão de serviços (MEYER, 2004).

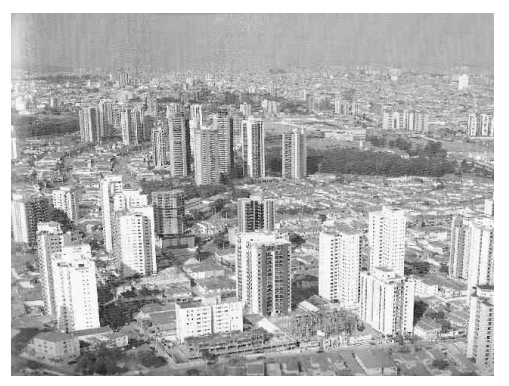

Fig. 48 - Anália Franco - processo atual de verticalização (MEYER 2004)
Suas idéias, porém, não tiveram grande eco, ficando para o ucraniano Gregori Warchavchik, de acordo com a historiografia da arquitetura, o lugar de iniciador da arquitetura moderna no Brasil, por sua ligação com a formação européia e os principais expoentes da época: Ernst May, Le Corbusier e a Bauhaus. "Warchavchik inseriu o Brasil no mapa da arquitetura moderna mundial logo no início dos anos 1930. Nesse contexto, Warchavchik foi posicionado pela historiografia da arquitetura como o iniciador da arquitetura moderna no Brasil." (SEGAWA, 1998)

Uma das intenções deste trabalho é procurar ampliar a atuação dos arquitetos e urbanistas nas cidades como organizadores dos fluxos internos, e, portanto, de fundamental importância social, em funções agora já consolidadas e reconhecidas. Por essa razão o termo habitação de interesse social foi evitado, já que o principal significado que carrega é o de "projetar para os pobres" e não para as massas urbanas, e fazendo-o com uma arquitetura pobre, não-racionalizada, não-econômica, ineficiente e ineficaz, criando uma cidade pobre e não essencial. Tal realidade inexiste per se; foi construída e se constrói até hoje por todos os envolvidos, inclusive os que se ausentam.

As idéias modernistas iam de encontro a problemas sociais a serem resolvidos, tomando por isso a forma de discurso ideológico. A modernidade de Warchavchik refletia uma das facetas que se desenvolviam na Europa.

No entanto, Levi foi um dos mais atuantes arquitetos a partir dos anos 1940, tendo projetado e construído diversos edifícios de apartamentos, de quatro a dez andares, em média. Aos de até quatro andares não era exigido o uso de elevador. 


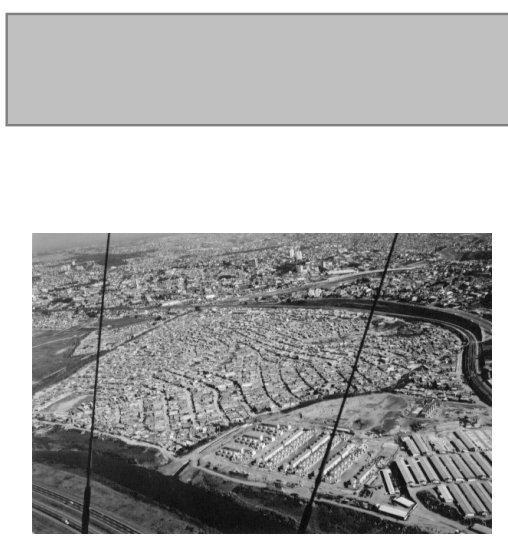

Fig. 49 - Favela Pantanal Intervenção do Estado para recuperação (CDHU, 2001)
"A intensa verticalização da área central de São Paulo foi acompanhada por uma ampla expansão horizontal. Enquanto a atenção dos arquitetos e urbanistas se concentrava no adensamento e verticalização das áreas centrais, por representarem o desenvolvimento econômico da nova metrópole, a expansão periférica da cidade se efetivava com ações de atores diversos: imóveis construídos por pequenos e médios investidores, autoconstrução descontrolada por parte das camadas mais pobres e conjuntos habitacionais realizados pelo Estado, institutos de previdência, grandes imobiliárias e construtoras."(GUERRA, 2001)

A exclusão das periferias nas preocupações dos arquitetos mais progressistas dessa época é algo que impressiona, visto que o Modernismo visava a construção em série para a massa urbana, tendo a industrialização como instrumental para tal empreendimento, e sua estética não estava dissociada de sua função social. A periferia era o local de alojamento das populações não atendidas.

Essa é uma das constatações mais decepcionantes a que se chega nesta pesquisa.

A arquitetura brasileira, autoproclamada como democrática, revolucionária e criativa, é excludente na base, e justifica essa forma de agir em enfoques subjetivos da realidade apresentados como fatos inexoráveis, como se tal realidade não houvesse sido construída.

Balanços e estruturas tensionadas por si só não têm alcance social nenhum, não têm nenhum significado democrático e não organizam o espaço urbano, um dos maiores objetivos da arquitetura e do urbanismo.

Esses arquitetos perderam a oportunidade de desenvolver, além dos projetos habitacionais, meios para a industrialização da construção através de seus trabalhos - salvo raras exceções como 
o arquiteto carioca Lelé (João da Gama Filgueiras Lima, nascido em 1932). Perderam também a oportunidade de iniciar, eles mesmos, um instrumental que pudesse intervir no modus operandi do crescimento urbano em São Paulo.

Frente à realidade que se coloca, porém, temos de tomar a lição desses mestres do passado e reelaborá-las, desenvolvendo metodologias mais apropriadas ao momento atual.

Uma das principais diferenças entre a arquitetura habitada pelas classes médias e altas e aquela habitada pelas classes proletárias está na forma como se organizam as populações. A habitação das primeiras é vista como uma mercadoria que se compra, principalmente depois da Lei do Inquilinato, de 1942. A solução do problema habitacional, na visão mais corrente, passa pela aquisição da mercadoria casa, e não pela obtenção do direito à moradia - focos bastante distintos.

A solução dos problemas de moradia não pressupõe uma casa própria para todos, mas uma forma de acesso digno a uma moradia digna e, no caso de São Paulo, com acesso às comunidades urbanas para todos, de fato, e não pela metade.

Até 1942, a construção de moradias para aluguel, fossem elas para as classes médias e altas ou proletárias, era uma prática comum e uma das soluções de que a população dispunha para a solução de seus problemas de moradia.

A Lei do Inquilinato, de 1942, criada sob o regime do Estado Novo, congelava o valor dos aluguéis, coibindo por um lado a prática especulativa, mas tornando ainda menos interessante o investimento em construção de novas moradias populares, contribuindo para aumentar ainda mais a crise habitacional que já estava instalada (BONDUKI, 1998). 
A partir da entrada em vigor dessa lei, a lógica se alterava drasticamente. A habitação era antes, em sua maior parte, cedida temporariamente mediante pagamento (aluguel). Para morar não era necessário ser proprietário. Podia-se viver uma vida toda de forma confortável e segura em moradias alugadas. Com o incentivo à aquisição da casa própria, mesmo o Estado passa a abrir mão do aluguel (locação) para o enfrentamento da questão habitacional.

A verticalização poderia ter sido uma forma de produção de habitações de aluguel, que contribuiriam para o enfrentamento do déficit habitacional, possibilidade que foi abortada pela Lei do Inquilinato.

A partir dos anos 1930, São Paulo passou por uma intensa verticalização, que diferentemente de várias outras cidades no mundo, atendia a demanda habitacional das classes médias. Edifícios eram construídos por uma família para que as unidades habitacionais fossem alugadas. A vida privada passava a ser vivida coletivamente. Os espaços semipúblicos e semiprivados não eram conhecidos das classes médias, que associavam essa forma de moradia coletiva aos cortiços.

Lemos (1978) assim classifica as moradias do período em:

1. cortiços (latrinas compartilhadas);

2. casas operárias (três cômodos + WC exclusivo);

3. casas da baixa classe média (quatro cômodos + instalação sanitária);

4. casas de classe média propriamente dita (sala de jantar, sala de receber, cozinha, WC, quartos);

5. casas de classe média alta (sala de jantar, sala de receber, escritório, copa, cozinha, quarto de empregada), implantadas no alinhamento, com jardins laterais; 
6. palacetes assobradados (morar à francesa), em que para cada atividade havia um cômodo (salas de senhoras, de fumar, sala de música, sala de bilhar, sala de almoço, um quarto para cada membro da família, quarto de hóspedes, quarto da governanta, cocheira e garagem);

7. soluções mistas (habitação + comércio),

Na segunda metade da década de 1920, Júlio de Abreu Junior (nascido em 1895) construía um edifício de seis pavimentos na Avenida Angélica, um dos primeiros edifícios modernos de apartamentos destinados à moradia: o Palacete Riachuelo, projetado em 1925, terminado em 1928 e inaugurado em 1932, sugerindo nova forma de morar. .

A área, como vimos, se situava na expansão oeste da cidade, com características urbanas mais modernas. O prédio se inseria em um lote urbano e não em gleba, não havendo mudança significativa da malha urbana, alinhado à calçada. A fachada principal era destituída de qualquer decoração, configurada apenas pelos vãos dos terraços das salas, as paredes dos banheiros e algumas aberturas para iluminação e ventilação, enquanto os quartos voltavam-se para a fachada posterior, para o sol poente. A cobertura abrigava as dependências dos empregados, pois não contava com elevadores. Começavam a se apresentar alguns itens inéditos na arquitetura até então.

$\mathrm{Na}$ cidade colonial, a moradia se inseria em um contexto que distinguia nitidamente o espaço de caráter privado - a própria residência - e o de caráter público - a rua. $O$ alinhamento na testada do lote era o diafragma inconfundível entre o público e o privado.

No edifício da avenida Angélica, o espaço semiprivado era uma novidade introduzida com a verticalização da habitação. A rua, a entrada do edifício, as escadas, o hall de distribuição de cada 
andar e o apartamento constituíam-se em uma seqüência progressiva que conduzia do espaço completamente público - a rua - ao espaço completamente privado - o apartamento. Começava a surgir, portanto uma transição entre o espaço coletivo e o espaço individual.

Em 1928, o Decreto Federal 5.481 dispunha sobre a alienação parcial dos edifícios com mais de cinco andares, com normas que regulamentavam a co-propriedade por apartamentos (condomínios). A construção de edifícios de apartamentos iria se disseminar nos anos 1940, com a Lei do Inquilinato. Paradoxal que pareça, a Lei do Inquilinato, por um lado, desestimulou a construção de habitações populares mas incentivou a construção de apartamentos, mostrando como a questão habitacional passou a ter um caráter mercadológico a medida que os apartamentos eram produzidos para a venda como mercadoria e não como provisão habitacional.

O edifício de apartamentos passava a ser uma mercadoria à venda, cuja construção deveria idealmente ser seriada, como na indústria de bens de consumo, idéia subjacente à "máquina de morar", de Le Corbusier.

Por outro lado o processo de produção na construção civil passava por mudanças, aproximando-se do taylorismo como processo administrativo e produtivo na área industrial de produção de bens de consumo. Vários autores estabelecem uma ligação estreita entre taylorismo e verticalização. A verticalização da cidade intensificaria a segmentação do espaço urbano.

"Na medida em que as indústrias se deslocam para a periferia, também a população proletária é obrigada a seguir o seu movimento, pelo mesmo motivo do deslocamento das empresas: valorização da terra. As residências térreas e de um andar são demolidas, construindo-se prédios de apartamentos, 


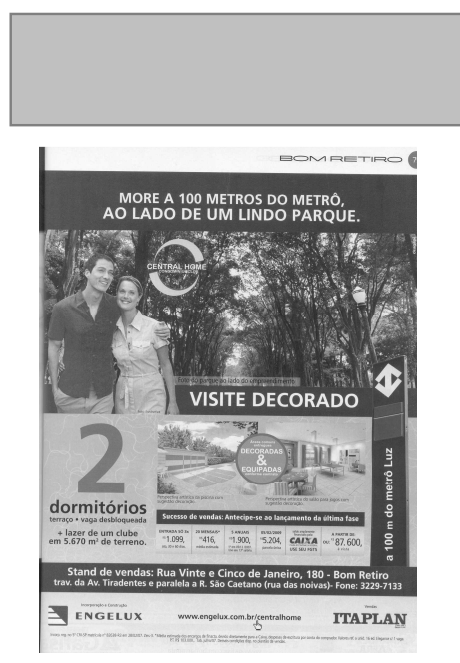

Fig. 50 - Lançamento de apartamentos na Luz, com referência ao metrô. (Informe publicitário)

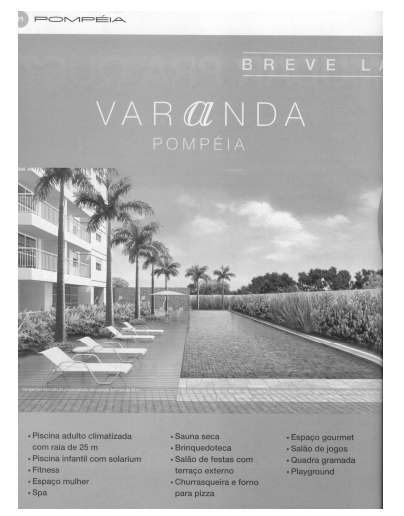

FIG.51 Lançamento na Pompéia, com destaque para os espaços de lazer (Informe publicitário, 2008) ocupados pela classe média. Também o comércio, que não se pode afastar demasiadamente do centro vai ocupar estas áreas, o mesmo fazendo determinados serviços: clínicas médicas e dentárias, escritórios comerciais, de engenharia, etc." (SINGER, 1968)

Esse movimento encarecia a vida no centro valorizado, levando a uma especulação imobiliária que se consolidaria no período, acompanhada de uma grande demanda habitacional que só tenderia a aumentar.

São Paulo é hoje dividida em cinco regiões (Centro, Norte, Sul, Leste e Oeste), que abrangem um total de 46 distritos ${ }^{15}$ em que vivem mais de 11 milhões de habitantes.

Ao longo do tempo as paisagens de cada uma dessas regiões e seus distritos se consolidaram, configurando um cenário em que nenhuma intervenção teórica é cabível se não precedida de conhecimento do real.

A diversidade das zonas na cidade em seus aspectos sociais, culturais e econômicos é de tal ordem que novas metodologias devem ser desenvolvidas para o enfrentamento de seus problemas.

Historicamente, o poder público acabou intervindo mais por omissão que por propósitos claros na construção do espaço urbano. As iniciativas privadas, muitas vezes, exerceram funções que caberiam ao Estado, que se manteve omisso.

\footnotetext{
${ }^{15}$ Fonte: Prefeitura do Município de São Paulo. Disponível em

<http://sempla.prefeitura.sp.gov.br/infocidade/htmls/3_regioes,_subprefeituras_e_distritos_muni_2008_69.html >.Acesso em: out. 2008.
} 
A partir de 2005, um forte boom imobiliário alterou bastante o quadro vigente. Em publicações recentes da revista Minha casa, meu imóvel (Verde Brasil Editorial), por exemplo, cada uma das regiões da cidade é caracterizada na seção "Meu bairro" de modo a valorizar as áreas em que a iniciativa privada promove seus empreendimentos.

Outras medidas desenvolvidas pela iniciativa privada para atrair compradores, em momento de forte oferta de habitações para as classes médias até as médias baixas, é a proposta de empreendimentos diversificados, em que se chega a fazer melhorarias no entorno para compensar a omissão do poder público, como no caso de empreendimentos na região metropolitana, em Alphaville e São Bernardo do Campo, que propuseram empreendimentos multifuncionais (OESP, 2007).

Bairros deteriorados se recuperam, como a Barra Funda, com a previsão de lançamentos de grandes proporções. Em alguns casos, a legislação de uso e ocupação do solo determina a forma desses empreendimentos. Nesse caso na Barra Funda, o terreno de interesse da construtora, de $63.000 \mathrm{~m}^{2}$, localizava-se em Zona de Interesse Social. "Para encaixar o projeto nas exigências da Prefeitura, serão criados entre 10 e 12 subcondomínios com no máximo 300 unidades, sendo 40\% de habitações de interesse social, de dois dormitórios, com $45 \mathrm{~m}^{2}$; $40 \%$ de habitação de mercado popular, três dormitórios com até $70 \mathrm{~m}^{2}$; e outros 20\% de uso livre, que terão $100 \mathrm{~m}^{2}$ e quatro dormitórios. Nosso objetivo é criar um novo bairro", declara o proprietário da construtora (OESP, 2008). No total, o empreendimento construirá 27 torres, oferecendo 2174 unidades habitacionais. 


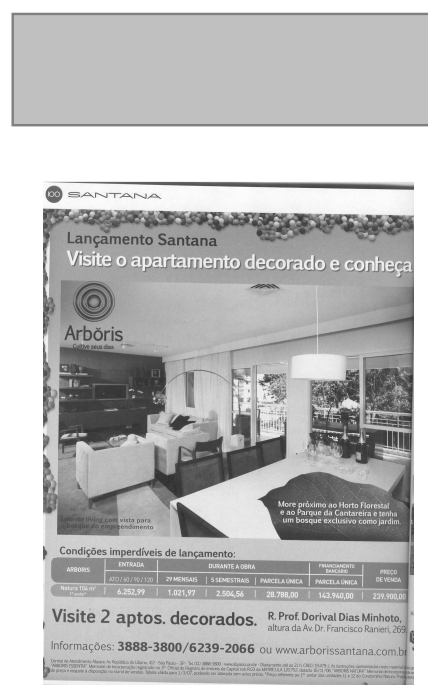

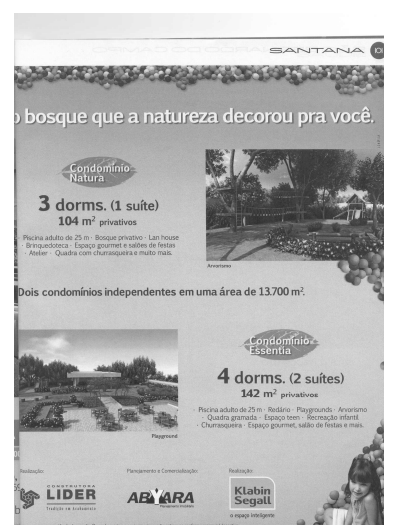

Fig. 52 - Lançamento em

Santana, com destaque para os espaços de lazer. (Informe publicitário)
A construção desses megaempreendimentos implica a destruição de boa parte da cidade. Não há critérios urbanísticos para essas intervenções, mas apenas cálculos numéricos de reservas de áreas potencialmente edificáveis, por regiões e distritos. O déficit habitacional de cerca de $400 \mathrm{mil}$ habitações na cidade de São Paulo faz o poder público ver com bons olhos esses números. Ainda assim, não se constata nenhuma coordenação ou ao menos incentivo para a elaboração de projetos inovadores para a habitação. As construtoras, que sob forte pressão da concorrência que aumenta, se vêem obrigadas a modernizar sua produção, racionalizar canteiros e investir em projetos, acabam por adiantar-se, na ausência de qualquer consideração do Estado quanto às conseqüências urbanísticas dessa atuação.

A falta de tradição de projetos de desenho urbano no Brasil agrava esse quadro. Estão presentes todos os ingredientes para uma ótima receita - grande demanda, crédito facilitado, injeção de recursos financeiros para ampliação de infraestrutura através do Programação de Aceleração do Crescimento do Governo Federal, entrada de capital estrangeiro via Bolsa de Valores no mercado imobiliário, maior estabilidade econômica - , mas permanece a pergunta: por que o Poder Público se retira do cenário urbano, participando dele, como sempre o fez historicamente, apenas através da construção de marcos urbanos e infraestrutura, sem intervir diretamente no desenho dos espaços intraurbanos?

Sob esse ponto de vista, as periferias oferecem um grande potencial para o desenvolvimento de projetos de desenho urbano, que necessitam ser conduzidos sob gestão do Estado, uma vez que, 
por um lado, historicamente a tarefa não interessa à especulação imobiliária e, por outro, de acordo com o Estatuto da Cidade, diz respeito às diretrizes gerais expressas em seu art. 2.0:

"XIV - regularização fundiária e urbanização de áreas ocupadas por população de baixa renda mediante

o estabelecimento de normas especiais de urbanização, uso e ocupação do solo e edificação, consideradas a situação socioeconômica da população e as normas ambientais;

$X V$ - simplificação da legislação de parcelamento, uso e ocupação do solo e das normas edilícias, com vistas a permitir a redução dos custos e o aumento da oferta dos lotes e unidades habitacionais;

$X V I$ - isonomia de condições para os agentes públicos e privados na promoção de empreendimentos $e$ atividades relativos ao processo de urbanização, atendido o interesse social.

Além disso, a população da periferia passou a ter maior peso político nas escolhas dos administradores públicos através de eleições. Outro fator de pressão junto às autoridades públicas é que a ocupação urbana da periferia geralmente está implantada em áreas frágeis do ponto de vista ambiental, sendo objeto de controle do Ministério Público.

A metodologia a ser adotada nas intervenções - não apenas de urbanização de favelas, mas também na de recuperação de áreas degradadas, com forte foco nas questões habitacionais - deve ser reavaliada e aprofundada, procurando-se aumentar a qualidade do espaço construído, uma vez que o caráter social faz parte das intervenções no âmbito da cidade e da moradia, por definição. 


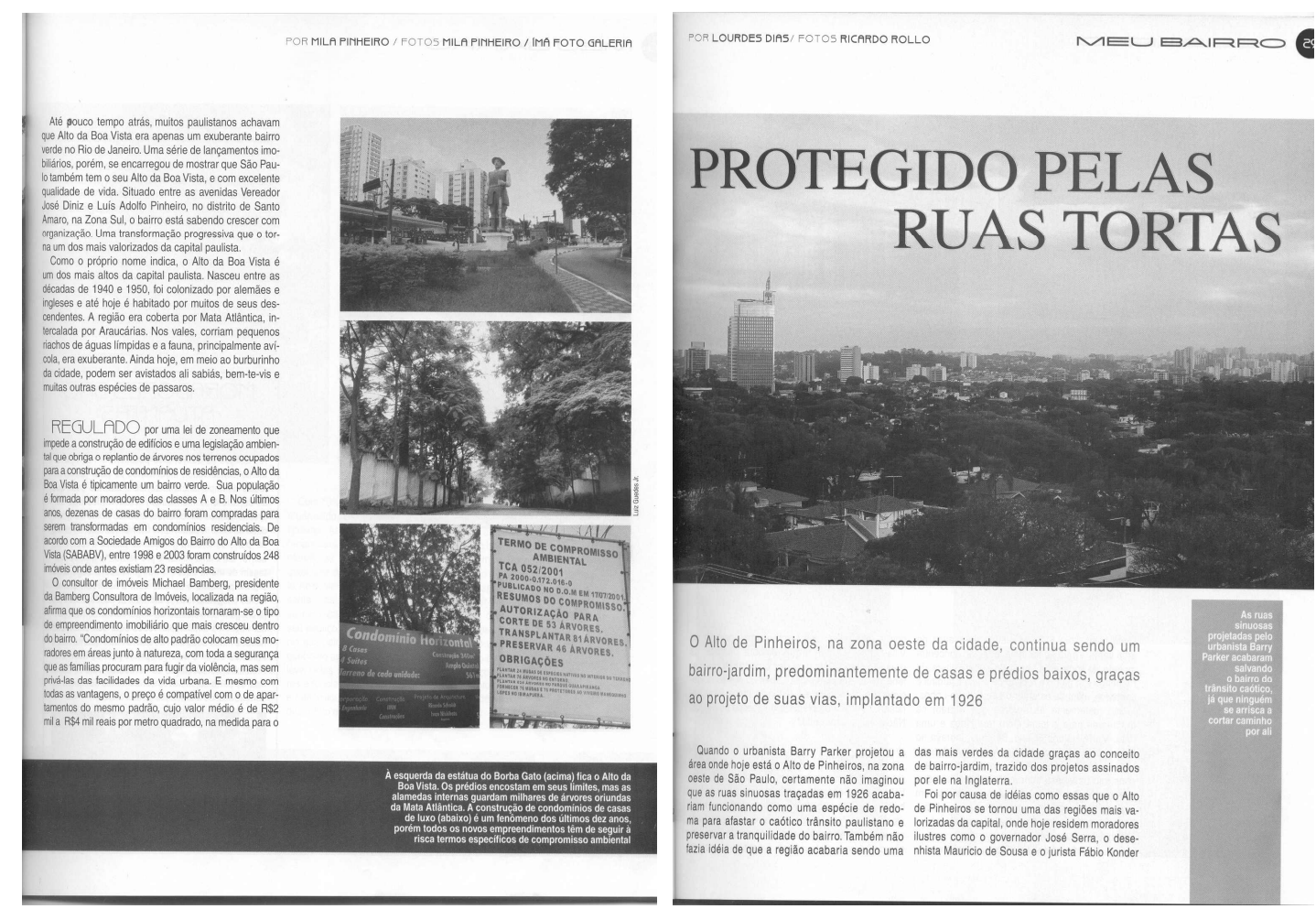

Fig. 53 - Alto da Boa Vista e Alto de Pinheiros - matérias da seção "Meu bairro", da revista Minha casa, meu imóvel (2007/2008). 

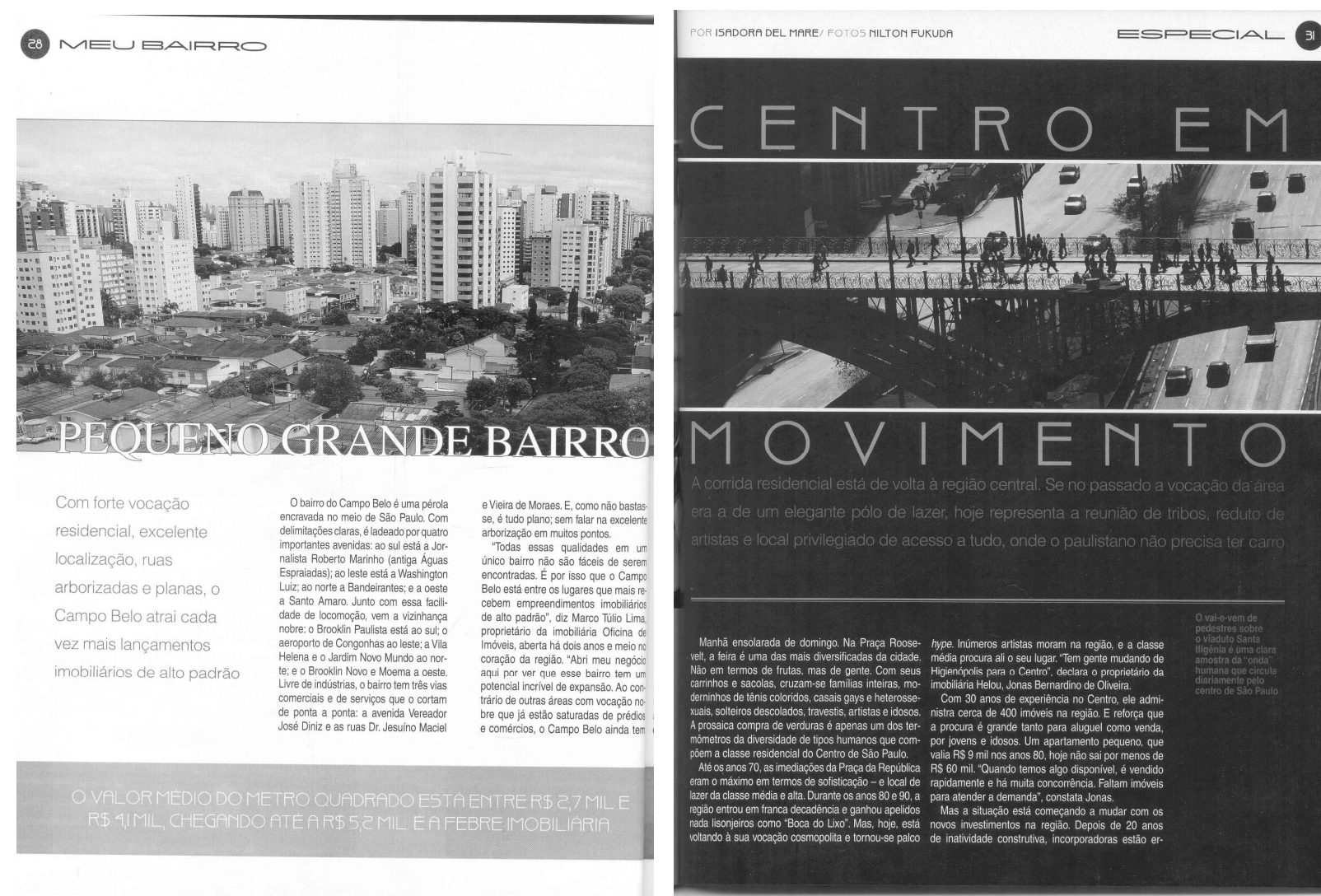

Fig. 54 - Campo Belo e Centro - matérias da seção "Meu bairro", da revista Minha casa, meu imóvel (2007/2008). 
(12) MEบロAIRRO

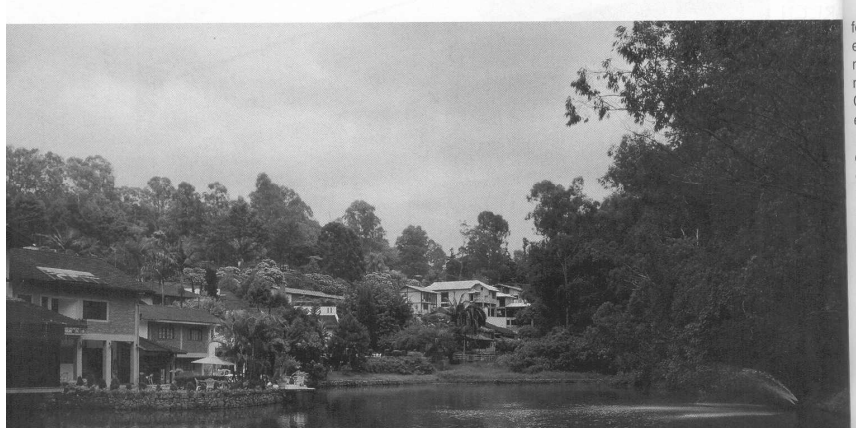

REFÚGIO PAULISTA

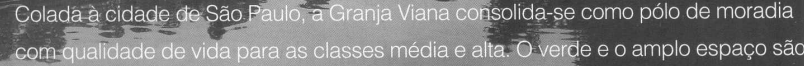
os chamarizes para que cada vez mais paulistanos busquemali seu oásis

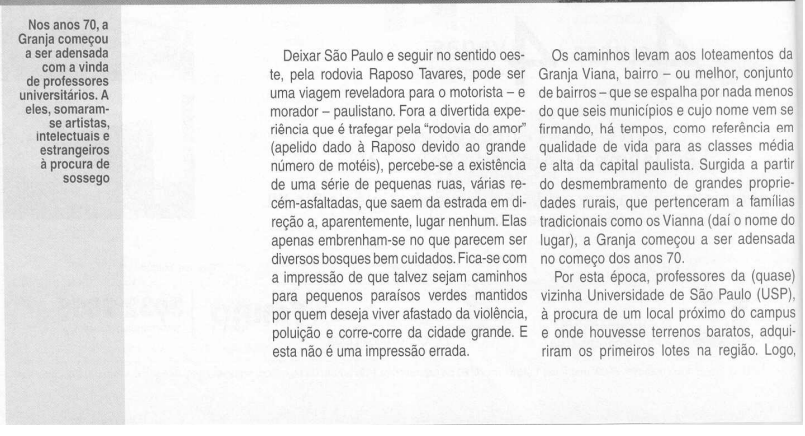

Fig. 55 - Granja Viana e Ipiranga - matérias da seção "Meu bairro", da revista Minha casa, meu imóvel (2007/2008).
POR ALEX RICCIAROI/ FOTOS MLLTOM FUKUDA

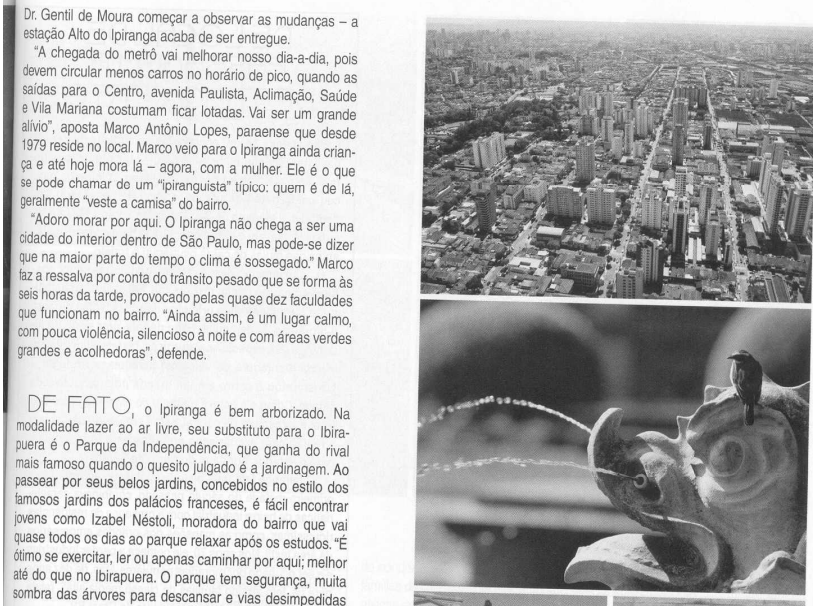

até do que no Ibirapuerara 0 parcons tomar por aqui; melhor

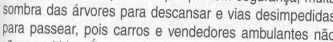

Năo bastasse a gande áre ventusiasma-se.

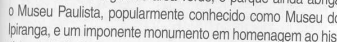

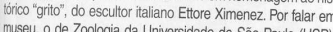

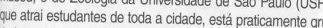

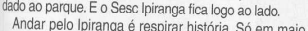

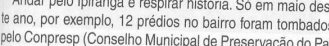

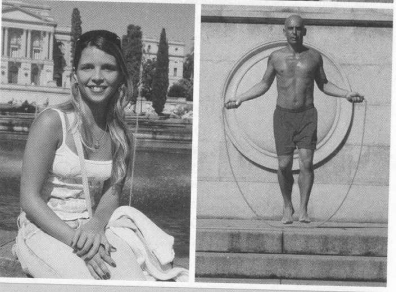

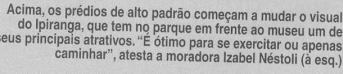




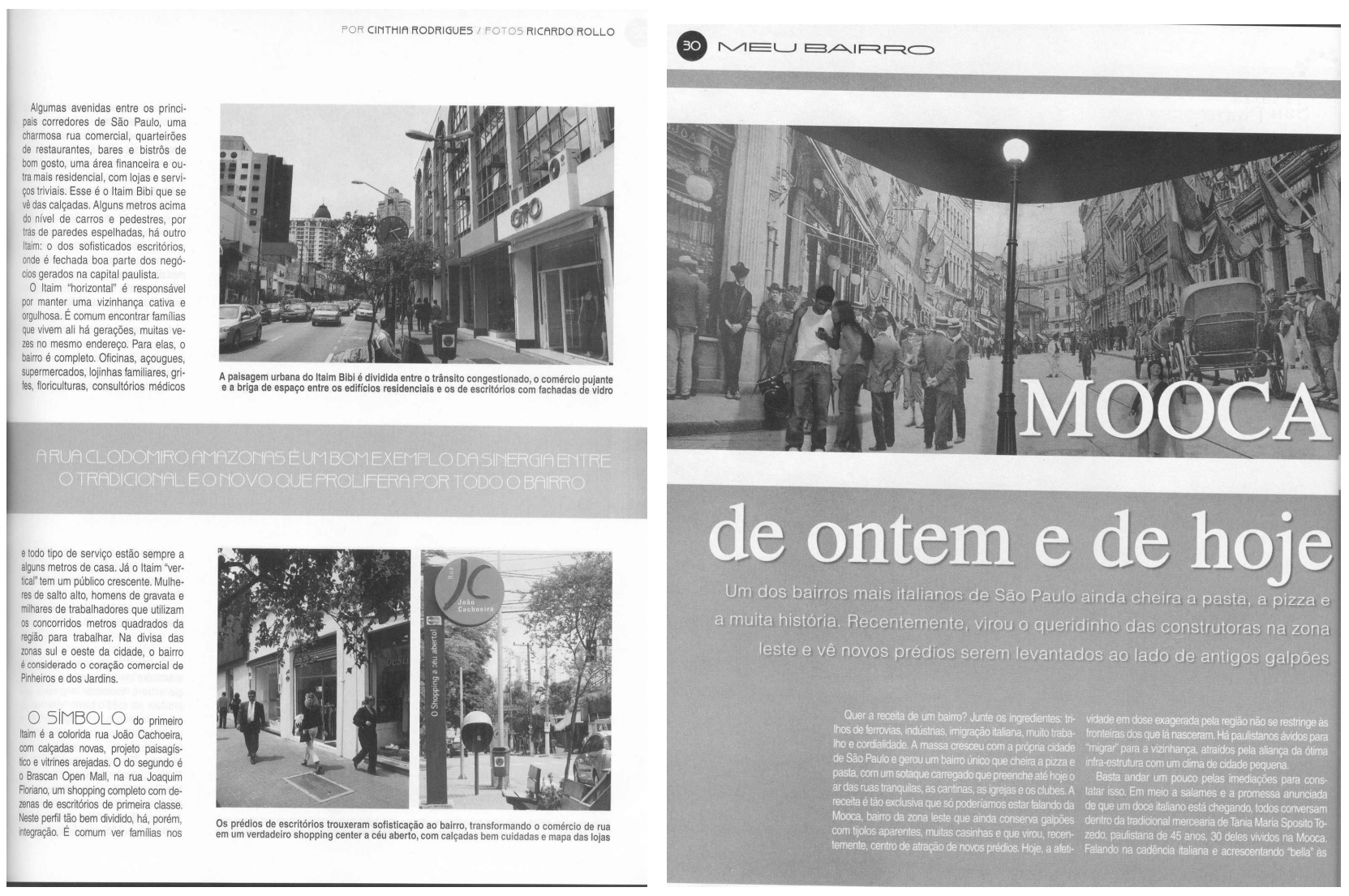

Fig. 56 - Itaim e Mooca - matérias da seção "Meu bairro", da revista Minha casa, meu imóvel (2007/2008). 


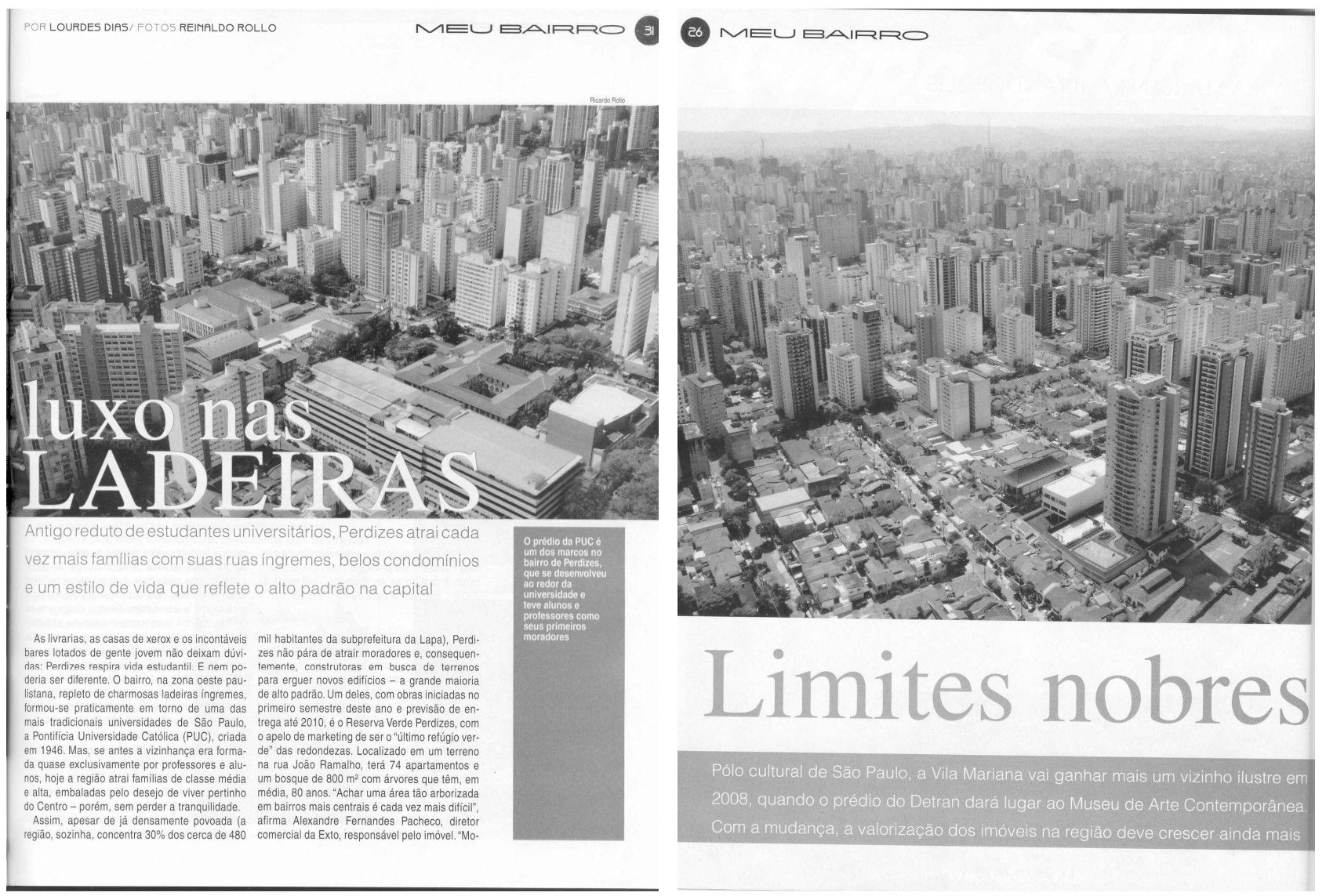

Fig. 57- - Perdizes e Vila Mariana - matérias da seção "Meu bairro", da revista Minha casa, meu imóvel (2007/2008). 
O caráter estritamente segregador das políticas públicas referentes à habitação em São Paulo teve papel determinante na atual distribuição espacial dos bairros populares na mancha urbana. As conseqüências urbanas dessas escolhas se traduzem na característica caótica que por vezes toma a cidade em seus aspectos funcionais.

Um dos objetivos deste capítulo foi demonstrar que essas escolhas políticas levaram às atuais situações de exclusão espacial, que agem como detrimento não apenas ao funcionamento da cidade como ao de toda a região metropolitana, que seguiu a mesma lógica de ocupação paulistana.

A incorporação dos cidadãos excluídos, assim como de seus locais de moradia, à vida urbana tem passado por diversas revisões nas mais diversas disciplinas: Sociologia, Economia, Administração Pública, Ecologia e outras.

$\mathrm{Na}$ área de arquitetura e urbanismo, os discursos socializantes permearam toda a discussão e produção arquitetônica desde a década de 1930 até a de 1980, sem contudo terem sido capazes de modificar a realidade espacial de seus habitantes - ao contrário, por várias razões, colaboraram para criar cenários de isolamento e precariedade, com um descompasso entre as propostas e suas concretizações.

A partir da década de 1980, com definitiva ocupação da periferia por moradias das classes mais baixas, e as grandes favelas passando a ocupar vastas áreas da cidade, as iniciativas de melhoria urbana apenas remediavam uma situação de caos instalado. A visão assistencialista dada ao problema contribuía para solidificar a realidade segregadora que foi se construindo ao longo de sucessivas décadas. 
Com os avanços alcançados na sociedade brasileira nos últimos anos, a legislação, tendo como instrumento o Estatuto da Cidade de 2001, e algumas instituições, como o Ministério Público, passam viabilizar que políticas públicas mais integradoras possam ser implantadas. Dentro dessa realidade, uma metodologia de desenho urbano para a recuperação da periferia deve ser desenvolvida para que o problema possa ser enfrentando com qualidade e de forma sustentável.

Os recursos empregados em tais intervenções são da ordem de centenas de milhões de reais, com prazos de até 10 anos. Esse recurso deve ter como retorno um espaço de qualidade para a população como um todo.

São Paulo é composta de diversos cenários sociais e espaciais, que por vezes criam realidades conflitantes e, outras vezes, realidades complementares.

A fluidez no espaço urbano na cidade só será conseguida com dois tipos de atuação: intervenções em escala metropolitana e intervenções na escala intraurbana.

Nesta última, a habitação é um dos principais instrumentos na configuração desses espaços, pois é através dela que o território, dentre suas possíveis transformações, adquire seu caráter mais duradouro, senão permanente. 
Capítulo III

Recuperação de Áreas Degradadas Destinadas ao Uso Habitacional 
A complexidade do tema (urbanização de favelas) e do contexto onde está inserida a questão habitacional estudada (região metropolitana de país periférico), aliada a mudanças bruscas no cenário econômico afeta o modo de encarar a realidade e consequentemente as intervenções nela, no caso, através das metodologias de projeto que vem sendo construídas para esse fim.

A reivindicação feita por Bueno em sua tese de doutorado (BUENO 2000 p.106) de que é necessário um maior cuidado acadêmico no estudo das urbanizações de favelas é bastante pertinente e oportuno. Sem que a autora tivesse formação específica nessa área ou de recuperação de áreas invadidas e degradadas, viu-se envolvida em projetos complexos onde tinha de tomar decisões projetuais movida pelas cobranças de toda a equipe envolvida, pelas observações de campo, pela minha criatividade e por alguma impulsividade. O estudo da questão, no entanto, me fez observar que essas dificuldades são inerentes ao processo, que minhas decisões fazem parte talvez de caráter intuitivo, e que elas vem sendo sistematicamente enfrentadas por profissionais altamente capacitados há quase 80 anos, pelo menos - no Brasil e fora dele.

As análises sistematizadas por pesquisadores como BUENO, CAMINOS, PERLMAN e VALLADARES, e análises dos projetos de que a autora participou, contribui muito para que o preconceito com relação à favela e ao seu ambiente social senão eliminado, ao menos seja minimizado, deixando mais cômodo o caminho dos arquitetos projetistas em relação ao seu fazer.

Esse é um passo importante - que já foi dado - para que o Poder Público pudesse encarar a questão da favela como um problema urbano, e passar atualizar os instrumentos de desenho urbano para enfrentar a questão. O percurso para que se tenha chegado a esse ponto foi longo e merece o 
reconhecimento desta e das próximas gerações, não apenas dos profissionais envolvidos mas da sociedade como um todo.

Este capítulo procura sistematizar algumas análises e experiências em urbanização de favelas e recuperação urbana, introduzindo o último capítulo, que descreve e analisa um projeto de Urbanização Integrada de Favela, na Favela México 70, desenvolvido pela CDHU - Companhia de Desenvolvimento Habitacional e Urbano do Estado do São Paulo, em São Vicente, que embora não na cidade de São Paulo é representativo à medida que se encontra numa região metropolitana no Estado de São Paulo.

Coloca em evidência, principalmente, o estágio de desenvolvimento do processo de projeto de urbanização de favelas, introduzindo questões que merecerão aprofundamento posterior. 


\subsection{A favela como realidade urbana}

O uso habitacional na cidade de São Paulo, como se viu nos capítulos anteriores, ia se configurando ao longo do tempo de forma bastante complexa e diversificada. A segregação sócioespacial passava a ser uma das características marcantes na paisagem urbana paulistana, assim como em diversos outros grandes centros urbanos das chamadas mega-cidades dos países emergentes.

O processo de urbanização mundial verificado entre 1800 e 1950 levou ao crescimento da população das cidades em 20 vezes, enquanto a população mundial cresceu 2,5 vezes no mesmo período. (PERLMAN, 1976 p.3) Nos ditos países do terceiro mundo, as taxas de crescimento das cidades no início da década de 1970 chegava a 5/8\% ao ano, dobrando a população a cada 10/15 anos. (PERLMAN, 1976 p.4 apud NELSON, 1969 p.1)

A lacuna entre as altas taxas de crescimento urbano, com forte contribuição da migração, e a baixa absorção da força de trabalho nos setores industriais e de serviços, aliada a baixa geração de postos de trabalho, serviços urbanos, infra-estrutura e capacidade governamental de absorção do crescimento populacional (PERLMAN, 1976 p.5) criaram condições propícias para aumentar o déficit habitacional no Rio de Janeiro, grande centros onde houve uma grande explosão de favelas na década de 1950, tendo como fenômeno paralelo o crescimento da invasão de terras para fins de moradia. A disparidade entre o grau de urbanização e de industrialização e a criação de instituições urbanas adequadas é conhecido como "overurbanization" (PERLMAN, 1976 p.5 apud FRIEDMANN, J e LACKINGTON, T.) 
Enquanto macro-soluções eram necessárias, a população foi procurando formas alternativas de geração de renda através de atividades econômicas informais. (PERLMAN, 1976 p.7) Portanto, as principais características da favela, são em sua origem, além da invasão de terras (públicas ou privadas) para fins de moradia, a informalidade das atividades econômicas de seus moradores.

Assim, a favela nascia marginalizada da cidade formal, mas ia ao mesmo tempo se consolidado como parte da vida urbana nas capitais brasileiras e em cidades médias. O Estado se via obrigado a lidar com o problema, independente de sua orientação ideológica, investindo dinheiro público quer fosse para a remoção dos assentamentos que para a sua recuperação urbana.

No posfácio de Davis (2006), Ermínia Maricato informa que "Segundo o IBGE, saímos de uma condição de contar com 10\% da população em cidades, em 1900, para $81 \%$ em 2000. A concentração urbana foi uma das características desse crescimento: 32,9\% da população urbana moram em onze metrópoles,onde estão também $82,1 \%$ dos domicílios localizados em favelas no total nacional, o que revela o caráter concentrador da pobreza urbana nas metrópoles."

Nesse ambiente social as favelas desenvolviam-se, expandiam-se e consolidavam-se nas principais

cidades

brasileiras. ${ }^{16}$

\footnotetext{
${ }^{16}$ Ver pesquisa realizada por Janice E. Perlman no Rio de Janeiro entre 1968 e 1969 sobre as favelas cariocas.
} 
As primeiras intervenções em favelas no Brasil datam dos anos 1930. Por vezes, as políticas públicas tinham o objetivo de remover totalmente os moradores favelados para conjuntos habitacionais que nem sempre eram construídos ou concluídos. Outras vezes, as políticas públicas tinham o objetivo de urbanizar a área ocupada pela favela, mantendo os moradores favelados no local. O tipo de intervenção também poderia variar: ora, se mantendo as casas e implantando redes de água e eletricidade, pavimentado-se as ruas, vielas e becos que acessavam as casas, ora as casas eram totalmente demolidas e em seu local se construíam novas moradias.

Como se viu nos capítulos anteriores, o crescimento urbano paulistano, que teve como premissa básica a segregação sócio-espacial, propiciou o surgimento de formas de ocupação habitacional alternativas ao que o mercado produzia, inacessível para as camadas de renda mais baixas da população.

As soluções habitacionais encontradas eram: 1) os loteamentos legais e distantes do centro consolidado; 2) os loteamentos clandestinos e distantes do centro urbano consolidado; 3) os cortiços nas áreas mais centrais; 4) as habitações produzidas pelo Estado e pelos Institutos de Previdência; 5) até a década de 1940, a habitação produzida pelo mercado para aluguel 6) a favela urbana.

No quadro geral, no entanto, a favela, pressupunha a invasão de terras urbanas, fossem elas públicas que privadas: "A criação de uma favela ou invasão se dá sempre de maneira coletiva.", o que contribuía para seu caráter de marginalidade. (BUENO, 2000 p.8) 
"No Brasil, morar em terra cedida ou invadida sempre fez parte das alternativas de moradia. Até os anos 30, esta era a opção que restava aos antigos escravos, lavradores sem terra e a uma parcela da população pobre, que, com a conivência do poder público, iam se assentando como podiam. As iniciativas do Estado neste campo restringiam-se, então, à adoção de uma legislação sanitária que definia a habitação salubre e a determinações de demolição e interdição de moradias consideradas insalubres, mais ou menos executadas em função das epidemias e da proximidade destas construções aos centros urbanos. Em paralelo aos cortiços e casinhas de aluguel no centro das cidades, proliferavam nas periferias os casebres e barracos." (BUENO, 2000 p.12)

"Em toda a sua história, as favelas sempre existiram a partir de uma utilização indevida do espaço, característica claramente colocada pela conceituação oficial: 'aglomerados humanos localizados em áreas não urbanizadas, constituídas por habitações rústicas ou improvisadas, desprovidas de melhoramentos públicos, construídas em terra de terceiros: do Governo, de particulares ou de domínio não definido.'" (Definição do Censo)

Com efeito, de todos os componentes desta definição, o único elemento comum a todas as favelas é a ocupação ilegal do solo. Se em algumas se encontram casas de alvenaria, em outras elementos de infraestrutura básica, em nenhuma, porém, a posse legal da terra aparece como característica."(VALLADARES, 1978 p. 30)

No Nordeste os mocambos eram construídos em áreas próximas à cidade, cedidas pelo senhor do engenho. No Rio de Janeiro, houve o caso do Morro de Santo Antônio, no final do século XIX, que foi ocupado por soldados e suas famílias com a permissão dos militares, assim como outro, o Morro da Providência, que abriram os soldados que retornaram da campanha de Canudos. (BUENO, 2000 p. 12) 
Ao longo das primeiras décadas do século $\mathrm{XX}$, as favelas foram se proliferando nas capitais brasileiras, sendo o refúgio de famílias desabrigadas por grandes obras - como no Rio de Janeiro demolição de morros, aterro de mangues, destruindo casas e cortiços, empurrando a população para os morros - no Recife, demolindo os cortiços na década de 1930, empurrando essa população também para os morros ao redor.

Os anos 1950 trouxeram a ampliação das áreas de invasão por favelas e de assentamentos precários em loteamentos populares da periferia, pelas altas taxas de crescimento populacional, de urbanização e os elevados índices de desemprego rural e urbano, que ampliaram o número de famílias de baixa renda excluídas do mercado consumidor de habitações, aliado a incapacidade do Estado e do mercado privado de produzir habitações em escala e acessíveis as diversas camadas sociais. (BUENO, 2000 p. 16)

"Ao longo dos anos 50, o habitar em favela vai se consolidando nas grandes cidades - Rio de Janeiro, Salvador, Recife - e a favela vai ganhando espaço na cultura e na sociabilidade brasileiras, com suas duas faces - fruto da inventividade de um povo que, em face da miséria, ergue a cabeça, vai morar num barraco num local ermo e produz o samba, a arte, e antro de bandidos, local de refúgio de vagabundos e criminosos. A "aceitação" da favela provavelmente tem relação com o fato de o Rio de Janeiro, onde ela desde cedo teve expressão numérica e paisagística, ser então a capital federal, de grande visibilidade em todo o Brasil, conforme observou Abreu, 1994:34: 'Abrigo da marginalidade mas também residência do trabalhador honesto: 'chaga' da cidade, mas igualmente 'berço do samba'; solução urbanística desprezada e, ao mesmo tempo, elogiada, as imagens da favela impuseram-se no decorrer do século XX e já se incorporaram ao imaginário da cidade'". (BUENO, 2000 p. 15)

No entanto, outros interesses estavam em jogo. No Rio de Janeiro, por exemplo: 
"Áreas de ocupação ilegal, de crescimento espontâneo e carentes de uma infra-estrutura básica logo, fora das normas de urbanização, as favelas sempre representaram um entrave diante dos programas de planejamento urbanos projetados ou realizados. Acresça-se a ameaça latente que também sempre representaram para o status quo, violentando a ordem estabelecida, aglomerando populações de baixa renda, de considerável importância e com corte potencial de mobilização.

Embora todas essas características transformassem as favelas em objeto passível de intervenção, o que se viu, por muitas décadas foi o desenrolar de uma política de convivência tolerante. Resultando não só dos interesses eleitorais (...), esta política também decorria da falta de recursos dos cofres públicos para empreender uma operação globalizante. De fato, tal operação demandaria altíssimas somas e um fluxo constante de recursos de que o Governo do Estado por si só dificilmente poderia dispor. Ademais, as favelas permaneceram por muito tempo ao abrigo de qualquer especulação, posto que os terrenos por elas ocupados, de propriedade de órgãos públicos ou de particulares, encontravam-se em condições topográficas de difícil exploração, ocorrendo geralmente em encostas de morros ou em terrenos alagadiços, sem contar aqueles em propriedade contestada ou desconhecida." ."(VALLADARES, 1978 p. 31) ${ }^{17}$

Esse processo de aceitação, que já completa cerca de 80 anos por todo o país, está em curso e em desenvolvimento, incentivado pelos promotores externos das políticas públicas urbanas e habitacionais.

"As agências multilaterais de suporte e financiamento de políticas públicas, como a ONU, o Banco Mundial e o BID têm dedicado grande atenção ao tema, talvez muito mais do que em décadas anteriores. Entre a década passada e os dias atuais, foram organizados vários encontros mundiais de cúpula para tratar

17 Em seu livro, Valladares estuda a operação de remoção de favelas, no Rio de Janeiro, nos anos 1970, implicando na inserção dos favelados no Sistema Financeiro de Habitação. Tratava-se, segundo ela, de um processo geral de renovação urbana da metrópole, de reorganização do uso do solo. 
da temática urbana, como o Habitat de Istambul em 1996, o Istambul +5 de 2001, e o World Urban foram 4 a realizar-se em outubro de 2008 e Nanjing,m China. Além disso, presenciou-se uma grande mudança de postura das entidades financiadoras no sentido de voltar muito mais seus investimentos nas páreas pobres das cidades do que em grandes projetos de infra-estrutura, como a havia sido a tônica até então. Sem sombra de dúvida, uma das mudanças que mais impactam na chamada nova ordem espacial urbana, como a denomina Peter Marcuse ${ }^{18}$, é a relação entre o Estado por meio de suas políticas públicas e o urbano." (DELLA NOCE, 2008 p. 14)

Céline Sachs, ([citando] SACHS, 1999) afirma que em São Paulo "... (as favelas) só se tornaram significativas na Região Metropolitana de São Paulo depois dos anos setenta. De fato, até 1972 as favelas representavam menos de $0,75 \%$ da população na cidade de São Paulo com uma população vivendo nestas condições estimada em torno de 40.000 pessoas enquanto em 1980 esse número havia subido para mais de 400.000 pessoas (4,9\% da população da cidade)... " (DELLA CROCE, 2008 p. 22)

${ }^{18}$ KEMPEN, Ronald Van; MARCUSE, Peter. A New Spatial Order in Cities? In: the American Behavioral Scientist, nov/dez 1997, 41(3), pag. 285, In: DELLA NOCE, Luiz Gustavo - O Reassentamento como promotor de capital social em políticas públicas urbanas uma análise da ação estatal em três estudos de caso - tese de doutoramento, FAUUSP: São Paulo, 2008 
A evolução das favelas no Brasil pode ser observada nas tabelas abaixo ${ }^{19}$ : Brasil: proporção de domicílios favelados por grande região

\begin{tabular}{|l|c|c|c|}
\hline Regibo & 1900 & 1991 & 2000 \\
\hline Norte & $1,04 \%$ & $4,11 \%$ & $5,32 \%$ \\
\hline Nordeste & $0,87 \%$ & $2,62 \%$ & $2,20 \%$ \\
\hline Sudeste & $2,60 \%$ & $3,59 \%$ & $4,20 \%$ \\
\hline sul & $0,62 \%$ & $1,11 \%$ & $1,30 \%$ \\
\hline Centro Oeste & $0,58 \%$ & $0,42 \%$ & $0,44 \%$ \\
\hline Brosil & $1,62 \%$ & $2,76 \%$ & $3,04 \%$ \\
\hline
\end{tabular}

Fonte: Censos Demográficos 1980, 1991 e 2000

19 PASTERNAK, Suzana - A favela que virou cidade - Urban Research Symposium, 2005 http://www.worldbank.org/urban/symposium2005/presentations/Pasternak.pdf 


\section{Brasil: taxas geométricas de crescimento dos domicílios totais}

\begin{tabular}{|c|c|c|c|c|}
\hline \multirow[t]{2}{*}{ Regibo } & \multicolumn{2}{|c|}{ Domicilios totais } & \multicolumn{2}{|c|}{ Domicilios favelados } \\
\hline & 1980-1991 & $1991 \cdot 2000$ & 1980-1991 & $1991-2000$ \\
\hline Norte & $6,25 \%$ & $3,90 \%$ & $20,37 \%$ & $6,91 \%$ \\
\hline Nordeate & $2,23 \%$ & $2,73 \%$ & $13,66 \%$ & $0,76 \%$ \\
\hline Sudeste & $2,90 \%$ & $3,06 \%$ & $5,96 \%$ & $4,89 \%$ \\
\hline Sul & $2,209 \%$ & $2,87 \%$ & $8,44 \%$ & $4,65 \%$ \\
\hline C. Oeste & $3,54 \%$ & $4,03 \%$ & $0,64 \%$ & $4,55 \%$ \\
\hline Brasil & $3,08 \%$ & $3,05 \%$ & $8,18 \%$ & $4,18 \%$ \\
\hline
\end{tabular}

Fonte: Censos Demográficos 1980, 1991 e $2000^{20}$

${ }^{20}$ PASTERNAK, Suzana - A favela que virou cidade - Urban Research Symposium, 2005

http://www.worldbank.org/urban/symposium2005/presentations/Pasternak.pdf 
Quando o Poder Público opta por manter a população favelada em seu local de origem, inicia-se um longo processo de escolhas coletivas as mais diversas.

A manutenção da população em seu local de origem é uma das mais fortes justificativas para a intervenção em grandes favelas urbanas, a despeito de várias críticas em relação ao beneficiamento de uma dada população em relação ao total da cidade com dinheiro público. (BUENO, 2000 p.74-78)

No entato, a informalidade, o sub-emprego e a pobreza absoluta nas áreas urbanas estavam na agenda política e econômica da década de 1990: "Suas diretrizes apontam, por um lado, para um mercado de terras funcional e um Estado enxuto, na linha do Consenso de Washington no início da década de noventa. Mas por outro lado, cresceu e muito a conscientização por parte dos tomadores de decisão em diversas instâncias sobre a necessidade de se potencializar os processos de empoderamento local e parceria Estado-sociedade." (DELLA NOCE, 2008 p. 23)

Isso se deu, segundo Ermínia Maricato em posfácio de Davis, (2006) porque "O marketing urbano e o modelo do 'plano estratégico' fizeram parte das pirotecnicas utilizadas para reverter um processo de deteriorização urbana. Entretanto, o rumo adotado começou a fazer água com o crescimento da pobreza, e as críticas começaram a vencer a barreira do 'pensamento único'. O Crescimento previsto na receita aplicada não aconteceu.

A correção de rota do Consenso de Washington foi apontar a necessidade de se encarar a esfera política. [...] Trata-se de defesa de uma democracia local e fragmentada, combinada a políticas sociais focadas".(DAVIS, 2000 p. 217)

Essa escolha foi passando por diversas etapas ao longo da urbanização brasileira, evidente no comentário de Parisse (1969) sobre o caso do Rio de Janeiro: "é significativo acompanhar a 
evolução do vocabulário para designar a 'solução' do problema favela: a ação idealizada por Vítor de Moura ${ }^{21}$ se exprime na palavra: 'substituição'. Seus sucessores, nos serviços da Prefeitura, a partir de 1947, falam em 'extinção' e depois em 'recuperação da favela'. Depois de 1950, impõem-se os termos curiosos de 'salvação' da favela, 'redenção', e fala-se da 'vocação messiânica' dos que se consagram a 'salvar' a favela. Enfim, por volta de 1952-1953 aparece o uso da palavra, hoje tão comum, de 'urbanização'. Pedimos ao leitor, mais uma vez, que se utilize do 'espritt de finesse' tão necessário a quem estuda a favela: estes termos caracterizam uma etapa histórica da favela, mas não são estritamente privativos dela." (BUENO, 2000 p. 167)

No entanto, na prática, a manunteção da comunidade local não implica na manunteção de todos os moradores:

"Mesmo em ações de urbanização de favelas é necessário remoção de famílias. Segundo DENALDI (2003), o alto adensamento das favelas tornou necessário remover maior percentual de famílias para viabilizar a urbanização sem abrir mão da fração mínima de terra (lote mínimo) por família. Isso representa uma parte significativa da população residente no núcleo que deverá ser removida para outros empreendimentos habitacionais." (DELLA NOCE, 2008 p. 27)

A manunteção da comunidade no local tem implicações que vão além de manter-se na casa: "Para o morador, a favela é uma solução do problema de sobrevivência (...) e dos baixos salários. A preocupação do favelado não é a casa, ele quer muito mais. O problema da habitação em si é mais problema da Administração, da cidade, do que do favelado. Assim, os favelados procuram garantir sua localização e certo acesso a serviços básicos água, luz. Os administradores e técnicos procuram propostas de política

${ }^{21}$ Em nota, BUENO(2000) p. 167 comenta que Vitor de Moura implementou as remoções dos mocambos de Recife e, também nos anos 40, esteve dando sua contribuição numa Comissão da Capital Federal sobre as favelas. 
urbana para a favela que tornem coerentes essas reivindiações de 'urbanizar' a favela, trazendo-a para a cidade.

No Rio de Janeiro, a opção pelo direito à localização é feita, primeiramente, pelo Departamento de Habitação Popular da Prefeitura, chefiado pela Engenheira Carmen Portinho a partir de 1946. Inspirada na reconstrução do pós-guerra da Europa, que acompanhara, baseada em grande produção habitacional, fez-se opção por demolir todos os barracos e construir prédios em favelas, essa era a idéia original no caso dos parques proletários, no Rio dos anos 40 e 50.

Reidy inspirou-se nessa concepção em seus conjuntos habitcionais. Os Projetos (desenvolvidos pelo Departamento de Habitação Popular da Prefeitura do Rio de Janeiro) Pedregulho, Conjunto Marquês de São Vicente e Catacumbas localizam-se em encostas íngremes onde já havia ocupantes." (BUENO, 2000 p. 167/168)

No Rio de Janeiro, em 1955, D. Helder Câmara criou a Cruzada São Sebastião, que barrou algumas remoções de favelas e promoveu em 1957 o primeiro Congresso de Favelados do Rio de Janeiro. A primeira experiência de urbanização se deu no Parque da Alegria, no seu próprio local. No Leblon, a Cruzada participava da implementação dos parques proletários, removendo favelados oferecendo prédios residenciais. A favela Morro Azul constituiu um dos primeiros exemplos de urbanismo na maior parte da encosta, com a remoção parcial de parte da população, contando com a construção de um prédios para abrigar os moradores desalojados. (BUENO, 2000 p. 169)

Um escritório de arquitetura, o Quadra Arquitetos Associados (formado por Carlos N. Ferreira dos Santos, Rogério Aroeira Neves, Sylvia Maria L. Wanderley e Sueli Azevedo), em 1966, foi contratado pela Federação de Favela do Estado da Guanabara para estudar as favelas de Catumbi e Brás de Pina. 
"A partir do levantamento do assentamento original de Brás de Pina, o projeto foi elaborado considerando estudos de relocação de casas para abrir ruas e para saneamento, tirando-se partido de um terreno vago que existia ao lado da favela, o que serviu como pulmão para as primeiras relocações. As casas, que eram todas de madeira, eram desmontadas e transferidas para o local definitivo, onde haviam sido feitas as obras de aterro, drenagem e esgotamento." (BUENO, 2000 p. 171)

A questão do projeto das urbanizações começou a ser discutida dentro da universidade através da reflexão quanto ao desenho urbano das favelas, e alternativas de remodelação além da remoção. A legislação urbanística (tamanho dos lotes, recuos, dimensão das vias etc), no entanto, não podia ser seguida, tornando os projetos irreprodutíveis na estrutura da administração pública de gestão urbanística e habitacional. (BUENO, 2000 p. 173)

BONDUKI (1986 p. 106-107) relata a experiência desenvolvida em São Paulo, no Laboratório de Habitação da Faculdade de Arquitetura Belas Artes, para o Recanto da Alegria: "Por vias diversas, equipe técnica e moradores concordaram com a diretriz básica do plano de urbanização: não destruir totalmente as característias espaciais pré-existentes. Estas eram fruto da espotaneidade da ocupação do local e da não definição rígida entre o espaço privado e o coletivo. Os becos, os cantos, e recantos, o estreitamento e alargamento das vielas configuradas pelas construções e a irregularidade dos alinhamentos criavam uma morfologia urbana muito rica, que não devia desaparecer apesar da necessidade de reconstruir todas as casas, de estruturar o sistema viário e redes de infraestrutura e definir o lote de cada um, exigência reivindicada por todos." (BUENO, 2000 p. 175)

Essa opção foi a assumida pela Prefeitura de São Paulo nos anos 1980: demolição, reparcelamento e reconstrução total, em função da precariedade dos barracos. Segundo análise de BUENO (2000 p. 178) "... até os anos 80 também induzia a uma tentativa de desenvolver soluções como as 
unidades mínimas de apartamento para o desfavelamento. Mas algumas invasões tinham que ser demolidas e reconstruídas pelas condições fisiográficas. É o caso das favelas em mangues e várzeas (...). Aqui a condição hidrológica e geotécnica indica como solução as ações de demolição, aterro, infra-estrutura e, finalmente, a reconstrução das casas. (BUENO, 2000 p. 178)

Um outro exemplo também citado é da favela dos Alagados, em Salvador, onde foi necessária a execução de um reaterro para construção das unidades habitacionais, Nova Alagados, também em Salvador, região de São Pedro, área de mangue em Vitória, que a partir do início dos anos 1980 iniciou as obras de remoção, consolidação de aterro, reocupação e recuperação ambiental. Segundo BUENO (2000 p. 179) foi criada uma Estação Ecológica, na Ilha do Lameirão, e uma usina de tratamento de lixo, empregando os moradores.

Com o desenvolvimento dos processos de projetos e intervenção em favelas, algumas metodologias foram se configurando com maior força por diversas administrações públicas, em São Paulo, por exemplo.

Em todas elas, a questão da infraestrutura básica é presente e pouco ou quase nada envolve os habitantes. Em alguns casos se restringe a infraestrutura básica de atendimento apenas à população local.

Há casos, no entanto, que contam com a instalação de equipamentos de uso mais regional dentro da malha urbana - escolas, usina de tratamento de lixo, equipamentos esportivos, parques, quadras. Nesse caso a comunidade passa a ter um envolvimento maior, inclusive, com a geração de renda como nos exemplos citados em Salvador, em Nova Alagados. 
A pesquisadora Laura Bueno em sua tese de doutorado procura elencar uma série de experiências brasileiras das quais tira algumas recomendações para projeto.

Outro estudo de importância será apresentado a seguir, desenvolvido pelos pesquisadores Horacio Caminos e Reinhard Goethert, a partir de 1976 a partir de várias experiências mundiais, com financiamento do Banco Mundial ao longo da década de 1980.

Recentemente (a partir de 2007), o Governo do Estado de São Paulo, por meio da Secretaria Estadual da Habitação e da CDHU (Companhia de Desenvolvimento Habitacional e Urbano) vem incrementando os investimentos na recuperação urbana de favelas e de outros tipos de assentamentos precários. Segundo declaração do então secretário da Habitação em publicação institucional publicada em janeiro/2009 ${ }^{22}$, para o enfrentamento do déficit habitacional no Estado: "A regularização fundiária é tão importante quanto a construção de novos empreendimentos. (...) ... adotamos medidas importantes para assegurar às famílias a localização de seu imóvel e o registro da propriedade a custos acessíveis para a população de baixa renda.

Um dos grandes trunfos na luta contra a falta de moradia para classes menos favorecidas é o fomento à participação da iniciativa privada no mercado de habitação popular (...) Entretanto, o combate ao déficit habitacional transcende a construção de moradias. Inclui também a requalificação das existentes, a urbanização de favelas e a recuperação ambiental. Nossas ações dão suporte às obras estruturais do Governo do Estado com o reassentamento de famílias que vivem em áreas de risco ou de preservação.

22 Panorama da Habitação de Interesse Social - Governo do Estado de São Paulo - Secretaria da Habitação/CDHU $2007 / 2008$ 
Assim, transformamos núcleos precários em bairros legalizados e urbanisticamente recuperados." (KRÄHENBÜHL, 2009)

Com isso, a sociedade vai paulatinamente evoluindo num consenso em relação à inclusão social e econômica das parcelas desfavorecidas da sociedade/cidade. 
O enfoque com relação às políticas públicas e políticas habitacionais veio, ao longo dos anos 1990, tomando uma forma mais coesa, abordando problemas habitacionais, relacionados aos demais problemas citadinos.

"Segundo BRAKARZ (2002), foi a ONU em seu documento 'A Global Shelter Stragey Towards the Year 2000' de 1998 que originalmente abordou a política habitacional de forma integrada, priorizando o funcionamento do mercado como principal agende facilitador da eficiência das políticas urbanas. $O$ documento da ONU acabou sendo incorporado pelo Banco Mundial na sua publicação 'Housing Enabling Markets to Work' (1993)

Essa nova estrutura política propõe sete linhas de ação no encaminhamento da questão habitacional:

- Desenvolver direitos de propriedade, assegurando que os diretos de posse e o livre mercado de habitação seja estabelecidos e cumpridos por lei, além de desenvolver programas de regularização fundiária;

- Desenvolver o financiamento, criando instituições confiáveis e competitivas, e propondo ações inovadoras para promover maior acesso ao financiamento habitacional para baixa renda;

- Racionalizar subsídios, assegurando que programa de subsídios esteja dentro de uma escala apropriada e viável economicamente bem orientada, mensurável e transparente, evitando a distorção do mercado de habitação;

- Prover infraestrutura para o desenvolvimento habitacional e urbano, coordenando agências responsáveis pela provisão de infra-estrutura residencial (sistema viário, drenagem, água, esgoto e eletricidade), enfocando nos serviços existentes e áreas urbanas carentes;

- Regulamentar o desenvolvimento fundiário e habitacional, balanceando custos e benefícios das regulamentações que influenciem os mercados de terra e habitação, 
especialmente uso do solo e códigos de obras, e remover regulamentações que atravanquem

o suprimento de habitações;

- Organizar a indústria da construção, criando mais competição e removendo barreiras ao desenvolvimento e uso de materiais de construção locais, e reduzindo barreiras sobre insumos da habitação;

- Fortalecer instituições que possam monitorar e gerenciar o setor como um todo, unindo as agências públicas com o setor privado, ONGs representativas e organizações comunitárias, assegurando que as políticas beneficiarão os mais pobres e garantirá sua participação." Apud WORD BANK, 1993

Como se vê, é uma estratégia fundamentalmente de mercado no encaminhamento da questão, principalmente no que se refere ao ajuste e flexibilização da legislação para atividades econômicas ligadas à habitação, apoio à indústria e adoção de financiamento. Mas, além disso, significou também uma mudança na linguagem das políticas públicas, da provisão habitacional para a qualidade dos assentamentos humanos dentro de soluções integradas)" (DELLA NOCE, 2008 p. 37-38 Apud BRARKAZ, 2002)

Essas podem ser vantagens e oportunidades no desenvolvimento de metodologias originais de projeto para o enfrentamento das questões de habitação na cidade, indo além de soluções apenas quantitativas, mas lidando com a qualidade e significado da moradia para seu ocupante.

De um modo geral, as intervenções de recuperação urbana, seja nas áreas das favelas seja em áreas carentes da periferia, requerem dos administradores públicos e dos projetistas envolvidos uma clara definição. Poderíamos tomar emprestado os seguintes conceitos: 
"A revitalização/requalificação ensejaria uma maneira menos traumática - ou mais respeitosa - de transformar a cidade, que procuraria compreender e interagir com o contexto do ambiente a ser alterado. Nesse sentido, o respeito à tradição da comunidade e à cultura local, a atenção às relações da área com seu entorno e aos laços sociais existentes seriam alguns dos pressupostos básicos para o planejamento e a ação.

O termo 'reabilitação' tem sido encampado' mais recentemente por determinados autores para expressar um modo de intervenção urbana voltado à superação dos passivos ambientais e econômicos resultantes de um histórico de industrialização pouco preocupado com suas externalidades negativas. A reabilitação teria como metas a devolução das áreas impactadas ao ciclo econômico da cidade e o desenvolvimento urbano sustentado." (VALENTIM, 2005, p. 87)

No caso de São Paulo, a periferia populosa encontra-se em área ambientalmente frágil por se tratar, a sudoeste e norte, dos mananciais que abastecem o município, junto as Serra do Mar e Serra da Cantareira e, a leste, da várzea do rio Tietê.

Não se pode pensar em programas habitacionais sem que se leve em conta as questões ambientais.

Um exemplo atual (2007) é o Programa de Recuperação Socioambiental da Serra do Mar, em fase de implementação pelo Governo do Estado de São Paulo por ocasião da elaboração da presente pesquisa.

"Por mais de 40 anos, as encostas da serra foram sendo ocupadas irregularmente às margens das rodovias que cortam a região, como a Via Anchieta. O crescimento populacional e urbano deu origem aos famosos bairros cota e a outros núcleos habitacionais irregulares em áreas que pertencem ao Parque Estadual da Serra do Mar (PESM), no Município de Cubatão, a maior área contínua de Mata Atlântica preservada no Brasil. 
O crescimento dos assentamentos humanos na serra, alguns precários e outros consolidados, ameaça esse importantíssimo ecossistema e potencializa o risco de acidentes geológicos, como escorregamento de terra e rochas, que põem em perigo a vida de milhares de pessoas. O processo de ocupação irregular resultou, inclusive, na poluição do Rio Cubatão, que abastece boa parte das cidades da Baixada Santista.

Pare recuperar e proteger esse patrimônio, foi desenvolvido o Programa de Recuperação Socioambiental da Serra do Mar e dos Sistemas de Mosaicos da Mata Atlântica. O programa é composto por intervenções integradas nas áreas de Habitação e de Meio Ambiente, entre outras, que vão promover moradias seguras, em bairros com infraestrutura completa, preservar o parque e demais remanescentes da Mata Atlântica e gerar ações de sustentabilidade socioambiental e econômica nos novos bairros onde serão reassentadas as famílias e nas áreas que serão urbanizadas." 23

As discussões sobre as questões ambientais têm se ampliado significativamente com a introdução do conceito de sustentabilidade. De forma sucinta, por sustentável entenda-se o ecologicamente correto, economicamente viável, socialmente justo e culturalmente aceito. Como expôs António Baptista Coelho, presidente da Federação Nacional das Cooperativas de Habitação Económica (FENACHE), de Portugal:

"Esta idéia de 'construir no construído' constituí, em si mesma, uma base fundamental de sustentabilidade urbana, física e social, pois trata de se privilegiar a intervenção seja na reabilitação de determinadas parcelas da cidade, tornando-as novamente úteis e atenuando-se a expansão da cidade sobre o meio natural, mas também se refere ao importante de se privilegiar o preenchimento, a colmatação e o cerzir do espaço urbano preexistente. $O$ 'construir no construído' tende a anular os espaços residuais e marginais, a rentabilizar as infraestruturas já instaladas, a avançar na anulação de zonas social e por vezes

\footnotetext{
23 Ver Panorama da Habitação de Interesse Social - Governo do Estado de São Paulo - Secretaria da Habitação/CDHU -
} 2007/2008 p. 37 
ambientalmente problemáticas, e associa-se naturalmente, devido à sua própria natureza, que favorece intervenções em escala relativamente reduzida, ao privilegiar das intervenções pequenas e expressivamente humanizadas, aspectos estes que se consideram, hoje em dia, estruturantes." (COELHO, 2007, p. 19)

Os conceitos inicialmente empregados nas urbanizações de favelas passam a formar um arcabouço de conhecimento e metodologias ainda não acabadas aplicáveis em recuperação urbana de áreas degradadas.

Deve-se atentar também para o seguinte aspecto: o Poder Público, ao intervir em áreas irregulares, além de recuperá-las urbanistica, ambiental e socialmente, tem o papel de regularizálas. A possibilidade de intervenção pelo Estado em área irregular não se dá em áreas igualmente degradadas, mas regulares do ponto de vista fundiário. Em geral, as áreas urbanas onde se localizam as favelas possuem um entorno igualmente precário. A solução integrada deve se ampliar de tal forma a englobar esse entorno.

No entanto, a organização da população e sua participação no processo é fundamental. Ter como foco a autonomia das comunidades e uma interação em rede em toda a cidade é o esperado e desejável para se ampliar as redes sociais, como recomendam Caminos e Goethert, em trabalho de 1976, Della Noce, em trabalho de 2008 e Bueno, em trabalho de 2000. 

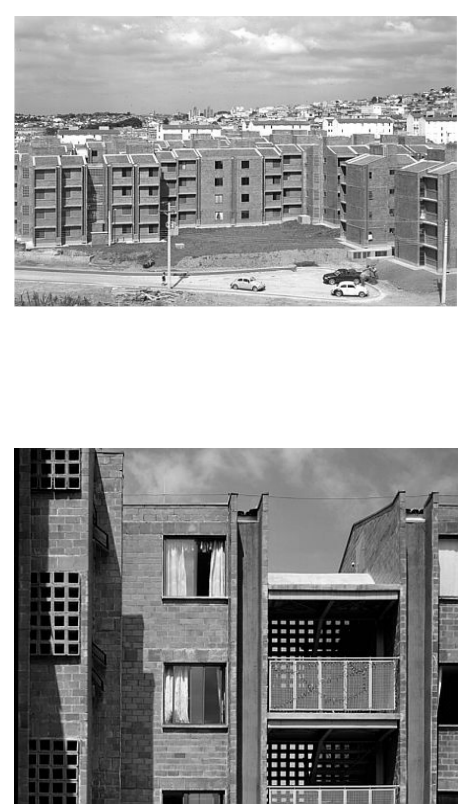

Fig. 58 e 59 - Fazenda da Juta Sapopemba - edifícios construídos por sistema de mutirão (participação direta dos moradores na construção) CDHU , 2006
Mesmo compiladas diversas experiências, o início do processo de projeto de urbanização de sítios urbanos consolidados, mas precários, é sempre um grande desafio.

Por trazer em si vários estereótipos e mitos, a favela apresenta-se como um grande enigma para os projetistas e urbanistas. No entanto, é necessário aproximar-se dessa realidade de forma mais realista e direta.

O método de pesquisa conduzido por Janice Perlman nas favelas do Rio de Janeiro entre 1968 e 1969 tem um viés fortemente antropológico e qualitativo. A coexistência com a população e sua Observação Participativa ao tornar-se moradora da favela permitiram a pesquisadora "vivenciar o que eles vivenciam e trabalhar dentro do sistema de referência deles". (MARCONI, LAKATOS, 2008 p. 277) A pesquisadora ainda se valeu para a coleta e análise de dados, da aplicação de questionário e sua confirmação em campo e posterior tabulação e tratamento estatístico. (PERLMAN, 1976)

Esse tipo de aproximação tem como possibilidade a quebra de vários mitos em relação aos favelados e suas comunidades. A quebra mostra que as características sociais dessa população em muito se assemelha a da população das classes médias de renda, se diferenciado pela precariedade das condições físicas.

Embora os dados coletados nessa pesquisa se refiram a favelas do Rio de Janeiro, entre os anos 1968 e 1969, a metodologia utilizada e alguns resultados interessam como base para propostas atuais. As visitas de campo são fundamentais, feitas pelas equipes de projetos e não apenas encomendados a pesquisadores autônomos. A interpretação 'antropológica' do urbanista é necessária, como se verificará mais adiante na experiência desenvolvida em 2007, na favela México 70, no Município de São Vicente, São Paulo, pela CDHU. 
Ainda que a realidade socioeconômica dos favelados tenha mudado e que São Paulo tenha

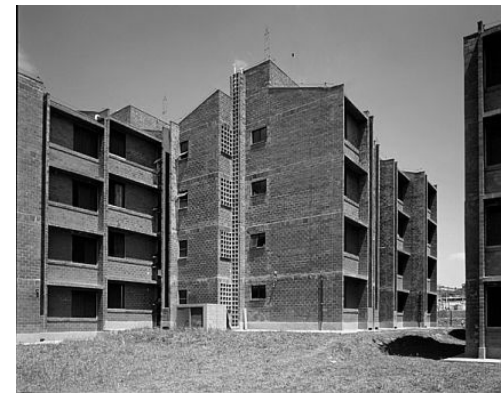
tido uma dinâmica um pouco diversa do Rio de Janeiro, como atestam as seguintes tabelas ${ }^{24}$, algumas conclusões a que Janice Perlman chegou em sua pesquisa na década de 1960 podem ser tomados como ponto de partida para projetos de urbanização de favelas na capital paulista.

\section{Favelas do Município de São Paulo: Evolução da infraestrutura, em percentual}

\begin{tabular}{|c|c|c|c|c|c|c|}
\hline indicador & 1973 & 1900 & 1907 & 1991 & 1993 & 2000 \\
\hline Agua encanada & $\cdot$ & 33,0 & 92,4 & 89,6 & $\cdot$ & 98,1 \\
\hline Agua rede publica & $\cdot$ & 22,6 & $\cdot$ & 85,2 & $\begin{array}{c}64,2 \text { ind } \\
13,0 \\
\text { col } \\
73,1 \text { total }\end{array}$ & 98,1 \\
\hline Rede publica de eagoto & 0,7 & 0,6 & 19,3 & 26,0 & 12,1 & 51,0 \\
\hline Energia el etrica & $\cdot$ & 65,4 & 98,0 & 99,6 & 90,0 & 99,0 \\
\hline Coleta de lixo regular & 15,1 & 42,8 & 72,3 & 63,0 & 88,4 & 80,2 \\
\hline
\end{tabular}

Fig 60 e 61 - Fazenda da Juta -

Mutirão - CDHU, 2006

Fonte: Censos Demográficos 1980, 1991 e 2000

24 PASTERNAK, Suzana - A favela que virou cidade - Urban Research Symposium, 2005 http://www.worldbank.org/urban/symposium2005/presentations/Pasternak.pdf 


\section{Favelas do Município de São Paulo: Evolução das condições materiais}

dos domicílios, em percentual

\begin{tabular}{|c|c|c|c|c|c|c|}
\hline indicador & 1973 & 1900 & 1907 & 1991 & 1993 & 2000 \\
\hline Poredes extema alvenaria & 1,3 & 2,4 & 50,5 & 66,4 & 74,2 & r \\
\hline $\begin{array}{ll}\text { Paredes } & \text { intemas } \\
\text { improvisadas }\end{array}$ & 52,2 & 24,5 & 14,8 & . & 33,7 & . \\
\hline Piso terra batida & 46,3 & 17,7 & 7,43 & 6,5 & 4,5 & $\bar{*}$ \\
\hline $\begin{array}{l}\text { Cobertura } \\
\text { madeirailmprovisada }\end{array}$ & 26,3 & 21,7 & 1,90 & - & 2,4 & - \\
\hline $\begin{array}{l}\text { Sem banheiro ou banheiro } \\
\text { coletivo }\end{array}$ & 65,0 & 44,3 & 13,6 & & . & 2,3 \\
\hline Sem sanitarlo individual & 35,8 & 25,00 & $\cdot$ & 12,6 & 7,5 & 0,3 \\
\hline
\end{tabular}

Fonte: Censos Demográficos 1980, 1991 e 2000

No início do século XXI, a favela é uma realidade aceita e diversos governos, independentemente de sua orientação ideológica, tem contribuído para o desenvolvimento da atuação dos Governos Municipais nos Projetos de Urbanização.(BUENO, 2000 p. 54-158)

Não seria excessivo, no entanto, clarear o perfil do favelado, que ao longo do tempo só avançou no sentido de conquistas de direitos de cidadão. 
Como o projeto de urbanização de uma favela é um projeto coletivo, em que uma das principais riquezas é aquela criada pelo Capital Social ${ }^{25}$ ali instalado, conhecer essa comunidade e suas dinâmicas passa a ser fundamental para orientar a tomada de decisões quanto às feições que o projeto urbano irá assumir.

Perlman (1976) contatou alguns estereótipos e mitos sobre a Marginalidade ${ }^{26}$ social, cultural e econômica de favelados no Rio de Janeiro da década de 1960 em sua pesquisa tais como:

1. Isolamento Interno dos moradores de uma favela, pois encontrou fortes laços de coletividade e relacionamentos de amizade entre os moradores, assim como um alto grau de confiança e unidade entre eles (PERLMAN, 1976 p. 132-133)

2. Isolamento Externo dos favelados, uma vez que mantinham grande contato com a estrutura urbana mais ampla, além do entorno da favela, através de atividades como compra de comida, roupa, escola para os filhos, saúde, etc, além do contato com os valores de classe média trazidos pelos meios de comunicação em massa. Comenta que, em pesquisa de Lisa Peattie, a realidade dos favelados em Ciudad Guayana, Venezuela, os moradores se vestiam como os

25 Para Della Noce (2008) "... o capital social não é associado ao indivíduo isoladamente nem tampouco à infraestrutura técnica presente no espaço, mais que isso, é formado pelas normas, valores, instituições e relacionamentos compartilhados por vários indivíduos numa comunidade qualquer, e que permitem a participação e cooperação dentro e entre diferentes grupos sociais. Fica evidente aqui o papel das redes sociais no conceito de capital social: trata-se de um recurso da comunidade que, por meio da construção de sua teia de relações, constitui uma estrutura definidora de normas, valores e fluxos de informação e recursos." (DELLA NOCE, 2008 p. 89)

${ }^{26}$ Para aprofundamento do conceito de Marginalidade, ver PERLMAN, J. The Myth of Marginality University of California Press - London - 1976.p. 91; Ver também The metamorphosis of marginality: the favelas of Rio de Janeiro: 1969-2002 - WBI, onde a pesquisadora continua sua pesquisa entrevistando as crianças, filhas dos moradores das favelas pesquisadas em 1969. (http://www.worldbank.org/urban/upgrading/docs/janice-paper.txt) 
moradores do restante da cidade e suas casas possuíam um 'estilo das pessoas pobres da cidade'. (PERLMAN, 1976 p. 136-137)

3. Os Termos da Integração Social dos favelados que, no entanto, não se davam de forma favorável a eles pois não possuíam um tratamento adequado nos órgãos públicos de assistência social, dentre outros. Sua adequação social sofre barreiras de classe, não tendo as mesmas oportunidades, respeito e bem estar do qual a classe média gozava (PERLMAN, 1976 p. 14 apud BOSCHI e GOLDSCHMIDT, 1970 p. 109)

4. A cultura da tradicionalidade que se caracteriza pela religiosidade, suscetibilidade à inovação, orientação familiar e empatia. O que foi mostrado em sua pesquisa, como se vê nos dados, é que o contato dos migrantes com a vida urbana diminuiu os apelos religiosos em relação a sua condição de vida; mostraram simpatia com os avanços da ciência e o controle da natalidade (PERLMAN, 1976 p. 143-146)

5. As famílias desfeitas. $90 \%$ dos entrevistados era membro de famílias nucleares, demonstrando que a taxa de famílias desfeitas era muito baixa;

6. Pessimismo e frustração, que os favelados combatiam com um alto grau de otimismo (PERLMAN, 1976 p. 146)

7. Os Termos da Integração Cultural mostram que o favelado era sistematicamente excluído das oportunidades escolares em todos os níveis (PERLMAN, 1976 p. 136-149)

8. [...]

9. Parasitismo econômico - de acordo com a pesquisa, ainda que mal remunerados, sub-empregados ou não registrados, os favelados desempenhavam um importante papel na 
economia urbana externa à favela, fazendo serviços que ninguém queria fazer como empregada doméstica, porteiro, jardineiro, pedreiro, gari, motoristas, etc. Além disso construíam suas próprias casas e proporcionavam melhoramentos urbanos como pequenos arruamentos, encaminhamento de esgoto e águas pluviais, etc, movimentando cerca de 180 milhões de dólares (convertidas nas taxas de 1969) somando-se as 200 mil famílias faveladas em todo o Rio de Janeiro (PERLMAN, 1976 p. 152-154)

10. Estreiteza de horizontes econômicos - segundo a pesquisa, embora o favelado não tivesse muitas habilidades intelectuais e proficiência em serviços técnicos, tinham condições de participar, segundo a pesquisadora, de participar do mundo moderno pela abertura por inovações, aspiração por educação, crença no trabalho duro e aceitação da ciência moderna. (PERLMAN, 1976 p. 156)

11.Termos da integração econômica - os favelados se integravam à economia através dos trabalhos que não exigem qualificação, mantendo assim baixos os níveis salariais, muitas vezes em empregos informais, não utilizando os serviços públicos por falta da formalidade dos empregos (PERLMAN, 1976 p. 160)

Concluindo-se: o favelado era integrado a sociedade, ainda que de forma precária, e muito suscetível aos humores econômicos.

Ao longo dos anos, a realidade do favelado se alterou. Embora não tenham sido freqüentes desde a década de 1970, os períodos de crescimento econômico, ao melhorarem os níveis de renda dos favelados, propiciaram uma melhor inserção social, diminuindo a precariedade de sua condição. (PASTERNEK, 2005) 
3.6 Algumas experiências de Projetos de Urbanizaçăo de Favelas

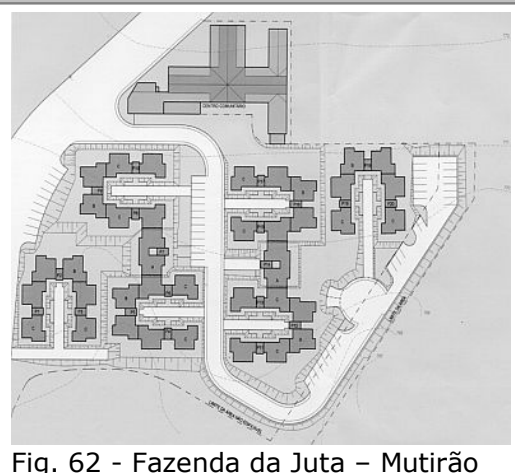

CDHU, 2006 (Projeto Usina).

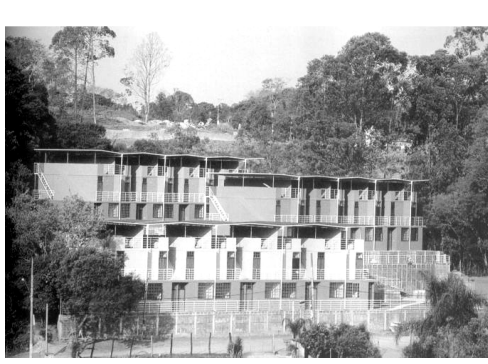

Fig. 63 - Condomínio em Cotia, SP - Juan Villà, 2003.

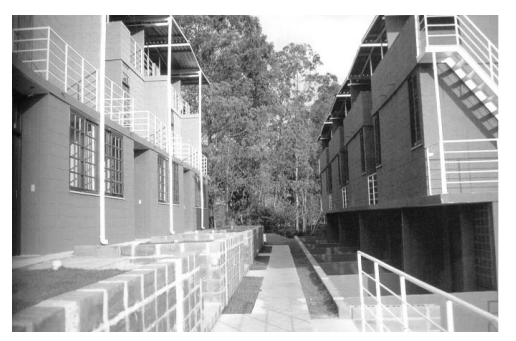

Fig. 64 - Condomínio em Cotia, SP - Juan Villà, 2003
A sistematização de experiências e análises feitas durante o processo de elaboração, implementação e pós-ocupação de urbanizações em várias cidades no Brasil (Rio de Janeiro, Belo Horizonte, Vitória, São Paulo, Santo André, Diadema) e em diversos outros países (Cidade do México, México; Istambul, Turquia; Ankara, Turquia; Bangkok, Tailândia; Beirute, Líbano; Boston, Estados Unidos) tem sido a forma de se compilar documentos para elaboração de referência que possa ser utilizada como balizas de projetos futuros.

Um material desenvolvido no programa em Desenho Urbano de Assentamentos em Países em Desenvolvimento, realizado pela Escola de Arquitetura e Planejamento, Massachussetts Institute of Technology, que teve início em 1965, foi utilizado para a publicação: Urbanization Primer. Contou com a colaboração de Horacio Caminos, John F. C. Turner e John A. Steffian e é destinado às questões específicas de urbanização, de parcelamento do solo e provisão de serviços para os setores mais carentes das populações dessas cidades, através da discussão de parâmetros de tomadas de decisão em projetos, entre outros.

Ele tem por objetivo fornecer referências para a avaliação de um projeto em termos de graus de eficiência de suas partes, seus índices negativos e positivos, e conseqüentemente seus custos

Os autores orientam a que o processo se desenvolva de forma circular.

"As quantidades das avaliações físicas dos planos urbanos desenvolvidos aqui (nos estágios iniciais) podem ser úteis se algumas noções elementares forem entendidas:

a) Os custos dos serviços públicos dependem primeiramente do nível de serviços adotados e da otimização dos projetos que forneçam esses serviços; 


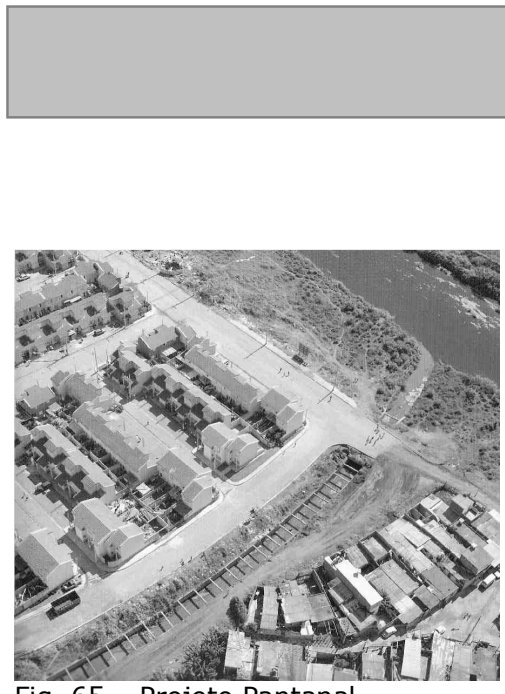

Fig. 65 - Projeto Pantanal -

Urbanização de favela e construção de novas unidades habitacionais, 2004 - Meyer, 2004

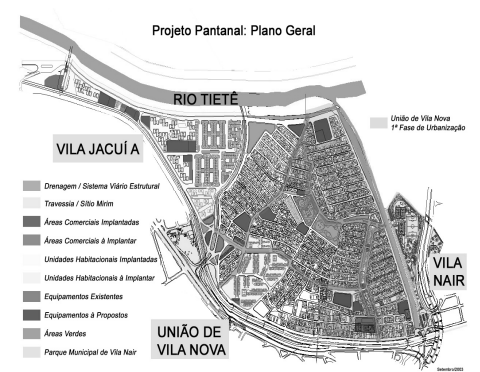

Fig. 66 - Projeto Pantanal, $2004-$ CDHU, 2004
A otimização do projeto dos serviços públicos depende primeiramente dos seus planos;

c) A otimização dos planos dos serviços públicos depende primeiramente da otimização dos planos urbanos;

d) A otimização dos planos urbanos depende primeiramente de uma porcentagem ótima do uso do solo e unidades de trechos de circulação;

e) Sempre existem planos urbanos ótimos para uma dada demanda social e econômica.

Essas condições não podem ser ignoradas, significando que um plano urbano ineficientes implicará num plano de serviços públicos ineficiente, que implicará num projeto de serviços públicos ineficientes que vai resultar num custo maior de capital e manutenção e que ainda levará a um serviço pobre à comunidade, independente das necessidades sociais e econômicas.

Esta claro que um plano urbano eficiente não vai garantir que todas as necessidades sociais e econômicas da comunidade vão ser atendidas. Mas por outro lado, fica também claro que se o plano não for otimizado, a comunidade vai ser duramente penalizada." (CAMINOS e GOETHERT, 1976 p. 8)

Segundo os autores, um dos erros mais freqüentes é o uso desnecessário de terras com sistema viário público, que ocupada áreas que poderiam ser utilizadas com outros usos, aumenta áreas pavimentadas, distâncias, impostos para usuários, entre outros.

Nesse estudo, algumas conclusões sobre os custos de infraestrutura a que se chegam podem poupar tempo de experimentação e recursos nos projetos de urbanização, a partir da análise dos modelos adotados:

1- duas avaliações devem ser feitas nos primeiros estudos: a) o custo básico das redes de serviços públicos instalados em área pública; o custo das conexões e serviços públicos sanitários instalados em área privada; 
2- nos parcelamentos em grelha apenas lotes grandes com apartamentos sem elevador podem prover maior densidade por menor custo em infraestrutura básica. Quando essa opção não é possível há apenas a alternativa de casas em pequenos lotes com maiores custos na infraestrutura básica:

3- nos parcelamentos em grelha, vários tipos combinações de lotes e residências podem prover maiores densidades e menores custos de infraestrutura básica;

4- para minimizar custos pode-se: a) abaixar o nível de prestação dos serviços públicos, o que é uma decisão política; b) otimizar o plano para um referido nível, que é uma decisão de projeto.

5- os custos são diminuídos por um plano urbano ótimo que provê, no uso do solo, áreas apropriadas de usos e trechos de circulação.

6- os custos são diminuídos por um projeto eficiente dos serviços públicos, de modo geral, e por uma distribuição de sua infraestrutura básica e conexão entre os serviços;

7- os custos podem ser diminuídos no início do processo e não no final, começando pela formulação conjugada das políticas públicas, programas e projetos comparativos;

8- os maiores custos são circulação e macrodrenagem, itens que devem ser bem avaliados desde de início;

9- os custos aumentam na seguinte escala: eletricidade/iluminação pública - insignificante; rede de água e rede de esgoto: apreciável; circulação/macro-drenagem: substancial. 
10- A aplicação de tecnologias de mão-de-obra intensiva se torna significante no casos da circulação e da macrodrenagem porque possuem o maior custo de mão-de-obra e em geral não demandam aptidões profissionais especiais

11- Circulação e Macro-drenagem podem determinar economias consideráveis, reduzindo-se quantidades de material e mão-de-obra;

12- Eletricidade/Iluminação pública podem prover pouca economia porque o auto custo do material, mesmo que otimizado o projeto, não é resultado do uso em grandes quantidades, como na Circulação, mas especialmente pelo custo do material em si;

13- Não há diferenças substanciais entre os custos de quatro alternativas de urbanização consideradas no estudo. Em compensação, a seleção da alternativa é uma decisão onde a questão do custo torna-se secundária quando confrontada com as demandas sociais, técnicas e políticas.

14- Ao contrário, a diferença substancial está no custo dos diferentes modelos. A seleção do modelo, sim, determina o custo, mas nesse caso, a escolha é limitada. (CAMINOS e GOETHERT, 1976 p.9)

O início do processo de projeto de urbanização, seja ele novos projetos ou projetos em assentamentos existentes, requer certo conhecimento para que as escolhas certas sejam feitas em função das demandas apresentadas, que por vezes são contraditórias entre si e mesmo excludentes.

A avaliação do projeto, ainda na fase de elaboração, requer alguns procedimentos iniciais onde diversas variáveis são abordadas. 
Caminos e Goethert (1976) propõem uma metodologia de avaliação do projeto que consiste em:

$$
1 \text { - Linha de identificação }
$$

a) dados do programa

b) dados do terreno ou gleba

c) dados do projeto

d) dados de custo.

2 - Padrões de execução

Com os mesmos itens do tópico acima, os autores determinam alguns padrões alcançados através de diversas experiências. Esses padrões mínimos devem ser estabelecidos de forma criteriosa.

Alguns itens merecem ser mencionados:

Porcentagem de áreas para densidade de até 600hb/ha e áreas de 1 a 100ha.

- áreas públicas:30\% máximo; 20\% desejável

- áreas privadas e semiprivadas: 55\% máximo e 60\% desejável

- áreas semipúblicas: 15\% para áreas pequenas; 20\% para áreas grandes

- circulação - unidade de distância por hectare: 150m/ha desejável; 230m/ha máximo.

3- Padrões para avaliação

Os autores propõem a avaliação em três blocos.

O primeiro, o plano urbano, em que ressaltam: 


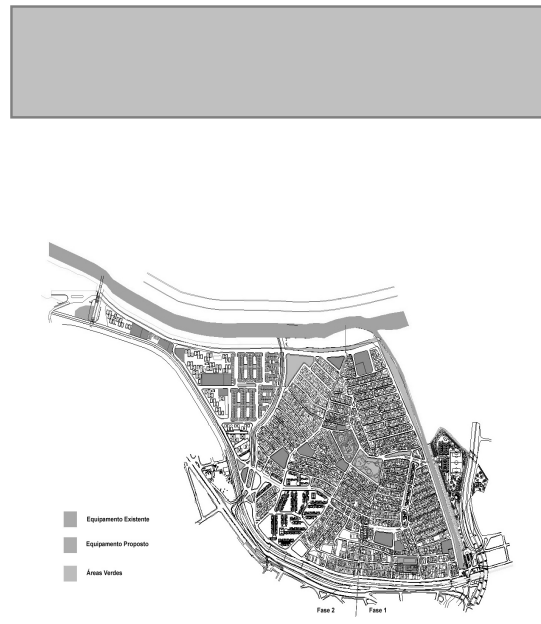

Fig. 67 - Projeto Pantanal Urbanização de favela e construção de novas unidades habitacionais CDHU, 2004

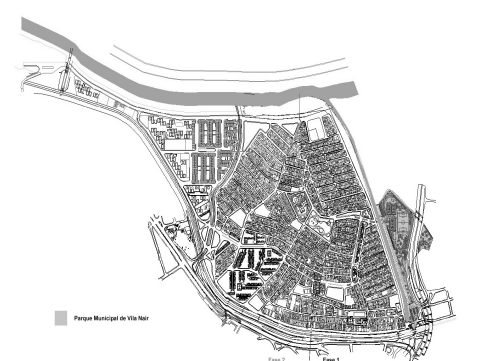

Fig. 68 - Projeto Pantanal Urbanização de favela e construção de novas unidades habitacionais CDHU, 2004 a) minimizar os custos públicos com o solo, a construção a manutenção e a operação das ruas e seus serviços;

b) aumentar as iniciativas, responsabilidades e participação da comunidade no uso da terra.

Essa primeira análise avalia aos diferentes usos distâncias totais da circulação pública.

Para o uso habitacional esse item é de suma importância à medida que a circulação pública implica na apropriação do espaço pelos moradores desde a escala do pedestre à escala do automóvel ou meios públicos de transporte.

O segundo, o plano dos serviços públicos: redes de infraestrutura básica e equipamentos

a) melhorar a eficiência em termos de construção, manutenção e operação dos sistemas;

b) minimizar os custos iniciais.

O terceiro, o custo dos serviços públicos: redes de infraestrutura básica e equipamentos

a) permitir uma distribuição equitativa de capital em termos de prioridades e custos dos serviços públicos;

b) identificar áreas de economia;

c) aumentar o investimento público em redes de infraestrutura básica reduzindo o investimento público em equipamentos individuais.

No caso das urbanizações de favelas nas regiões metropolitanas, como a de São Paulo (Projeto Pantanal, zona leste, desenvolvido pela CDHU) ou Baixada Santista (Favela México 70, desenvolvido pela $\mathrm{CDHU}$ ), por exemplo, o investimento público nessas áreas invadidas deve refletir a preocupação do Poder Público não apenas com a população residente mas também propiciar um 


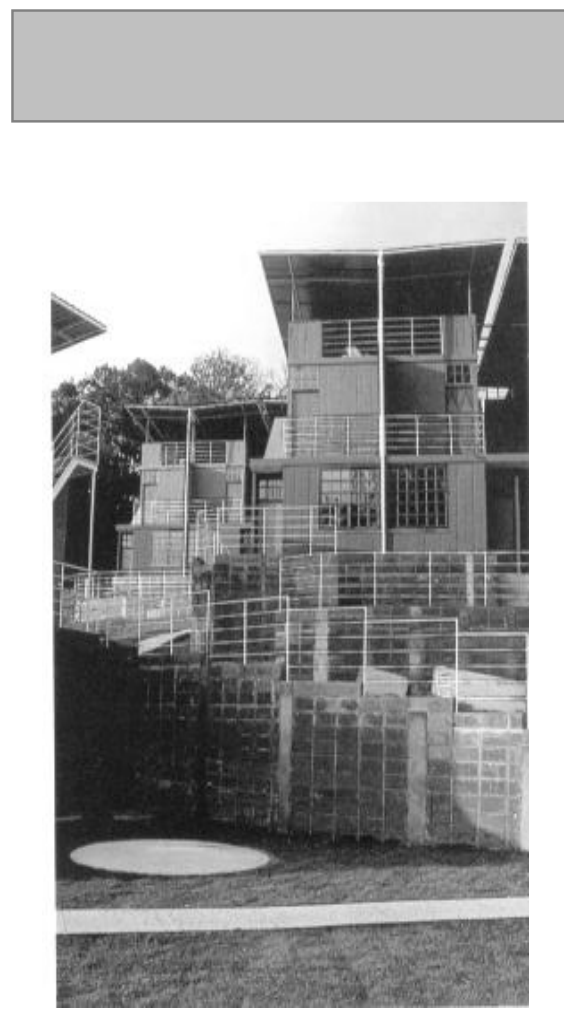

retorno em termos de qualidade urbana senão para a totalidade da cidade ou região ao menos para o entorno próximo, visto tratar-se de investimento de dinheiro público.

A avaliação da localização, dos acessos, das entradas e dos meios de transportes que servem a área é um dos fatores que possibilitarão a integração do sítio ao entorno.

Ainda primando pela qualidade espacial, a avaliação das dimensões e da forma da área de intervenção leva em consideração a densidade de pessoas/ha e pessoas/unidade habitacional (tanto como um cadastro da situação como parâmetros de projeto).

Além disso, os autores propõem a análise da topografia e características naturais; dos limites; das vistas; do solo, do clima, do regime pluviométrico; da poluição visual, sonora, etc; dos riscos de incêndio e contaminações; das zonas de restrição (aeroportos); dos equipamentos diversos; da situação fundiária; do custo da terra; da infraestrutura básica; de gás e telefone; de equipamentos de uso institucional da comunidade; de aterros sanitários; de estações de tratamento de água e esgoto; das legislações municipais, estaduais e federais de uso e ocupação do solo;da faixa de renda dos beneficiários; da densidade populacional; do sistema viário; do uso do solo; do

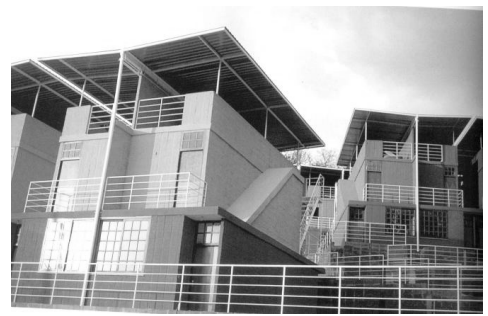

Figs. 69 e 70 - Condomínio em Cotia, SP - Juan Villà, 2003. parcelamento do solo;do plano de expansão; do diagrama básico e físico-econômico (valor comercial dos lotes).

Além da avaliação do uso do solo, dos serviços públicos e das redes de infraestrutura básicas, que são feitas no Brasil já seguindo alguns critérios, mas que deveriam ser melhor avaliados, é necessário também, nos casos de assentamentos pré-existentes, a análise das opções de moradias. 
Essa análise praticamente não acontece nos projetos públicos. A justificativa é que o Poder Público não pode intervir no espaço doméstico. Mas o caso das favelas, por tratar-se de invasões, poderia dar ao Poder Público a possibilidade de melhora ou adequação dessas moradias, se feitas de forma criteriosa e planejada.

Caminos e Goethert ilustram oito opções de moradias, descritas nos seguintes termos:

1) Programa/Produto (tipo da habitação)

2) A configuração do lote (individual ou condominial)

3) Os componentes da Unidade habitacional

4) Título de posse (proprietário ou locatário)

5) Estágio da construção (completa, reforma, ampliação, subdivisão)

6) Tipo de aquisição (compra direta, financiado pelo Estado, etc)

Estabelecem uma dimensão mínima de lote $(62 \mathrm{~m} 2)$, com uma densidade que varia de 200 hab/ha no início, a 600 hab/ha como densidade máxima.

Os autores propõem a avaliação a partir dos três blocos (plano urbano, plano dos serviços públicos e custos dos serviços públicos), utilizando os modelos propostos como parâmetros de análise em assentamentos já existentes, dimensionando as deficiências do uso do solo e da infraestrutura e sugerindo propostas de recuperação ou correção.

No Brasil a favela foi enfrentada de três formas pelo Poder Público ao longo das últimas décadas: 
"Desfavelamento, remoção ou erradicação de favelas. Esse era o discurso do BNH em seus anos inicias. Entretanto, essa proposta já havia sido tentada desde os anos 40, em diferentes cidades brasileiras, com sucesso nas áreas centrais. (...)

Aceitação da favela enquanto fenômeno urbano, mas não aceitação da forma e da tipologia urbanística e habitacional que ela revelava, levando à demolição da favela e reconstituição de tudo no mesmo lugar, com um padrão urbanístico e arquitetônico semelhante à linguagem dominante. (...)

Urbanização, ou seja, dotação de infra-estrutura, serviços e equipamentos urbanos nas favelas, mantendo-se as características do parcelamento do solo e as unidades habitacionais, postura que tem sido adotada, mais amplamente a partir do começo dos anos 80." (BUENO, 2000 p. 162)

No entanto, "a avaliação negativa sobre a transferência da população das favelas para os conjuntos em áreas periféricas foi registrado em diversos estudos ${ }^{27}$ demonstrando que grande parte dos moradores vendia a nova unidade e retornava à favela, por diferentes razões, entre elas a incapacidade econômica de pagar pela moradia, o custo sócio-econômico de morar longe do emprego e da infra-estrutura urbana e a busca de um aumento da renda, mesmo que temporário, através da venda. "(BUENO, 2000 p. 164)

A elaboração de parâmetros de projeto no Brasil para intervenção em favelas data de 1982: "... o CAPAM Centro de Estudos e Pesquisas de Administração Municipal/Fundação Faria Lima apresenta o trabalho 'Estudo de normas legais de edificação e urbanismo adequado à áreas de assentamentos subnormais ou de baixa renda.' O estudo havia sido encomendado pelo BNH para 'apresentar subsídios aos governos locais para a elaboração de normas específicas e adequadas aos projetos de recuperação e urbanização de aglomerados de subabitação(...) (BUENO, 2000 p. 192 Apud CEPAM, 1982 p. 15)

\footnotetext{
27 Ver bibliografia organizada em Valladares, 1982
} 
Esses parâmetros partiam de situações dadas nas favelas, com vielas que variavam de $2 \mathrm{~m}$ a $6 \mathrm{~m}$ e determinavam a colocação de melhorias como posteamento, fiação, etc.

Mas diversamente das orientações de Caminos e Goethert, a urbanização integrada, como passou a ser denominada a intervenção nas áreas de favelas que tinham por objetivo a integração dos domicílios às redes de infra-estrutura básica, coleta de lixo, acessos, transporte, drenagem etc, não continham parâmetros mínimos de projeto. Alguns critérios passam a ser definidos em função da elaboração e execução e manutenção de redes dos serviços públicos, que exigiam, por exemplo, vielas mínimas de $4 \mathrm{~m}$ para passagem dos caminhões de manutenção das redes e não por critérios de hierarquia viária e demandas específicas. A idéia norteadora dos projetos, no início, era a idéia do saneamento.

Bueno destaca em sua pesquisa três grandes experiências brasileiras: o Programa de Urbanização de favelas de São Paulo entre 1989 e 1992; o Programa Favela-Bairro, no Rio de Janeiro, iniciado em 1993, e ainda em andamento e o Programa de Saneamento ambiental do Reservatório Guarapiranga, com um subprograma de urbanização da favela iniciado em 1992.

As primeiras experiências em São Paulo buscavam analisar o interesse para o restante da cidade da urbanização de uma dada favela. Depois, avaliavam-se os riscos geotécnicos, e as melhorias eram implantadas em mutirão pelos moradores.

Esse tipo de intervenção, que segundo Bueno foi inspirada nas experiências realizadas na favelada Rocinha, Rio de Janeiro, foi assim caracterizada: "Urbanização simplificada: tratamento urbanístico da própria área ocupada, de modo a adaptar às próprias condições locais a implantação de serviços públicos, a construção de um sistema viário e a melhoria das habitações, com eventuais 
remanejamentos de moradias para viabilizar obras e eliminar situações de risco." (BUENO, 2000 p. 196 apud BREDARIOL 1998 p. 24)

Essa é a diretriz com que vários projetos de Urbanização Integrada foram formulados. Segundo Bueno, no Rio de Janeiro, as experiências com o favela-bairro consolida a "Urbanização Integrada como a principal política para as favelas cariocas, incorporando ações concretas de ampliação das oportunidades de melhoria das condições sócio-econômicas das favelas, através dos programas de geração de renda e emprego e de construção de equipamentos sociais dento das favelas(...)" (BUENO, 2000 p. 200)

Pelo o que se pode concluir da pesquisa de Laura Bueno, 2000, em São Paulo o processo de projeto das Urbanizações Integradas se confunde com as dificuldades das Administrações Municipais, principalmente, em viabilizarem as intervenções em favelas. Ficou um pouco por conta das empresas contratadas e na forma dos contratos como se deram esses processos.

Entre julho de 1998 e dezembro de 1999, foi desenvolvida a pesquisa "Parâmetros para urbanização de favelas", no LABHAB/FAUUSP, através da FUPAM/FAUUSP, financiada pela Finep e Caixa Econômica Federa. "A coordenação geral da pesquisa foi da proa. Ermínia Maricato. A mim coube a elaboração do projeto inicial, a coordenação técnica da pesquisa e o desenvolvimento dos aspectos relativos à qualidade ambiental das obras. A pesquisa procurou avaliar a adequabilidade, a replicabilidade e a sustentabilidade das obras de urbanização de favelas. Foram pesquisadas favelas em: Fortaleza, Goiânia, Diadema, Rio de Janeiro e São Paulo." (BUENO, 2000 p. 218)

Diferentemente da pesquisa realizada por Caminos e Goethert, a pesquisa coordenada por Maricato e Bueno primou pelo resultado urbanístico, paisagístico e ambiental, ancorado nas características socioeconômicas e em determinadas condições de vida de cidades da periferia do 
capitalismo. Portanto, não trabalhou com modelos urbanísticos experimentados e bem sucedidos, mais tarde, modelos teóricos e numéricos, mas comparou os avanços e melhoras da situação inicial dada para aquela atingida uma vez feita a intervenção.

Favelas analisadas na pesquisa "... caracterizam-se por não serem grandes favelas, ou os chamados complexos de favela do Rio de Janeiro e São Paulo, diferentes núcleos que foram crescendo e se conurbando, formando extensas áreas de ocupação densa e intrincada.": (BUENO, 2000 p. 256)

1) Castelo Encantado (Fortaleza)

Indicadores:

- 1 domicílio por lote: $86,9 \%$

- tamanho médio do lote: 90,7 m2

- área média do domicílio: 64,5m2

- m2 por morador: 13,8 m2

- número de pessoas por lote: 5,8

- número de pessoas por família: 4,9

- taxa de ocupação = 1: 16,9\%

- coeficiente de aproveitamento < 1,5: 9,2\%

\section{2) Favelas Jardim Conquista e Jardim Dom Fernando I (Goiânia)}

Jardim Conquista

- 1 domicílio por lote: 98,2\%

- tamanho médio do lote: $182 \mathrm{~m} 2$

- área média do domicílio: 51,8 m2 
- m2 por morador: $12,7 \mathrm{~m} 2$

- número de pessoas por lote: s/d

- número de pessoas por família: s/d

- taxa de ocupação > 1 : 50\%

- coeficiente de aproveitamento < 1,5: $0 \%$

Jardim Dom Fernando I

- 1 domicílio por lote: 60,7\%

- tamanho médio do lote: $228,3 \mathrm{~m} 2$

- área média do domicílio: $75 \mathrm{~m} 2$

- m2 por morador: 18 m2

- número de pessoas por lote: 5,47

- número de pessoas por família: 3,6

- taxa de ocupação > 1 : 82\%

- coeficiente de aproveitamento < 1,5: $0 \%$

3) Vila Olinda e Barão de Uruguaia (Diadema)

Vila Olímpia

- 1 domicílio por lote: $81,7 \%$

- tamanho médio do lote: $41,5 \mathrm{~m} 2$

- área média do domicílio: $51 \mathrm{~m} 2$

- m2 por morador: 13,36 m2

- número de pessoas por lote: 4,9 
- número de pessoas por família: 4,1

- taxa de ocupação = $1: 64,4 \%$

- coeficiente de aproveitamento < 1,5: 44,1\%

Barão de Uruguaia

- 1 domicílio por lote: $83 \%$

- tamanho médio do lote: $46,8 \mathrm{~m} 2$

- área média do domicílio: 63,1 m2

- m2 por morador: 16,76 m2

- número de pessoas por lote: 5,2

- número de pessoas por família: 4,3

- taxa de ocupação $=1$ : $11,1 \%$

- coeficiente de aproveitamento <1,5: 42,5\%

4) Jardim Esmeralda e Santa Lúcia (São Paulo)

Jardim Esmeralda

- 1 domicílio por lote: $78 \%$

- < 02 domicílio por lote: 0\%

- tamanho médio do lote: $54,7 \mathrm{~m} 2$

- área média do domicílio: 59,1 m2

- m2 por morador: 15,78 m2

- número de pessoas por lote: 5,1

- número de pessoas por família: 4,45 
- taxa de ocupação $=1: 62,1 \%$

- coeficiente de aproveitamento < 1,5: 27,6\%

Santa Lúcia

- 1 domicílio por lote: $68,8 \%$

- < 02 domicílio por lote: 8,4\%

- tamanho médio do lote: 73,82 m2

- área média do domicílio: 51,6 m2

- m2 por morador: 17,6 m2

- número de pessoas por lote: 5,1

- número de pessoas por família: 3,9

- taxa de ocupação = $1: 31,9 \%$

- coeficiente de aproveitamento < 1,5: 2,1\%

5) Ladeira dos Funcionários/Parque São Sebastião (Rio de Janeiro)

- 1 domicílio por lote: 63,5\%

- < 02 domicílio por lote: 14,3\%

- tamanho médio do lote: 49,4 m2

- área média do domicílio: 52,4 m2

- m2 por morador: 16,3 m2

- número de pessoas por lote: 6,3

- número de pessoas por família: 4,1

- taxa de ocupação = $1: 62,9 \%$ 


\section{- coeficiente de aproveitamento < 1,5: 42,8\%}

A pesquisa desenvolvida também analisa alguns indicadores urbanos.: densidade populacional, dimensões das favelas, sistema viário, distâncias percorridas até acesso a transporte público, uso dos espaços públicos.

1- Densidade Bruta (hab/ha)

- Santa Lúcia II (São Paulo) - 506

- Jardim Esmeralda (São Paulo) - 881

- Barão de Uruguaiana (Diadema)- 814

- Vila Olinda (Diadema) - 488

- Castelo Encantado (Fortaleza) - 370

- Jd. Conquista (Goiânia) - 89

- Jd. Dom Fernando (Goiânia) - 150

- Ladeira dos Funcionários/Parque São Sebastião (Rio de Janeiro) - 881

2 - Sistema viário

"A exceção de Goiânia, onde a largura das vias está de acordo com a legislação municipal e todas as ruas têm largura de nove metros ou superior, em todas as outras favelas foram adotados parâmetros de largura viária não convencionais - largura mínima de 1,5m, vias exclusivas para pedestres, trechos em rampa e escadaria. Entretanto, somente no Rio de Janeiro foram encontradas larguras de vielas inferiores a 1,5 metros." (BUENO, 2000 p. 256) 


\begin{tabular}{|c|c|c|c|c|}
\hline \multicolumn{5}{|c|}{3 - Dimensões das favelas } \\
\hline & Área (m2) & $\begin{array}{c}\text { Vielas }>1,5 \mathrm{~m} \text { de } \\
\text { largura }\end{array}$ & $\begin{array}{l}\text { Comprimento } \\
\text { das vielas }(\mathbf{m})\end{array}$ & $\begin{array}{l}\text { Distância máxima da casa à via } \\
\text { carroçável (> 3m largura) (m) }\end{array}$ \\
\hline $\begin{array}{l}\text { - Santa Lúcia II (São Paulo) - } \\
506\end{array}$ & 10.700 & não & & 30 \\
\hline $\begin{array}{l}\text { - Jardim Esmeralda (São Paulo) } \\
\text { - } 881\end{array}$ & 15.000 & $\operatorname{sim}$ & 15 & 10 \\
\hline $\begin{array}{l}\text { - Barão de Uruguaiana } \\
\text { (Diadema)- } 814\end{array}$ & 7.900 & $\operatorname{sim}$ & 15 & 40 \\
\hline - Vila Olinda (Diadema) - 488 & 47.500 & não & & 45 \\
\hline $\begin{array}{l}\text { - Castelo Encantado (Fortaleza) } \\
-370\end{array}$ & 86.000 & não & & 100 \\
\hline - Jd. Conquista (Goiânia) - 89 & 14.000 & não & & Acesso aos lotes por veículos \\
\hline $\begin{array}{l}\text { - Jd. Dom Fernando (Goiânia) - } \\
150\end{array}$ & 19.600 & não & & Acesso aos lotes por veículos \\
\hline $\begin{array}{l}\text { - Ladeira dos } \\
\text { Funcionário/Parque S. } \\
\text { Sebastião }\end{array}$ & 27.000 & $\operatorname{sim}$ & $\begin{array}{l}500 \text { (46 } \\
\text { logradouros } \\
\text { públicos) }\end{array}$ & 60 \\
\hline
\end{tabular}

Fonte: LABHAB, 1999B, tabulação in BUENO, 2000 p. 257 
4 - Moradores que ficam em casa

\begin{tabular}{|l|c|}
\hline & $\begin{array}{r}\text { \% dos moradores que ficam em casa sobre o total (donas de } \\
\text { casa, crianças < 16 anos, desocupados, deficientes, } \\
\text { desempregados e aposentados) }\end{array}$ \\
\hline - Santa Lúcia II (São Paulo) - & 70,1 \\
\hline $\begin{array}{l}\text { - Jardim Esmeralda (São Paulo) } \\
\text { - 881 }\end{array}$ & 68,02 \\
\hline - Barão de Uruguaiana & 70 \\
\hline (Diadema)- 814 & 71,9 \\
\hline - Vila Olinda (Diadema) - 488 & 67,9 \\
\hline - Castelo Encantado (Fortaleza) & 76,07 \\
\hline - 370 & 65,07 \\
\hline - Jd. Conquista (Goiânia) - 89 & 62,3 \\
\hline - Jd. Dom Fernando (Goiânia) - & \\
\hline 150 & \\
\hline - Ladeira dos & \\
\hline Funcionários/Parque S. & \\
\hline Sebastião & \\
\hline
\end{tabular}

Fonte: Almeida e Bueno, 1999:22 in BUENO, 2000 p. 257 
Esses dados sobre os moradores que ficam em casa dizem respeito principalmente ao tempo em que há um grande número de pessoas durante o dia nas favelas.

"Um dos aspectos controvertidos em relação aos espaços urbanizados de favela refere-se à construção e uso dos espaços públicos coletivos. O panorama geral aparece da seguinte forma: quanto à apropriação da área e respectivos comportamentos do morador: o espaço público depredado; a rua, semiprivada, continuidade da casa, sempre repleta de moradores; e a casa, particular, espaço reservado. De acordo com os dados levantados, as respostas dos moradores sobre equipamento urbano e área de lazer, freqüentemente, indicam que: ou a população (ou parte dela) depreda o mobiliário urbano, como no Castelo Encantado; ou ele não chega a ser construído, como na Santa Lúcia; ou não chegam a ser identificados como tal, como no Jardim Esmeralda; ou os espaços reservados para lazer são monótonos e sem graça, como é o caso das áreas destinadas ao lazer no projeto das posses de Goiânia (e que estão sendo pouco a pouco ocupadas pelos equipamentos comunitários como colégio, igreja, centro comunitário)" ([citando) Almeida e Bueno, 1999:22) (BUENO, 2000 p. 258)

A pesquisa de Bueno continua em uma análise dos serviços públicos implementados e dos efeitos multiplicadores da intervenção, como melhora das moradias através de reformas pelos próprios moradores - Santa Lúcia II 50\%; Jd. Esmeralda 39\%; Barão de Uruguaiana 61,3\%; Vila Olinda 66.7\%; Castelo Encantado 33.9\%; Jd. Conquista 25,5\%; Jd. Dom Fernando 55,8\%; Ladeira dos Funcionário/Parque S. Sebastião 36,7\% e integração e participação da população.

A pesquisa de Bueno destaca principalmente a complexidade da intervenção em favelas, apresentando alguns indicadores urbanísticos, sem aprofundar-se nas questões teóricas de cada um deles como uma contribuição concreta para o processo de projeto em Urbanizações de favelas. Isso não invalida de forma alguma a importância de seu trabalho como contribuição para o 
processo de projeto, mas não abarca questões específicas de qualidade de projeto de qualidade de espaço e parâmetros aplicáveis de forma confiável.

O fato das favelas escolhidas para a pesquisa serem pequenas reduziu o número de variáveis da questão. Mas as recomendações e conclusões da pesquisa são válidas enquanto contribuição para o processo de projeto:

" As experiências analisadas demonstram que a implementação de projetos de urbanização de favelas é complexa e demorada, exigindo grande determinação do órgão executor ou promotor em finalizar as obras. Alguns dos programas, como o de São Paulo, sofreram interrupções em função de mudanças nas administrações municipal e estadual.

A integração na concepção dos projetos parece ser um fator determinante na avaliação positiva de sua sustentabilidade e adequabilidade. Quando os estudos de urbanismo, as decisões sobre relocações etc. são feitas em conjunto com saneamento, em especial água, esgoto e drenagem, as soluções apresentam-se mais eficientes. Há casos em que também os serviços de coleta de lixo foram considerados de forma integrada.

(...)

... destaco algumas das principais recomendações do relatório final da pesquisa:

'[...] ]as obras de urbanização não devem ser intervenções pontuais, mas integrar-se nos projetos de um conjunto de intervenções nos bairros [...]'

'O escopo dos projetos de urbanização deve ser abrangente e desenvolvido de forma integrada, possibilitando a melhor adequação das soluções técnicas desenvolvidas pelos profissionais das diferentes especialidades. '

[...] devem ser implementados programas de assessoria técnica para a execução de adaptações das instalações hidráulicas e elétricas das moradias[...] p.9 
'O mesmo deve ser assumido para as obras de ampliação ou melhoria das habitações[..]'

'Devem ser criados sistemas de fiscalização do uso do solo e ocupação do solo após as obras [...]'

'As políticas de serviços municipais e das concessionárias devem considerar as favelas, espaços construídos com outros padrões. Esses ambientes exigem parâmetros eventualmente 'formatos' de serviços diferenciados. Esse fator deve ser considerado com bastante cuidado no caso da privatização destes serviços.' P.10 
O processo de projeto de urbanização de favelas é apenas uma das partes de um vasto programa para a intervenção em favela.

Aprofundar-se nesse tema para efeito de um trabalho científico, como uma dissertação, implica em selecionar alguns aspectos em detrimento de outros.

A necessidade de se compreenderem os complexos fenômenos sociais faz dos estudos de caso bons instrumentos de pesquisa, utilizados por Bueno e Valladares, principalmente. "O estudo de caso permite uma investigação para se preservar as características holísticas e significativas dos acontecimentos da vida real - tais como ciclos de vida individuais, processos organizacionais e administrativos, mudanças ocorridas em regiões urbanas, relações internacionais e a maturação de setores econômicos." (YIN, 2005 p.20)

Para a elaboração de uma teoria sobre o processo de projeto de urbanização de favelas é necessário um aprofundamento de metodologias. A aplicação dessas metodologias vai se fazendo paulatinamente com a contribuição de diversos pesquisadores em diversos campos do conhecimento.

A sistematização dos dados referentes às intervenções de algumas favelas no Brasil feita por Bueno somada às recomendações de Caminos explicitam como ainda é necessário o estudo e aprofundamento dos parâmetros de projeto para urbanização de favelas.

Uma vez que a favela passa a ser parte do cenário urbano não apenas como paisagem, mas também como estrutura (através da implementação de infra-estrutura básica, eletricidade, e possível regularização fundiária) o estudo desses parâmetros deve levar em consideração fatores de adaptabilidade futura. Se a intenção é inserir não apenas a população na cidade, como também 
conectar o espaço físico que ela ocupa ao restante da cidade, os parâmetros de projeto nesses assentamentos existentes devem sim ser específicos, mas devem levar a uma qualidade urbana similar à média da cidade onde se insere, sem desprezar a dinâmica urbana de uma dada comunidade.

A viabilidade das intervenções em favelas para a população deveriam passar por outras análises que não apenas a do menor custo para o morador ou para o poder público. O foco do administrador público, e não do arquiteto projetista, deve ser o de racionalizar os custos gerais da intervenção através da otimização dos recursos empregados ainda na fase de projeto. E além disso, de forma integrada com as diversas instâncias governamentais (Secretaria do Trabalho, do Esporte, do Turismo, da Indústria e Comércio) ampliar o Programa de Intervenção Urbana na Área de favela para atividades de inserção econômica e geração de renda, e/ou alternativas para o acesso à moradia como a figura da locação social.

Por toda essa complexidade, cabe ainda ao arquiteto projetista aprofundar-se naquilo que Ihe compete: detalhar os processos de projeto de urbanização de favelas para que os objetivos gerais do programa de intervenção sejam alcançados. Do ponto de vista da metodologia de projetos de arquitetura e urbanismo, esse detalhamento deverá caminhar paralelamente a pesquisas no campo de Projeto, alinhado com revisões como a da pesquisa ARQUITETURA E CIÊNCIA: VISÕES PARALELAS DO MUNDO CONTEMPORÂNEO. CAMINHOS PARA UM MODELO TEÓRICO APLICÁVEL NO PROCESSO DE PROJETO, de Rosamônica da Fonseca LAMOUNIER, (MESTRADO/ EAUFMG/ CAPES), sob orientação de José dos Santos CABRAL FILHO (UFMG) 
O Estudo de Caso que segue (Projeto de Urbanização da Favela México 70) visa contribuir para o desenvolvimento dessas discussões. 


\section{Capítulo IV}

\section{Urbanização de favelas: políticas públicas e seus projetos}


Tendo como objetivo iniciar investigações sobre o processo de projetos de urbanização de favelas, a pesquisa como um todo se caracteriza por utilizar a Metodologia Qualitativa, que se preocupa em "analisar e interpretar aspectos mais profundos, descrevendo a complexidade do comportamento humano. Fornece análise mais detalhada sobre as investigações, hábitos, atitudes, tendências de comportamento etc." (MARCONI e LAKATOS, 2005 p. 269)

Essa metodologia foi escolhida porque "é o que se desenvolve numa situação natural; é rico em dados descritivos, tem um plano aberto e flexível e focaliza a realidade de forma complexa e contextualizada" (MARCONI e LAKATOS, 2005 p. 271 apud MENGA, 2002: 21-22)

Nesse tipo de pesquisa há um mínimo de estruturação prévia. "Não se admitem regras precisas, como problemas, hipóteses e variáveis antecipadas, e as teorias aplicáveis deverão ser empregadas no decorrer da investigação.

Alvez e Mazzotti (1999:158) admitem que a 'adoção prévia de um quadro teórico, a priori, turva a visão do pesquisador, levando-o a desconsiderar aspectos importantes, que não se encaixam na teoria e a fazer interpretações distorcidas dos fenômenos estudados'". (MARCONI e LAKATOS, 2005 p. 271)

Tanto o projeto profissional de urbanização, apresentado a seguir, como a pesquisa que deu origem a esta dissertação tiveram a mesma origem: o estudo de caso da Favela México 70. Essa escolha se deu pelo fato de poder-se, através do levantamento de dados na favela para elaboração do projeto de urbanização, alcançar maior profundidade em vários aspectos do projeto.

O uso de Estudo de Caso, para Ludke e André (1986:18-20) apresenta algumas características fundamentais:

a) visa a descoberta;

b) enfatiza a interpretação do contexto; 
c) retrata a realidade de forma ampla;

d) vale-se de fontes diversas de informações;

e) permite substituições;

f) representa diferentes pontos de vista em dada situação;

g) usa linguagem simples.

Dessa forma, nos primeiros capítulos a intenção era, através de análise histórica, caracterizar a dinâmica de produção de habitação nas sucessivas periferias na cidade de São Paulo.

Uma vez ampliado o entendimento dessa dinâmica, elencou-se a favela como objeto de estudo para intervenções urbanas. O capítulo anterior e o presente procuram, então, caracterizar a favela enquanto fenômeno urbano, as modalidades de intervenção pública nas favelas e os processos de projeto de urbanização de favelas em prática e em desenvolvimento.

Considerar os assentamentos informais como provisão habitacional, por outro lado, vai de encontro aos conceitos definidos por Maricato e Ball, descritos no posfácio de Ermínia Maricato em Davis (2006):"Michael Ball desenvolveu o conceito de formas de provisão de habitação, buscando melhor compreender a produção do ambiente construído ou, mais exatamente, a estrutura de provisão de moradias, em cada momento histórico, de determinada sociedade, por meio do conhecimento dos agentes que delas participam e das regras que a regulam. ${ }^{28}$ Diferentes capitais (financiamento, construção e promoção imobiliária), proprietários de terra ou imóveis, trabalhadores da construção estão entre os principais agentes que disputam lucros, juros, rendas e salários pelo papel do Estado que regula o mercado,

${ }^{28}$ M. Ball, "Housing analysis: time for a theorical refocus", Housing Studies, Londres, v.1, n.3, 1986 
a terra, o financiamento e a força de trabalho. Cada forma de provisão de moradia implica diferentes formas de arranjo desses agentes: condomínios de casas unifamiliares, incorporação privada de apartamentos para a venda ou para aluguel, promoção pública para aluguel ou venda. Implica também diferentes formas de posse (tenure). A legislação urbana, a regulação do financiamento (com a decisão sobre a quantidade de subsídios a serem investidos), o próprio estágio de luta dos trabalhadores são exemplos de fatores que interferem na produtividade e nos resultados que conformam parte do ambiente construído. Ball trabalhou sobre o quadro da produção capitalista central, mas, tomando o devido cuidado, podemos fazer uso de seus conceitos para incorporar às formas de provisão capitalista da moradia os chamados assentamentos informais que, embora não constituam formas capitalistas stricto sensu, contribuem para o processo de acumulação ao reduzir o preço de reprodução da forma de trabalho." (DAVIS, 2006 p. 221-222)

Com isso a finalização da pesquisa não é conclusiva, mas ao contrário, pretende iniciar uma série de indagações na área de processos de projeto de arquitetura e urbanismo, com foco na questão das urbanizações de favelas, incitando novas pesquisas. 
A informalidade acompanhava de perto o fenômeno de periferização das habitações em São

Paulo. Além das habitações operárias e populares ${ }^{29}$, a periferia passou a receber favelas.

"No início do século XX, as intervenções sanitárias seguidas por demolições de cortiços constituíram um mecanismo de expulsão da população de áreas centrais. Um dos casos mais importantes no Brasil é o da remodelação urbanística (Reforma de Passos) no Rio de Janeiro, no começo do século $X X$, realizada pelo engenheiro Francisco Pereira Passos (1902-1906), quando foram destruídos milhares de domicílios. A expulsão levou parcelas dessa população a invadir os morros e constituir as favelas." (DENALDI, 2003, p. 10)

"No início do século XX, o Governo Republicano estimula os setores privados a construírem Vilas Operárias. O governo intervém regulamentando (Decreto n. ${ }^{\circ} 01$ de 1892) e incentivando, por meio da isenção de impostos, essa modalidade de produção habitacional [...]. No período Vargas (19301945), a atuação governamental ocorre tanto no controle dos valores de locação, como na produção habitacional, por meio das carteiras prediais dos Institutos de Aposentadoria e Pensões (IAPS).

Os IAPs passam a aplicar parcela de seus recursos na construção de moradias para seus associados. Sua produção foi expressiva, chegando em 1945 a atender cerca de 5,2\% da população urbana brasileira - estimada em 14,31 milhões - com a produção de cerca de 124.000 unidades habitacionais num período de 8 anos - de 1937 a 1945 [...]. Embora a produção tenha sido expressiva, seu atendimento era restrito à população ligada à indústria, deixando sem atendimento grande parcela da população." (DENALDI, 2003, p. 12)

Com a Lei do Inquilinato em 1942, que congelava o valor dos aluguéis, a crise habitacional tendeu a aumentar, já que grande parte da população usava o aluguel como forma de moradia

\footnotetext{
${ }^{29}$ Sobre as habitações populares, operárias e residenciais ver TP2, Memorial de Qualificação, VIOLA, 2008.
} 
(BONDUKI, 1998, p. 43). "[...] num período de 27 anos, entre 1937 e 1964, excluindo-se os financiamentos de classe média, os IAPS (Institutos de Aposentadoria e Pensão) e pela FCP (Fundação da Casa Popular) produziram cerca de 143 mil unidades habitacionais, uma média de 5,3 mil por ano" (BONDUKI, 1998, p. 129). Esses números indicam uma situação favorável à atuação do Estado, tendo sido atingidos cerca de $10 \%$ da população que vivia em cidades com mais de 50 mil habitantes (BONDUKI, 1998, p. 128).

Em 1964, foi criado o BNH (Banco Nacional de Habitação), sob o regime militar, para financiar obras de saneamento básico e urbano, habitação e projetos na área de transporte e energia.

"O BNH foi criado sobre uma contradição insolúvel: atender prioritariamente, com a produção de moradias, a população de baixa renda, e ser lucrativo e auto-sustentável financeiramente, supondo que essa população poderia pagar pela casa própria não subsidiada [grifo nosso] ${ }^{30}$. O balanço final de sua atuação mostra que a maior parte de sua produção habitacional foi destinada aos setores de renda média." (DENALDI, 2003, p. 14)

Na década de 1970, dois programas federais se voltavam especificamente à questão das favelas. Lançado em 1975, o PROFILURB tinha como objetivo a criação de lotes urbanizados com embriões habitacionais para famílias de 0 a 3 salários mínimos, sempre financiados (cerca de 43.000 lotes no país até o final dos anos 1980). O outro programa era o PROMORAR, de 1979, "que admitiu consolidar a ocupação (favela). O programa viabilizava a manutenção da população no local,

${ }^{30}$ A construção de moradias pelo Estado, a urbanização de favelas e a oferta de lotes urbanizados requerem pagamento direto dos moradores. O subsídio na área habitacional não é posto em prática - um demérito não só do BNH, mas também do Banco Mundial. No Brasil, até o final dos anos 1990, nenhuma orientação política promoveu esse subsídio. 
mediante financiamento para substituição do barraco por casas de alvenaria e para a execução de infraestrutura urbana. O programa financiava até 300 UPCs para construção de unidades-embriões de até $25 \mathrm{~m}^{2}$. 'O programa executado por empresas construtoras financiou 206.000 unidades em todo Brasil até 1984'." (DENALDI, 2003, p. 16 Appud Bueno, 1998)

As favelas, diferentemente dos loteamentos autoconstruídos, são invasões em áreas geralmente públicas, ou seja, nelas não há preço inicial da terra (terras gratuitas). Desde os anos 1990, tem sido principalmente consideradas pelas esferas oficiais como "ocupações informais".

O IBGE as define como "unidades domiciliares, construídas de madeira, zinco, lata, papelão e até alvenaria, distribuídas desordenadamente em terrenos cuja propriedade individual do lote não é legalizada para aqueles que os ocupam, sendo que na maioria das vezes ocupam áreas com declividade acentuada ou inundável" (IBGE, apud ABIKO, 2005). Tal definição não revela, porém, que com o passar do tempo os moradores investem em suas moradias e, com essa melhoria, mudando em certo grau o caráter dessas favelas (ABIKO, 2005).

Além das deficiências físicas que têm caracterizado esse agrupamento (moradias precárias, falta de infra-estrutura básica e de equipamentos e serviços comunitários), há ainda as questões fundiárias a serem resolvidas. O crescimento das favelas apresenta-se como uma tendência de expansão urbana, não só intensificando dificuldades no conjunto da cidade, mas também explicitando espacialmente as diferenças sociais.

A partir de 1970, no Brasil, a União, os estados e os municípios passavam a encarar essa realidade de outra forma: "Das tentativas de erradicação das favelas passou-se a privilegiar a urbanização das áreas cuja ocupação já estava consolidada" (LARANGEIRA, 2005). 
O BNH, no âmbito do Plano Nacional de Habitação Popular (PLANHAP), proporcionava empréstimos para a produção de lotes urbanizados e aquisição de materiais de construção. Em 1979, o PROMORAR foi criado para financiar projetos de urbanização de favelas (LARANGEIRA, 2005, p. 11).

Com o fechamento do BNH em 1986, o governo federal deixava de ter como prioridade a urbanização das favelas, ainda que os municípios e estados continuassem a atuar nessa área.

O crescimento de favelas e o surgimento de novas não parecem constituir um fenômeno que esteja próximo de desaparecer. Ao contrário. O desenvolvimento econômico nas grandes cidades tende a aumentar as desigualdades sociais, resultando em expansão de favelas como forma de solução habitacional.

"O caráter dual e ambíguo das cidades em relação ao emprego tem sido reconhecido pela Organização Internacional do Trabalho [OIT]. Ao ressaltar o paradoxo entre os papéis da cidade como 'máquina de desenvolvimento econômico' e como 'centros de desemprego urbano' [...], a OIT [...] aponta para a incapacidade de o setor privado reproduzir-se na velocidade necessária para oferecer emprego às populações que afluíram às cidades no ciclo da industrialização, com isso ampliando a economia informal. Destaca para o fato de, mais recentemente, a inovação tecnológica em produção e comunicação contribuir para este paradoxo, ao promover simultaneamente crescimento econômico e aumento de desemprego." (SILVA, apud AMARAL, 2005)

Por outro lado, como característica interna da sociedade brasileira, segundo Ermínia Maricato, em posfácio de Davis (2006): "Não se pode responsabilizar a globalização e as políticas neoliberais pela segregação e pela pobreza que são estruturais em um país cuja esfera social é profundamente desigual. [...] O IBGE mostra que enquanto a população brasileira cresceu a 1,9\% ao ano 
entre 1980 e 1991, e 1,6\% entre 1991 e 2000, a população favelada cresceu respectivamente 7,65\% e 4,18\%. Em 1970, a cidade de São Paulo tinha apenas 1,2\% da população morando em favelas, segundo dados da Secretaria de Habitação e Desenvolvimento Urbano da Prefeitura Municipal (Sehab). Em 2005, essa proporção sobe para $11 \%$ segundo a mesma fonte. (DAVIS, 2006 p. 215)

As favelas não apenas representam uma realidade, como prometem continuar a sê-lo por bom tempo. Para nelas se intervir, requerem-se processos de projeto que levem em conta sua perenidade (em vez de considerá-las como alojamentos provisórios), em coerência, portanto com a lógica da expansão das áreas de especulação imobiliária.

A partir dos anos 1990, as questões ambientais passaram a fazer parte do arcabouço de preocupações jurídicas e institucionais, alterando o enfoque dado à urbanização de favelas, geralmente situadas em áreas ambientalmente frágeis.

Como se viu no Capítulo III, algumas opiniões como a de Bueno (2000) e mesmo de Caminos, (1976) quanto a manutenção da população favelada em seu local de origem, com intervenção do Estado na recuperação urbana abrem um leque de possibilidades de trabalho profissional na área de projeto de arquitetura e urbanismo.

Davis (2006), no entanto, elabora severas críticas ao modelo preconizado por John Turner.

Segundo ele, o Banco Mundial passava a ter grande influência não apenas sobre governos do Terceiro Mundo, mas também sobre Organizações Não-Governamentais (ONGs) e comunidades faveladas locais.

Um encontro de dois intelectuais levaria ao surgimento e disseminação da idéia de manter as favelas, urbanizando-as e legalizando-as. 
Para John Turner, arquiteto inglês defensor da oferta de lotes urbanizados (atendidos por infra-estrutura de água, esgoto e obras de engenharia), caberia ao morador da favela a inteira responsabilidade sobre a construção de moradia com vistas à futura legalização. Robert McNamara, presidente do Banco Mundial nos anos 1970, via nessa solução uma abordagem pragmática e de baixo custo para a crise urbana das grandes cidades do Terceiro Mundo (DAVIS, 2006).

A idéia encantou muitos arquitetos mundo afora, que reconheceram a capacidade das comunidades de favelas de estabelecer um "'relacionamento orgânico' entre construções $e$ terreno" e viram com entusiasmo "a flexibilidade dos espaços para acomodar diversas funções e as necessidades variáveis dos usuários". Por outro lado, "elogiar a práxis dos pobres tornou-se uma cortina de fumaça para revogar compromissos estatais históricos de reduzir a pobreza e o déficit habitacional" (DAVIS, 2006, p. 80).

O conceito urbanístico se baseava, de um lado, no uso de lotes populares servidos de infraestrutura básica, legalizados e destinados a moradores que autoconstruiriam suas casas e, de outro, na realização de obras de saneamento básico, engenharia civil e regularização fundiária sem a remoção da comunidade local, atividades essas financiadas por empréstimos bancários a taxas muito reduzidas. Os lotes deveriam ser adquiridos pelos moradores, que, uma vez regularizada a favela, passavam a ter de respeitar as normas urbanas da cidade, incluindo o pagamento das taxas de concessionários (infra-estrutura, coleta de lixo etc.), muito embora houvesse, e não só no Brasil, zonas de interesse social em que os parâmetros urbanos eram mais tolerantes. 
Pesquisas posteriores sobre a nova ortodoxia defendida pelo Banco Mundial de fato contradisseram o argumento de que o processo levaria a uma redução de custos: "Como demonstrou a pesquisa de Kavita Datta e Gareth Jones, a perda da economia de escala na construção de casas leva a preços unitários altíssimos do material de construção [...] ou à substituição por material de segunda mão e de má qualidade" (DAVIS, 2006, p. 80). O próprio Banco Mundial estimou em 1987 que "os 30\% a 60\% mais pobres da população, dependendo do país, eram incapazes de atender às obrigações financeiras da oferta de lotes urbanizados de empréstimos para melhorias" (DAVIS, 2006, p. 81).

Essas críticas de Davis (2006) colaboram sim para que os processos de projetos de urbanização de favelas possam vir a minimizar os custos da produção habitacional, mas não são suficientes para descartar a urbanização das favelas como alternativa de atendimento habitacional de qualidade.

Ocupando uma área de $1.523 \mathrm{~km}^{2}$, São Paulo abriga 10.435 .546 habitantes, segundo o censo de 2000, dos quais 510.498 ganham até um salário mínimo, 909.290 de um a dois salários mínimo e 663.224 de dois a três e 1.054.122 de três a cinco salários mínimos. Têm-se então 1.624012 habitantes, ou $15,56 \%$ do município, que recebem até três salários mínimos e 2.678.134 (25,66\%) com até cinco. 
Para fins estatísticos, considera-se a faixa média dos moradores de favela que auferem de 0 a 5 salários mínimos. A maior parte está na faixa de 1 e 3 salários mínimos, mas por falta de oferta de moradias formais, famílias que poderiam não viver em favelas vivem nelas ${ }^{31}$.

O Banco Mundial tem sido o principal financiador das urbanizações de favelas desde a década de 1990, com participação ativa não só em análises periódicas e recomendações, mas também no processo de desenvolvimento de políticas públicas relacionadas ao assunto e de processos de projeto para o enfrentamento da questão. Segundo a arq. Elisabete França, da Secretaria Municipal de Habitação, a atuação do Banco Mundial teve o grande mérito de orientar a formulação de metodologias de intervenção nas grandes favelas metropolitanas.

${ }^{31}$ IBGE. Censo 2000. 
O processo de projetos de urbanização de favelas se encontra num contexto urbano em países como o Brasil muito diverso dos países centrais: "Nos países do terceiro mundo, como o Brasil, os novos conceitos e métodos [da arquitetura e urbanismo] são estruturados a partir de realidades bastante diferenciadas daquelas dos países centrais. A condição atual das nossas cidades se manifesta por meio da escassez, da insalubridade, do descontrole das ocupações e da baixa qualidade das moradias, em sua grande parcela autoconstruídas. Decorrente de problemas econômicos e políticos, o crescimento incessante e descontrolado das metrópoles não é acompanhado de políticas públicas capazes de atender às necessidades mais imediatas de suas populações". (BAYEUX; FRANÇA, 2002)

Em São Paulo, a mais significativa experiência em urbanização de favelas, talvez por ser a primeira desse porte, foi a despoluição da Bacia do Guarapiranga - o Programa Guarapiranga, da década de 1990, que envolveu vários projetos de reassentamento habitacional e urbanização. Ao invés de simplesmente sanear (levar água potável, fazer esgotamento sanitário e drenagem pluvial e coletar lixo), o programa interveio nas áreas a serem urbanizadas de forma a garantir maior qualidade urbana, entre outros objetivos.

Em muitos casos, os programas de urbanização de favelas resultam em padrões habitacionais de melhor qualidade do que aqueles encontrados em assentamentos informais. $O$ processo de projeto utilizado pode ser um dos determinantes desse sucesso (WERMA, 2001, apud ABIKO, 2005), opinião compartilhada pela arq. Elisabete França, da Secretaria Municipal de Habitação ${ }^{32}$.

\footnotetext{
${ }^{32}$ Entrevista concedida em 4 mar. 2008.
} 
O engenheiro Alex Kenya Abiko, livre-docente em Engenharia e Planejamento Urbano da Escola Politécnica da USP atuou em diversos organismos públicos voltados à área de habitação e coordena alguns projetos do Programa Habitare. Estudioso das questões de infra-estrutura e urbanização, Abiko analisou programas de urbanização de favelas no Brasil num estudo empreendido pela Cities Alliance e Banco Mundial que integrou a iniciativa Estudos Estratégicos de Apoio às Políticas Urbanas para os Grupos de Baixa Renda no Brasil.

O Programa Guarapiranga contou com financiamento do Banco Mundial e foi coordenado pela Unidade de Gerenciamento do Programa (UGP), ficando a execução a cargo da Prefeitura do Município de São Paulo (PMSP) da Secretaria do Meio Ambiente do Município de São Paulo (SMA), da Companhia de Desenvolvimento Habitacional e Urbano (CDHU) e da Companhia de Saneamento Básico do Estado de São Paulo (Sabesp). Os objetivos básicos do programa se relacionavam às seguintes áreas:

1. serviços de água e esgoto;

2. coleta e disposição de lixo;

3. recuperação urbana;

4. proteção ambiental;

5. gestão da bacia.

Os objetivos do programa são em linhas gerais (CAVALLIERI, 2003, apud ABIKO, 2005):

1. Dotar as favelas de infra-estrutura básica - abastecimento de água, esgotamento sanitário, drenagem pluvial, coleta de lixo, limpeza pública, contenção de encostas, iluminação pública, 
reflorestamento e arborização, de modo que se mantenha uma boa qualidade de operação dos sistemas pelas concessionárias.

2. Estabelecer integração com o entorno, principalmente através do sistema viário, com a abertura de algumas vias com leito carroçável. Internamente, a reorganização espacial se daria com a implantação de sistemas de áreas livres - quadras, parques e praças.

3. Prestar serviços sociais à comunidade, inicialmente com a implantação de creches e programas junto aos jovens para afastá-los do tráfico de drogas.

4. Regularizar, do ponto de vista legal, as propriedades públicas e privadas. Segundo Cavallieri (2003), a titulação das propriedades não foi alcançada, mas foram implantadas áreas de interesse social.

O custo por família na implantação do programa é de extrema importância aos olhos do Banco Mundial, financiador do programa. A eficiência do sistema deve ser a maior possível dentro do orçamento estimado, requerendo-se para isso desenvolver tecnologia que barateie 0 desenvolvimento e implementação do projeto. 


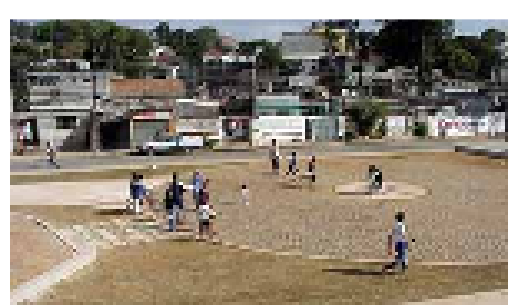

Fig. 71 - Jardim Imbuias,

Guarapiranga, São Paulo. Vista depois da intervenção. Arquiteto Paulo Bastos, 2008
A recuperação ambiental foi uma das grandes forças motrizes que orientou o poder público na realização de grandes projetos de urbanização de favelas nas regiões metropolitanas no Brasil a partir dos anos 1990, uma vez que as favelas, por se situarem em geral em áreas ambientalmente frágeis, tinham grande impacto ambiental.

"[No Brasil,] ao longo da década de 1990, por força do novo quadro jurídico e institucional que passa a reger as políticas e ações de proteção ambiental, a questão das favelas ganha outros contornos, pois, via de regra, ocupam áreas de risco ambiental ou protegidas pela legislação federal e estadual. Neste período têm início os programas de despoluição de bacias hidrográficas, intervenções de grande porte, contando com recursos nacionais de contrapartida e empréstimos externos do Banco Mundial e do Banco Interamericano de Desenvolvimento - BID. Muitos desses programas incluem investimentos destinados a resolver os problemas dos assentamentos ilegais, através de remanejamento e reassentamento das famílias ou de urbanização, quando possível. O Programa de Despoluição da Bacia do Guarapiranga em São Paulo e o de Despoluição da Baía de Todos os Santos em Salvador, ambos financiados pelo Banco Mundial, são exemplos dos mais importantes nessa direção." (LARANGEIRA, 2005)

O Programa Guarapiranga foi precursor, inaugurando uma metodologia de intervenção em favelas. Assim, como este, o Programa de Despoluição da Bacia de Todos os Santos, em Salvador, tinha então como objetivos principais (CAVALLIERI, 2003 apud ABIKO, 2005, p. 15):

a) dotar as favelas de saneamento básico de boa qualidade, de funcionamento adequado e com manutenção oficial dos órgãos públicos: obras destinadas a permitir a implantação, operação e manutenção dos equipamentos e serviços de abastecimento de água, esgotamento sanitário, 
drenagem pluvial, coleta de lixo, limpeza pública, contenção de encostas, iluminação pública, reflorestamento e arborização;

b) promover uma reorganização espacial das favelas pela integração viária com a malha urbana circundante e implantação de espaços de uso coletivo: integração da favela com a malha viária, implantando-se uma ou mais vias carroçáveis e espaços para a prática de esportes, praças e parques;

c) prestar serviços sociais dirigidos a atender aos vários segmentos da população de baixa renda: inicialmente a implantação de ao menos uma creche para criança de zero a quatro anos de idade como componente obrigatório e a preocupação do desemprego, do subemprego, da baixa renda e do conseqüente recrutamento dos moradores pelos traficantes de drogas;

d) regularizar, do ponto de vista legal, as propriedades privadas e os espaços públicos: [...] foram implantadas as AEIS, Áreas de Especial Interesse Social." 

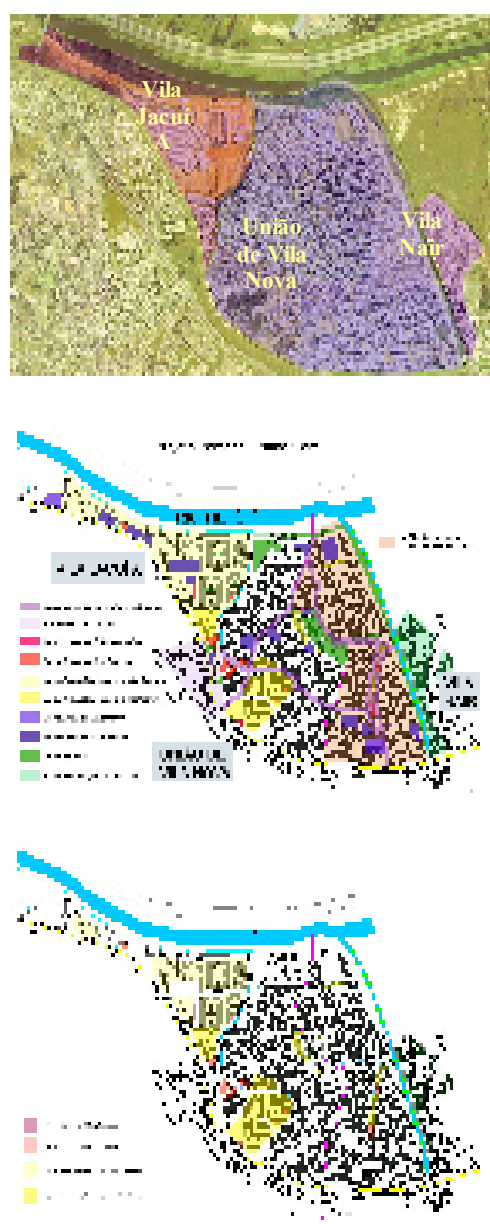

Figs. 72,73 e 74 - Projeto

Pantanal (CDHU, 2004)
Vários foram os projetos de urbanização de favelas implementados em diferentes cidades do Brasil, como expõem Abiko (2005) e Denaldi (2003). Na Região Metropolitana de São Paulo, o Governo do Estado de São Paulo iniciou sua atuação em favelas nos anos 1990. Na cidade de São Paulo, algumas intervenções merecem destaque.

A CDHU, empresa estadual executora das políticas habitacionais formuladas pela Secretaria Estadual da Habitação, e tem origem no período em que o governo estadual de São Paulo iniciava atividades na área da construção de habitações coletivas, em 1949, com a criação da Caixa Estadual de Casas para o Povo (Cecap), autarquia vinculada à Secretaria do Trabalho, Indústria e Comércio. Em 1968 a CECAP passou a obter recursos do Sistema Financeiro da Habitação (SFH), sob controle do BNH. Em 1975, deixava de ser uma autarquia para tornar-se uma sociedade anônima por ações, sob o nome Companhia Estadual de Casas Populares (também Cecap). Em 1980 era redenominada Companhia de Desenvolvimento de São Paulo (Codespaulo), sem alterar sua atuação, e ainda obtendo recursos do SFH. Em 1984, a Codespaulo tornou-se a Companhia de Desenvolvimento Habitacional $(\mathrm{CDH})$, vinculada à Secretaria Executiva da Habitação, cujos recursos provinham basicamente do Tesouro do Estado.

Em 1988 a Secretaria de Estado da Habitação transformava-se na Secretaria de Habitação e Desenvolvimento Urbano, acumulando as funções do Departamento de Obras Públicas (Deop) e da Companhia de Construção Escolar de São Paulo (Conesp). 


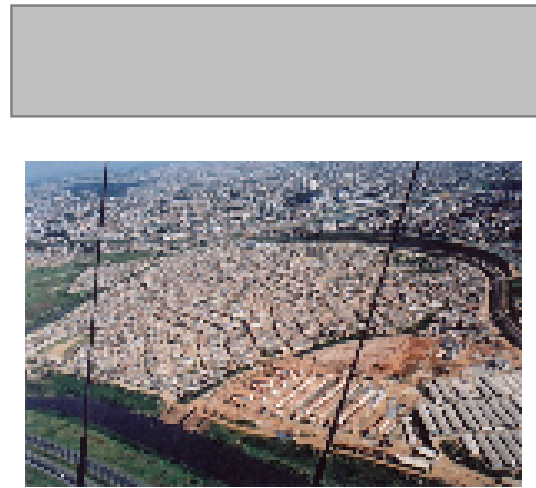

Fig. 75 - Projeto Pantanal (CDHU, 2001).

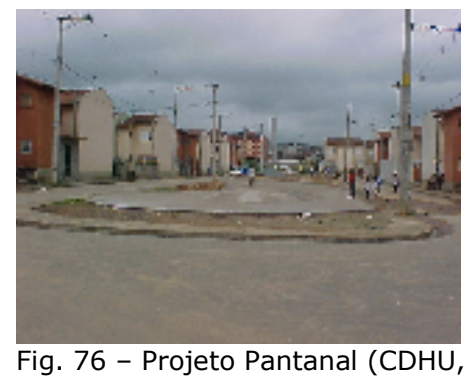
2004).

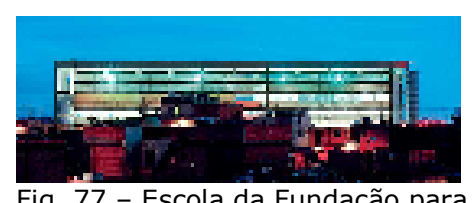

o Desenvolvimento da Educação (FDE) implantada na área do Projeto Pantanal em 2005 (ProjetoDesign, n. 314, abr. 2006).
A partir da reforma administrativa, a CDH passava a ser a Companhia de Desenvolvimento Habitacional e Urbano (CDHU), única empresa estadual de construção (COELHO, 2002).

Alinhada às políticas do Banco Mundial a partir dos anos 1990, a atuação da CDHU:

Com o final do BHM em 1986, a CDH não contava mais com o fluxo de recursos financeiros para a produção habitacional que tivera até então, e o governo estadual de São Paulo optou por investir recursos próprios para que fosse viabilizada a produção em escala. Esse período:

"[...] iniciado em 1987, se caracterizou pela desapropriação de grandes áreas na Região Metropolitana de São Paulo para a execução de projetos direcionados a uma demanda organizada que, nos anos de 1986 e 1987, invadira cerca de duas centenas de terrenos públicos e privados. Esse conjunto de projetos foi denominado Programa SH1. Outra característica foi a ampliação do atendimento a municípios do interior do Estado, num Programa Habitacional chamado SH2, que guardou algumas semelhanças com o PMH, pela contrapartida exigida à Prefeitura Municipal (terreno, infra-estrutura), mas que representava sua negação, pela não utilização da mão-de-obra da população.

Nos empreendimentos realizados no interior as famílias eram subsidiadas pela não incidência das contrapartidas da Prefeitura Municipal. Na Região Metropolitana, ao contrário, todos os custos eram incidentes - o que tornava o preço final da unidade posta à venda muito maior do que as construídas no interior do Estado. A fim de viabilizar [...] o atendimento à demanda de baixa renda e tendo em vista os custos de produção, notadamente aqueles referentes aos terrenos desapropriados foram implantados um sistema de subsídio à família de todos os custos incidentes. Criou-se, porém, um mecanismo que aproximava a prestação a ser paga pela família à sua efetiva capacidade de pagamento. Famílias com menor renda pagariam valores menores de prestação; aquelas que 


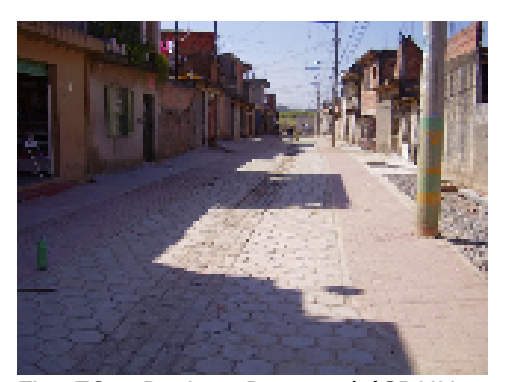

Fig. 78 - Projeto Pantanal (CDHU, 2004).

$\begin{array}{cc}\begin{array}{c}\text { Renda } \\ \text { familiar } \\ \text { (salários } \\ \text { mínimos) }\end{array} & \begin{array}{c}\text { Limite máximo de } \\ \text { comprometimento } \\ \text { de renda } \\ \text { familiar) }\end{array} \\ 1 \text { a } 3 & 15 \% \\ 3 \text { a } 5 & 15 \text { a } 20 \% \\ 5 \text { a } 8,5 & 20 \text { a } 25 \% \\ 8,5 \text { a } 10 & 25 \text { a } 30 \%\end{array}$

tivessem rendas maiores pagariam prestações maiores. O valor da prestação devida pelo mutuário, portanto, era o valor da prestação real menos a capacidade de pagamento da família. O resto era coberto pelo que se convencionou chamar de "bônus". Esse bônus é regressivo ao longo do período de financiamento.

A partir de 1990, a CDHU foi marcada por um incremento ainda maior na produção em virtude da implantação de um fluxo ininterrupto de recursos financeiros. Foi aprovado dispositivo legal que destina os valores auferidos a título do aumento da alíquota do ICMS, em 1 ponto percentual, à produção habitacional. Trata-se da Lei 6556/89, promulgada no final de 1989, que passou a vigorar no exercício fiscal de 1990. É importante lembrar que a Lei que aumenta a referida alíquota tem sido renovada anualmente. Com recursos próprios [...] a CDHU [...] passou a praticar financiamentos com juros bem abaixo dos ofertados pelo mercado. Os juros cobrados pela empresa partem de uma taxa anual de $1 \%$ e vão até 5,5\%, para atender as famílias com renda mensal na faixa de 1 a 10 salários mínimos. Adotou-se, também, uma regra que limita os valores máximos das prestações a serem pagas de acordo com os rendimentos de cada família. $O$ modelo adotado fixa limites máximos das prestações de financiamento, conforme o quadro [ao lado]." (CDHU, [s.d.])

Uma das primeiras intervenções em favelas na CDHU foi a Urbanização Integrada do Jardim Santo André, no município de Santo André, região metropolitana de São Paulo. No início dos anos 1980, uma área de 1,5 milhões de metros quadrados de propriedade de CDHU $500000 \mathrm{~m}^{2}$ de área de preservação ambiental lindeira ao Parque Municipal do Pedroso foram invadidas, chegando a abrigar cerca de 8.000 famílias. 


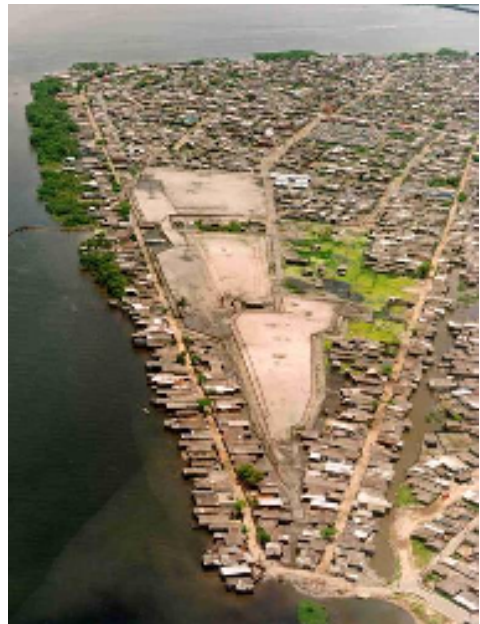

Fig. 79 - Vista geral da favela México 70, São Vicente, SP (CDHU, 2001)

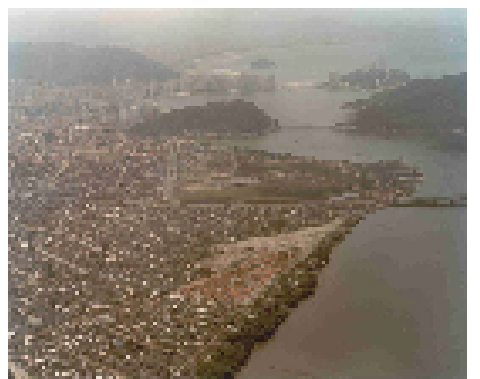

Fig. 80 - Vista geral da favela México 70, São Vicente, SP (CDHU, 2001)
A intervenção, em curso no período desta pesquisa, conta com a construção de novas unidades no interior da área (casas e condomínios de prédios) e a urbanização de vários núcleos de favelas, com instalação de infra-estrutura de água e esgoto, iluminação, pavimentação, substituição de moradias (construção de sobrados substituindo edificações sem condições de permanência) e canalização de alguns pequenos córregos. A topografia, bastante acidentada, torna mais complexa a intervenção.

A área de $500.000 \mathrm{~m}^{2}$, preservada, será destinada a parque a ser doado à municipalidade. Está prevista a construção de áreas livres para lazer e implantação de equipamentos comunitários, também em parceria com o Município de Santo André.

Outro projeto de grande vulto da CDHU é o Projeto Pantanal, também em curso no período desta pesquisa, no bairro de São Mateus, zona leste de São Paulo, uma área aterrada na várzea do rio Tietê, de propriedade da União, na qual foram inicialmente assentadas pelo governo estadual, em caráter que deveria ser provisório, no início da década de 1980, cerca de 300 famílias, chegando a cerca de 8.000 famílias no final do anos 1990 .

Por se tratar de uma várzea, um dos principais problemas era a macrodrenagem da área. Outro grave problema era sua conexão com o tecido urbano existente, já que se encontrava isolada entre o rio Tietê, o córrego do Jacu, a estrada de ferro da CPTM e o viaduto Santos Dumont.

O projeto engloba pavimentação diferenciada de ruas e vielas (uso de asfalto e pisos intertravados de concreto), obras de canalização de córregos, macrodrenagem, construção de transposição viária sob a estrada de ferro, construção de um parque junto à ampliação da avenida 
Jacu Pêssego, construção de grandes áreas livres como parte do projeto de drenagem, implantação de paisagismo nos condomínios existentes, construção de equipamentos públicos de educação, esporte e lazer, além de centros comerciais e creches, obras em parceria com ONGs (centro de nutrição) e construção de novas unidades internas à área para reassentamento de moradores (dadas as remoções expressivas em função das grandes obras viárias e de infraestrutura (CDHU, 2008).

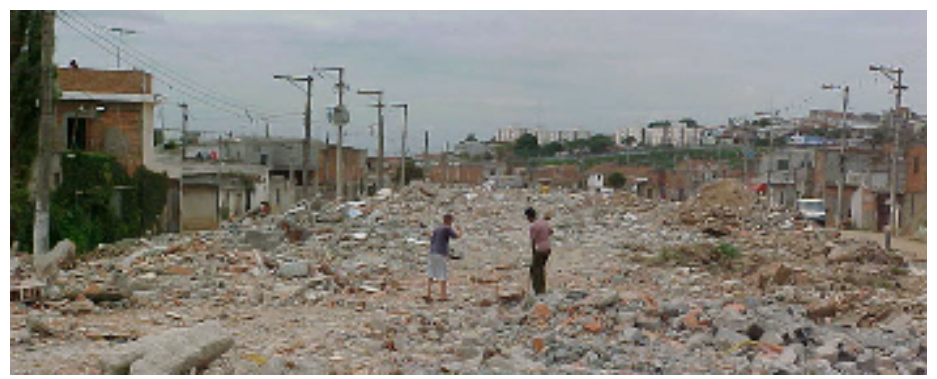

Fig. 81 - Projeto Pantanal - demolição da área do Parque Central (CDHU, 2004)

Esses dois exemplos de atuação da CDHU na urbanização de favelas em região metropolitana não serão aqui detalhados. 
A autora desta pesquisa desenvolveu em 2007, junto à Gerência de Produção de Projetos de Urbanização III, na CDHU, o projeto de urbanização da favela México 70, localizada no município paulista de São Vicente.

Esse projeto foi selecionado para análise neste estudo devido às possibilidades de pesquisa futuras ligadas à recuperação de áreas residenciais periféricas nas metrópoles brasileiras a partir dessa experiência. A análise se dará em duas direções:

a) urbanização de favela e recuperação ambiental;

b) requalificação urbana de assentamentos precários nas periferias metropolitanas.

A favela conhecida como México 70 situava-se em um aterro sobre o canal do Mar Pequeno, entre a avenida Angelina Preti da Silva e a Rodovia dos Imigrantes. Tal obra, realizada na década de 1930 , se destinava à ampliação da área de plantio do município.

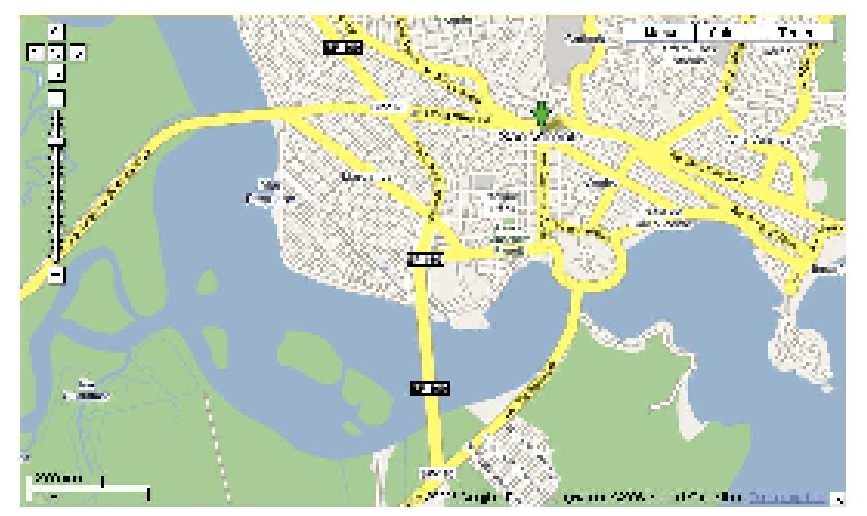

Fig. 82 - Localização da favela México 70, São Vicente, SP. (Fonte: Google, 2008.) 


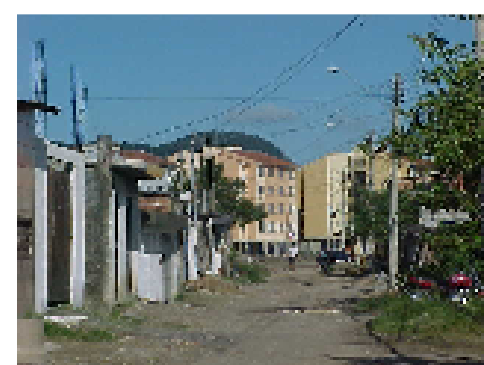

Fig. 83 - Favela México 70, São Vicente, SP, 2007 (CDHU, 2007)

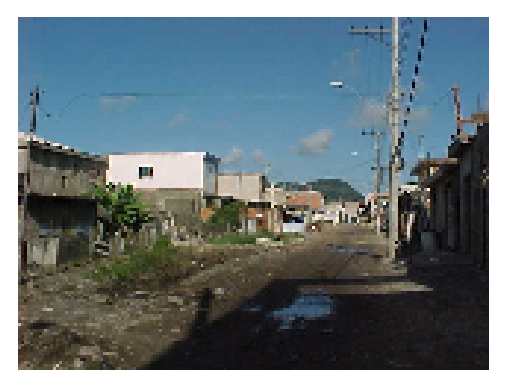

Fig. 84 - Favela México 70, São Vicente, SP, 2007 (CDHU, 2007)
A partir de 1950 a área começou a ser invadida, o que se acelerou por volta de 1970. Caracteriza-se, portanto, como uma favela metropolitana (Baixada Santista), em área ambientalmente frágil (mangue), com invasão de área pertencente à União - portanto com problemas fundiários e uma população de baixíssimo rendimento.

A área sob intervenção da CDHU abrigará ao final do projeto cerca de 1.640 famílias (990 na área de reassentamento e 650 na de urbanização) em $216.000 \mathrm{~m}^{2}$ em área de aterro e cerca de $40.000 \mathrm{~m}^{2}$ de mangue recuperado, atualmente ocupado e a ser reconstituído como mangue. 


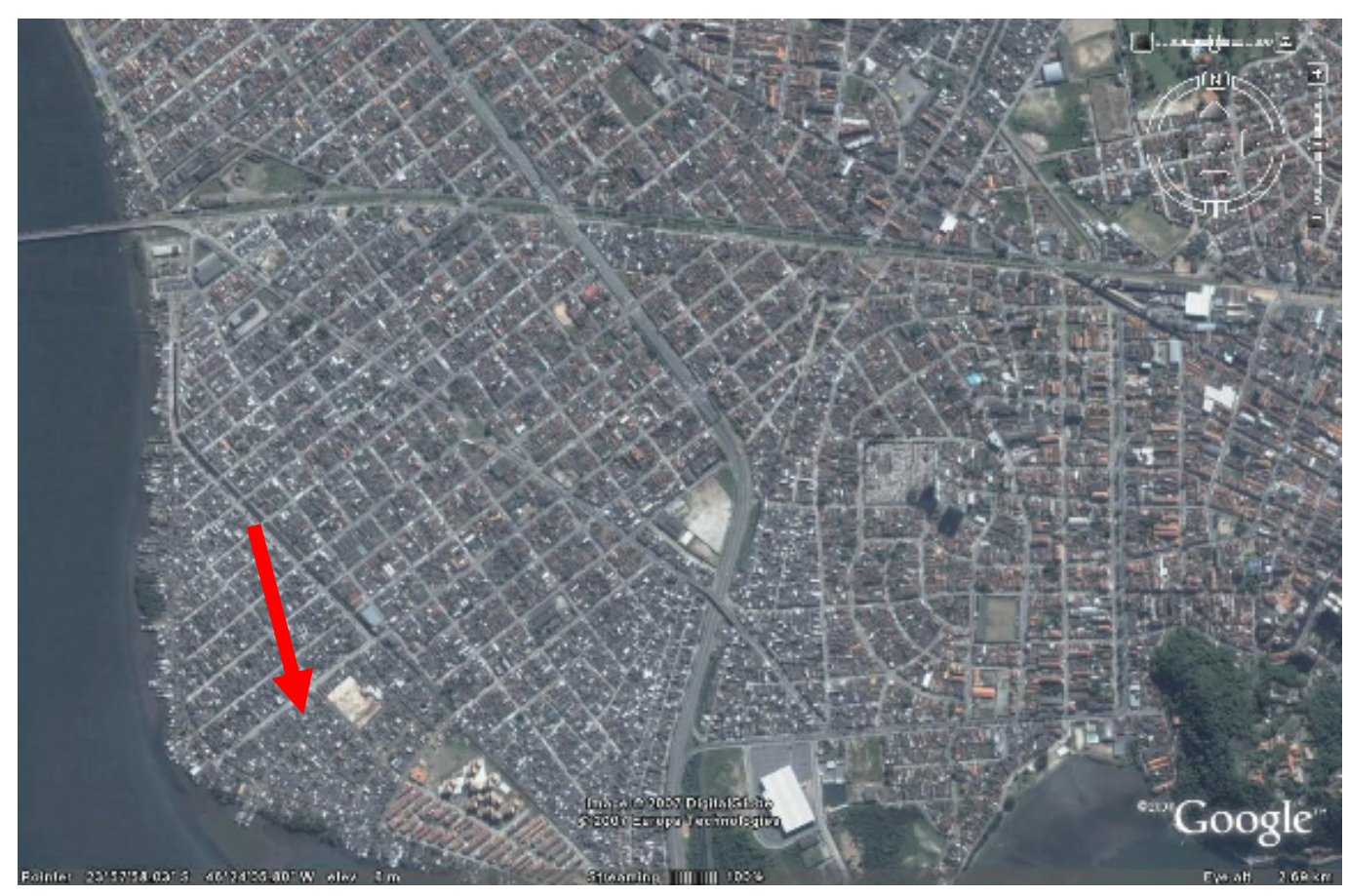

Fig. 85 - Favela México 70, São Vicente, SP. (Fonte: Google Earth, 2008) 


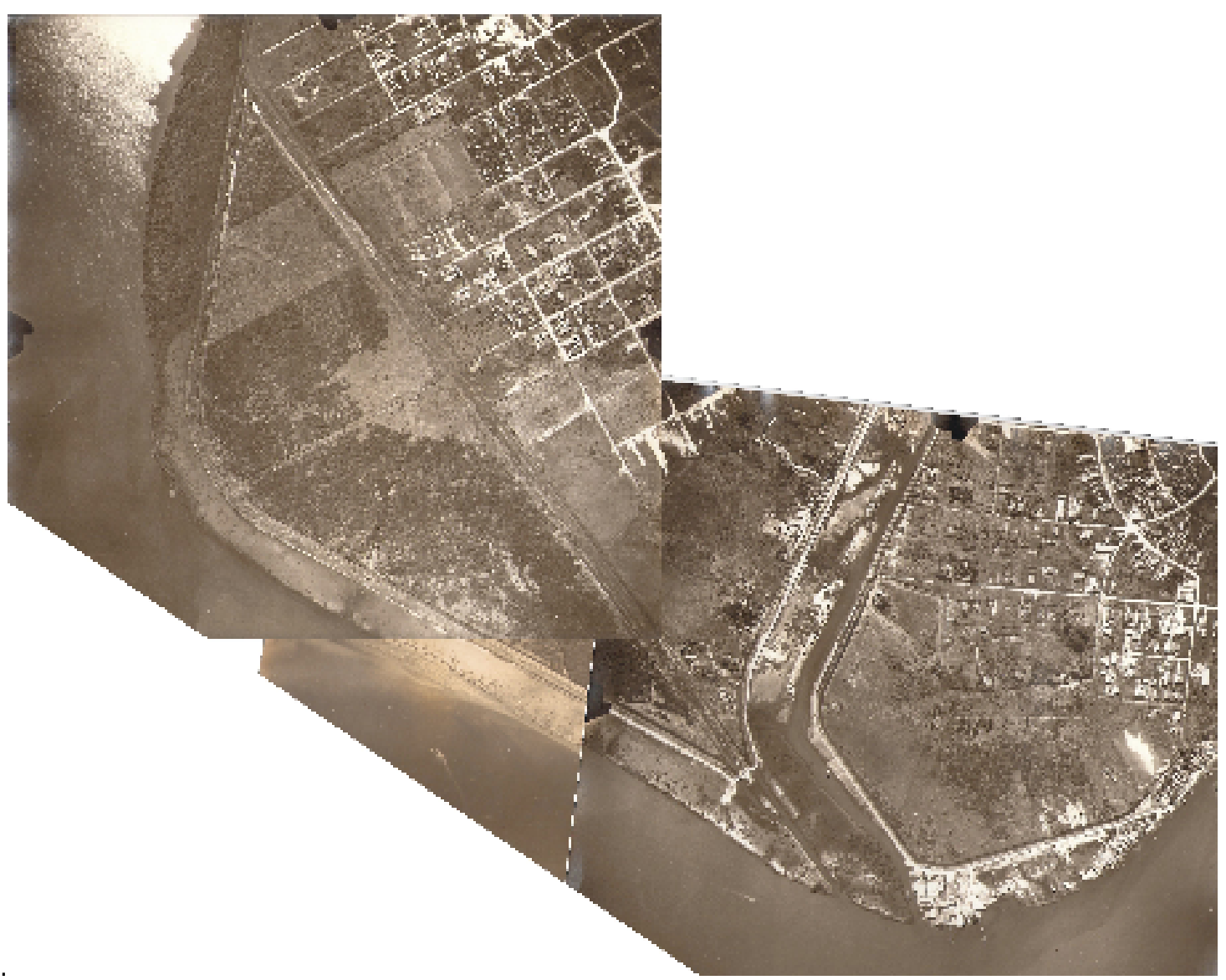

Fig. 86 - Aterro junto ao canal da Vila Margarida. (Imagem cedida pela Prefeitura Municipal de São Vicente.) 


\section{LOCALIZAÇÃO}

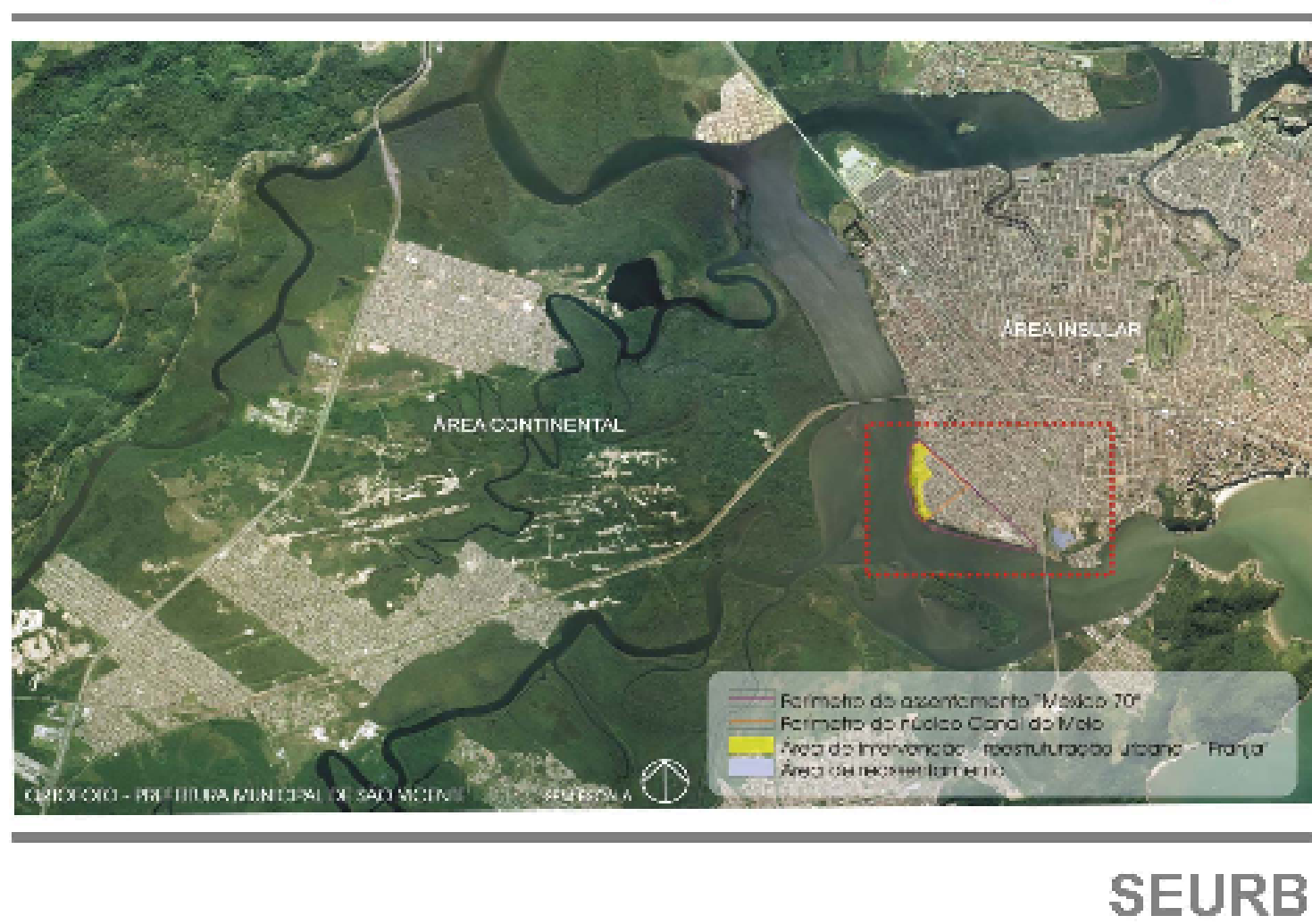

Fig. 87 - Favela México 70. (Imagem cedida pela Prefeitura Municipal de São Vicente.) 


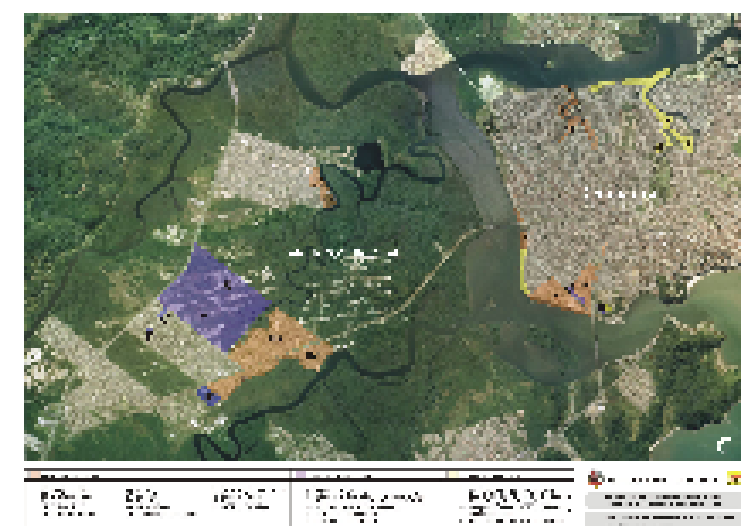

Fig. 88 - Vista geral - Programa Municipal de Erradicação de Palafitas.

(Imagem cedida pela Prefeitura Municipal de São Vicente.)

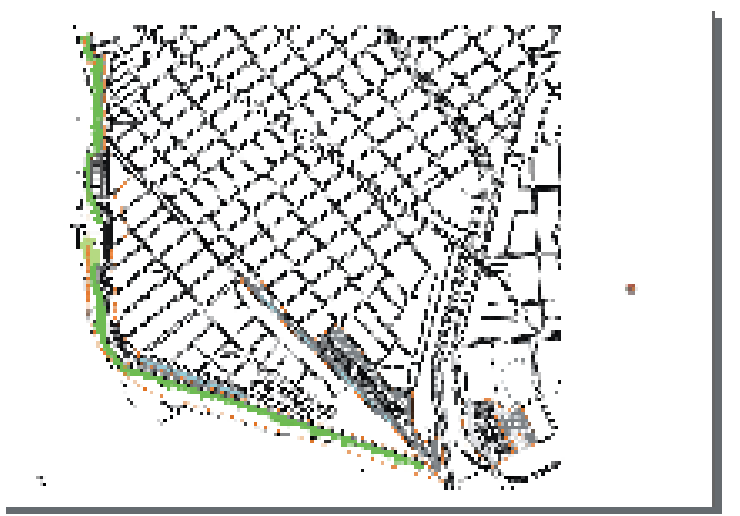

Fig. 89 - Poligonal México 70.

(Imagem cedida pela Prefeitura Municipal de São Vicente.) 
Empreendimento São Vicente $\mathrm{F}$ (como é designado na CDHU) Favela México 70

EQUIPE CDHU-

Superintendência(?) de Projetos GPPUIII - 2007

Gerente do projeto:

Arq. Renato Mario Daud

Gestor do Projeto:

Eng. Francisco S. Santos

Arquiteto - Projeto de Urbanização Setores 1 e 2:

Arq. Assunta Viola

Técnico Social:

Angélica Bichir Invernão

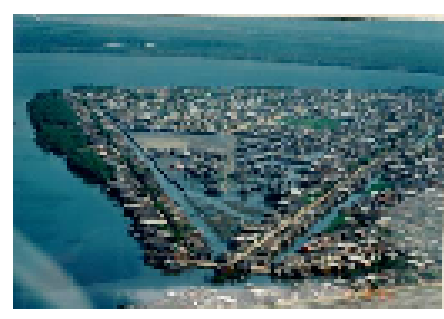

Por se tratar de um aterro em mangue, o quadro anterior à intervenção era bastante grave. Inundações constantes assolavam a região, cujo nível médio era mais baixo que o nível de maré. A drenagem da gleba era um dos pontos cruciais a ser enfrentado.

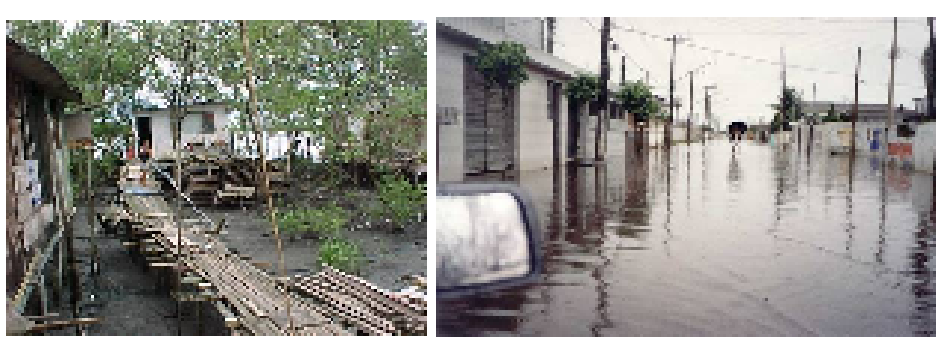

Fig. 90 - Favela México 70, São Vicente, SP - Setor de substituição de moradias e setor de urbanização (CDHU, 2001)

As principais diretrizes traçadas foram:

1. identificação das áreas com maiores problemas de inundação e avaliação das alternativas de solução do problema;

2. identificação das áreas passíveis de urbanização e de construção de novas unidades habitacionais.

Foram identificados dois setores espaciais: o de reassentamento e o de urbanização. Seriam necessárias obras de aterro e construção de novas habitações, além de obras de urbanização. Os principais objetivos nesses dois setores eram:

1. Setor de Reassentamento: relocação da população e implantação de sistema viário e infraestrutura. 
2. Setor de Urbanização: obras de infra-estrutura e de melhorias no sistema viário interno e nas habitações; aterro quando necessário no interior das quadras; substituição das moradias precárias.

Segundo a equipe técnica responsável pelo projeto, o início dos trabalhos deveria ser precedido de algumas medidas.

"Para os dois setores, a solução para a drenagem das águas pluviais foi determinante na definição urbanística. Os sistemas projetados são diferenciados em função das características de ocupação de cada setor." (CDHU, 2007.)

\section{Setor de Reassentamento}

Foi necessária a construção de 120 alojamentos provisórios no Setor de Urbanização para reassentamento de 256 famílias no Conjunto Habitacional São Vicente C (CDHU), na Cidade Náutica. ${ }^{33}$

Nesse caso, "a necessidade de alteamento da área como um todo para possibilitar sua drenagem, através da execução de aterros hidráulicos cujo tempo de permanência depende da estabilização dos recalques do solo, consistiu e consiste num dos grandes desafios do empreendimento" (CDHU, 2007).

Só então foi possível dar início aos trabalhos de implantação das edificações projetadas.

33 O entrosamento com a população residente é fundamental. Para dar início aos trabalhos, é necessário um trabalho cadastral com a população, um trabalho de convencimento, negociações quando há remoções, reassentamentos, alternativas etc. Muitas vezes as famílias resistentes tornam necessário modificar o projeto. 

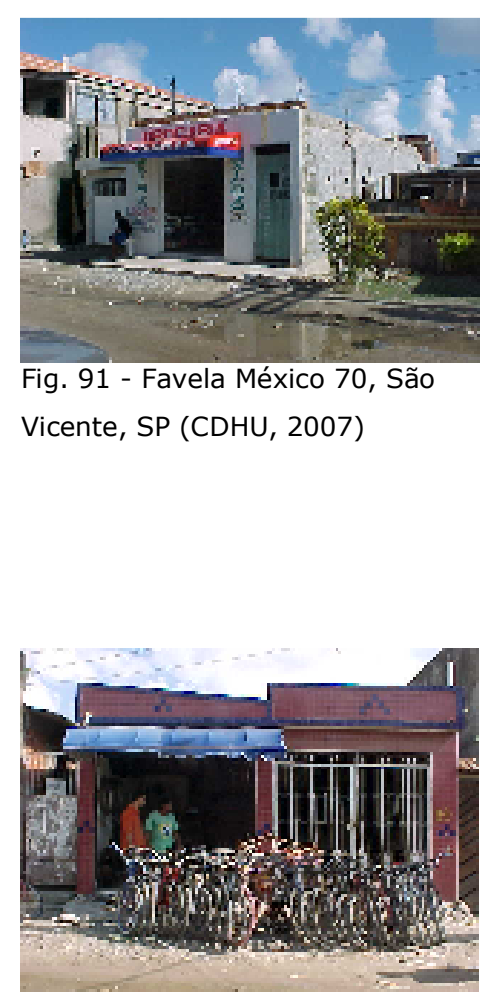

Fig. 92 - Favela México 70, São Vicente, SP (CDHU, 2007)

\section{Setor de Urbanização}

Uma das grandes dificuldades no Setor de Urbanização era ainda a questão das inundações durante chuvas mais fortes, em razão da baixa declividade e da proximidade com o nível do mar. Foram projetados canais de drenagem superficial conectados a um canal de acumulação junto ao canal do Mar Pequeno. A eles foi conectado o restante do sistema de drenagem.

O Setor de Urbanização foi então subdividido em outros dois setores (1 e 2).

O Setor 1 de Urbanização compreendia a porção leste da área a partir de uma rua que unia os dois setores maiores.

Para dar seqüência ao trabalho já iniciado, o projeto do Setor 2 de Urbanização tinha como premissas básicas:

- O Setor de Reassentamento já se encontrava ocupado.

- No Setor de Urbanização, o plano diretor já estava desenvolvido e os sistemas de água, esgoto e drenagem já estavam projetado.

- As obras de abastecimento de água e coleta de esgoto teriam início, devendo-se finalizar o projeto de urbanização, com a escolha das moradias a serem removidas.

As únicas diretrizes urbanísticas adotadas foram: não seriam permitidas moradias com menos de $45 \mathrm{~m}^{2}$ edificados; no caso de ausência de equipamento sanitário, deveria ser implantada uma unidade sanitária na moradia; as moradias deveriam oferecer condições para a implantação da rede pública de infra-estrutura, assim como sua futura manutenção; os lotes deveriam ter acessos diretos a vias (ou vielas) públicas; as vielas não poderiam ter menos de $4 \mathrm{~m}$ de largura 
(de lote a lote); a substituição de moradias só seria possível caso houve condições de se removerem muitas delas e construir-se ou um prédio ou um conjunto de várias casas, dada a fragilidade do solo.

O processo de projeto teve início com a caracterização física da área. A massa construída foi analisada de acordo com alguns critérios: qualidade das construções, nível das soleiras acima do grade da rua, possibilidade de remoções maiores para construção de novas edificações.

Inicialmente foram propostos alguns bolsões de remoções, nos quais poderiam ser implantadas as tipologias já em uso no conjunto São Vicente F4 (empreendimento interno à área, com 120 apartamentos), que estava em construção. Foram propostos três bolsões para o Setor 1 dois para o Setor 2 .

Foram levados em consideração os seguintes pontos, como relatório técnico desenvolvido junto a Gerência de Produção de Projetos de Urbanismo III (GPPUIII):

- os projetos traçados para as infra-estruturas de abastecimento de água, coleta de esgoto, drenagem e instalação de eletricidade;

- o projeto de arruamento proposto, cujas vias constituiriam também os principais troncos de distribuição da infra-estrutura e drenagem superficial;

- as intervenções urbanas em curso: construção do conjunto São Vicente F4 (120 unidades), instalação das estações elevatórias de esgoto, nova rede de distribuição de água e rede de esgoto.

Para permitir o conhecimento da realidade da favela, foram feitas com o apoio da equipe social da CDHU diversas vistorias na área. Nelas observavam-se fundamentalmente a dinâmica 
interna da comunidade e o modo como esta se relacionava com o espaço. Por vezes, a configuração existente auxiliava essa dinâmica; por outras, dificultava-a.

Procuraram-se identificar atividades eminentemente urbanas na ocupação. Levaram-se em conta, entre outros aspectos, áreas que apresentassem comércios ou serviços, áreas de maior permanência de pessoas na rua, a relação de cada uma das moradias entre si e com o terreno, áreas de adensamento, existência de multiplicidade de usos, locais com alguma atividade de cunho cultural de grande importância (em razão do tipo de entretenimento, equipamento etc. utilizado pelos moradores), algum uso específico de moradia diverso da cultura urbana vigente nas metrópoles brasileiras, presença de carros, motos e bicicletas, quantidade de crianças pequenas. A identificação desses aspectos foi feita em cada uma das quadras, varrendo-se toda a área com visitas a cada uma das moradias. 
Após as primeiras análises físicas, verificou-se a forma de relacionamento da moradia com o

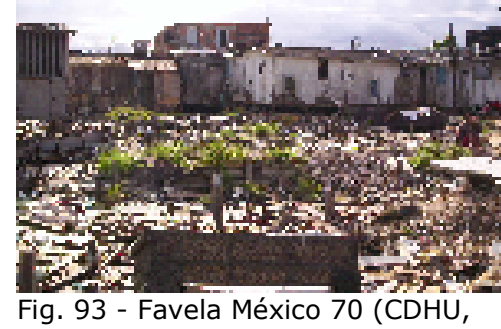
2007)

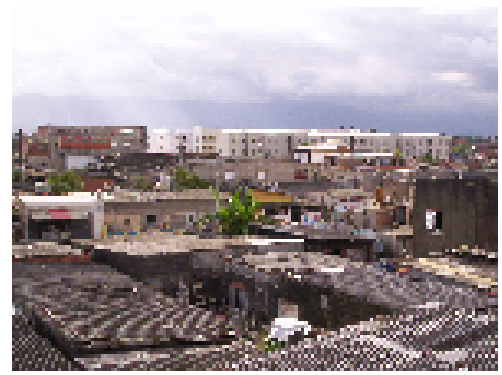

Fig. 94 - Favela México 70 (CDHU, 2007) terreno. As moradias não estavam implantadas ao acaso. Cada uma possuía seu "lote", e a idéia de posse, muito presente, isso facilitou o trabalho de parcelamento da gleba no desenvolvimento do projeto. Por outro lado, dificultou a implantação da idéia original dos bolsões: a dificuldade de convencimento quanto à remoção de edificações que não apresentavam nenhum problema quanto à construção nem impediam nenhuma das obras previstas inviabilizou a execução da obra dos bolsões 1, 2 e 3, de um total de cinco bolsões.

Verificaram-se com essas vistorias:

- a forma de ocupação residencial na área, com vistas à instalação das infra-estruturas, garantindo o atendimento, a manutenção e operação de todo o sistema;

- a cota aproximada de cada moradia (a ser confirmada no projeto executivo) em relação às vias, para evitar soleiras de nível inferior ao grade de projeto;

- a disposição física de cada moradia dentro das quadras e a relação física entre elas nas quadras;

- as características das moradias quanto às seguintes configurações e materiais de construção: alvenaria ou madeira; térreas ou assobradadas; condições físicas da moradia; presença ou não de instalações sanitárias e hidráulicas; captação e destino do esgoto doméstico; captação e destino das águas pluviais; quantidade de aberturas para ventilação e insolação;

- possibilidades de alteamento do nível interno da moradia em caso de cota inferior ao grade;

- acesso direto a partir do sistema viário proposto; 


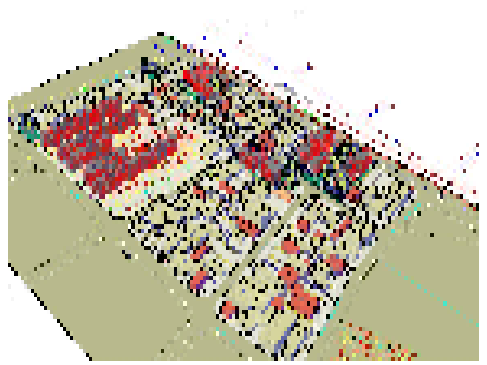

Fig. 96 - Projeto de urbanização, Setor 1 (CDHU, 2007)

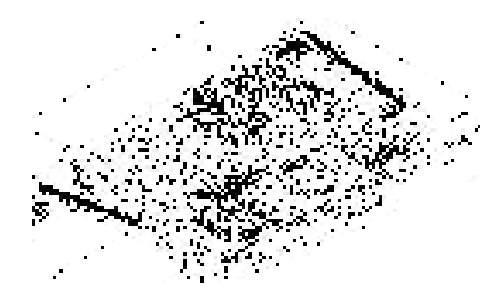

Fig. 97 - projeto de urbanização, Setor 1 (CDHU, 2007)

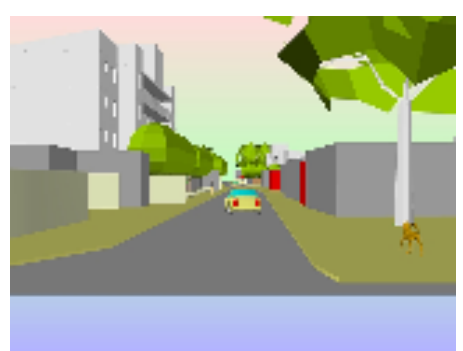

Fig. 98 - Vista Geral do projeto de urbanização setor 1 (CDHU , 2007)

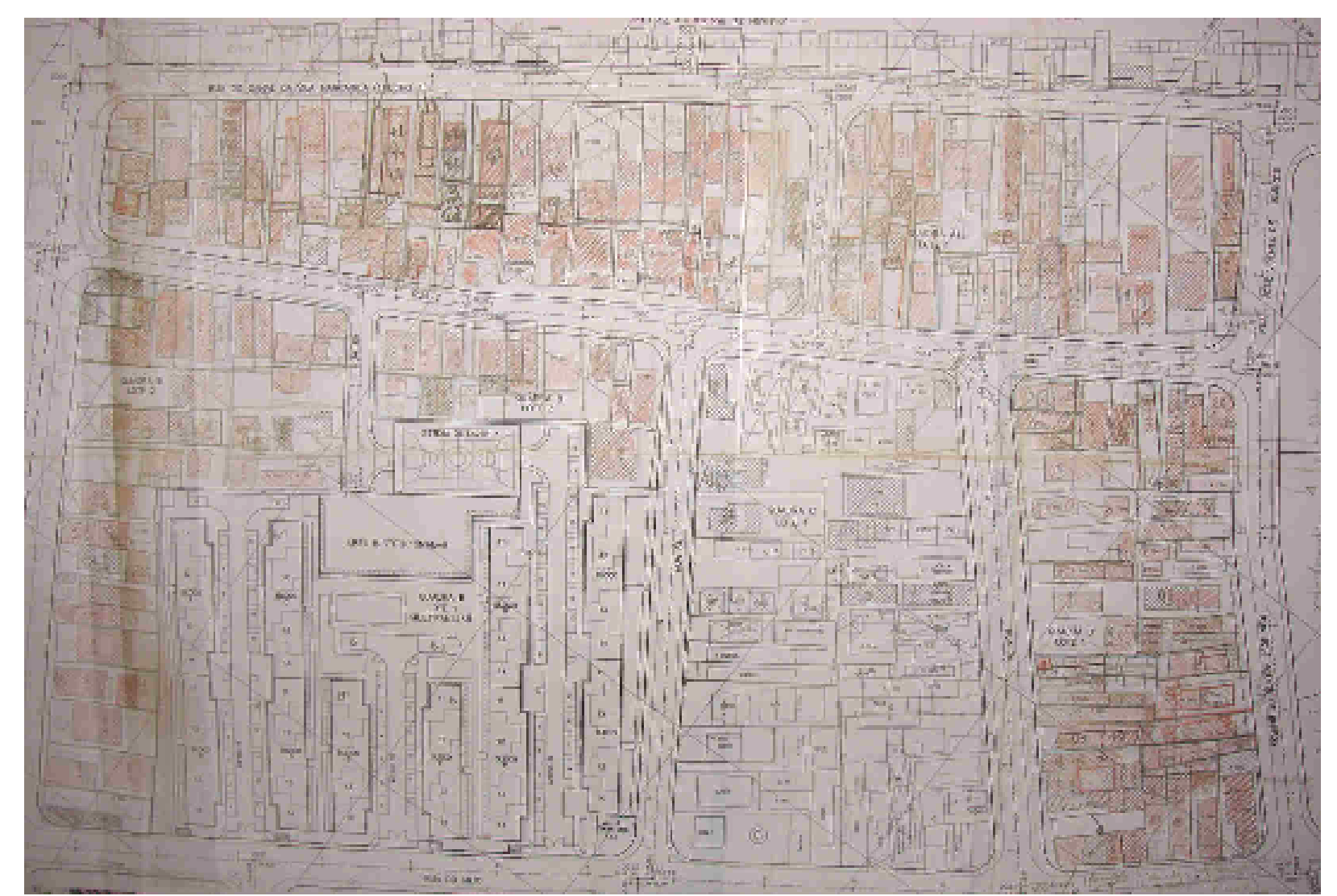

Fig. 95 - Favela México 70, São Vicente, SP. Levantamentos feito em obra - anotações para Projeto 1, Setor 1 de Urbanização (CDHU, 2007)

- possibilidade de construção de um lote individual ou condominial que tivesse ligação direta com o sistema de distribuição das infra-estruturas;

Assunta Viola Mar/2009 188 
- o uso de casas sobrepostas principalmente a comércio, mas em alguns casos, a moradias, alinhadas ao limite frontal do "lote";

- a existência de comércio e serviços principalmente na rua do Meio e na rua Alcides, mas com algumas ocorrências pontuais no interior da área;

- o uso de um único "lote" para a moradia e para o comércio;

- o cercamento com muros na maioria das moradias junto à via de acesso e nem sempre internamente à quadra;

- a existência de generosos recuos frontais na maior parte das moradias térreas - que possibilitam ampliações futuras;

- a existência de aberturas laterais e nos fundos (janelas) das moradias, junto ao limite do "lote" (voltadas ao vizinho);

- a precária condição física externa da maior parte das moradias, que muitas vezes não corresponde a um certo "conforto" interno;

- a existência de algumas moradias construídas em madeira, de boa qualidade construtiva, bom dimensionamento e disposição interna dos cômodos, contando com iluminação ventilação e insolação;

- o uso intenso de bicicleta, poucos veículos e garagens; 


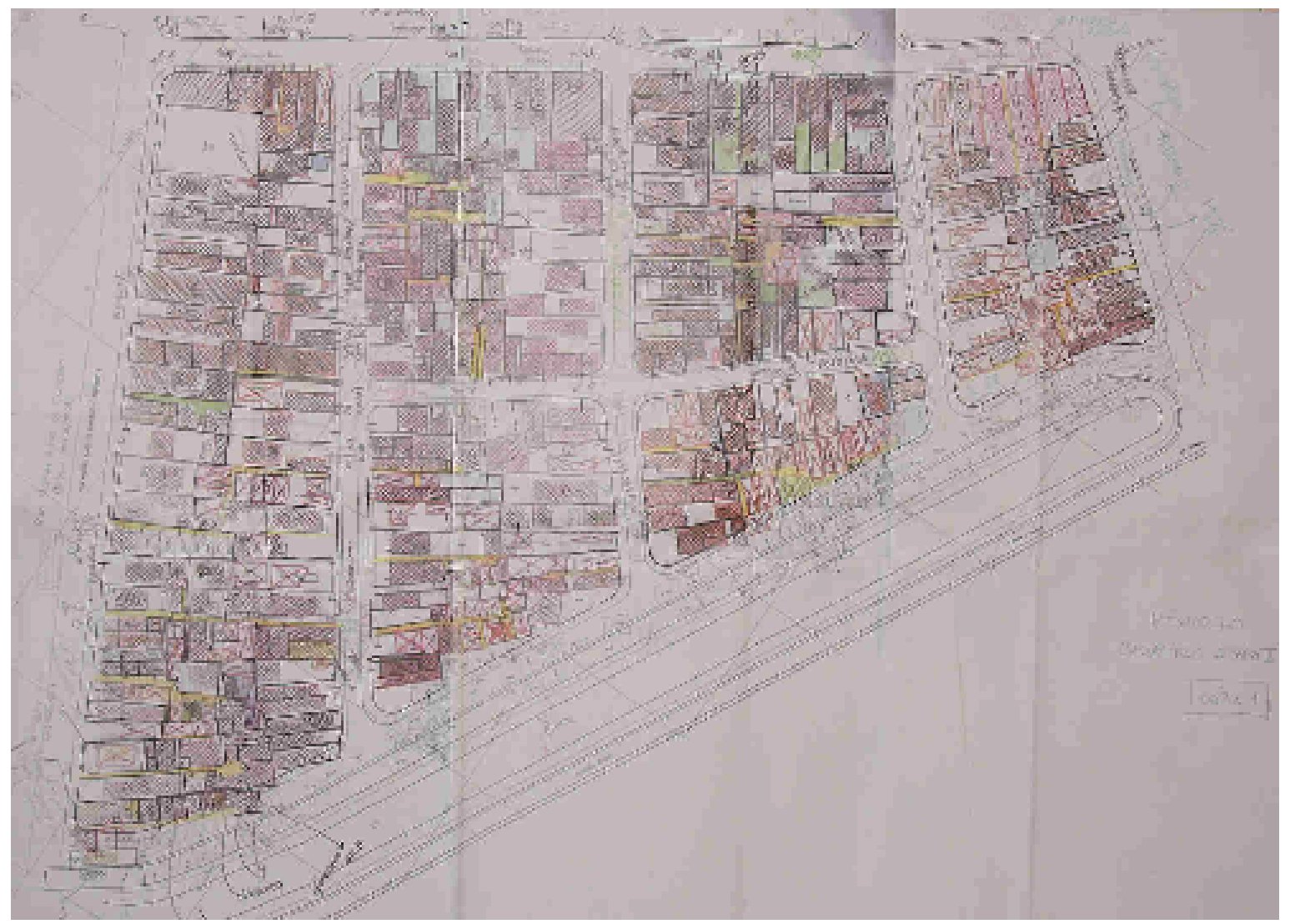

Fig. 99 - Levantamentos feito em obra - anotações para Projeto 1 Setor 2 do Setor de Urbanização (CDHU, 2007) 


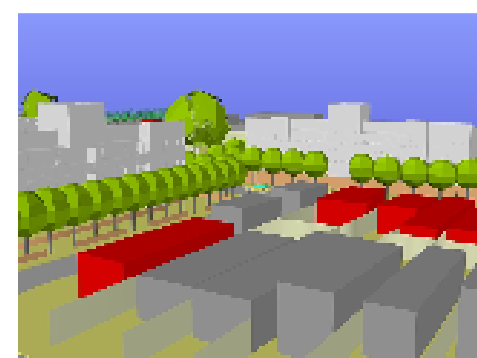

Fig. 100 - Projeto de urbanização, Setor 1 (CDHU, 2007)

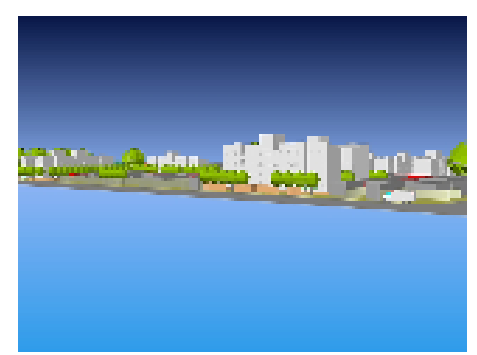

Fig. 101 - Projeto de

urbanização, Setor 1 (CDHU , 2007)
- o uso da rua como espaço de encontro e permanência de jovens e pessoas de mais idade cadeiras na calçada;

- no Setor 1 observou-se um adensamento junto às principais esquinas na forma de moradias sobrepostas (condomínios verticalizados) construídos por residentes na favela que alugam essas unidades;

- no Setor 2, junto à rua Alcides, observou-se adensamento pela construção de cômodos enfileirados com alguma instalação hidráulica e sanitária internamente a lotes profundos, para aluguel;

- no Setor 2, perpendicularmente à rua Alcides, observou-se adensamento com implantação de moradias em seqüência, seguindo estreitas vielas em direção ao miolo das quadras (prédios deitados). 


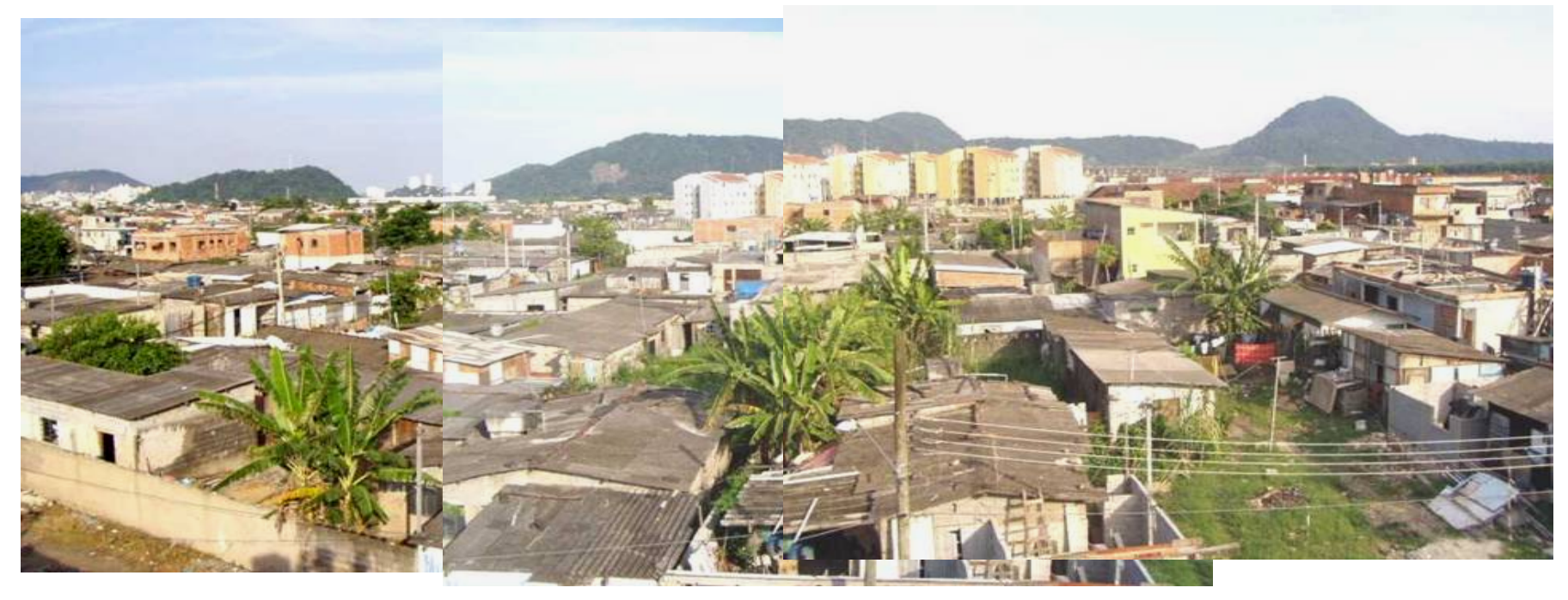

Fig. 102 - Vista do Setor 1 de Urbanização - Favela México 70, São Vicente, SP (CDHU, 2007) 


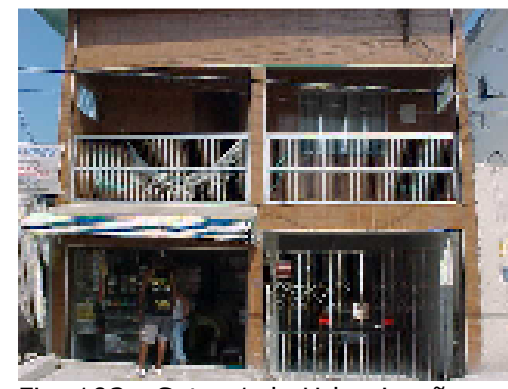

Fig. 103 - Setor 1 de Urbanização, Favela México 70 (CDHU, 2007)

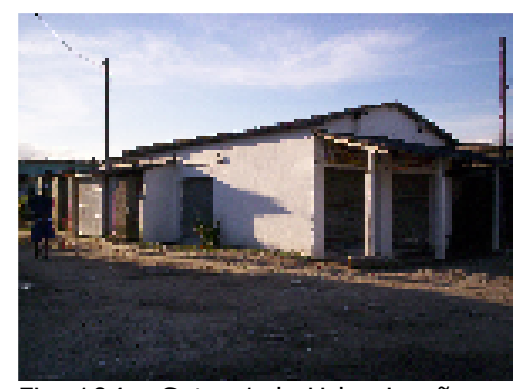

Fig. 104 - Setor 1 de Urbanização, Favela México $70(\mathrm{CDHU}, 2007)$
Todas essas informações foram utilizadas na elaboração do projeto de urbanismo. Como se tratada da primeira experiência, essas informações, sua seqüência e seu encadeamento não foram sistematizados.

Verificou-se que havia adensamentos localizados junto ao ponto de ônibus e nas esquinas, sob duas formas: como unidades para aluguel em construções verticalizadas (de até três andares) e como unidades térreas (geminadas e individuais) internas a um mesmo "lote", formando uma pequena "vila".

Concluiu-se que a área apresentava características nitidamente urbanas, tanto de moradia como de entorno, mas deficientes nos dois aspectos. Não se constataram características particulares quanto aos hábitos sociais e equipamentos urbanos usualmente presentes nas áreas urbanas da região.

O projeto de urbanização procurou enfatizar as características urbanas já presentes e implementar significativas melhoras urbanas na totalidade da área, utilizando-se dos elementos disponíveis - e já reconhecíveis pela população. O projeto não abarcava a deficiência interna das moradias, salvo quando se tratava de problemas de instalações sanitárias, item que não apresentava nenhuma deficiência séria, já que a quase totalidade das moradias dispunha delas. Os equipamentos institucionais já tinham sido estudados em etapa anterior, e por isso não fazem parte do escopo deste estudo.

Empiricamente, chegava-se a algumas conclusões iniciais. 

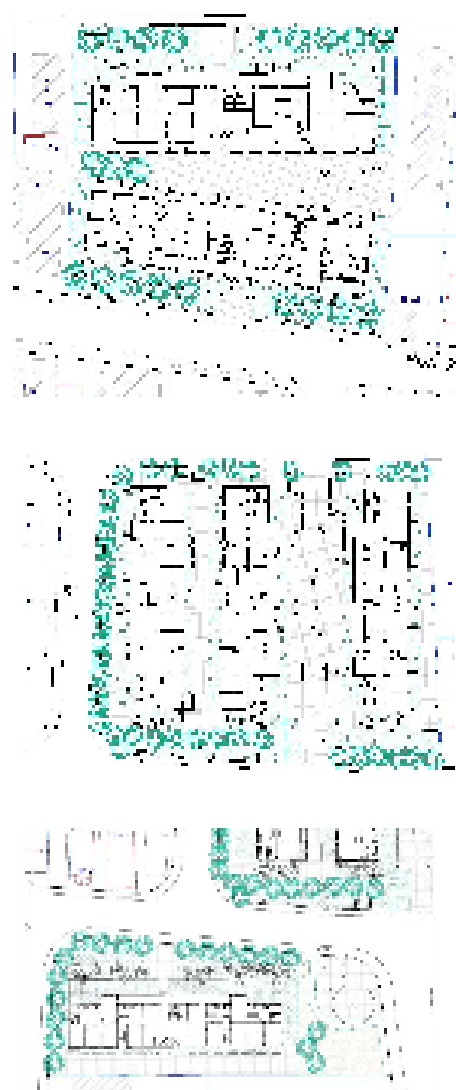

Fig. 105 - As três implantações, no projeto de urbanização. Setor 1, Favela México $70(\mathrm{CDHU}$, 2007)
A área não apresentava nenhuma forma de organização comunitária que se diferenciasse do restante da cidade. Distinguia-se apenas na precariedade, característica que mais saltava à vista. Embora fosse uma área segregada, o acesso à vida urbana de alguma forma estava garantido.

Os hábitos eram eminentemente urbanos, ainda que precários. A informalidade parecia não impor nenhuma característica específica ao espaço construído, tanto no agenciamento interno quanto no espaço externo resultante; não parecia criar uma cultura específica, criativa, original, inventiva, mas deixava clara a falta de recurso e de alternativas. A precariedade, sim, se manifestava. A existência da favela como realidade construída deixava claro um fato: a baixa renda familiar.

O projeto de urbanismo, a partir dessa análise, propõe:

1. O parcelamento das quadras com manutenção, dentro do possível, da estrutura dos "lotes" existentes.

Quando a situação física não permitia que cada moradia - ou um conjunto coeso de moradias -- fosse mantido de forma a definir um "lote", propunha-se a remoção (levando em conta a qualidade da moradia e a impossibilidade de instalação das redes de infra-estrutura). 0 parcelamento só seria efetivamente implantado com a construção de divisas entre os lotes, sendo esse item posteriormente detalhado pela equipe de projeto.

O resultado desse parcelamento garantiria: o espaço mínimo necessário para a construção de uma moradia unifamiliar no "lote" resultante $\left(45 \mathrm{~m}^{2}\right.$, como inicialmente definido); a compensação com áreas para ampliação das moradias atingidas por obras de urbanização; a possibilidade de construção de aberturas para ventilação e iluminação nas moradias mantidas; a 

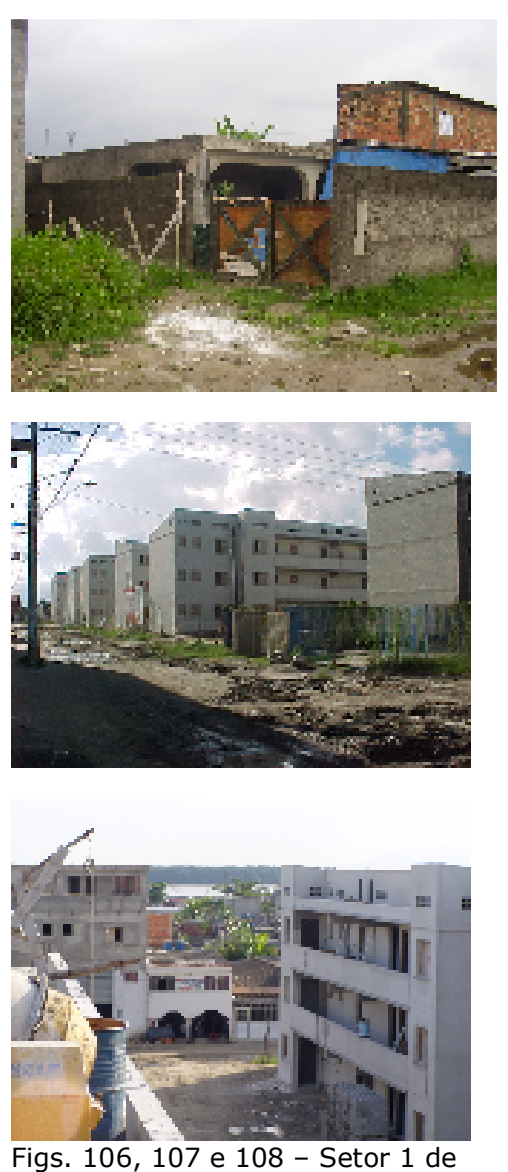

Urbanização F4, Favela México 70 (CDHU, 2007) possibilidade de substituição de moradias de madeira pelas de alvenaria, dependendo da possibilidade de investimento dos moradores; instalação de infra-estrutura diretamente das vias de distribuição; acesso direto pelas vias de circulação.

Nos setores de grande adensamento no interior das quadras, foram propostas vielas que garantiriam o acesso direto às moradias e a instalação de toda a infra-estrutura, diminuindo a ocorrência da configuração composta de casa da frente e casa dos fundos.

A dimensão das vielas e praças internas seguiu as determinações das concessionárias para operação e manutenção dos sistemas de fornecimento (mínimo 4 m).

Com isso, o parcelamento e a implantação de novas vielas exigiram algumas remoções e reformas. 


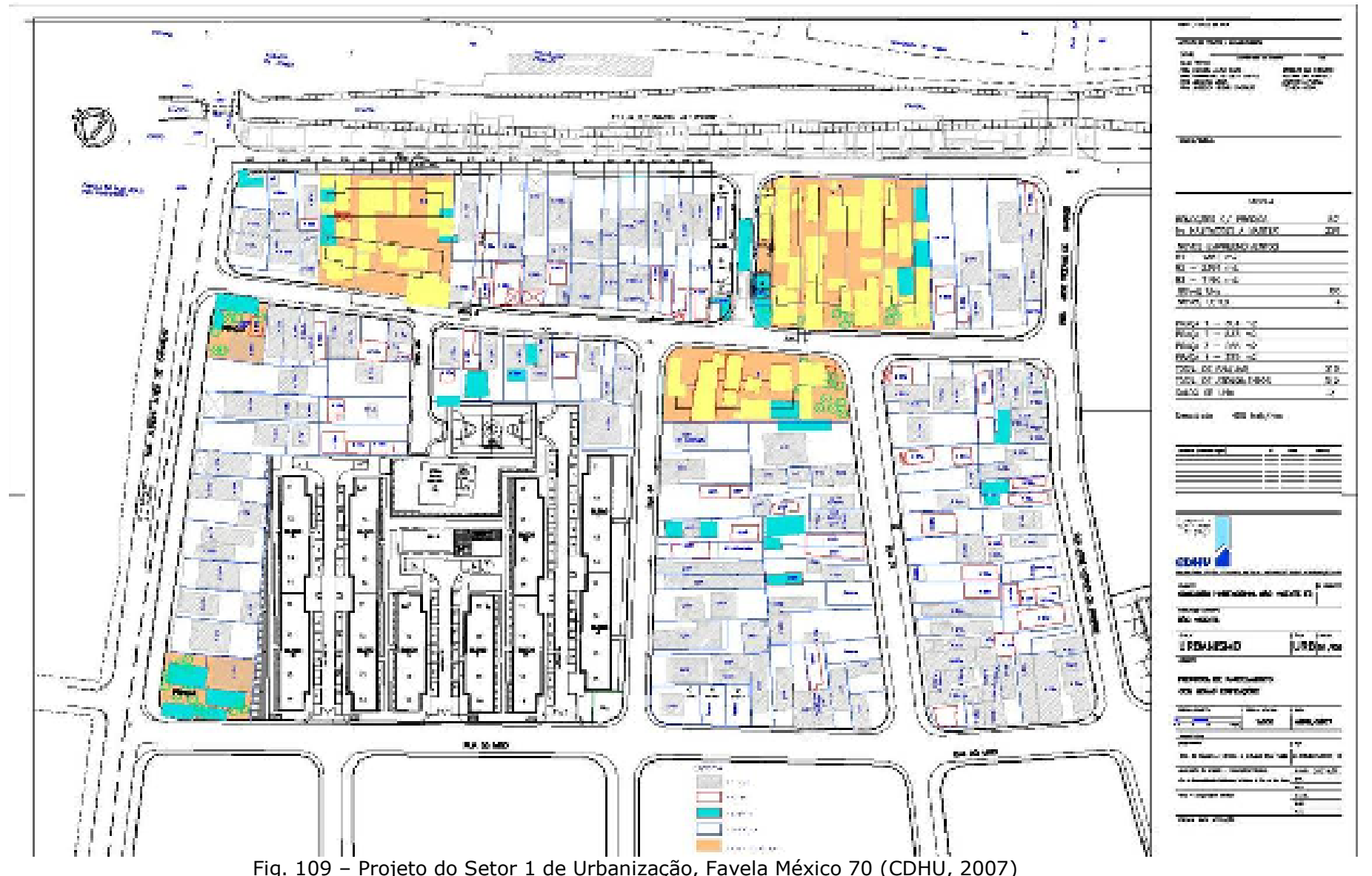




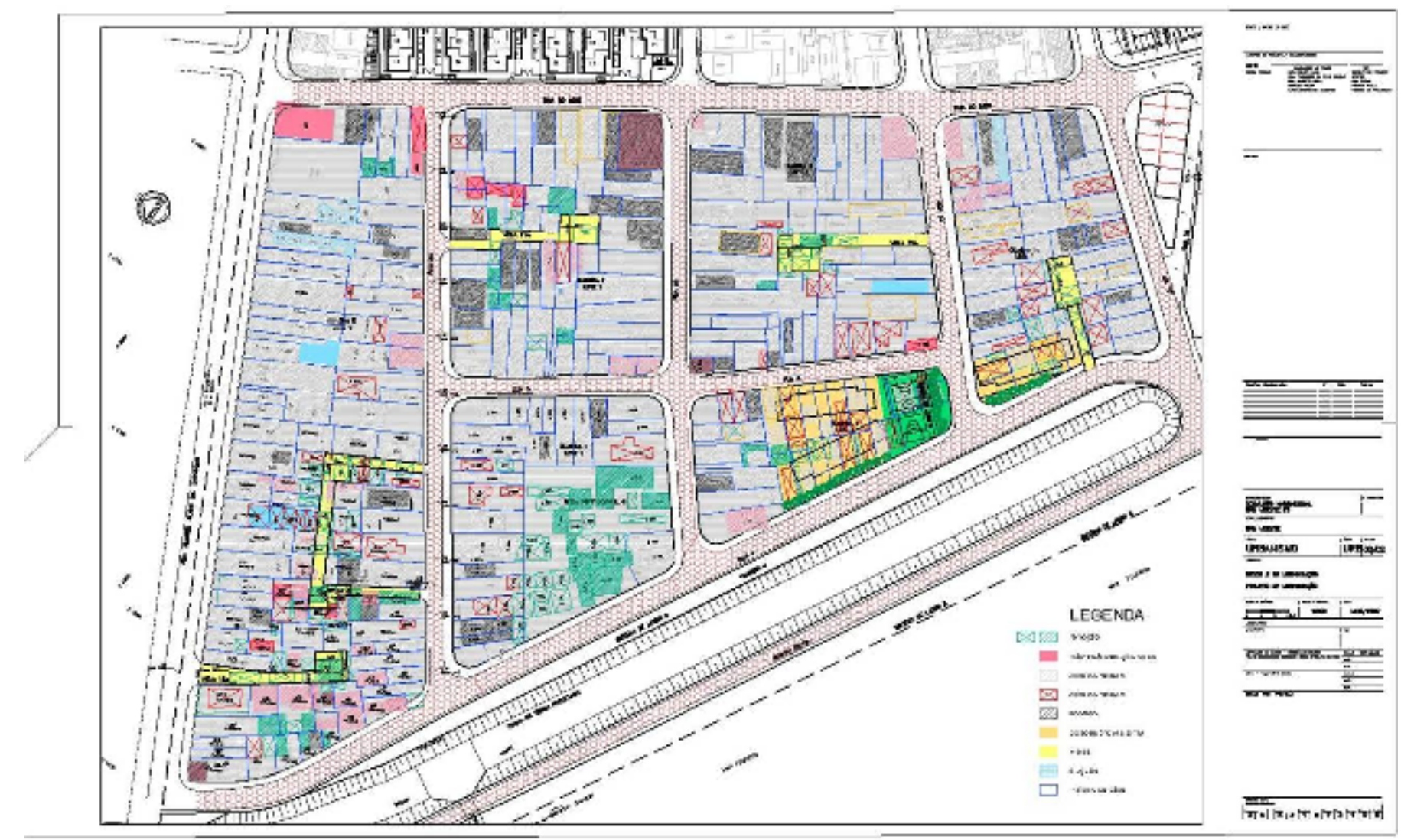

Fig. 110 - Projeto do Setor 1 de Urbanização, Favela México 70 (CDHU, 2007)

2. A implantação de praças de uso público local, dada a inexistência de espaços livres destinados a lazer e socialização. 

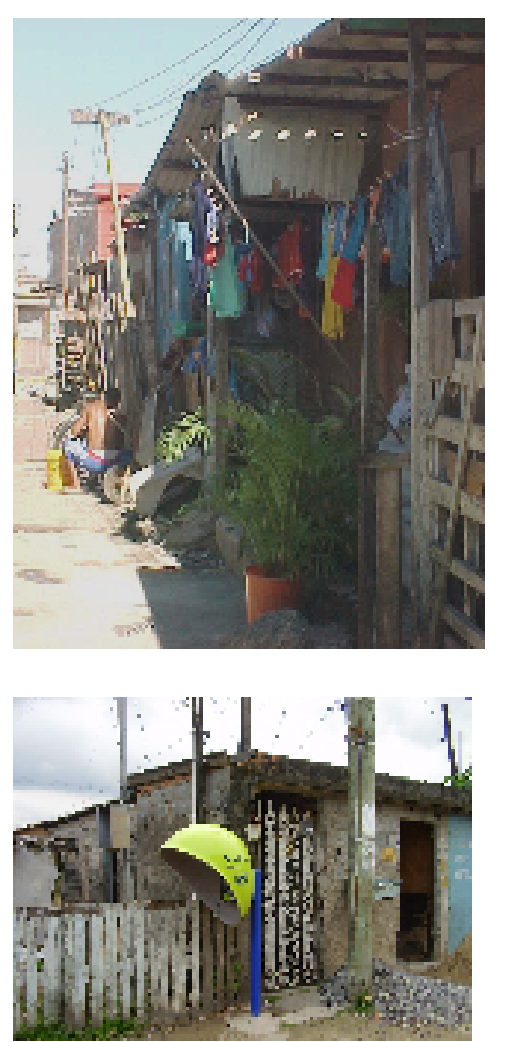

Fig. 111 e 112 - Setor 1, Favela México $70(\mathrm{CDHU}, 2007)$

\section{A implantação de edifícios residenciais em bolsões que apresentavam grande} concentração de moradias abaixo do nível do grade final das vias ou moradias de madeira e alvenaria em estado precário e que urbanisticamente constituíssem pontos de interesse para todo o conjunto construído do Setor de Urbanização.

Essas novas implantações seriam feitas com a tipologia utilizada no conjunto São Vicente F4, então em obras, desenvolvida em três pavimentos, cada um dos quais com quatro apartamentos de dois dormitórios. Com isso, em cada um dos bolsões propostos, seria possível, além das moradias, implantarem praças lineares ao longo das calçadas e praças em esquinas de grande confluência de moradores, aumentado o espaço público de lazer e socialização e propiciando arborização pública, já que, devido ao projeto de drenagem e às calçadas estreitas, em várias vias essa arborização não seria viável, sendo apenas possível o plantio de vegetação baixa em jardineiras.

A escolha do edifício vertical, além dos motivos apontados acima, se dava pelas condições do solo no local, resultante de sucessivos aterros, requerendo grande investimento em fundações, custo que se justificaria no caso de verticalização, pelo conseqüente adensamento. $O$ uso de unidades individuais (térreas ou assobradadas) com construção pela CDHU era inviabilizado pelas condições do solo e pelo alto custo. 


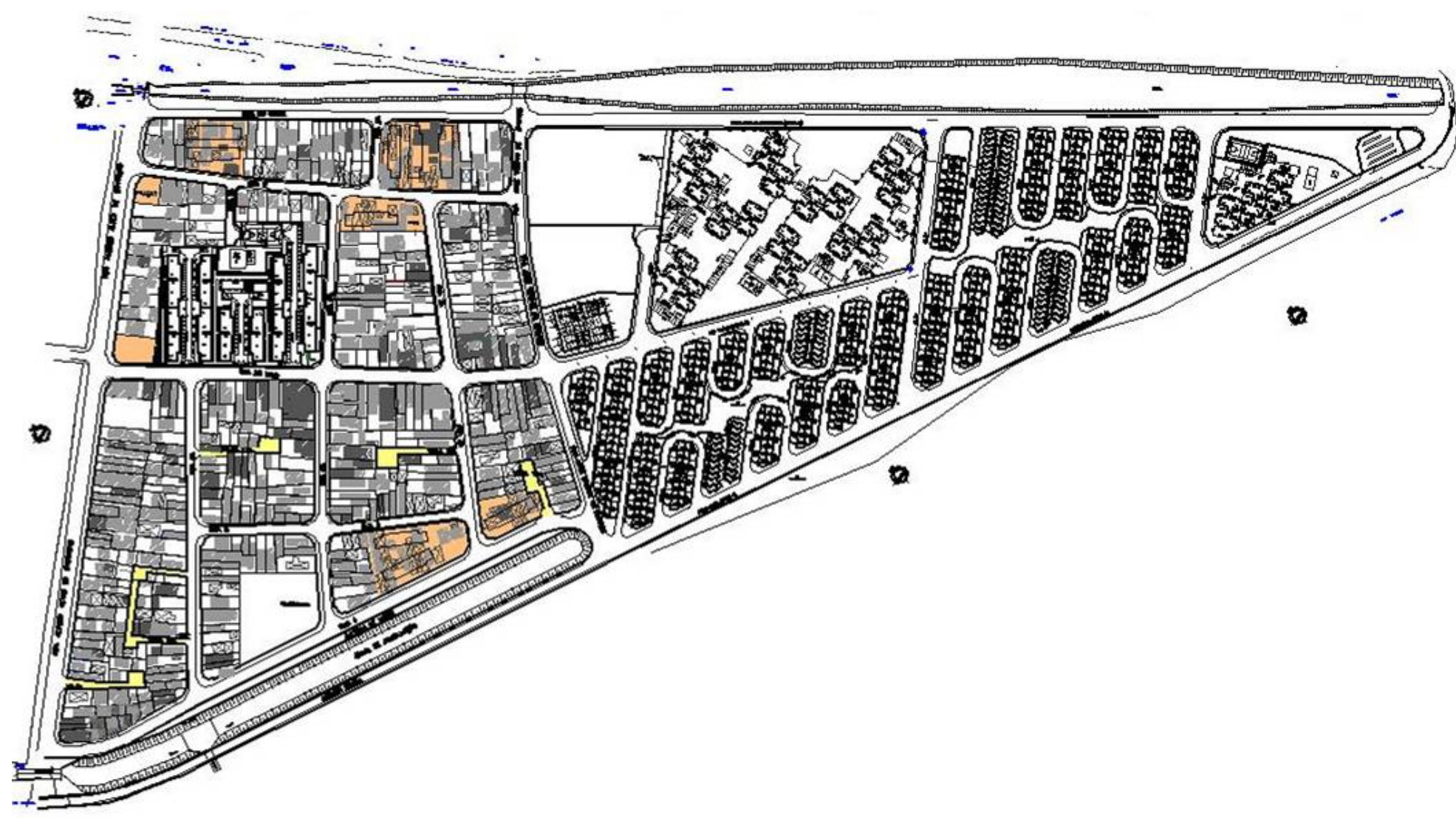

Fig. 113 - Projeto da totalidade da intervenção. Setor de Urbanização e Setor de Reassentamento,

Favela México 70 (CDHU, 2007) 

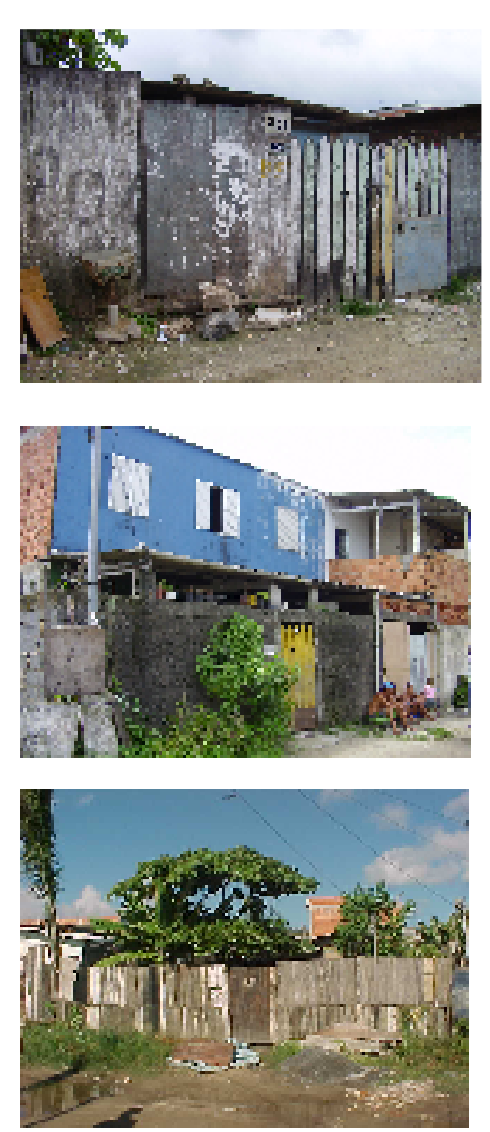

Fig. 114,115 e 116 - Setor 1 , Favela México 70 (CDHU, 2007)
O projeto de urbanização procurava manter a dinâmica local; organizar fisicamente os fluxos internos; possibilitar a construção de moradias mínimas pela população; equipar a área com espaços de uso público dos moradores; possibilitar no futuro, quando da regularização fundiária, a definição física clara e irrefutável dos lotes urbanos; introduzir de forma dispersa uma nova maneira de habitabilidade que tivesse a capacidade de "contaminar" o entorno, melhorando a qualidade das demais edificações; qualificar o espaço da rua, valorizando seus potenciais urbanísticos; dar condições urbanas básicas de permanência e crescimento da população ali instalada; e organizar o espaço urbano a partir da habitação existente, sem perder a noção do conjunto. $\mathrm{O}$ projeto propunha - dada a impossibilidade de se atuar individualmente em cada caso - que os moradores recebessem orientação de técnicos na área de edificações para melhoria construtiva de suas moradias, com ênfase nas questões sanitárias, de ventilação e de iluminação interna.

Cabem aqui algumas observações colhidas após a finalização dos trabalhos de projeto.

O projeto, desenvolvido em cinco meses, de março de 2007 a julho de 2007, levou em conta os aspectos fornecidos pela realidade, para o que as visitas ao local feitas pela equipe de projeto em conjunto com a equipe social, foram de fundamental importância. Mesmo com esse contato direto com os moradores, as propostas foram primeiro formuladas para depois serem a eles apresentadas. 
A responsabilidade técnica dos projetistas foi rigorosamente observada e a boa prática de projeto não foi em nenhum momento impedida pela realidade precária encontrada.

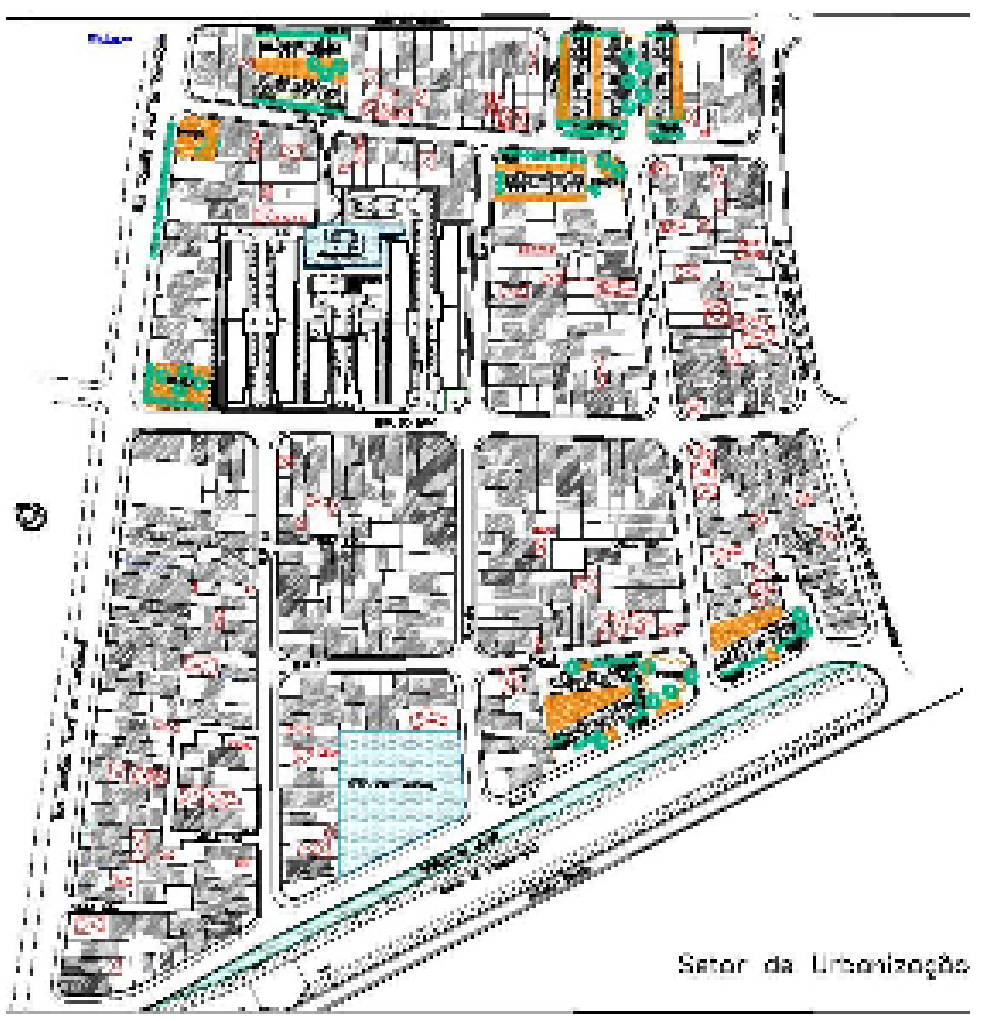

Fig. 119 - Projeto do Setor de Urbanização, Favela México 70 (CDHU, 2007) 

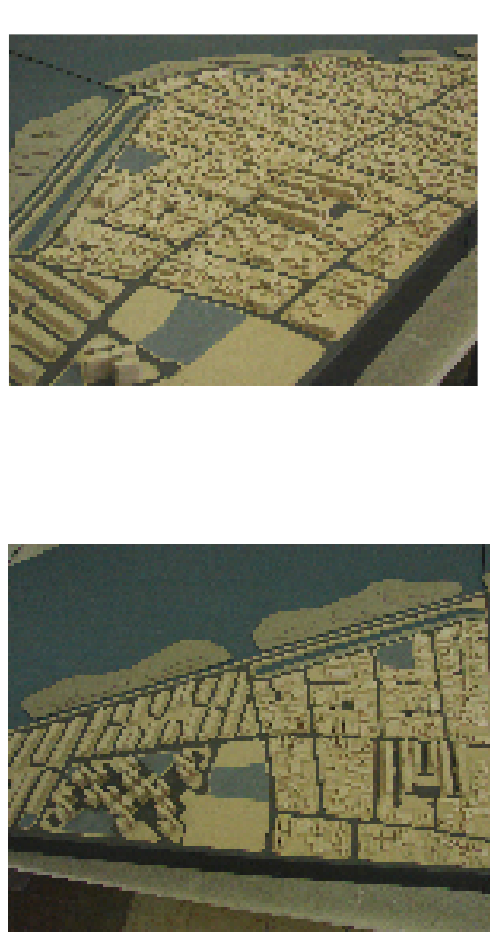

Fig. 120 e 121 - Projeto México 70 (PMSV, 2008)
Não foi possível nessa experiência estabelecer uma aproximação "científica" a essa realidade urbana. Os critérios de projeto foram determinados por parâmetros mínimos de boas condições físicas de habitabilidade, mas sem que se impusesse algum modelo urbanístico teórico que obrigasse a população a adaptar-se a outro modo de vida. Ao contrário, buscou-se constatar a dinâmica e as deficiências existentes para então definir propostas.

Uma das maiores carências do projeto foi encontrada no âmbito das edificações. Ainda que urbanisticamente o resultado pudesse alcançar boa qualidade espacial, a impossibilidade de intervenção direta nas moradias restringia em muito o sucesso global da intervenção.

Convém aqui deter-se um pouco na forma da habitação. Ainda que de madeira, várias das casas apresentavam plantas bem agenciadas e construções bem implantadas. Mesmo em locais em que havia mais áreas livres externas, a moradia se restringia à casa propriamente dita, não havendo apropriação dos espaços externos pelos moradores. Uma feição rural, que se poderia esperar que estivesse embutida no agenciamento, não foi constatada. O que existia era uma grande precariedade incrustada em uma vida absolutamente urbana.

Para dar prosseguimento à metodologia desenvolvida seria necessária uma maior intervenção na massa construída. Não nos parecia que as alternativas até agora utilizadas de mutirão, autoconstrução e intervenções similares poderiam ter o alcance exigido para esse tipo de intervenção. No caso da favela México 70 as famílias eram cerca 800 (650 das quais permaneceram no local), mas há no Brasil áreas com cerca de 8.000 famílias.

Acrescenta-se à metodologia a possibilidade de projetos pontuais e diversificados de edificações habitacionais, obviamente dentro de critérios de economia e eficiência. 

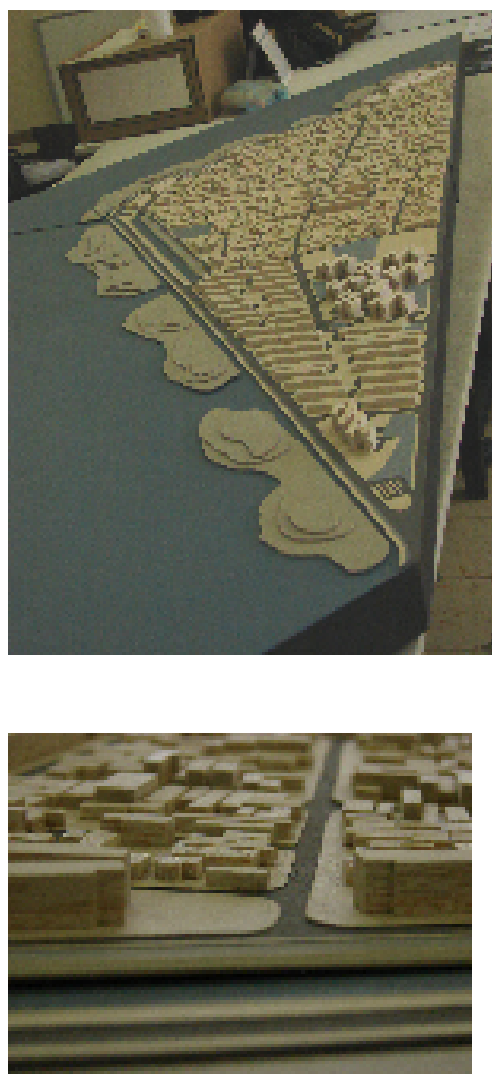

Fig. 117 e 118 - Projeto México 70 (PMSV, 2008)

O desenvolvimento de tecnologias de ponta para projeto e construção é de fundamental importância para o sucesso de tais intervenções. Caberia ao setor de edificações associar-se ao de urbanismo para encontrar soluções pertinentes para as diferentes situações encontradas no contato com a realidade.

No caso do projeto México 70, o uso de uma tipologia em lâmina, compacta, sem a necessidade de muitos equipamentos externos de apoio, possibilitou uma implantação "urbana" das unidades na malha existente, sem que se criassem condomínios de grandes dimensões (até 200 unidades, como número máximo de unidades em cada um).

A elaboração de tipologias a partir de uma configuração real, e não o desenvolvimento de um modelo ideal seria um dos mais importantes passos para se ulterior desenvolvimento da metodologia utilizada. 


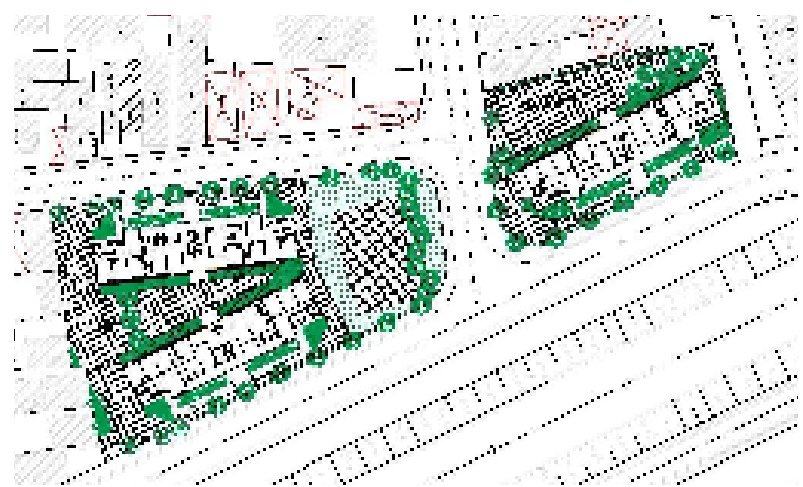

Fig. 120 - Projeto do Setor 2 de Urbanização. Implantação nos bolsões 4 e 5. Favela México 70 (CDHU, 2007)

Este exemplo demonstra que uma maior liberdade projetual e revisão de conceitos urbanísticos permitem alcançar resultados de melhor qualidade e eficiência. Apenas o tempo, porém, poderá revelar os acertos e erros da experiência.

Ao Estado cabe conceder essa liberdade, uma vez que a liberdade permitida exclusivamente pelo mercado se expressa mais pelas possibilidades financeiras dos investidores que por experiências pioneiras do ponto de vista urbano e arquitetônico.

O projeto será implantado em sua quase totalidade. Há um problema fundiário no local que impede uma ação mais incisiva da CDHU sobre a terra. Após 30 anos de descuido, o poder público não é capaz de intervir diretamente no conjunto de habitações, a não ser que tenha argumentos técnicos, como os de instalação de redes. Moradores de residências construídas inteiramente de alvenaria e concreto, acabadas e de maiores dimensões, se recusaram, e com razão, a deixar suas 


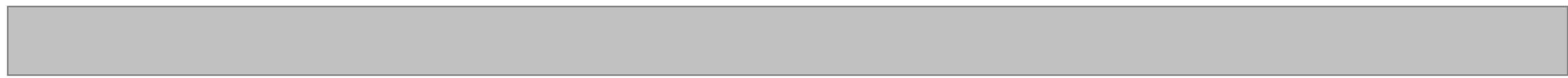

casas em troca de apartamentos de dois dormitórios, pelo qual, ademais, deveriam pagar -

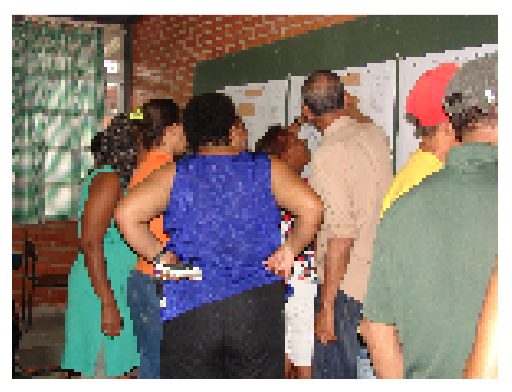

embora as despesas não se limitem a essa, já que uma vez instaladas as redes, os moradores terão contas de água, esgoto, lixo e outras a saldar mensalmente.

Essa experiência, dentro do contexto de financiamentos e políticas públicas, revelou que a precariedade é o que define as periferias metropolitanas, e não exatamente a forma de sua ocupação. A informalidade, ainda que seja um aspecto importante, não teve, ao menos neste caso, interferência direta no espaço e na acomodação das moradias.

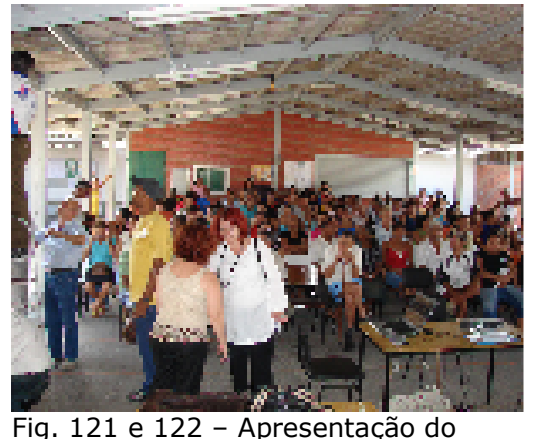
México 70 (CDHU, 2007) 
A grande expansão das grandes regiões metropolitanas no Brasil, e não apenas na de São Paulo, se dá nas áreas periféricas.

Nestes anos finais da primeira década do século XXI, as favelas, ao menos as das regiões metropolitanas paulistas, não se configuram mais como aglomerados de papelão, chapas metálicas e plástico. Muitas delas são assentamentos consolidados, autoconstruídos e, muitas vezes, organizados. Ao que parece, mais cedo ou mais tarde o poder público virá a urbanizá-las.

'Favela' passa a ser quase um termo jurídico, já que o que a distingue dos assentamentos formais e autoconstruídos é, além da falta de infra-estrutura, a ilegalidade da terra. Embora o poder público tenha obtido algum êxito na instalação de infra-estrutura, o que se vê nas periferias paulistanas não é propriamente o que se poderia chamar de 'cidade', no sentido tradicional da palavra.

A urbanização de áreas degradadas, sejam elas legalizadas ou não, requer, além de todos os instrumentais até agora desenvolvidos, uma metodologia de projeto que permita intervir nessas áreas e dar-Ihes um caráter realmente urbano.

A urbanização de favelas periféricas, como expõe esta pesquisa, leva a um aumento de valor da terra, o que, se de um lado pode expulsar os mais pobres, de outro permite a essas áreas se conectarem à malha existente e se requalificarem.

A formação das favelas, como assentamentos precários, é de ordem estrutural. A urbanização de favelas não ataca a pobreza urbana em sua estrutura, como comenta Davis (2006), problema que não se reduz frente à dinâmica de crescimento atual que, vinculada a ao 
desenvolvimento da tecnologia e de atividades do setor terciário, aumenta o desemprego segundo Toledo(2000).

As características cada vez mais permanentes das favelas a partir dos anos 1990, principalmente com a urbanização sanitarista, levaram à seguinte situação no município de Santo André, na Região Metropolitana de São Paulo:

"Em 1999, 69\% do total de moradias construídas em favelas eram de alvenaria; nos núcleos considerados urbanizados, o percentual subia para $92,8 \%$ e nos núcleos sem intervenção (não urbanizados) caía para $61,1 \%$. Aproximadamente $76,2 \%$ do total de moradias nas favelas eram constituídos de um pavimento, $22,5 \%$ de dois pavimentos e $1,3 \%$ de três, e do total de núcleos urbanizados, 56,7\%, 38,9\% e 4,3\% apresentavam um, dois e três pavimentos, respectivamente. Os 'lotes' de $78,8 \%$ do total dos núcleos e $72,6 \%$ dos urbanizados abrigavam uma única moradia; $14,6 \%$ (total) e 19,2\% (urbanizados) abrigavam duas moradias e 5,9\% e 7,8\%, três moradias, respectivamente. Lembremos que, nos núcleos urbanizados, os lotes definidos pelo plano de urbanização apresentam em média $50 \mathrm{~m}^{2}$. Nos núcleos urbanizados de Santo André, vem crescendo a verticalização de lotes de tamanho reduzido, que passam a abrigar mais de uma moradia e família. A densidade media das favelas é de 550,21 hab./ha O fenômeno acompanha a tendência, encontrada nas cidades, de os lotes legais acomodarem mais de uma família ou domicílio. Em 2001, nos municípios de Santo André, São Caetano e São Bernardo, a média de domicílios por lote 'unifamiliar' era de 1,6. No município de Diadema, em 1995, a média (mediana) era de duas famílias por lote ou terreno; apenas $45,5 \%$ dos lotes ou terrenos eram ocupados por apenas uma família e cerca de 32\% eram ocupados por três famílias ou mais." (DENALDI, 2003, p. 145)

Seria um desperdício de recursos que essa realidade não fosse tratada em sua totalidade. 
Os problemas que se colocam, guardadas as devidas proporções e tendo-se em mente as especificidades econômicas da população e do Estado no Brasil, se assemelham àqueles enfrentados por países que recuperaram porções degradadas de seus territórios urbanos, com forte enfoque nas questões habitacionais.

Se considerada a possibilidade de recuperação de parte da massa autoconstruída na periferia das regiões metropolitanas, o déficit habitacional possivelmente diminuiria de modo considerável. Um plano de ação ainda mais amplo, com recuperação de edificações existentes e construção de novas moradias, dentro de um plano urbanístico que fosse capaz de construir cidade, a recuperação e inserção social dessas áreas seria ainda mais provável.

A experiência de projeto de urbanização na Favela México 70 permite desenhar o quadro exposto a seguir.

Do ponto de vista de projeto, são ao menos dois os estágios de intervenção nos projetos de urbanização de favelas:

1. a recuperação ambiental da área, através da instalação de infra-estrutura de saneamento básico, coleta de lixo, drenagem, iluminação e pavimentação, o que onera os moradores com taxas de uso dos serviços públicos e impostos;

2. a recuperação das moradias, a encargo dos moradores, que não recebem nenhuma orientação.

Há remoções de moradias para a instalação, manutenção e operação desses serviços.

O que se verificou no Projeto do México 70 é que o processo de intervenção poderia se dar da seguinte forma: 
1. requalificação urbana do bairro com projeto de desenho urbano, levando-se em conta primeiramente os usos (residências, comércio, serviços, equipamentos comunitários públicos e privados, transporte público, previsão ou não de expansão). A infra-estrutura e todos esses serviços seriam parte desse projeto. A recuperação ambiental e de moradias seria prevista em uma única etapa de projeto, para implantação futura.

2. As remoções de moradias se dariam em função da totalidade do projeto e incluiriam a construção de novas unidades na área com o intuito de manter a densidade populacional compatível com todos os serviços e instalações propostas em projeto.

3. A reforma das edificações remanescentes se daria de forma conjunta, após minucioso levantamento.

4. Deveriam ser elaborados e previstos instrumentos para a intervenção (legislação específica, normatizações necessárias, aporte de verbas, subsídios etc.)

5. A locação social deveria ser um item a ser considerado. Uma vez que grande parte das moradias nesses assentamentos é alugada, o Estado deveria ser detentor (proprietário) de uma grande parte dos imóveis para fins de locação de interesse social, evitando-se o excesso de especulação imobiliária que a princípio já existe, a despeito das condições precárias das favelas. Como expõe Davis (2006, p. 88), "a concessão de títulos de propriedade, em outras palavras, acelera a diferenciação social na favela e nada faz para ajudar os locatários, verdadeira maioria dentre os pobres de muitas cidades".

Em São Paulo, segundo DAVIS (2006, p. 89), que cita Taschner: 
"[...] com as melhorias o submercado imobiliário se consolida na favela. Terrenos e casas tornam-se bens de consumo e o preço dispara'. Um dos resultados é o surgimento do que Taschner chama de 'favela dentro da favela', quando as casas dos invasores são substituídas por cortiços mal construídos, onde se alugam quartos aos mais pobres dentre os pobres. Em outras palavras, sem intervenção pública decisiva no mercado imobiliário, a mera distribuição de títulos de propriedade dificilmente seria uma alavanca de Arquimedes para erguer o destino da grande massa de moradores urbanos pobres".

A partir desse enfoque, se poderiam aprofundar os estudos sobre as periferias, uma vez que, do ponto de vista de projeto, não existiriam grandes diferenças entre favelas e outros assentamentos precários - que podem inclusive ser conjuntos habitacionais construídos pelo Estado e em condições de degradação, invadidos ou que fazem parte de bairros periféricos.

Alguns critérios urbanísticos poderiam ser aplicados com o intuito de consolidar essas ocupações de forma que possam ser mantidas, criando-se uma dinâmica própria de boa qualidade urbana.

López de Lucio (2007) aponta algumas direções para dinamizar as periferias e integrá-las de forma mais sustentável à malha urbana existente:

1. adensar e compactar os tecidos urbanos;

2. incluir atividades complementares (complexidade funcional);

3. aplicar o conceito de cidade residencial aberta, evitando-se os grandes condomínios ou o excesso de áreas livres e acessos privados;

4. estabelecer uma sustentabilidade funcional (na vida cotidiana); 
5. estabelecer uma sustentabilidade social (articulação de retículas contínuas e espaços públicos livres);

6. priorizar o transporte público, o uso de bicicletas e os deslocamentos de pedestres (nos dois últimos casos estabelecendo parâmetros de proximidade entre as zonas de serviços e lazer e as zonas residenciais);

7. considerar a diversidade dos perfis familiares, propondo diversas tipologias (residência unifamiliar compacta, apartamentos de dois e três dormitórios, habitações coletivas e residências unifamiliares);

8. considerar as atividades de trabalho domiciliares ${ }^{34}$;

9. prever espaços e atividades para o tempo livre das diversas faixas etárias;

10. propiciar, no espaço público, o contato social;

11. prever unidades construídas de trabalho terciário (comércio/serviços, equipamentos públicos e privados) - de $6 \%$ a $15 \%$ do total da área lucrativa da atuação;

12. procurar a complexidade tipológica e dimensional no programa residencial;

13. promover dinamismo nos espaços públicos (comércio de proximidade nas ruas).

Alguns índices para dimensionamento da intervenção também seriam muito úteis no caso dos projetos de urbanização de grandes favelas:

${ }^{34}$ Ver Capítulo 3 de Perfil de necessidades e projeto de habitação: um estudo de métodos, de P. J. A. Amaral (tese de doutorado, São Paulo: FAUUSP, 2005). 
1. densidade residencial bruta (soma do número de habitantes com o de empregos localizados dividida por unidade de superfície);

2. densidade mínima de 50 a 55 unidades habitacionais por hectare (UH/ha);

3. densidade média de 200 a $220 \mathrm{UH} / \mathrm{ha}$;

4. nós de urbanidade: 75 a $85 \mathrm{UH} / \mathrm{ha}$;

5. densidade máxima de 300 a $340 \mathrm{UH} / \mathrm{ha}$.

Em resumo, López de Lucio (2007) propõe que no programa sejam definidos o uso do solo, a densidade da ocupação (em UH/ha e hab./ha), a concentração de atividades mistas, transporte público, zonas verdes, áreas desportivas, localizações tangenciais e periféricas de grandes equipamentos (hospitais, universidades), dimensionamento das vias conforme uso (de 8 a $35 \mathrm{~m}$ ), dimensionamento de áreas verdes (para o que propõe $18 \mathrm{~m}^{2} / \mathrm{UH}$ ) e tamanho das quadras para que não haja excesso de vias de circulação nem minicondomínios fechados (de 10000 a $20000 \mathrm{~m}^{2}$ ) 35 .

A situação econômica do país tende a ser tomada como justificativa para que as intervenções destinadas à população de baixa renda sejam débeis, por deverem ser barateadas. Tal escolha tem decorrências:

"Los procesos de marginalización/exclusión de segmentos de la población (dualización social) señalan una tendencia, difícil de atajar desde las técnicas del diseño urbano y la arquitectura, hacia las urbanizaciones cerradas [...] y la especialización/privatización [...] del espacio público. La importancia que han cobrado estas fórmulas en países muy dualizados, como los Estados Unidos de

${ }^{35}$ Para maior aprofundamento, ver Construir ciudad en la periferia, de R. López Lucio (Madrid: Mairea Libros, 2007). 


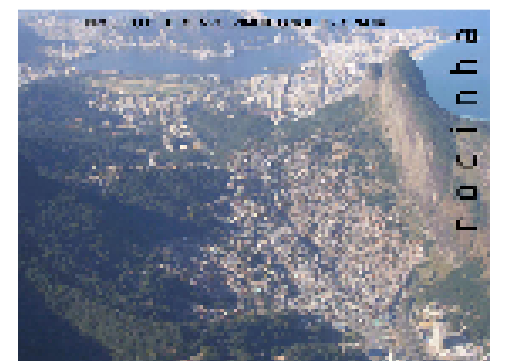

Fig. 121 - Rocinha. Rio de Janeiro (JAUREGUI).

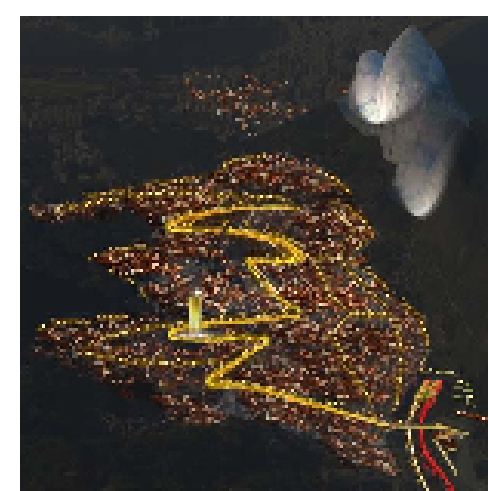

Fig. 122 - Rocinha, Rio de Janeiro - Perspectiva da intervenção (JAUREGUI).
América, algunas repúblicas suramericanas o Sudáfrica, dan testimonio de la extensión e intensidad del problema.

En la experiencia destructiva de noviembre 2005 en las periferias de muchas ciudades francesas se han conjugado, sin duba, problemas de marginalidad en las localizaciones espaciales de los barrios afectados y errores de diseño (en particular, inflación y falta de significación/apropiación real de los espacios libres públicos [...]), pero también situaciones de precariedad económica y anomia social agravadas: paro juvenil, recortes en los programas de reinserción y capacitación profesional, precariedad laboral, ausencia de perspectivas a medio plazo ${ }^{36}$, etc. Es frente a estos problemas cuando las herramientas y las posibilidades del diseño residencial y urbano se ven inermes. No obstante podrían contribuir cuando menos a no agravar tales problemas económicos y sociales de índole estructural. El conjunto de criterios y recomendaciones que se han descrito en páginas anteriores intenta transitar en esa dirección, reconociendo las dificultades que entraña." (LÓPEZ DE LUCIO, 2006, p. 86) [grifos nossos]

O processo de urbanização de favelas entendido em primeira instância como requalificação urbana resulta de aproximações e análises diversas daquelas obtidas quando se tomam como premissas iniciais a provisão de infra-estrutura básica e a regularização fundiária.

Jorge Mario Jáuregui, arquiteto e urbanista argentino que trabalha no Brasil há três décadas e tem grande experiência na urbanização de favelas no Rio de Janeiro, aponta que os projetos de

${ }^{36}$ Sobre o mundo dessas comunidades, ver a experiência de Brasilândia, na cidade de São Paulo, em Paisagens reveladas no cotidiano da periferia: distrito de Brasilândia, Zona Norte do município de São Paulo, de C.M.M.M. Angileli (dissertação de Mestrado, FAUUSP, São Paulo, 2007), disponível em http://www.jauregui.arq.br/entrevistas.html\#03. 
requalificação urbana de áreas informais já fazem parte do repertório da arquitetura e do urbanismo:

"É evidente que [...] repensemos os nossos conceitos de arquitectura, num sentido menos autoreferenciado, num sentido muito mais sensivel às condições e ao contexto em que se insere o objecto arquitectónico, contexto entendido como ambiental-social; as condições físicas num determinado contexto social. Portanto, uma arquitectura capaz de relacionar, de ser sensivel, de incluir as particularidades tanto do meio físico quanto da ocupação social desse meio físico, da implantação, da instalação de uma sociedade num território com o qual estabelece uma série de interacções, muitas vezes, devemos dizê-lo, interações claramente negativas. A partir da Modernidade, com o aparelho tecnológico em permanente expansão o homem tem cada vez mais possibilidades de interferência, e as usa no sentido de cada vez mais comprometer o meio natural.

Então o que se pretende hoje é que a inteligência volte a dominar as acções humanas, e a arquitectura como parte dessa inteligência seja capaz de ser mais interactiva. Por um lado, recolhendo conhecimentos tradicionais, ancestrais, decantados ao longo dos séculos e esquecidos na modernidade. Hoje volta a se pôr no tapete os condicionamentos climatéricos, a utilização de técnicas, imagens e valores que tenham a ver com a forma com que o homem tradicionalmente se instalou no meio ambiente; a necessidade não só de se proteger da chuva, do calor, dos ventos, das condições materiais, mas também a de agrupar os edifícios fazendo com que sejam mais, ou menos, inclusivistas dos outros homens; mais, ou menos, consideradores do meio ambiente.

Sabemos que a arquitectura pode ser feita tanto para Reis quanto para Plebeus, porém, quer-se uma arquitectura que sirva para todos, para qualquer cidadão, pois o cidadão é o que tem plenos direitos no território em que habita. Isto significa que a arquitectura a que devemos apontar, considerar, redefinir e fazer, terá de ser sensível ao seu contexto físico e social, transmitindo a estética da nossa 
época, dialogando com a estética do passado ao mesmo tempo que não implique uma ruptura, pois temos que acabar com esse pensamento de que cada nova tendência tem de significar uma ruptura; pelo contrário, cada busca deve cada vez mais restabelecer a relação com o passado, sob novas bases. 137

No Rio de Janeiro, algumas experiências já contam com um tipo de intervenção com um foco de recuperação urbana e a metodologia que está se desenvolvendo muito pode enriquecer as experiências paulistas.

${ }^{37}$ Entrevista a Henrique dos Santos. Arquiteto Rio-Angola 2004-2005. 
Os processos de projetos de urbanização de favelas estão em desenvolvimento. Para tanto, uma metodologia de pesquisa que se preocupe em sistematizá-los e a partir deles criar alguma teoria de projeto deve ser desenvolvida.

Uma vez enfrentada a primeira etapa da miséria absoluta, a recuperação de áreas que serão mantidas requer um grande esforço. Por seu caráter complexo, multidisciplinar, volátil, sujeito a mudanças bruscas na esfera pública e econômica, são necessárias analogias com outros campos da ciência, em constante desenvolvimento.

Essa pesquisa, uma vez iniciada a partir de um problema concreto, de obras a serem contratadas e executadas, de uma população existente e de uma demanda real, possibilita, de forma qualitativa, propiciar, futuramente, um questionamento mais profundo a cerca de critérios, parâmetros e escolhas projetuais para a intervenção em favelas. 
A partir da lógica da produção habitacional por vários agentes, exposta por Ball (1986), analisar a produção de habitação da cidade de São Paulo de forma integrada deu bases para o entendimento do fenômeno da favela como parte dessa mesma produção.

A precariedade, geradora do fenômeno, criou a necessidade de se debruçar sobre a mesma e diminuí-la através da inclusão social, física e cultural da comunidade - e de sua área - na cidade como um todo.

O primeiro passo para isso é a aceitação da favela, não apenas como fenômeno social, mas como realidade física, carregada de sentido. Os estudos sociais apresentados nesta dissertação mostram como a comunidade favelada já se encontra inserida na sociedade, ainda que novas atualizações devam ser feitas, como a de Janice Perlman - The Metamorphosysis of Marginality:

the favelas of Rio de Janeiro: 1969-2002, estudo realizado com o apoio do Banco Mundial. Essa inserção é mais uma prova da exigência de interferência física sobre as áreas precárias.

Do ponto de vista do projeto urbanístico - e da contribuição que os profissionais da área, especialmente os arquitetos, podem dar - o desenvolvimento de uma metodologia de projeto de urbanização de favelas é fundamental para a real integração.

Além de se tratar de um ambiente bastante complexo, a metodologia desenvolvida para intervenção em favela deve estar passo a passo com as transformações da sociedade contemporânea, incluindo aí os avanços tecnológicos e científicos.

O período de inovação tecnológica, segundo McLuhan, reflete na visão de mundo dos indivíduos, pois são extensão do seu corpo, e "precisamente en el momento en que um nuevo medio que induce um ambiente aparece y transforma nuestro equilibrio sensitivo, tambien resulta invisible." (McLUHAN, 
1998 p. 284) Por isso sua compreensão com os habituais instrumentos de observação não são eficazes.

Segundo McLuhan (1998) "Cualquier acercamiento a los problemas ambientales debe ser suficientemente flexible y adaptable para abarcar la matriz ambiental completa, la cual está em constante flujo." (p. 283)

Esse entendimento do ambiente não apenas do ponto de vista físico e social, mas cultural, é fundamental para projetos de urbanização de assentamentos existentes, onde uma dada comunidade já produziu seus sentidos e sua cultura inclusive através de suporte físico e alteração do espaço. O conceito de Capital Social apresentado por De La Noce (2008) contribui para suportar essas análises.

O projeto de urbanização da favela México 70, onde por três meses todas as moradias da área de urbanização foram visitadas uma a uma pela equipe de projeto, possibilitou uma experiência prática e uma vivência pela equipe que poderiam ter sido interpretadas e traduzidas em propostas projetuais mais do que de fato o foram. As propostas projetuais foram limitadas porque as diretrizes impostas pela Companhia (CDHU) restringiam a intervenção em alguns elementos como infraestrutura básica, naquele primeiro momento.

A rapidez e eficiência dessa análise talvez tenha se dado pelo fato do projeto de arquitetura e urbanismo ter uma relação estreita com a arte: "Hasta la presenta era, (esta) conciencia ha estado siempre reflejada primero por el artista, que há tenido el poder y el coraje del vidente para leer el lenguaje del mundo exterior y relacionarlo com el interior" (McLUHAN, 1998 p. 285) 
O desenvolvimento do processo de projeto de urbanização de favela deve levar em consideração aspectos relacionados a produção em si dos projetos e a forma simultânea de desenvolvê-los entre as diversas disciplinas, com base nas mais modernas técnicas de projeto, onde há diversas linhas de pesquisa elaboradas.(FABRICIO, 2002 P. 34$)^{38}$

Mas, além disso, devem-se incorporar na metodologia de projetos para recuperação dessas favelas os sentidos sociais e culturais construídos pelo capital social incorporado a elas.

Abarcar toda essa gama de conhecimento não é possível em uma única disciplina, nem a Arquitetura nem o Urbanismo sozinhos teriam essa capacidade, mas deve se refletir no processo de projeto urbanístico, e para isso novos instrumentais e análises projetuais devem ser desenvolvidos.

Este trabalho procurou iniciar esse processo através de um maior entendimento do fenômeno favelas, sem deixar de lado os aspectos do projeto físico, que se pretendem estudar em profundidade numa pesquisa posterior.

A metodologia de projeto desenvolvida ao longo do processo em curso deve ser capaz de abarcar uma série de determinantes:

- aspectos quantitativos de número de atendimentos;

- aspectos de eficiência urbana da infra-estrutura básica;

- aspectos de economia na implantação dos projetos;

- aspectos de economia na manutenção dos espaços construídos;

- aspectos de inserção urbana através de equipamentos institucionais e públicos;

${ }^{38}$ Ver FABRICIO, M.M. Projeto Simultâneo na Construção de Edifícios. Tese (Doutorado) - São Paulo: Escola Politécnica. Universidade de São Paulo, 2002 
- aspectos de inserção cultural e social

Esses seriam alguns dos aspectos a serem levados em consideração no projeto de urbanização de uma favela.

Além desses, outro deveria ser levado em consideração como um dos principais: o espaço doméstico.

Os atuais processos de projeto de urbanização de favelas não levam em consideração a célula habitacional.

Se a favela contém em si como principal característica a precariedade, a habitação para o favelado ainda tem como principal função a proteção: "Se a roupa é uma extensão da pele para guardar e distribuir nosso próprio calor e energia, a habitação é um meio coletivo de atingir o mesmo fim - para a família ou um grupo." (McLUHAN, 1964 p. 144)

Mas essa habitação precária, como já foi visto, se encontra inserida em uma estrutura urbana e com ela interage ativamente. Os avanços tecnológicos e sociais, portanto, afetam os favelados do mesmo modo que afetam os não favelados. "... depois de mais de um século de tecnologia elétrica, (isso sem contar os avanços da era eletrônica) projetamos nosso próprio sistema nervoso central num abraço global, abolindo tempo e espaço...." (McLUHAN, 1964 p. 17) E por isso, não apenas o projeto de urbanização de favela deve abarcar as mais modernas técnicas de projeto como também a intervenção da moradia.

O Estado, principal agente coordenador de todo o processo de urbanização de favela, ainda não assumiu para si a responsabilidade pela célula habitacional, ora por motivos econômicos, hora por falta de instrumental de projeto. 
A diversidade das famílias em uma favela em número e necessidades, com uma constante mudança da própria célula habitacional, é um dos aspectos que também devem ser incorporados nessa metodologia, exigindo processos não apenas simultâneos de projeto, mas abertos, como enfatiza Turner (1972) p.155.

Na visão de McLuhan, 1964, teórico da comunicação e educador canadense (21/7/191131/12/1980), introdutor do conceito de 'aldeia global', "A engenharia moderna pode produzir meios habitacionais que vão desde a cápsula espacial até paredes formadas por jatos de ar. Algumas firmas se estão especializando em grandes construções com paredes e pisos removíveis. É uma flexibilidade que tende naturalmente ao orgânico. A sensitividade humana parece uma vez mais harmonizar-se com as correntes universais que fizeram do homem tribal um mergulhador cósmico". (McLUHAN, 1964 p. 149)

Pensar nos processo de intervenção de urbanização de favelas, como foi exposto, deve passar pela revisão das metodologias de projeto arquitetônico. A precariedade deve ser levada em conta como um dos elementos do projeto, mas não como um obstáculo. O padrão urbano resultante deve ser sim diferenciado, mas não pela precariedade, e sim pela criatividade.

Mas como último resultado, deve-se pensar o espaço doméstico, o espaço de acolhimento, o interior da casa, a célula construída e segura, o abrigo que representa uma moradia. 
1. ABIKO, A. K. Coordenação K. Estudos estratégicos de apoio às políticas urbanas para os grupos de baixa renda no Brasil: análise de habitação informal e avaliação de programas de urbanização de favelas - Urbanização de Favelas - Infra-estrutura Urbana em Áreas Informais - CD1 - DOC10.pdf - Cities Alliance/Banco Mundial, 2005.

2. ABIKO, A.K. O papel do Estado na Habitação. Disponível em http://www.arcoweb.com.br/entrevista/entrevista36.asp. Acesso em 3/02/2009

3. ABNT - NBR $6023-2002$

4. $\quad$ ABNT - NBR $10520-2002$

5. AMARAL, P.J.A. Perfil de necessidades e projeto de habitação: um estudo de métodos. Tese (Doutorado) São Paulo: FAUUSP, 2005

6. ANGILeli, C. M. M. M. Paisagens Reveladas no Cotidiano da Periferia: Distrito de Brasilândia Zona Norte do Município de São Paulo Dissertação (Mestrado) São Paulo: FAUUSP, 2007

7. BALL, M. "Housing analysis: time for a theorical refocus", Housing Studies London, v.1, n.3, 1983

8. BANHAM, R. Theory and design in the First Machine Age. London: The Architectural Press, 1960. 
9. BAYEUX, G.; FRANÇA, E. Favelas upgrading: a cidade como integração dos bairros e espalo de habitação. Arquitextos, n. 27, ago. 2002. Disponível em: http://www.vitruvius.com.br/arquitextos/arq027/arq027_00.asp. Acesso em: 4/12/2008

10. BENEVOLO, L. Historia de la arquitectura moderna. Barcelona: Gustavo Gili, 1994

11. BENEVOLO, L. The origins of modern town planning. London: Routledge \& Kegan Paul, 1967

12. BLANCO, C.Jr. As transformações nas políticas habitacionais brasileiras nos anos 1990: o caso do Programa Integrado de Inclusão Social da Prefeitura de Santo André. Dissertação (Mestrado). São Paulo: Escola de Engenharia de São Carlos - USP, 2006

13. BONDUKI, N. Origens da Habitação Social no Brasil. São Paulo: Est. Liberdade/FAPESP, 1998

14. BRUNO, E. S. História e Tradições da Cidade de São Paulo. $2^{a}$ ed., 3 vols Rio de Janeiro: José Olympio, 1954

15. BUENO, L.M.M. Projeto e favela: metodologia para projetos de urbanização Tese (Doutorado) São Paulo: FAUUSP, 2000

16. CAMINOS, H e GOETHERT, R. Urbanization Primer Cambridge, Massachusetts and London, England: The MIT Press, 1976

17. CARVALHO, E.M.B O vão entre a cidade fática e a cidade legal: o processo de regularização fundiária em São Paulo. Dissertação (Mestrado) São Paulo: FAUUSP, 2002 
18. CDHU - Companhia de Desenvolvimento Habitacional e Urbano. Gerência de Planejamento Econômico. [s.d.]. Disponível em: http://www.habitacao.sp.gov.br/http/indexhtm.htm. Acesso em: $1 / 12 / 2008$

19. CDHU - Companhia de Desenvolvimento Habitacional e Urbano. Gerência de Planejamento Econômico. Relatório técnico interno. São Paulo 2007

20. CDHU, SUPERINTENDÊNCIA DE ATUAÇÃO EM ÁREAS PRECÁRIAS, Relatório técnico interno São Paulo, 2003-2005

21. CDHU, SUPERINTENDÊNCIA DE PROJETOS - Gerência de Produção de Projetos de Urbanização III, Relatório técnico interno São Paulo 2006 - 2007

22. CHOAY, F. The modern city: planning in the 19th century. New York: George Brazillier, 1969

23. COELHO, A.B. Cidades sustentáveis. I - Caminhos de aprofundamento. Habitar Hoje, revista da Federação Nacional das Cooperativas de Habitação Económica (FENACHE), v. 7, n. 23, p. 19. jan. 2007

24. COELHO, W. R. O déficit das Moradias: instrumento para Avaliação e Aplicação de Programas Habitacionais, Tese (Doutorado) São Paulo: FAUUSP, 2002

25. COUTO, R.C.C.M. Eugenia, loucura e condição feminina no Brasil: as pacientes do Sanatório Pinel de Pirituba e o discurso dos médicos e dos leigos durante a década de 1930" 
Dissertação (Mestrado) São Paulo: Faculdade de Filosofia, Letras e Ciências Humanas, Universidade de São Paulo, 1994

26. DAVIS, M. Planeta Favela trad.: Beatriz Medina: São Paulo, Boitempo, 2006

27. DELLA NOCE, L. G. O Reassentamento como promotor de capital social em políticas públicas urbanas: uma análise da ação estatal em três estudos de caso Tese (Doutorado), São Paulo: FAUUSP, 2008

28. DENALDI, R. Políticas de urbanização de favelas: evolução e impasses. Tese (Doutorado), São Paulo: FAUUSP, 2003

29. Estatuto da Cidade, in Diário Oficial - Seção 1 - Atos Poder Legislativo - Edição no: 133 de $11 / 07 / 2001$

30. FABRICIO, M.M. Projeto Simultâneo na Construção de Edifícios. Tese (Doutorado) Escola Politécnica. Universidade de São Paulo, São Paulo, 2002

31. FRIEDMANN, J e LACKINGTON, T. Hyperurbanization and national Development in Chile: Some Hypotheses Urban Affairs Qartely 2, n0. 4 (June 1967): 3

32. GOVERNO DO ESTADO DE SÃO PAULO Panorama da Habitação de Interesse Social Governo do Estado de São Paulo Secretaria da Habitação/CDHU 2007/2008

33. GUERRA, A. coord. Rino Levi Arquitetura e cidade, São Paulo: Romano Guerra Editora, 2001 
34. HABITAR HOJE - Revista da FENACHE - Federação Nacional das cooperativas de habitação NUMERO 23 - ano VII Jan 2007

35. IMBRONITO, M. I. - Três edifícios para a Formaespaço: Modulares, Gemini e Protótipo Dissertação (Mestrado) São Paulo: FAUUSP, 2003

36. JÁUREGUI, J.M. Rocinha, um bairro singular: projeto de desenvolvimento sócio-espacial. [s.d.] Disponível em: http://www.jauregui.arq.br/rocinha.htm. Acesso em: 30/11/ 2008

37. KATINSKY, J.R. Casas bandeiristas: nascimento e reconhecimento da arte em São Paulo, Tese (Doutorado) São Paulo : FAUUSP, 1972

38. KROLL, L. Manifesto: lenta transformação nas políticas habitacionais. Arquitextos, n. 18, texto especial 106, nov. 2001. Disponível em: http://www.vitruvius.com.br/arquitextos/arq000/esp106.asp. Acesso em: 3/12/2008

39. YIN, R. K. Estudo de Caso Planejamento e Método trad. Daniel Grassi - 3 ed. Porto Alegre: Bookman, 2005

40. LAKATOS, E.M e MARCONI, M.A. Metodologia Científica São Paulo: Editora Atlas, 2008

41. LAMOUNIER R.F. Arquitetura e Ciência: Visões Paralelas do Mundo Contemporâneo. Caminhos para um Modelo Teórico Aplicável no Processo de Projeto. Disponível em http://www.ufmg.br/prpg/dow anais/cien soc aplic/arq urban 3/aurflamounier.doc. Acesso em: 03/02/2009 
42. LARANGEIRA, A.A. Coordenação K. Estudos estratégicos de apoio às políticas urbanas para os grupos de baixa renda no Brasil: análise de habitação informal e avaliação de programas de urbanização de favelas - Urbanização de Favelas - Avaliação Da Experiência Brasileira Sobre Urbanização De Favelas E Regularização Fundiária - CD1 - DOC09.pdf - Cities Alliance/Banco Mundial, 2005

43. LEMOS, C. A República ensina a morar (melhor) São Paulo: Editora Hucitec, 1999

44. LEMOS, C. Alvenaria Burguesa. São Paulo: Ed. Nobel, 1985

45. LEMOS, C. Cozinhas etc. São Paulo: Perspectiva, 1978

46. LEMOS, C. Arquitetura Brasileira, São Paulo: Edições Melhoramentos Editora da Universidade de São Paulo, 1979

47. LUCINI, H.C. Requalificação urbana e novos assentamentos de interesse social Tese (Doutorado) São Paulo: FAUUSP, 1996

48. LUCIO, R.L. de Construir Ciudad em la Periferia - Madrid: Mairea Libros - Escola Tecnica Superior de Arquitectura, 2007

49. MARICATO, E. in Posfácio de DAVIS, M. Planeta Favela trad. Beatriz Medina São Paulo: Boitempo, 2006

50. MCLUHAN, M. e ZINGRONE, F. Escritos esenciales Barcelona: Paidós, 1998 
51. McLUHAN, M. Os meios de comunicação como extensões do homem trad.: Décio Pignatari São Paulo: Editora Cultrix, 1974

52. MARTINEZ, A. C. Ensayo sobre el Proyeto Buenos Aires: ASPAN CP 67, 1998

53. MEYER, R. M. P. Org. São Paulo Metrópole São Paulo: Ed. da Univ. de São Paulo - Imprensa Oficial do Estado de São Paulo, 2004

54. NELSON, J. Migrants, Urban Poverty, and Instability in Developing Nations, Center for Internacional Affairs, Occasional papers in International Affairs NO 22 (Cambridge, Mass.: Harvard University, 1969)

55. OESP - O ESTADO DE SÃO PAULO, 24 fev.2008a, Caderno Imóveis, p. C12 (citado no capítulo 2)

56. PERLMAN, J. The Myth of Marginality : urban povertu and politics in Rio de Janeiro LOS Angeles: University of Carfornia Press, 1976

57. PERLMAN, J. The Methamorphosysis of marginality: the favelas of Rio de Janeiro: 1969-2002. Disponível em: http://www.worldbank.org/urban/upgrading/docs/janice-rio-restudy.pdf. Acesso em 01/02/2009

58. PASTERNAK, S. A favela que virou cidade Urban research Symposium, 2005 Disponível em: http://www.worldbank.org/urban/symposium2005/presentations/Pasternak.pdf. Acesso em $01 / 02 / 2009$ 
59. PREFEITURA MUNICIPAL DE SÃO VICENTE, SEURB, 2008

60. REIS FILHO, N. G. Imagens de vilas e cidades do Brasil Colonial São Paulo: Edusp, 2000

61. REIS FILHO, N. G. O lote urbano e a Arquitetura no Brasi, São Paulo: FAUUSP, 1969

62. REIS FILHO, N. G. Quadro da Arquitetura no Brasil São Paulo: Editora Perspectiva, $10^{\mathrm{a}}$ ed. 2004

63. REIS FILHO, N. G. São Paulo, Vila Cidade Metrópole São Paulo: Prefeitura de São Paulo, 2004

64. SAIA, L. Morada Paulista. São Paulo: Ed. Perspectiva, 1972

65. SECRETARIA DA HABITAÇÃO E DESENVOLVIMENTO URBANO DO MUNICÍPIO DE SÃO PAULO SEHAB/ COMPANHIA METROPOLITANA DE HABITAÇÃO DE SÃO PAULO - COHAB - "Balanço qualitativo de gestão 2001-2004 - Prefeitura de São Paulo, 2004

66. SEGAWA, H. Arquiteturas no Brasil 1900-1990 2a ed., São Paulo: Editora Universidade de São Paulo, 1999

67. SEgawA, H. Prelúdio da metrópole: arquitetura e urbanismo em São Paulo na passagem do século XIX ao XX. 2. ed. São Paulo: Ateliê, 2004

68. Série Mar Sem Fim: Redescobrimento da costa brasileira, São Paulo, série exibida pela TV Cultura, 04/2005-04/ 2008 
69. Silva telles, A. C. da Atlas dos Monumentos Históricos e Artísticos do Brasil Rio de Janeiro: FENAMEN/DAC, 1975

70. SILVA, J.de S. - Urbanização de Favela em área de proteção de mananciais: 0 Caso da Comunidade Sete de Setembro. Dissertação (Mestrado) São Paulo: Escola Politécnica da USP, 2003

71. SILVA, R. T - The Connectivity of Infrastrcture Network and the Urban Space of São Paulo in the 1990s - International Journal of Urban and Regional Research, Vol. 24.1 : Joint Editors and Blackwell Publishers Ltda, March, 2000

72. SILVA, R. T. Acesso a Infra-Estrutura Urbana e Desigualdades Sociais: estudo de relações com o trabalho a domícilio, São Paulo, CNPq, extrato de pesquisa, in AMARAL, P.J.A. - Perfil de necessidades e projeto de habitação. Um estudo de métodos. Tese (Doutorado) São Paulo: FAUUSP, 2005

73. SILVIA, M. V. Detritos da civilização: eugenia e as cidades no Brasil, Arquitextos 48, texto especial 245, Vitruvius, maio/ 2004

74. SOMEKH, Nadia - A cidade Vertical e o Urbanismo Modernizante São Paulo: Livros Studio Nobel, 1997

75. SOUZA, M.A. A A identidade da metrópole: a verticalização em São Paulo São Paulo: Editora Hucitec, EDUSTO, 1994 
76. TREVISAN, R. Incorporação do ideário de garden-city inglesa na urbanística moderna brasileira Estância Balneária de Águas de São Pedro. São Paulo: PPGEU/UFSCar, 2001

77. TURNER, J. e FICHTER, R.org Freedon to build London: Collier-Macmillan Limited, 1972

78. VALLADARES, L. P. Passa-se uma casa Rio de Janeiro: Zahar Editores, 1978

79. VALENTIM, L.S.O. Requalificação urbana em áreas de risco à saúde devido a contaminação do solo por substâncias perigosas: um estudo de caso na cidade de São Paulo. Dissertação (Mestrado) São Paulo: FAUUSP, 2005

80. VILARIÑO, M.C. Operação urbana: a inadequação do instrumento para a promoção de áreas em declínio Tese (Doutorado) São Paulo: FAUUSP, 2006

81. WORLD BANK GROUP. Working for a world free of poverty. 2006. Disponível em: http://siteresources.worldbank.org/EXTABOUTUS/Resources/wbgroupbrochure-en.pdf. Acesso em: $28 / 11 / 2008$

82. ZANDONADE, P. - Conjuntos habitacionais no tecido urbano da área metropolitana de São Paulo - o caso da região leste (1930/1986). Dissertação (Mestrado) São Paulo: FAUUSP, 2005 
1. BONDUKI, 1998 - Fig. 19, Fig. 28, Fig. 29, Fig. 30, Fig. 31, Fig. 32

2. COMPANHIA DE DESENVOLVIMENTO HABITACIONAL E URBANO, 2001 - Fig. 49, Fig. 75, Fig. 79, Fig. 80, Fig. 90

3. COMPANHIA DE DESENVOLVIMENTO HABITACIONAL E URBANO, 2004 - Fig. 66, Fig. 67, Fig. 68, Fig. 72, Fig. 73, Fig. 74, Fig. 76, Fig. 78, Fig. 81

4. COMPANHIA DE DESENVOLVIMENTO HABITACIONAL E URBANO, 2006 - Fig. 43, Fig. 44, Fig. 45, Fig. 58, Fig. 59, Fig. 60, Fig. 61, Fig. 62

5. COMPANHIA DE DESENVOLVIMENTO HABITACIONAL E URBANO, 2007 - Fig. 43, Fig. 91, Fig. 92, Fig. 93, Fig. 94, Fig. 95, Fig. 96, Fig. 97, Fig. 98, Fig. 99, Fig. 100, Fig. 101, Fig. 102, Fig. 103, Fig. 104, Fig. 105, Fig. 106, Fig. 107, Fig. 108, Fig. 109, Fig. 110, Fig. 111, Fig. 112, Fig. 113, Fig. 114, Fig. 115, Fig. 116, Fig. 119, Fig. 120, Fig. 121, Fig. 122

6. GOOGLE, 2008 - Fig. 82, Fig. 85

7. IMBROLITO, 2004 - Fig. 39, Fig. 40, Fig. 41

8. INFORME PUBLICITÁRIO, 2008 - Fig. 50, Fig. 51, Fig. 52

9. JORGE MARIO JAUREGUI, S/D - Fig. 121, Fig. 122

10. JUAN VILÀ, 2003 - Fig. 63, Fig. 64, Fig. 69, Fig. 70

11. LEMOS, 1978 - Fig. 2, Fig. 26 
12. LEMOS, 1985 - Fig. 4, Fig. 5, Fig. 6, Fig. 7

13. LEMOS, 1999 - Fig. 20, Fig. 21, Fig. 22, Fig. 33

14. MEYER, 2004 - Fig. 46, Fig. 47, Fig. 48, Fig. 65

15. MINHA CASA MEU IMÓVEL, 2007/2008 - Fig. 53, Fig. 54, Fig. 55, Fig. 56, Fig. 57

16. PAULO BASTOS, 2008 - Fig. 71

17. PREFEITURA MUNICIPAL DE SÃO PAULO (PMSP), 1999 - Fig. 42

18. PREFEITURA MUNICIPAL DE SÃO VICENTE (PMSV), 2007/2008 - Fig. 86, Fig. 87, Fig. 88, Fig. 89, Fig. 117, Fig. 118, Fig. 120, Fig. 121

19. PROJETODESIGN, 2006 - Fig. 77

20. REIS, 2004 - Fig. 1

21. REIS, 2004 - Fig. 8

22. SEGALL, LASAR - Paisagem Brasileira, 1925 - capa

23. SEGAWA, 2004 - Fig. 9, Fig. 10, Fig. 11, Fig. 12, Fig. 13, Fig. 14, Fig. 15, Fig. 16, Fig. 17, Fig. 18, Fig. 23. Fig. 24, Fig. 25, Fig. 27, Fig. 34, Fig. 35, Fig. 36, Fig. 37, Fig. 38 


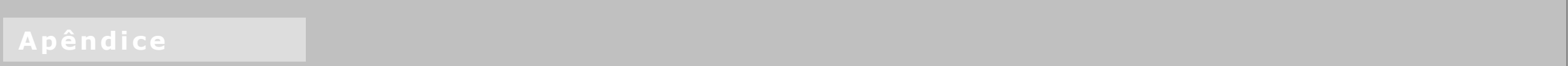

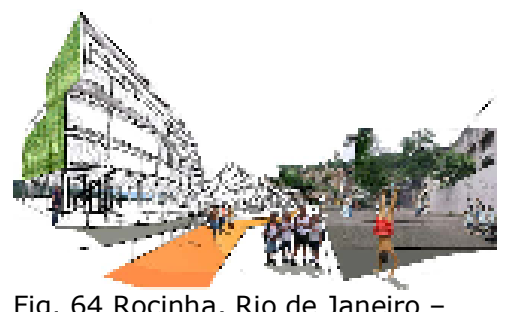

Fig. 64 Rocinha, Rio de Janeiro Pólo Educacional (JÁUREGUI)

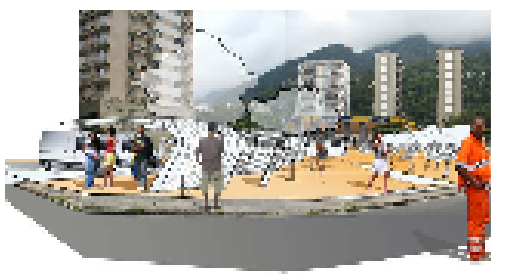

Fig. 65 Rocinha - Terminal de Kombis (JÁUREGUI).

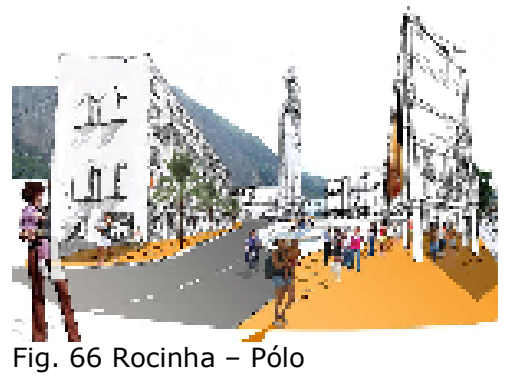

comunicacional, espaço interior (JÁUREGUI)

\section{Rocinha: um bairro singular \\ Projeto de desenvolvimento sócio-espacial}

"Do nosso ponto de vista, trata-se da questão da articulação dos aspetos físicos (urbanísticos, infraestruturais e ambientais), sociais (econômicos, culturais e existenciais), ecológicos (considerando as três ecologias: mental, social e ambiental) e os relativos à segurança do cidadão, visando o desenvolvimento local, desde uma concepção sócio-espacial de territórios produtivos, levando em conta as excepcionais condições de contexto. Isto é, a sua localização em relação aos bairros vizinhos da Gávea-Leblon e São Conrado, o que estabelece uma situação muito particular de inclusão-exclusão. Assim, se de um lado as condições da 'acessibilidade' são boas, de outro o sistema viário existente é absolutamente insuficiente, ineficiente e restritivo. Portanto, a reconfiguração do traçado viário de um lado, e a reformulação do sistema de transporte público do outro, são medidas estruturais básicas.

Do mesmo modo, com toda a força do comércio local, especialmente em Bairro Barcelos, sua desordem e falta de qualidade desperdiçam um grande potencial de configurar-se em irradiador de urbanidade e atrator de uma muito maior clientela externa. Isto, junto com a necessidade de criação de um novo pólo de geração de trabalho e renda, a partir das características específicas da mão de obra local, permitindo desenvolver o potencial do capital humano.

A falta de escola de segundo grau e centro profissionalizante constitui outra das carências marcantes que freiam o desenvolvimento local. O mesmo se verifica em relação à falta de equipamentos culturais e comunicacionais, sendo uma demanda específica das três associações de moradores. 


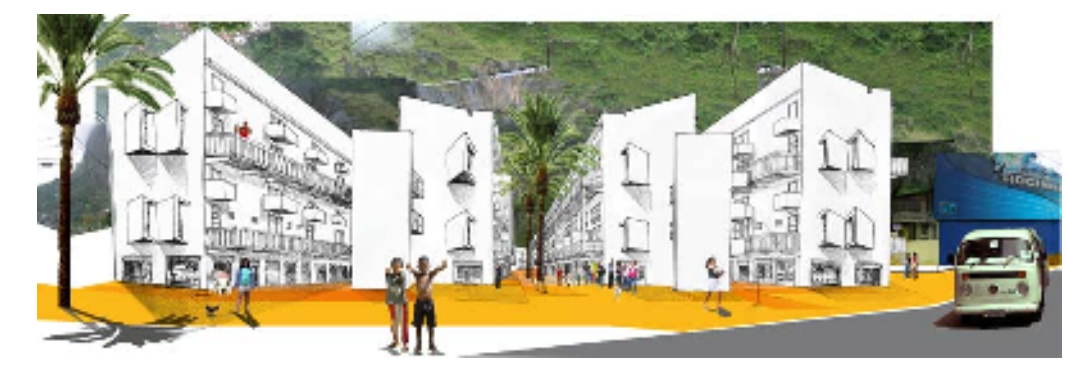

Fig. 67 - Rocinha, Rio de Janeiro - Pólo de geração de trabalho e renda - Lazer (JÁUREGUI)

A falta de um centro de saúde à escala da comunidade para atender os graves problemas dos moradores, junto com os problemas dos sistemas de drenagem, obstrução de valões, insuficiência de sistemas de esgotos, de distribuição de água, da precariedade do sistema de vias de circulação interna, do descontrole da expansão e da demanda habitacional, completam o quadro da situação. 

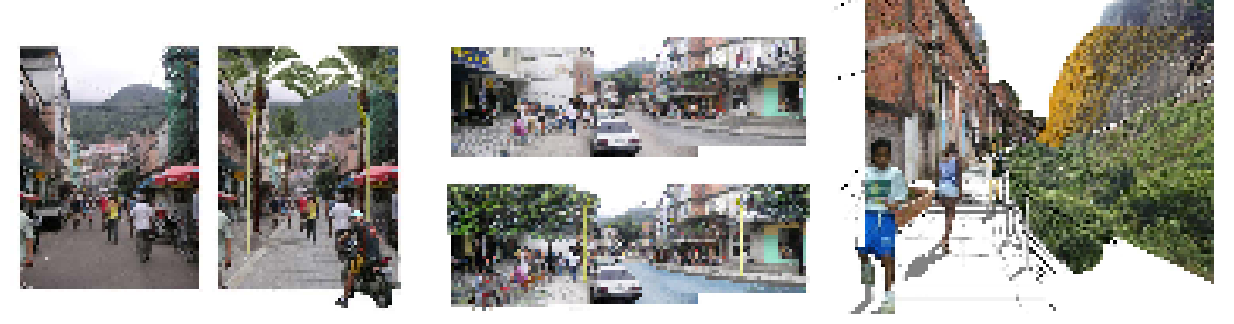

Figs. 68, 69 e 70 - Rocinha, Rio de Janeiro - Urbanização da via Ápia; urbanização da estrada da Gávea; Ecolimites

Partindo da leitura da estrutura do lugar, da escuta das demandas da população e de uma clara conceituação da questão da articulação do formal e do informal, a estratégia projetual elaborada concebida como um Sistema Inteligente de Conectividades e Interfaces articula em sucessivas etapas os quatros aspectos inicialmente considerados, estabelecendo uma hierarquia estruturadora sócioespacial.

A noção de territórios produtivos e o direito à urbanidade fundamentam a proposta de reestruturação sócio-espacial, baseada numa hierarquia de pólos, centros e células de planejamento urbano que buscam reterritorializar e desestratificar o lugar. Hoje a luta é contra a informalidade da cidade em geral e não só da favela. Por isso, trata-se de pensar a lógica cultural necessária para transformar a subjetividade, indo de sujeitos excluídos da urbanidade a agentes de transformação. É necessário pensar em novos dispositivos destinados a fazer cooperar, em projetos eficazes e pactuados, 
programas públicos e privados relacionados com novos tipos de hábitats e usos para segmentos populacionais múltiplos. Hoje é necessário definir na dissolução, operar 'entre'." (JÁUREGUI, [s.d.]) 